\title{
Archeological Survey and Testing of Selected Prehistoric Sites along FM 481, Zavala County, Texas
}

\author{
Raymond P. Mauldin \\ Center for Archeological Research, University of Texas at San Antonio \\ Bruce K. Moses \\ Russell D. Greaves \\ Steve A. Tomka \\ Raba Kistner \\ J. Philip Dering
}

See next page for additional authors

Follow this and additional works at: https://scholarworks.sfasu.edu/ita

Part of the American Material Culture Commons, Archaeological Anthropology Commons, Environmental Studies Commons, Other American Studies Commons, Other Arts and Humanities Commons, Other History of Art, Architecture, and Archaeology Commons, and the United States History Commons

Tell us how this article helped you.

This Article is brought to you for free and open access by the Center for Regional Heritage Research at SFA ScholarWorks. It has been accepted for inclusion in Index of Texas Archaeology: Open Access Gray Literature from the Lone Star State by an authorized editor of SFA ScholarWorks. For more information, please contact cdsscholarworks@sfasu.edu. 


\title{
Archeological Survey and Testing of Selected Prehistoric Sites along FM 481, Zavala County, Texas
}

\author{
Authors \\ Raymond P. Mauldin, Bruce K. Moses, Russell D. Greaves, Steve A. Tomka, J. Philip Dering, and Jason D. \\ Wetson

\section{Licensing Statement} \\ This is a work produced for the Texas Department of Transportation (TxDOT) by the report producer. \\ TxDOT and the report producer jointly own all rights, title, and interest in and to all intellectual property \\ developed under TXDOT's contract with the report producer. The report may be cited and brief passages \\ from this publication may be reproduced without permission provided that credit is given to both TxDOT \\ and the report producer. Permission to reprint an entire chapter, section, figures or tables must be \\ obtained in advance from either the Supervisor of the Archeological Studies Branch, Environmental \\ Affairs Division, Texas Department of Transportation, 125 East 11th Street, Austin, Texas, 78701 or from \\ the report producer.
}




\section{Archeological Survey and Testing of Selected Prehistoric Sites along FM 481 , Zavala County, Texas}

Raymond P. Mauldin, Bruce K. Moses, Russell D. Greaves, Steve A. Tomka, J. Philip Dering, and Jason D. Weston

Work Authorization No. 57015 PD004 Contract No. 570 XX PD004

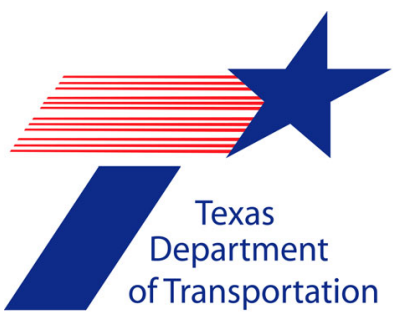

Environmental Affairs Division

Texas Department of Transportation Archeological Studies Program, Report No. 67

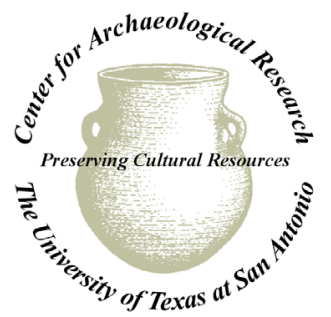

Center for Archaeological Research The University of Texas at San Antonio Archaeological Survey Report, No. 352 


\title{
Archeological Survey and Testing of Selected Prehistoric Sites along FM 481, Zavala County, Texas
}

\author{
by \\ Raymond P. Mauldin, Bruce K. Moses, Russell D. Greaves, \\ Steve A. Tomka, J. Philip Dering, and Jason D. Weston
}

\section{Raymond P. Mauldin \\ Principal Investigator}

\section{Work Authorization No. 57015 PD004}

Contract No. 570 XX PD004

Prepared for:

Environmental Affairs Division

Texas Department of Transportation

Archeological Studies Program, Report No. 67

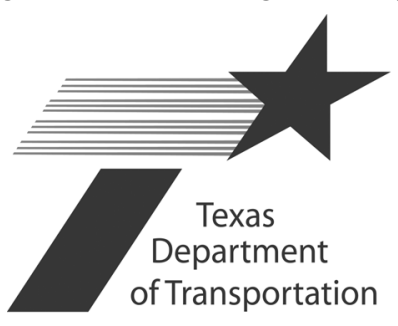

Prepared by:

Center for Archaeological Research The University of Texas at San Antonio Archaeological Survey Report, No. 352

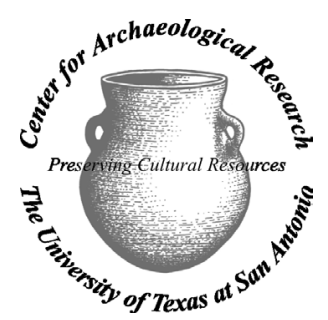




\title{
Archeological Survey and Testing of Selected Prehistoric Sites along FM 481, Zavala County, Texas
}

\author{
Copyright ${ }^{\left({ }^{2}\right.} 2004$ \\ Texas Department of Transportation (TxDOT) and Center for Archaeological Research, \\ The University of Texas at San Antonio (CAR-UTSA)
}

\begin{abstract}
All rights reserved
TxDOT and CAR-UTSA jointly own all rights, title, and interest in and to all data and other information developed for this project under Contract 570XXPD004. Brief passages from this publication may be reproduced without permission provided that credit is given to TxDOT and CAR-UTSA. Permission to reprint an entire chapter, section, figures or tables must be obtained in advance from the Supervisor of the Archeological Studies Program, Environmental Affairs Division, Texas Department of Transportation, 125 East 11th Street, Austin, 78701. Copies of this publication have been deposited with the Texas State Library in compliance with the State Depository requirements.
\end{abstract}

Printed by Kwik Kopy Printing on Main, San Antonio

2004

jointly published by

Texas Department of Transportation

Environmental Affairs Division

Archeological Studies Program

Owen Lindauer, Ph.D., Supervisor

Archeological Studies Program, Report No. 67

A. McGraw, Series Editor

and

Center for Archaeological Research

The University of Texas at San Antonio

Archaeological Survey Report, No. 352 


\section{Abstract:}

Between April 1981 and December 1982, Texas Department of Transportation (TxDOT) personnel conducted archeological fieldwork along an approximately 13-km segment of FM 481 in northwest Zavala County. The work was part of an evaluation of the impacts of road improvements to a series of sites along the right-of-way. All of the sites but one (41ZV202) were found not to be eligible for listing on the National Register of Historic Places and not to warrant designations as State Archeological Landmarks. Additional work, not reported here, was later conducted at 41ZV202. As part of Work Authorization \#57015PD004, the Environmental Affairs Division of TxDOT contracted with the Center for Archaeological Research (CAR) of The University of Texas at San Antonio to report on the fieldwork carried out at the sites during the early 1980s, identify data types warranting additional research, and conduct the appropriate analyses. The current document provides descriptions of the work undertaken along FM 481, assesses the analytical utility of the data types recovered, and reports the results of limited new research of selected data types. Note that all documentation of the project, including notes, photographs, and a sample of recovered artifacts are curated at the Center for Archaeological Research. The sample includes all projectile points, as well as other chipped and ground stone tools, and the debitage recovered for a $10 \%$ sample of proveniences. 


\section{Table of Contents:}

Abstract

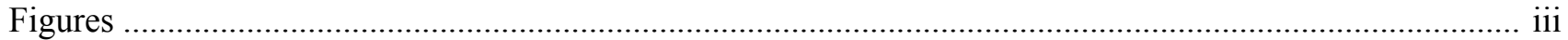

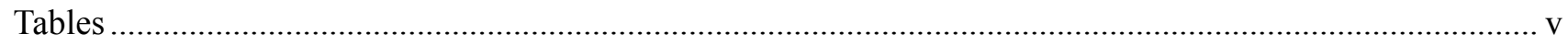

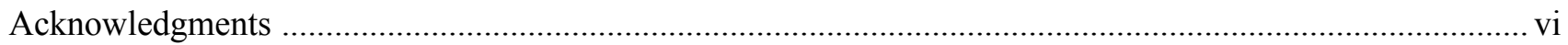

Chapter 1: Project Overview by Raymond P. Mauldin, Bruce K. Moses, and Russell D. Greaves

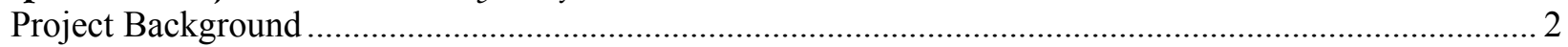

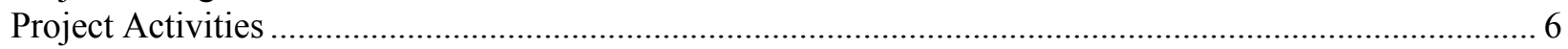

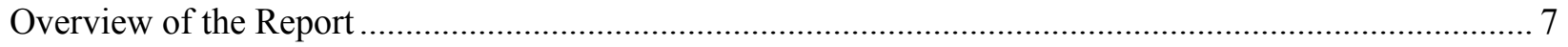

Chapter 2: Environmental Setting by Raymond P. Mauldin

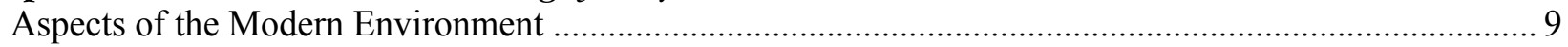

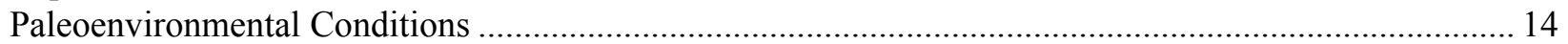

Chapter 3: Archeological Setting by Raymond P. Mauldin and Bruce K. Moses

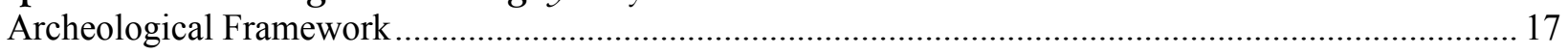

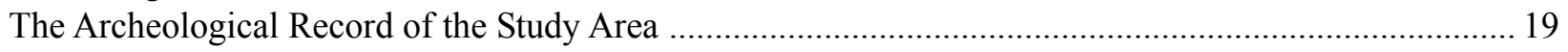

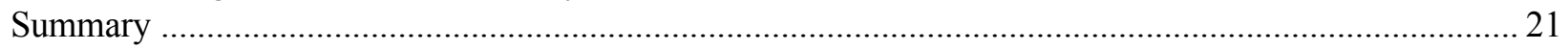

Chapter 4: Archeological Methods and Site Descriptions by Bruce K. Moses, Russell D. Greaves, Raymond P. Mauldin, and Jason D. Weston

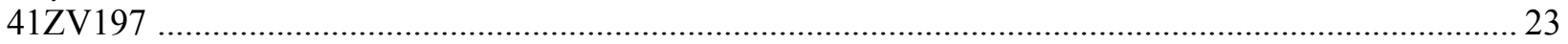

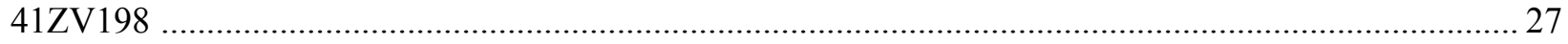

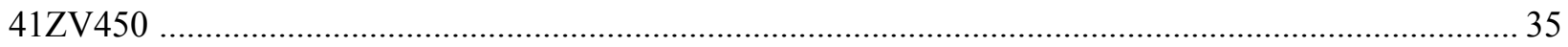

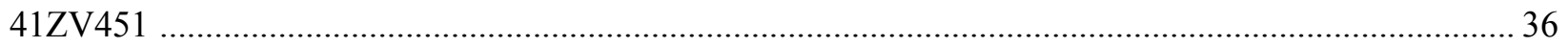

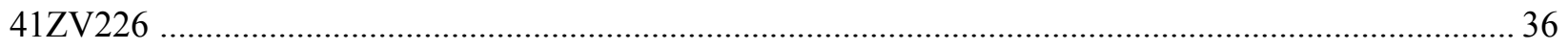

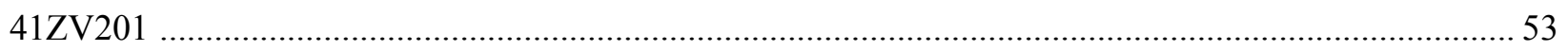

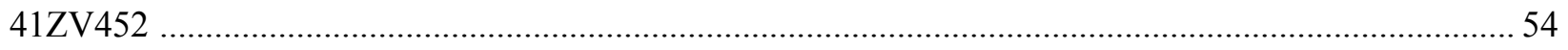

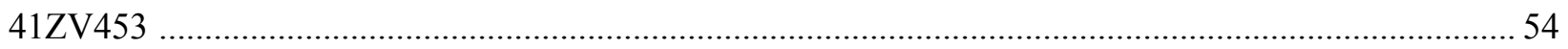

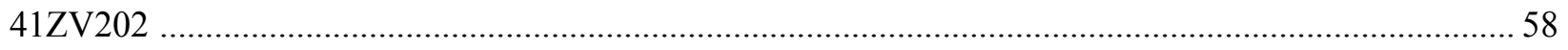

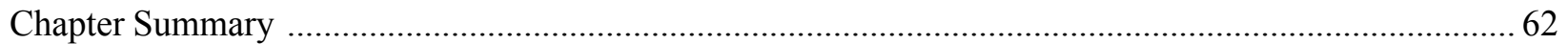

Chapter 5: Research Directions and Results by Raymond P. Mauldin, J. Philip Dering, and

Steve A. Tomka

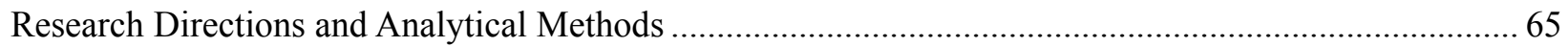

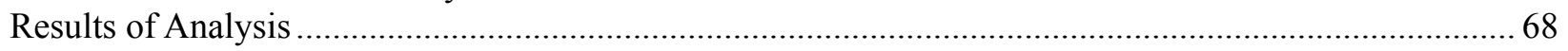

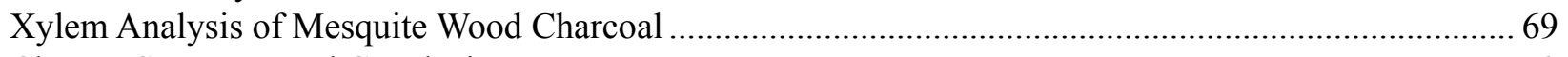

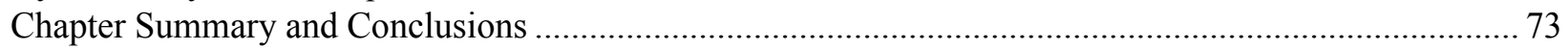

Chapter 6: Summary by Raymond P. Mauldin and Russell D. Greaves

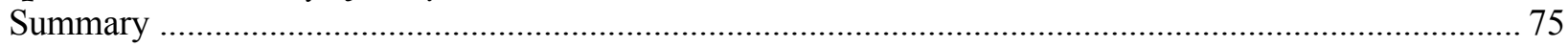

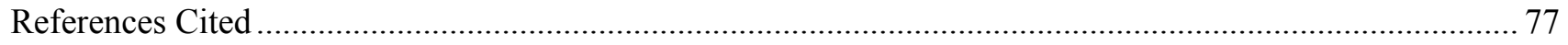

Appendix A: Radiocarbon Results
Radiocarbon Results 


\section{Figures:}

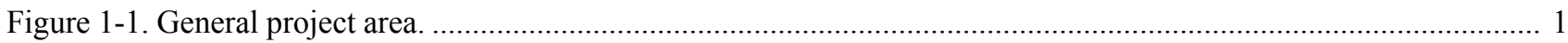

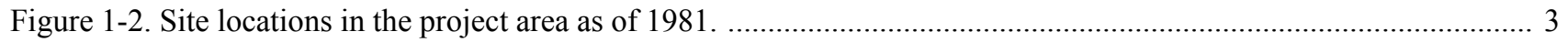

Figure 1-3. Site locations in the project area based on the 1982 investigations and the 2002 sites assessment document. . 4

Figure 1-4. Site locations in the project area based on Houk et al. 2003. ................................................................... 5

Figure 2-1. Average monthly temperature at Uvalde, Texas, 1971-2000 .............................................................. 10

Figure 2-2. Average monthly precipitation at Uvalde, Texas, 1971-2000. .............................................................. 10

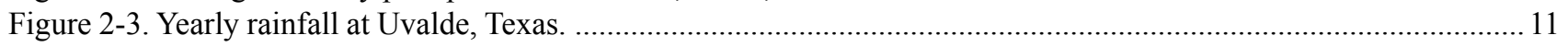

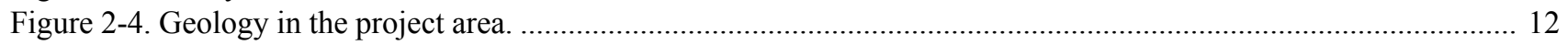

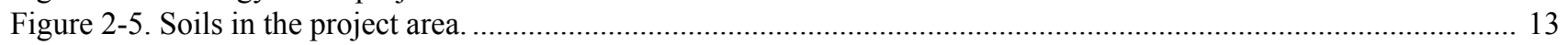

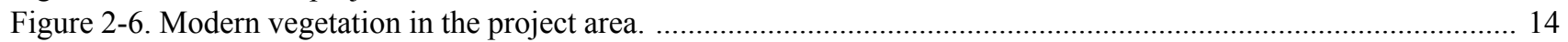

Figure 3-1. Location of the Chaparrosa Ranch and East Chacon archeological projects.............................................. 20

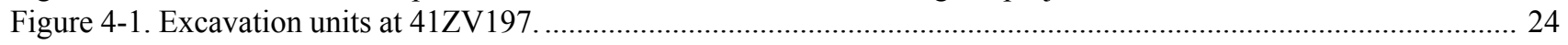

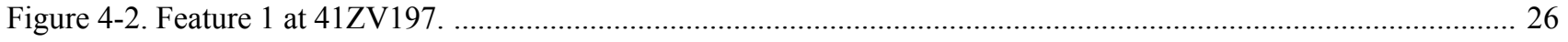

Figure 4-3. Average number of debitage recovered per excavated level at 41ZV197. ................................................. 26

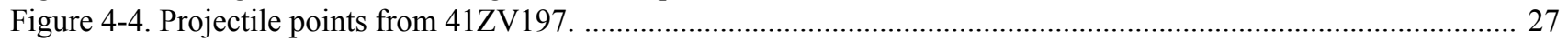

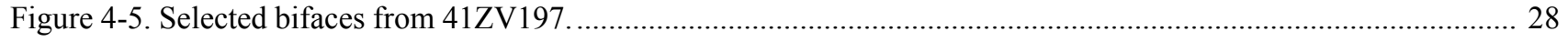

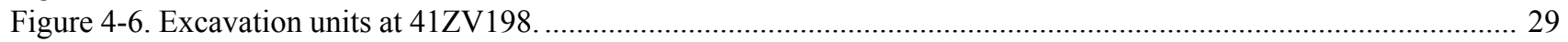

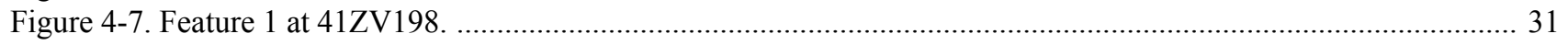

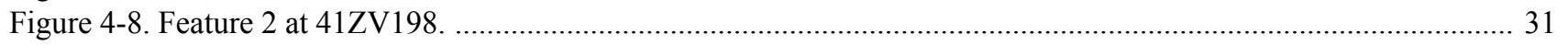

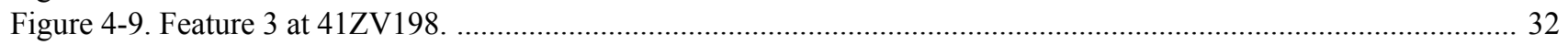

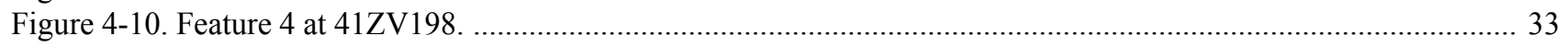

Figure 4-11. Average number of debitage recovered per excavated level at 41ZV198. ............................................... 33

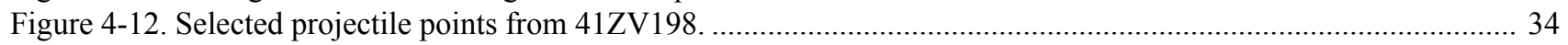

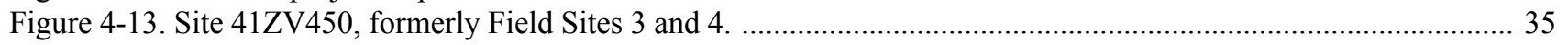

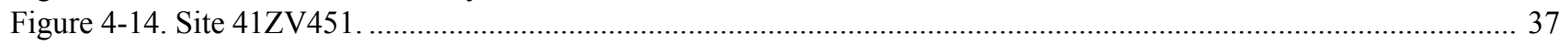

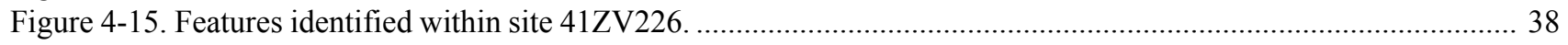

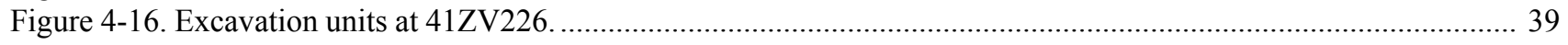

Figure 4-17. Feature distribution and unit along FM 481, site 41ZV226............................................................... 41

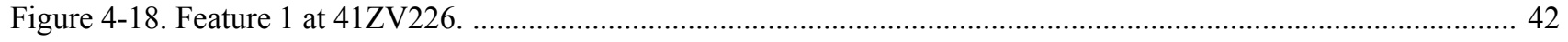

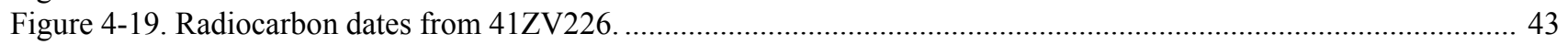

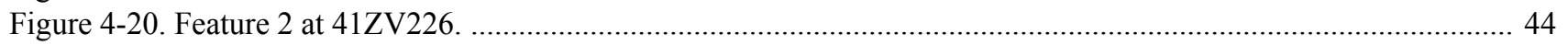

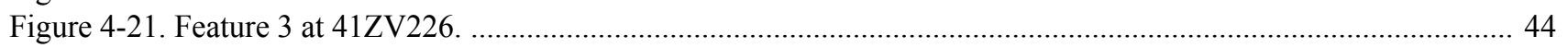

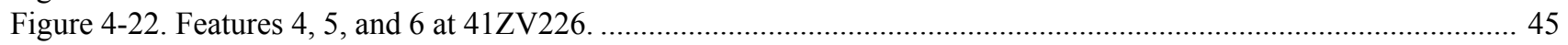

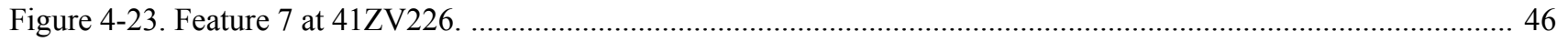

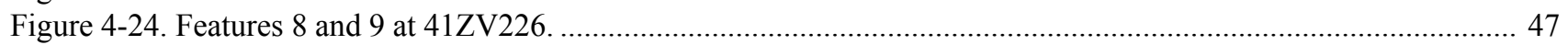

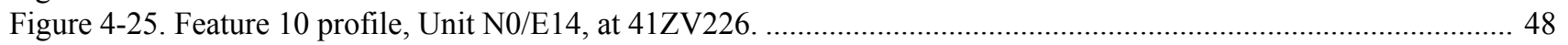

Figure 4-26. Profile of Units N0/E6 and N2/E6 at 41ZV226................................................................................ 48

Figure 4-27. Average number of debitage recovered per excavated level at 41ZV226............................................... 49

Figure 4-28. Selected arrow points recovered from 41ZV226. ............................................................................ 50

Figure 4-29. Selected dart points recovered from 41ZV226. .............................................................................. 51

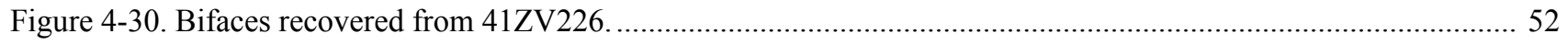

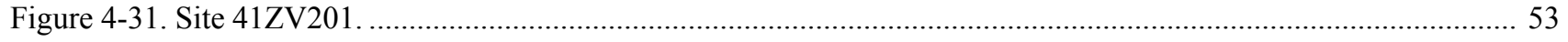

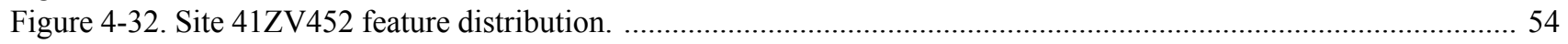

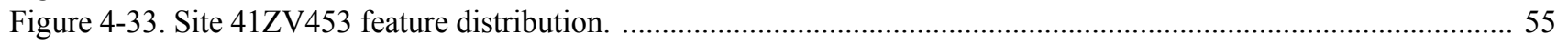

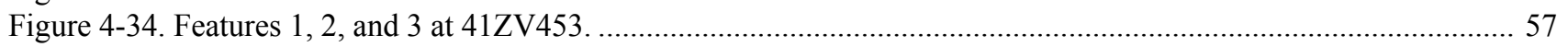

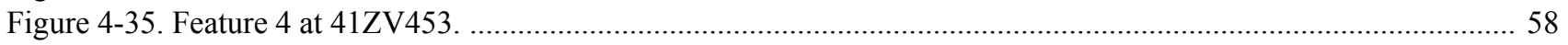

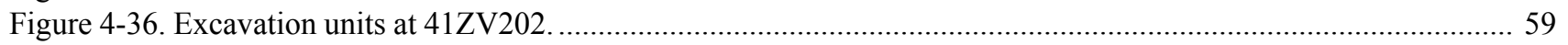


Figure 4-37. Test Pits 3 through 6, and coyote burial pits 1 and 2, at 41ZV202. ................................................... 60

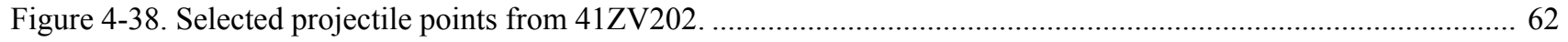

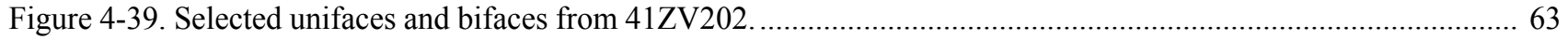

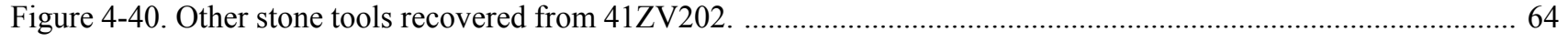




\section{Tables:}

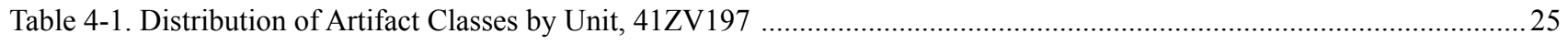

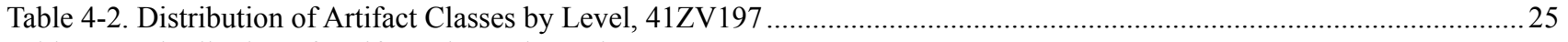

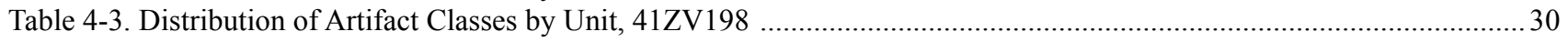

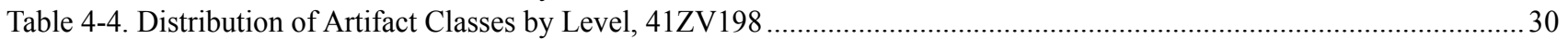

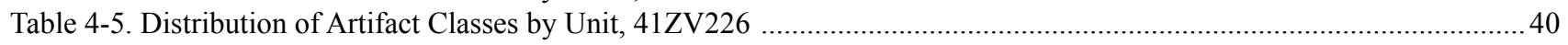

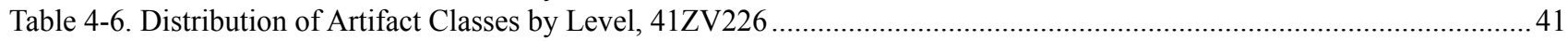

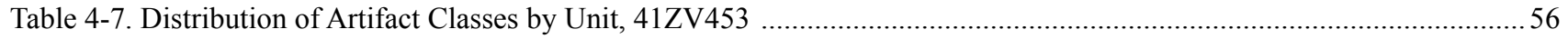

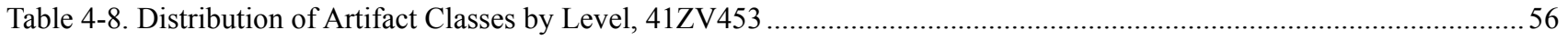

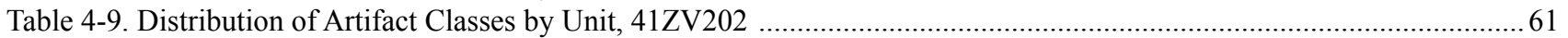

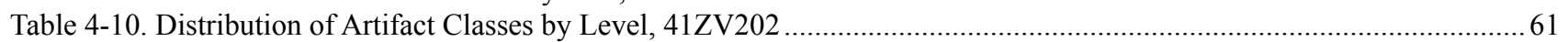

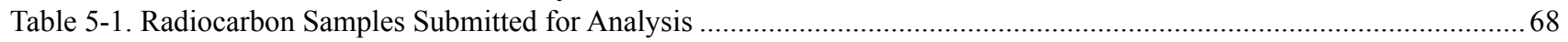

Table 5-2. Radiocarbon Dates on Paired Samples from Sites 41ZV198 and 41ZV226 .................................................. 70

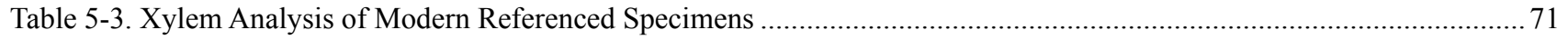

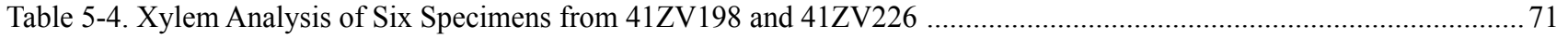

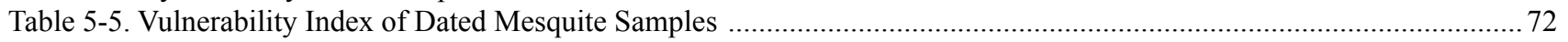




\section{Acknowledgments:}

Several people, both at the Archeology Studies Program of the Environmental Affairs Division at TxDOT in Austin, and at the Center for Archaeological Research, were instrumental in the completion of this project. Specifically, thanks go to Nancy Kenmotsu, Owen Lindauer, Jim Abbot, Tim Mead and Maureen Brown. Tim Mead, who is no longer at TxDOT, provided initial oversight on the project and both Tim and Jim helped in a variety of ways. Thanks are also extended to Al McGraw and Jim Abbott for constructive comments provided during their review of the draft report. At CAR, special thanks go to the laboratory staff, as well as Rick Young and Bruce Moses in the graphics department. These individuals spent a great deal of time studying the array of proveniences and maps that were generated at a time when several of them were not yet born. Bruce Moses deserves special thanks. It was Bruce who figured out the utility of the transit maps that were critical in precisely relocating the sites that were documented in the early 1980s along FM 481. Thanks also go to Johanna Hunziker, CAR editor, who skillfully polished an earlier draft of this manuscript and saw it through layout and printing. 


\section{Chapter 1: Project Overview}

\section{Raymond P. Mauldin, Bruce K. Moses, and Russell D. Greaves}

This report presents the results of fieldwork conducted by the Texas Department of Transportation (TxDOT) between 1981 and 1982 as part of an evaluation of the impacts of road improvements to FM 481 in northwest Zavala County, Texas (Figure 1-1). Daymond Crawford and Jerry Henderson oversaw the fieldwork during which a number of archeological sites were documented and tested. Based on this work, it was determined that all but one site were not eligible to the National Register of Historic Places (NRHP) and did not warrant designation as State Archeological Landmarks (SAL). The eligibility status of one site (41ZV202) remained unknown until it was tested in 2002.

In August of 2002, TxDOT issued Work Authorization \#57015PD004 to the Center for Archaeological Research (CAR) at The University of Texas at San Antonio to report on the 1981-1982 work conducted by TxDOT along FM 481 and to provide an assessment of existing records, artifacts, and specialized samples from six prehistoric archeological sites (41ZV197, 41ZV198, 41ZV201, 41ZV202, 41ZV203 and 41ZV226) that TxDOT was thought to have tested. The primary purpose of the assessment was to identify the existing documentary information, curate the artifacts and records from fieldwork, and determine what research questions of archeological interest may be addressed with the extant records and recovered materials.

The assessment document was completed in December of 2002 (Greaves et al. n.d.). The review of the extant records performed during the assessment actually suggested that some level of effort, either mapping or excavation, was

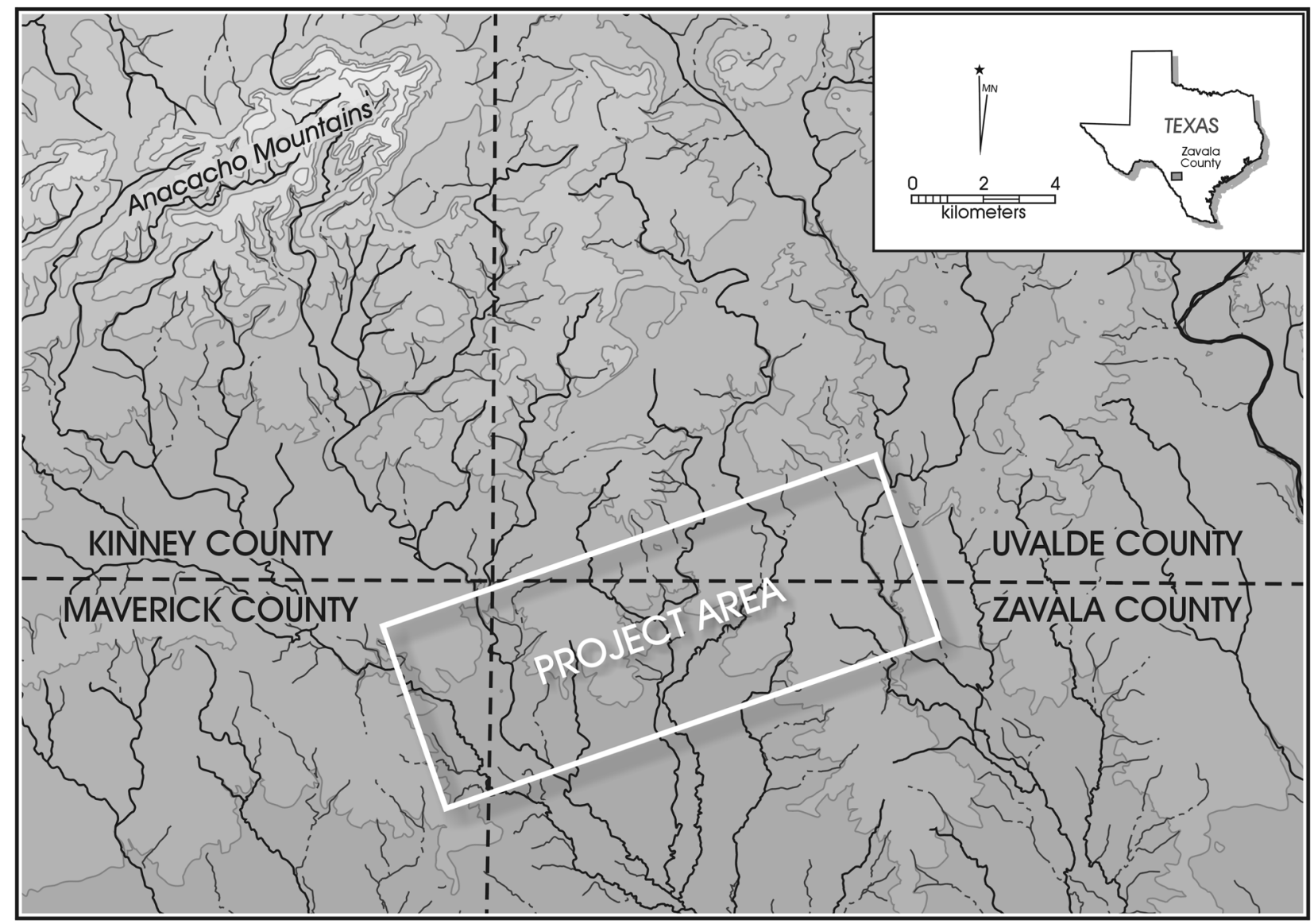

Figure 1-1. General project area. 
conducted by TxDOT personnel at 11 different sites. In addition, several of the sites lacked trinomial numbers. As requested in the scope of work, the assessment document also outlined two general research domains that could be addressed with a limited set of data from selected sites. The first research domain dealt with aspects of lithic technology and changes in that technology through time, while the second dealt with paleoenvironmental research focused on dated mesquite charcoal. In August of 2003, TxDOT agreed to pursue the research domains outlined in the assessment document. The current report, and the analysis discussed herein, was developed under Work Authorization \#57015PD004, the same Work Authorization that covered the assessment. Additional tasks under that Work Authorization included the preparation for curation of all records and documents associated with the FM 481 investigations, as well as all tools and cores, and debitage from a $10 \%$ random sample of each provenience.

\section{Project Background}

The history of site designations is complex. Daymond Crawford performed the initial survey of sites along FM 481 in 1981. He identified seven sites along the Zavala County portion of FM 481. Moving from east to west, these were 41ZV197, 41ZV198, 41ZV199, 41ZV200, 41ZV201, 41ZV202, and 41ZV203. An eighth site, 41ZV226, was recorded in December of 1981 by Jerry Henderson. Figure 1-2 presents the trinomial site distribution as recorded by Crawford and Henderson in 1981 (Henderson 1981, 1982).

Testing began in October of 1981 at 41ZV202, but the project was suspended in November of 1981. Testing was resumed in July of 1982 and continued through September of 1982. The 1982 testing was an emergency effort, performed rapidly in response to informal notice that highway improvements were being performed along FM 481. Records of the testing effort identify sites $41 Z V 197$, 41ZV198, 41ZV201, 41ZV202, 41ZV203A, and 41ZV226 as having some level of testing performed. Henderson informally designated a tested area as site $41 \mathrm{ZV} 203 \mathrm{~A}$ as she thought the site was close to site 41ZV203 (Figure 1-3), but no trinomial number was ever assigned to that site location. In addition, testing and mapping of a "hearth field," which was thought by Henderson to be between sites 41ZV226 and 41ZV201, was conducted (Figure 1-3).

Woody Wooldridge, of TxDOT, mapped the hearth field in late September of 1982. The hearth field transit maps contain information on 124 features along with the highway's rightof-way, stationing information, and some excavation units. Using a variety of data, including the hearth field maps, station markers, aerial photos, and Henderson's site notes, Greaves et al. (n.d.) argue that site 41ZV226 was incorrectly plotted in the Texas Archeological Sites Atlas. Henderson recorded the location of 41ZV226 as being between 41ZV201 and 41ZV203, when the highway stationing information places the site between 41ZV199 and 41ZV198 (see Figures 1-2 and 1-3). The work conducted by Henderson to the east of 41ZV226 was, then, not moving towards $41 Z V 201$, but well east of it. Greaves et al. (n.d.) suggest that no testing was actually conducted on site 41ZV201, as this site was to the west of the hearth field, not to the east. The area that Henderson documented as 41ZV201 in 1982 is approximately 4,900 meters east of the plotted location of 41ZV201 identified by Crawford. This scenario is further supported by the designation of a previously unrecorded site by Henderson as 41ZV203A, a designation made because she believed the unrecorded site was "closest" to 41ZV203 (see Figure 1-3). The location of 41ZV203A, using the station information, is roughly 960 meters to the east of site 41ZV203 (Greaves et al. n.d.). Based on the station location for this site, 41ZV203A was abutting the western edge of where Henderson designated site 41ZV226 for the Texas Archeological Sites Atlas. As Greaves et al. (n.d.:8) note, "Only if she had incorrectly located site $41 Z V 226$, well to the west of the actual location, would she have made such a designation."

Based on the transit maps, 14 sites can be identified along this highway segment. No excavation or map data existed for sites 41ZV199, 41ZV200, and 41ZV203, and they are not discussed any further in this report. In an effort to reduce confusion, the assessment document identified the remaining 11 sites with field site (FS) numbers, moving from east to west (Figure 1-4). Of these, six (FS 3, 4, 5, 7, and 9, and FS 10 originally designated by Henderson as 41ZV203A) are new sites that lacked trinomials at the time of the writing of the assessment document. Four other field sites, FS 1, 2, 8, and 11, were originally designated by Crawford as 41ZV197, 41ZV198, 41ZV201, and 41ZV202, respectively. Finally, the eleventh site, FS 6 (41ZV226), was the site designated by Henderson in 1982 (Figure 1-4).

Greaves et al. (n.d.) identified the eastern location of 41ZV226 shown in Figure 1-4 on the basis of the hearth field map. They assumed, following Henderson's statements, that 41ZV226 was located just to the west of the excavation that she thought was being conducted between 41ZV226 


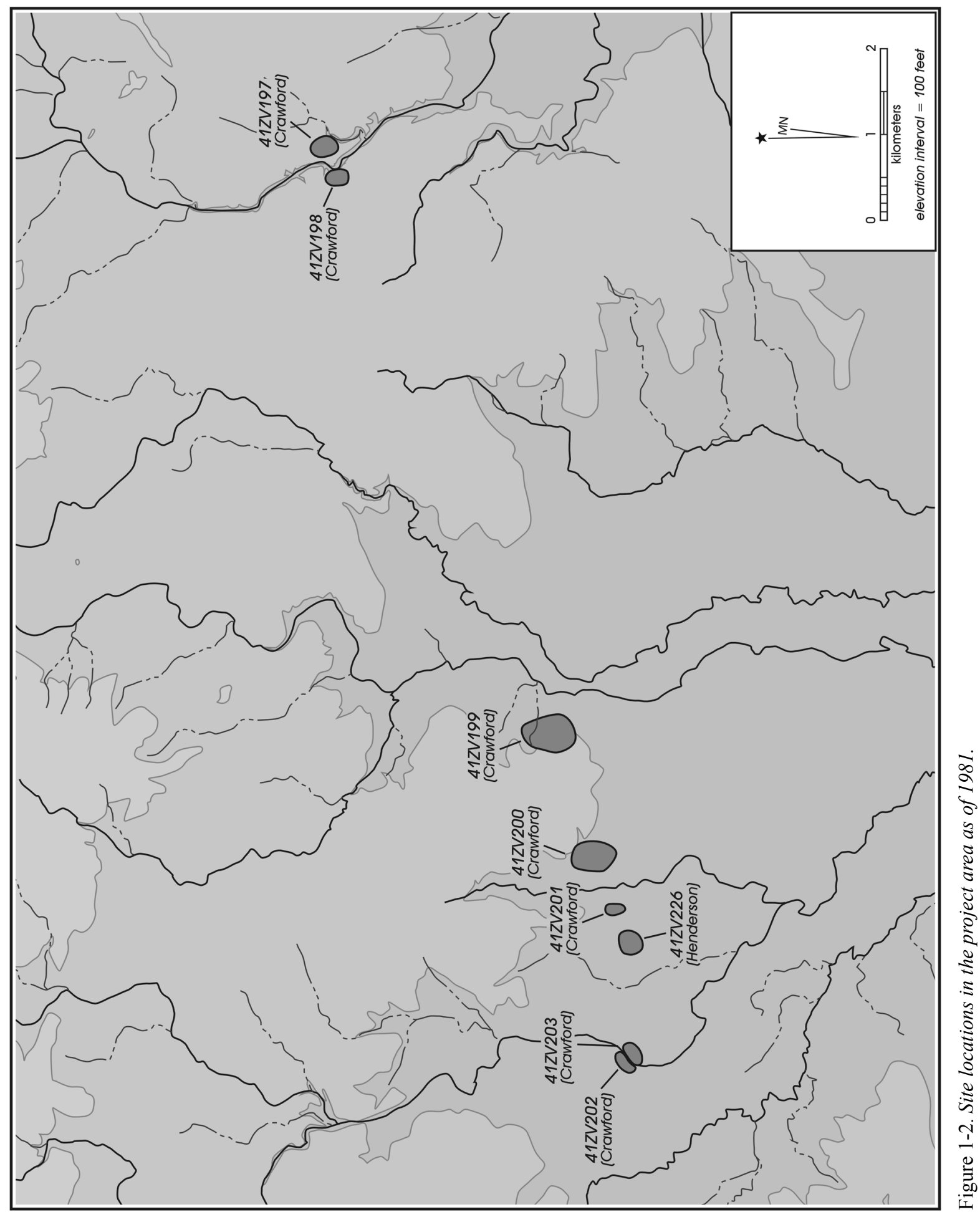




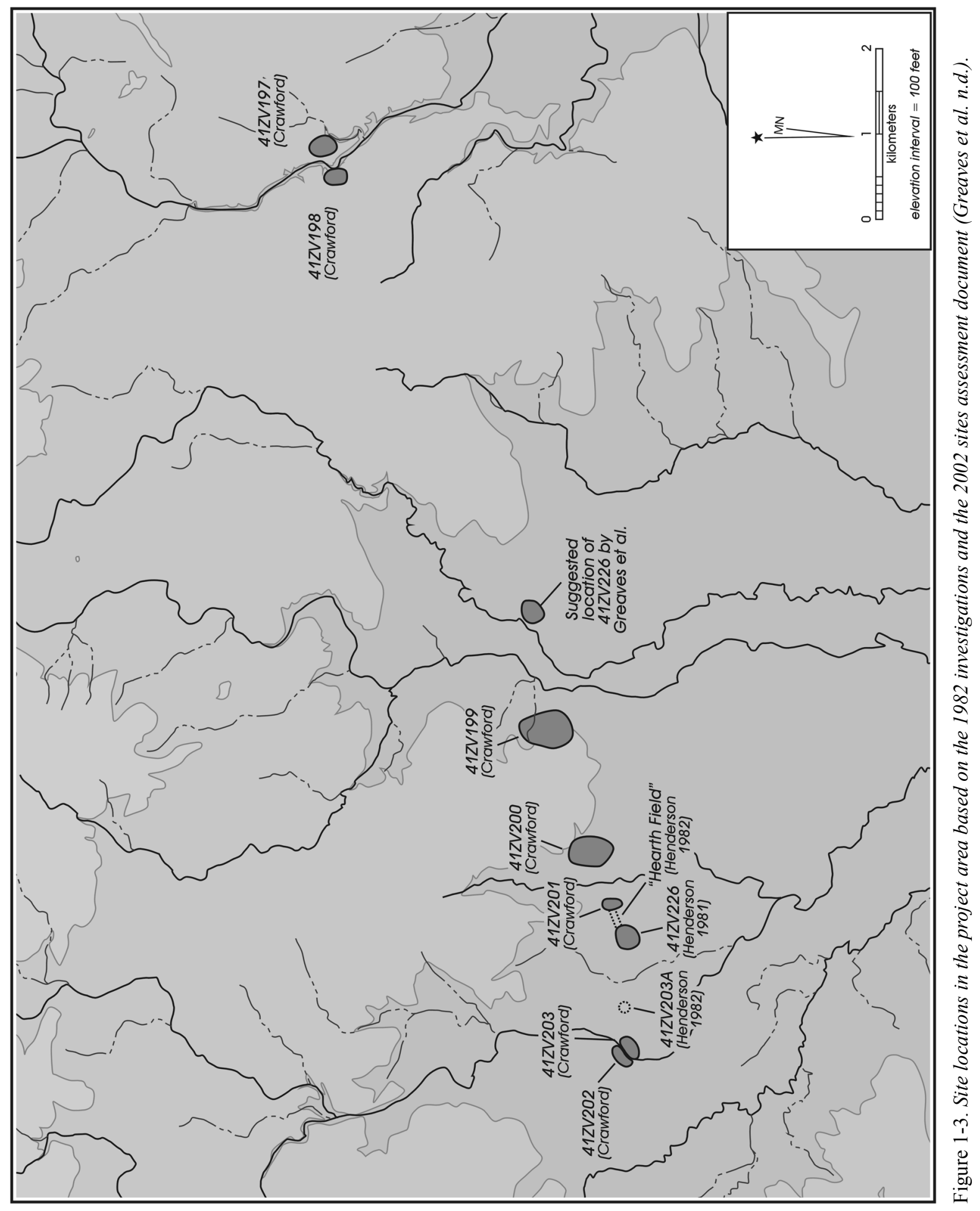




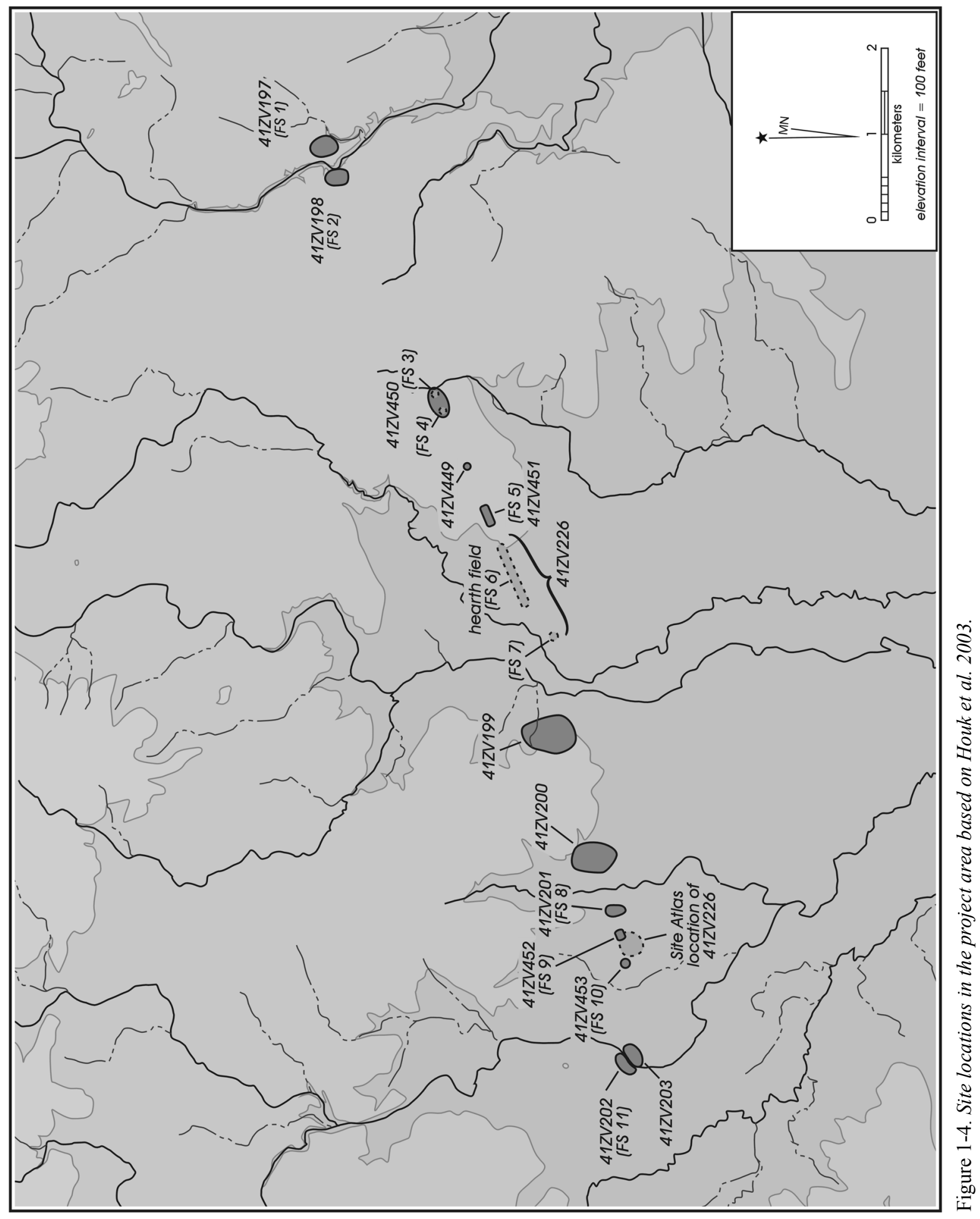


and 41ZV201 (Henderson 1982). This assumption would mean that Henderson's original 1981 plotting of the site was incorrect. There is, however, another, and we believe more probable, explanation. That explanation is that Henderson's erroneous location of site 41ZV226 occurred in 1982, not 1981. This argument is based on several elements in Henderson's original 1981 site survey form. In 1981 Henderson notes the location of 41ZV226 as " 1.1 miles east of the Zavala/Maverick County line, at an intersection of the east-west county road (which is an extension of R. M. 481) and a north-south ranch road, just north of the entrance gate to the Gato Ranch.” The location plotted by Henderson on the quadrangle map contains all these elements, and in 2002 there was a sign identifying the "Gato Ranch" at this location. In contrast, the modified placement of 41ZV226 between sites 41ZV199 and 41ZV198 (Greaves et al. n.d.) contains none of these elements. Most telling is the lack of a north-south road, a feature unlikely to be misidentified. In addition, the modified plot is over 3.7 miles from the county line. As discussed previously, the modified plotting relied on Henderson's 1982 notes and the hearth field location. There is no doubt that the hearth field location in Figure 1-4 is correct. Nor is there any doubt that Henderson assumed, in 1982, that she was between 41ZV226 and 41ZV201. We now suggest that it was in making this assumption that Henderson was in error. Site 41ZV226 is probably just were Henderson said it was in 1981, and the "hearth field" is where the transit maps place the location. It is likely, then, that the hearth field is not the originally identified site of 41ZV226, but rather a new site.

At roughly the same time that CAR was conducting the assessment of the FM 481 sites, archeologists with SWCA Environmental Consultants conducted an impact evaluation for TxDOT of FM 481 prior to road improvements scheduled to begin in 2003. That impact evaluation (O'Farrell and Miller 2002) focused only on the eight known sites in the Texas Archeological Sites Atlas. As a result of an oversight, SWCA was not informed of the previous work along the FM 481 right-of-way. SWCA recommended five of the eight known sites (41ZV197, 41ZV198, 41ZV201, 41ZV202, and 41ZV203) for further assessment. Subsequently, SWCA conducted additional work, including backhoe trenching and shovel testing, at these five sites (Miller et al. 2002). After this phase of the work, TXDOT and CAR provided SWCA with a draft of the assessment document (Greaves et al. n.d.) indicating that there were 14 sites originally documented by TxDOT along this stretch of FM 481 (see Figure 1-4.). SWCA archeologists subsequently returned to the area to conduct an additional evaluation of the remaining sections of FM 481. That work (Houk et al. 2003) identified one additional site (41ZV449), as well as redefined several of the previously identified field site numbers assigned by Greaves et al. (n.d.).

The resolution of the actual location of the hearth field and the original location of 41ZV226 identified by Henderson in 1981 creates a number of recording problems in that the location where Henderson placed 41ZV226 in 1981 now has two new trinomials, 41ZV452 and 41ZV453 (see Figure 1-4). In addition, the solution leaves the "hearth field" without a trinomial. However, as nothing was collected at the 1981 location of 41ZV226 by Henderson, we suggest that $41 \mathrm{ZV} 226$ be retained as the site number for the hearth field and that 41ZV452 and 41ZV453 be retained for the sites near the Gato Ranch crossing. This would essentially leave the site designations identified in Figure 1-4 intact.

Using the above reconstruction, CAR's assessment (Greaves et al. n.d.), and SWCA's recent work (Houk et al. 2003) to assign site numbers (see Figure 1-4), TxDOT conducted work on what we now consider to be nine sites along FM 481 during 1981 and 1982. Moving from east to west along the road, Henderson conducted testing at 41ZV197, 41ZV198, 41ZV451 (identified by Henderson as 41ZV201), 41ZV226, $41 Z V 453$ (identified by Henderson as 41ZV203A in 1982), and 41ZV202. Some level of map information exists for all these sites, along with collections and notes. Map information exists for 41ZV450, 41ZV452, and 41ZV201, though no testing was conducted at these locations.

\section{Project Activities}

Four goals guided the project. As noted previously, two major research domains involve lithic technology and paleoenvironmental reconstruction. The two additional goals were to provide a report on the field work and results of the 1981 and 1982 efforts, and to prepare the notes, photographs, and selected artifacts for permanent curation. Each of these is briefly discussed below.

Given the multiple burned rock hearths on the sites, CAR argued that individual features and feature-proximate artifact collections be considered the appropriate analytical units for any proposed analyses. Investigating lithic technology, and changes in that technology through time, involved establishing, with radiocarbon dates, the ages of features and associated lithic debitage and developing some measure of the likelihood that feature-proximate artifact assemblages 
are actually behaviorally associated with the use of the feature. To accomplish this, CAR identified several featureassociated radiocarbon samples from eight feature locations on three sites (41ZV198, 41ZV226, and 41ZV453). Our goal was to submit two samples from each feature area. We suggested that situations where the dates of the two samples from a given feature do not overlap at one-sigma are unlikely to have any integrity, and associated lithic samples are likely to represent mixtures from various time periods. In those cases were the dates do overlap, there is an increased probability that the features, and the associated lithic material, represent assemblages of higher integrity. Paired samples from five features produced overlapping dates, although in two of the five cases the dates were late (ca. A.D. 1520 to 1660 and A.D. 1520 to 1800 ) relative to the presumed prehistoric ages of the associated lithic materials. Comparison of the projectile points associated with these features further casts doubt on the behavioral association between the features and the lithic artifacts found in their vicinity. Therefore, we did not pursue this research theme further, since following these preliminary tasks we were left with little confidence in the association of feature-proximate lithics with the feature and its age.

The paleoenvironmental research domain specifically concerned xylem analysis of dated mesquite charcoal in an attempt to reconstruct prehistoric fluctuations in effective moisture regimes (Dering 2002; February 1992, 1994). We suggested that pairs of dated mesquite samples could be acquired from selected feature contexts, and that such data would further the paleoenvironmental potential of mesquite xylem analysis. To pursue this research, the charcoal samples discussed previously were submitted to Dr. Phil Dering for wood identification. Next, the identified mesquite samples were each split into two samples, one for radiocarbon dating and one for xylem analysis. Using these data, as well as other archeological samples, Dering was able to reconstruct oscillations in effective moisture regimes within the last 1,000 years represented by the mesquite charcoal samples studied. The results clearly establish the potential of the technique, and if confirmed by additional work in the region, provide important data for the reconstruction of one aspect of paleoclimate that could not easily be assessed for South Texas.

The third goal of the project was to provide a description of the field work activities and results of the 1981 and 1982 investigations. Based on the CAR assessment of the artifact collections and associated records, we concluded that there exists adequate documentation to report on what was done at most of the sites along FM 481. The archeological material primarily reflects an eroded deposit, dominated by small burned rock features. Much of the occupation seems to reflect the Late Archaic and Late Prehistoric temporal periods, with Late Archaic Ensor and Frio points and Late Prehistoric Sabinal types being the most common forms recovered. Radiocarbon dates from features generally support that temporal placement, with dates stretching back to before $1500 \mathrm{BP}$. Several more recent dates, however, are also present, suggesting the possibility of some Historic or Protohistoric use of the project area as well.

Finally, as part of the fourth deliverable, the documents produced by the excavations, including all notes and photographs, have been prepared for curation at the Center for Archaeological Research. Given the low temporal integrity of the assemblages, we have not curated all of the associated artifacts. Specifically, we have prepared all tools and cores for curation, along with debitage contained in a $10 \%$ random sample of each provenience. All other material has been discarded pursuant to Chapter $26.27(\mathrm{~g})(2)$ of the Texas Administrative Code and in consultation with the Texas Historical Commission and TxDOT.

\section{Overview of the Report}

This document contains six chapters and a single appendix. In Chapter 2 we present a short overview of the environmental setting of the project. In the third chapter we provide information on the cultural history of the region, including a selected summary of previous research in South Texas and in Zavala County. Chapter 4 describes each of the nine sites (41ZV197, 41ZV198, 41ZV201, 41ZV202, 41ZV226, 41ZV450, 41ZV451, 41ZV452, and 41ZV453) discussed in this report, though for many locations minimal information is available. In Chapter 5, we provide a summary of the original research design and discuss the research results that are primarily concerned with the xylem analysis. Finally, Chapter 6 provides a summary of the work. The radiocarbon results are presented in Appendix A. 



\title{
Chapter 2: Environmental Setting
}

\author{
Raymond P. Mauldin
}

The project area is part of the larger South Texas culturalnatural region that stretches south to the Rio Grande drainage and also includes the southeastern Sand Sheet, the central Mesquite-Chaparral and the Oak Forests and Savanna extending to the Guadalupe River drainage. However, with the exception of the review of paleoenvironmental conditions, we feel that our understanding of the sites is better served by focusing on the project area rather than the broader South Texas region. With this in mind, this chapter provides an overview of the environment of the project area and its immediate vicinity, historically known as the Brasada. Included are short discussions of the physiographic setting, climate, geology and soils, vegetation, and faunal resources. In the second section, paleoenvironmental conditions during the Late Holocene, the temporal period reflected in the archeological material, are considered. There is, however, minimal information on this topic for the South Texas region.

\section{Aspects of the Modern Environment}

The project area, visited by CAR personnel in 2002, is in northwest Zavala County, roughly $30 \mathrm{~km}$ to the southwest of the town of Uvalde and $50 \mathrm{~km}$ to the northeast of the town of Eagle Pass and the Rio Grande. The area is on the northern edge of the Tamaulipan biotic province (Blair 1950). In this portion of the province, the region is a sparsely vegetated plain characterized by a semi-arid climatic regime. Often referred to as the Costal Plain, Rio Grande Plain, or South Texas Plain, the region is characterized by low topographic relief and intermittent drainages, although several larger rivers, including the Nueces, Frio and Rio Grande, cut through the area. About $50 \mathrm{~km}$ to the north of the project area is the Edwards Plateau, an uplifted, limestone-dominated region characterized by relatively denser vegetation. Here, oak and juniper, often underlain by a variety of grasses, are common, and the setting is very different than that of the mesquite-acacia brushy flats of the project area.

\section{Climate}

Presently, the climate of the study area can be characterized as sub-tropical, with hot, humid summers and mild, dry winters (Natural Fibers Information Center 1987:533-534).
Figure 2-1 presents the average minimum and maximum monthly temperatures at Uvalde, Texas, between 1971 and 2000 (Southern Regional Climate Center [SRCC] 2003a, 2003b). During this period, July and August were the warmest months, with December and January being the coolest. The growing season in Uvalde County averages about 256 days per year. On average, 26 days a year are at or below freezing, and the maximum temperature exceeds $99^{\circ} \mathrm{F} 41$ times a year (Natural Fibers Information Center 1987:533-534).

The average annual precipitation between 1971 and 2000 at Uvalde was 23.43 inches. The data in Figure 2-2 show that the rainfall is, on average, bimodal during the year, with peaks in the early summer months of May and June and a smaller pear in late summer (August). The late winter to early spring months are the driest, with January, February and March all having rainfall of around one inch (SRCC 2003c). Year-to-year variability in rainfall is shown in Figure 2-3 with data from 1913 through 1982 (National Climate Data Center 2004). The wettest year during this period was 1976 with over 45 inches of precipitation, while the driest year was 1956 when less than 10 inches of precipitation was recorded.

\section{Geology and Soils}

Figure 2-4, adapted from the Del Rio (Barnes 1977) and San Antonio (Barnes 1983) sheets of the Geological Atlas of Texas, shows the geology of the general project area. At a regional level, Cretaceous-age limestone and marl deposits (Kac, Kau) dominate the northern area (Figure 2-4). Neither of these formations is noted to have chert present. The Anacacho Limestone (Kac) does contain isolated deposits of igneous rock (Ki), including basalt. Much of the project area itself is mapped as Pleistocene fluviatile terrace deposits (Qt) that are associated with the Edwards Plateau. These deposits often contain chert gravels. Holocene-age alluvium (Qal) floodplain deposits are associated with some of the major drainages (Figure 2-4). The Escondido Formation (Kes), also present in the project area, contains shale, siltstone, sandstone and colluvium. The Eocene-age Indio Formation (Ei) also contains sandstone, shale, and siltstone. Chert is not common in the study area, though a variety of materials well suited for hearth stones (sandstone and limestone) may be available. 


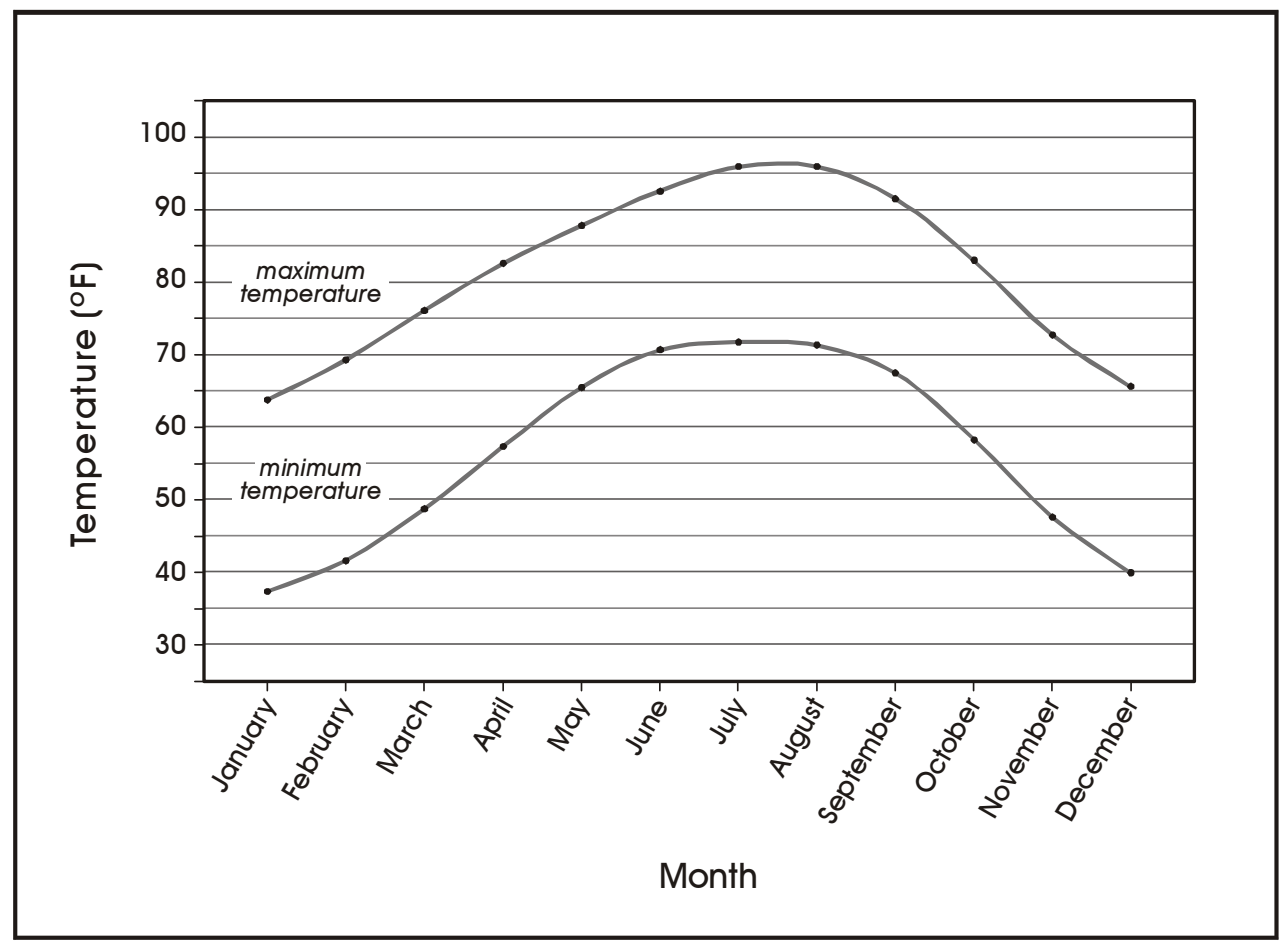

Figure 2-1. Average monthly temperature at Uvalde, Texas, 1971-2000.

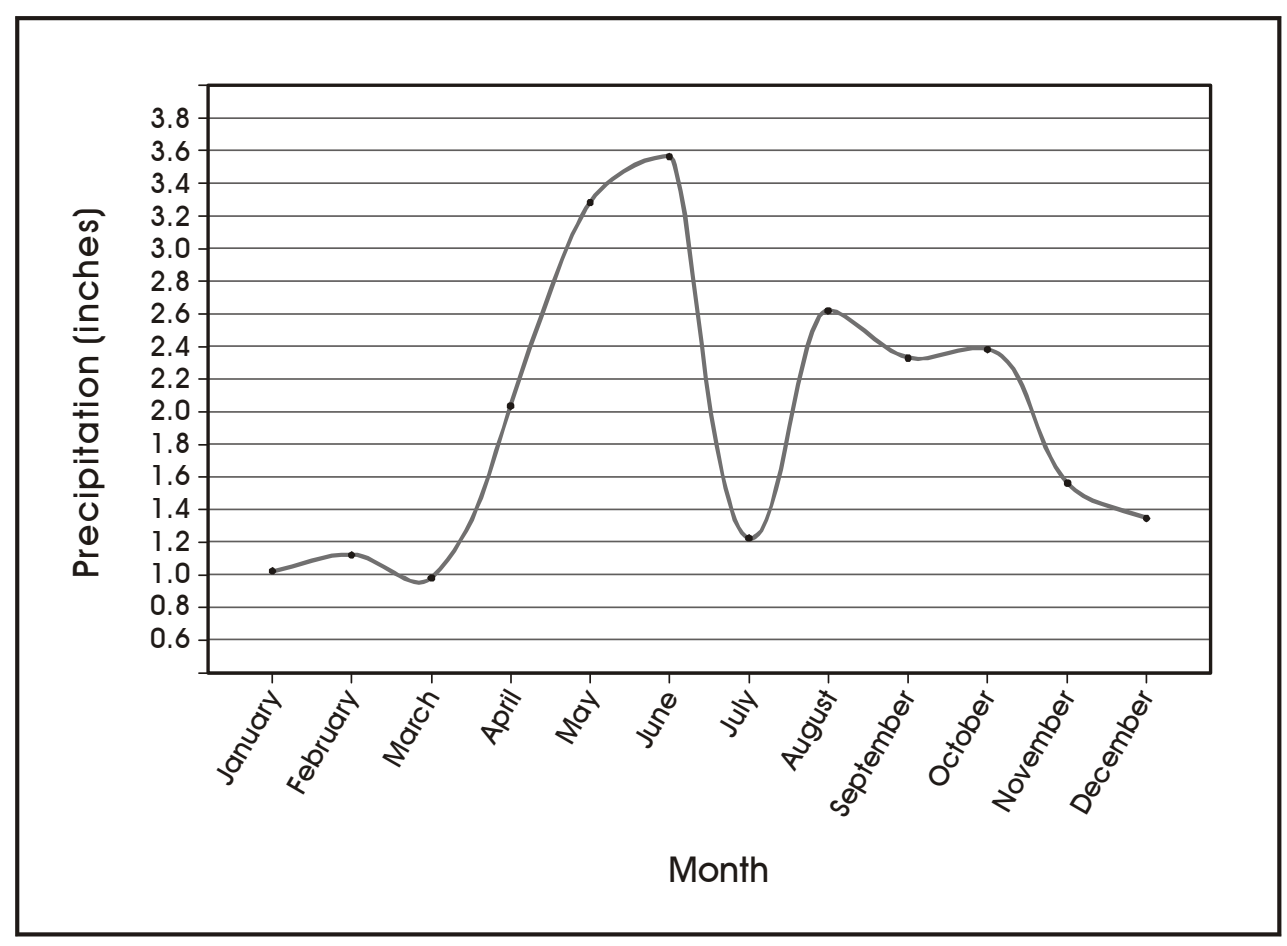

Figure 2-2. Average monthly precipitation at Uvalde, Texas, 1971-2000. 


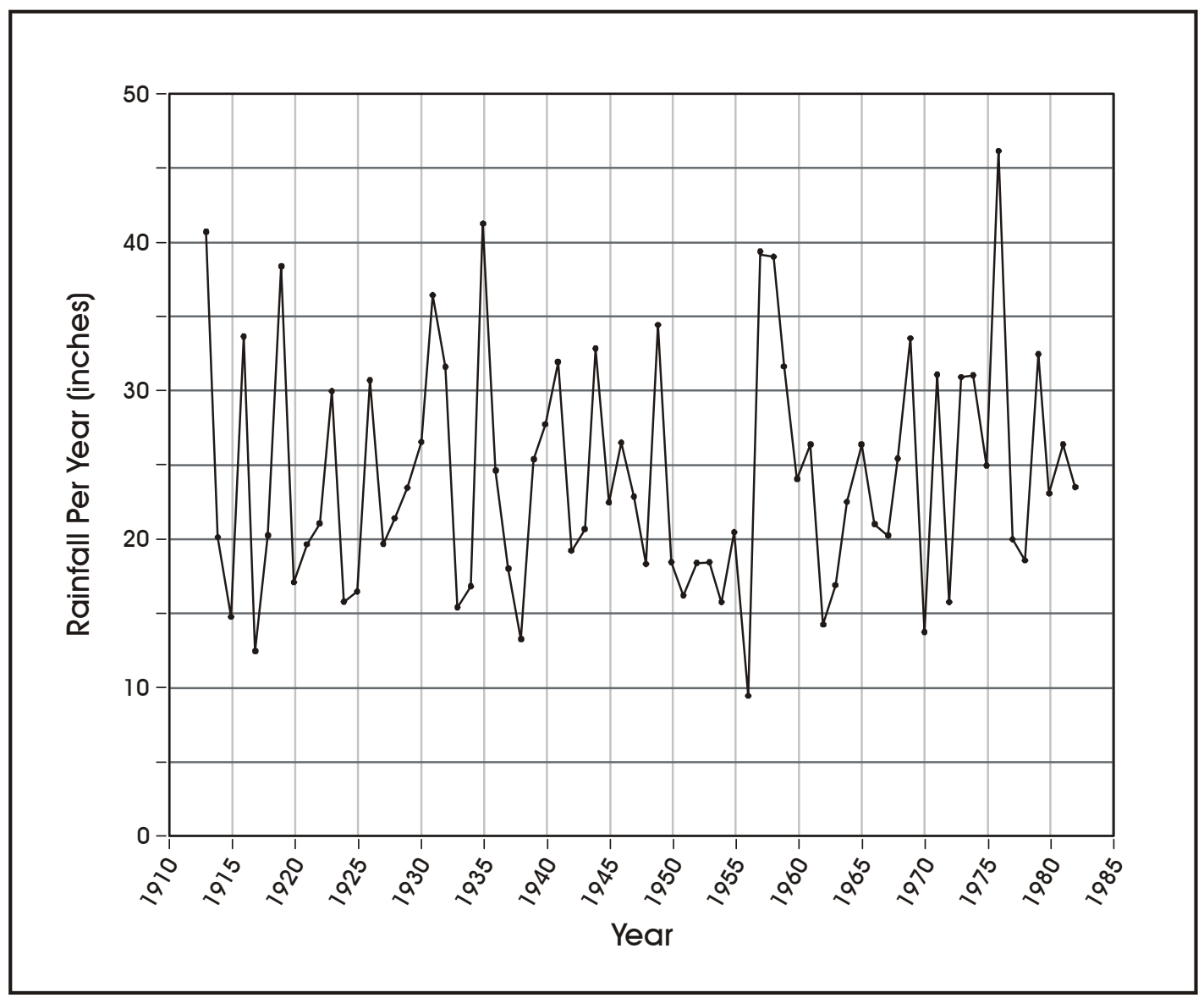

Figure 2-3. Yearly rainfall at Uvalde, Texas.

Figure 2-5 presents the soils of the project area (Stevens and Arriaga 1985). Much of the project area is dominated by Uvalde silty clay loam (UVB), with Pryor sandy clay loam (PYB), Chacon clay loam (CKB), and Caid sandy clay loam (CDB) also common. All of these soils are deep and well drained, with the Chacon, Uvalde, and Caid series being frequently associated with the drainages present in the region. Tonio fine sandy loam (TOB) and Zavco sandy clay loam (ZVB) are also mapped within the project area.

It is also worth noting that three relatively unusual geological features in South Texas are located within 20 miles of the project area. The first of these is a large deposit of natural asphaltum in the Anacacho Limestone Formation (Kau) 56 miles northwest of the project area. Al McGraw (personal communication 2004), TxDOT archeologist, indicates that this deposit was once the source of most pavement asphalt in the state. McGraw also indicates that some researchers (H. E. Bolton and T. N. Campbell) believed the Anacacho Mountains were the location of the historical Sierra de Yacatsol, a Nahuatl term signifying "stone nose." The second unique geologic feature consists of the numerous basaltic dome outcrops that are found throughout the southern half of Uvalde County. It is likely that these outcrops served as important sources of raw materials for prehistoric groups, as reflected by archeological materials recovered from 41ZV35 and 41UV42 (McGraw, personal communication 2004). Finally, the massive concentration of astrobleme breccia (Ec; Geologic Atlas of Texas San Antonio Sheet, revised 1982) in the Carrizo Sand Formation near the Nueces River and north of La Pryor may be associated with a former meteorite impact (McGraw, personal communication 2004). 


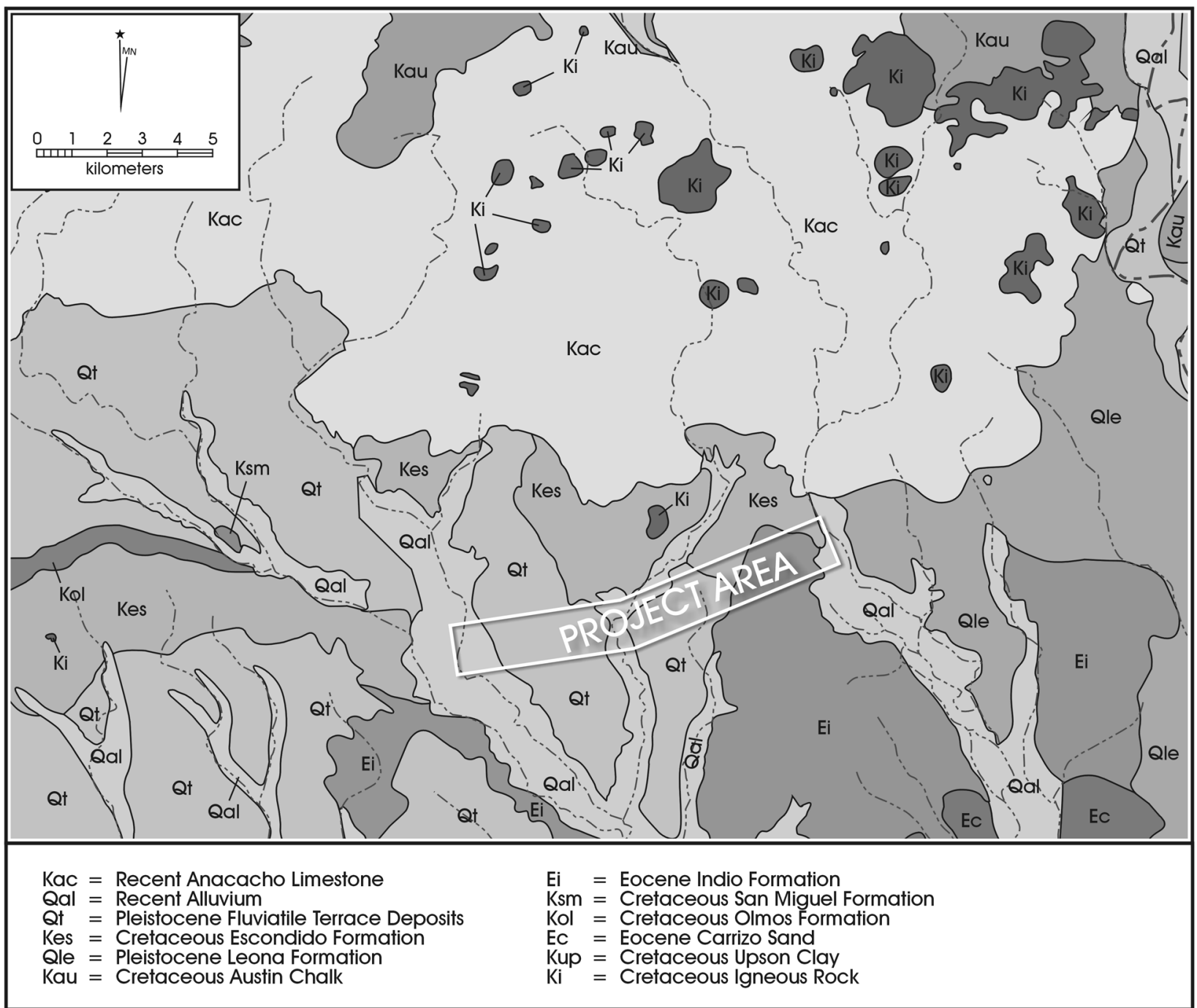

Figure 2-4. Geology in the project area. Adapted from Barnes 1977 and 1983.

\section{Hydrology}

As noted previously, several large, permanently flowing rivers cut through the South Texas region, and a variety of smaller creeks and drainages are clearly present (see Figure 1-2). The major rivers include the Rio Grande, Nueces, Frio, Sabinal, and San Antonio systems. Many of these drain out of the Balcones Escarpment, and several are principally spring fed. Within the project area, Turkey Creek, a semipermanent drainage, flows near the eastern edge of the study area and is currently the primary source of surface water in the area. A number of smaller drainages, including Gato Creek, Olmos Creek, and Muela Creek, cut through the region. All of these smaller drainages were dry in 2002, and flows are probably only present under conditions of heavy localized rainfall. This current picture of water availability, however, is certainly not reflective of past conditions. Deep twentieth-century water wells in the region appear to have dramatically lowered the water table, probably resulting in less surface flow (see Hester 1980).

In addition to flowing water, playa lakes such as Green Lake and Mato Oso Lake in Zavala County may also have provided a seasonal source of water and localized microhabitats for flora and fauna. The convergence of these resources would also have provided preferred seasonally predictable camping locations for human groups utilizing and traversing through this region. 


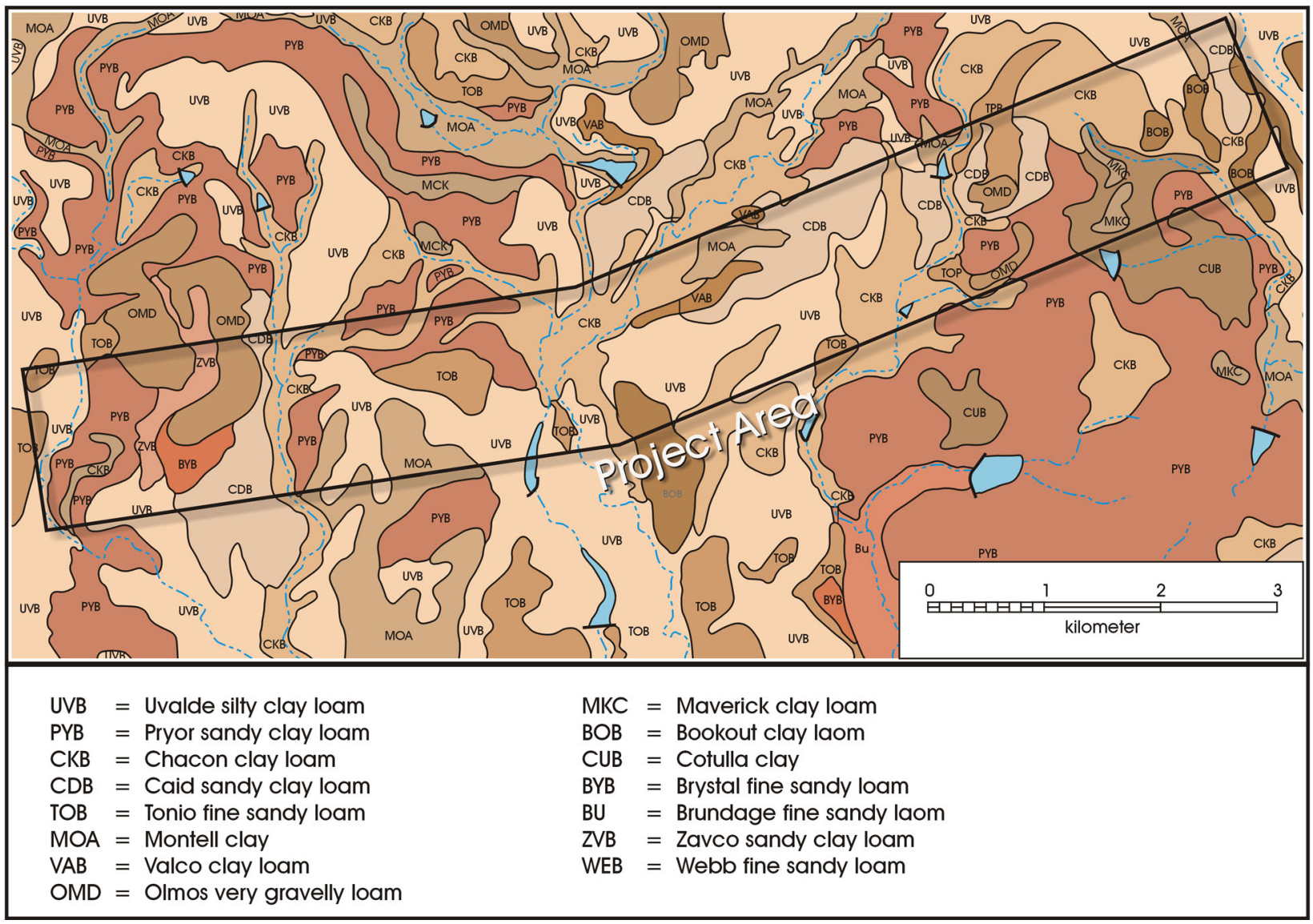

Figure 2-5. Soils in the project area. Adapted from Stevens and Arriaga 1985.

\section{Floral and Faunal Resources}

The modern vegetation in the project area is depicted in Figure 2-6 (Texas Parks and Wildlife Department [TPWD] 1999). Currently, mesquite (Prosopis glandulosa) and blackbrush (Acacia rigidula) dominate much of the landscape, with small pockets of native and introduced grasses present (Figure 2-6). Riparian zones are dominated by sycamore (Platanus occidentalis), black willow (Salix nigra), and button brush (Cephalantus occidentalis), along with catclaw (Acacia sp.), whitebrush (Aloysis gratissima), and mesquite (TPWD 1999). Live oak (Quercus virginiana) and ashe juniper (Juniperus ashei) parks and woods are present to the north of the project area on the escarpment (TPWD 1999). Like the hydrology of the area, the current vegetation structure has clearly been impacted by Spanish Colonial practices and later European settlement and land use. The introduction of domestic livestock, fencing, and fire suppression, combined with overgrazing and deep well irrigation, seems to have contributed both to a lowering of the water table and the spread of brushy vegetation, especially mesquite (see Hall 1985; Hester 1995). Some early Spanish accounts describe the region of present-day Zavala County as being mainly prairie, with dense forests in the riparian areas and infrequent thickets of mesquite (see Robbins 1998). There are also mentions in some accounts that the thorn brush vegetation was well established in some areas (Espinosa's diary of the 1716 Ramón expedition; Foik 1933; Tous 1930). In addition, the recovery of mesquite wood charcoal from hearths dating to $3000 \mathrm{BP}$ from Choke Canyon sites does indicate that some species forming the Brush Country vegetation community were present prior to historic times.

The project area is on the edge of the Tamaulipan biotic province. Blair (1950) lists over 60 mammalian species for 


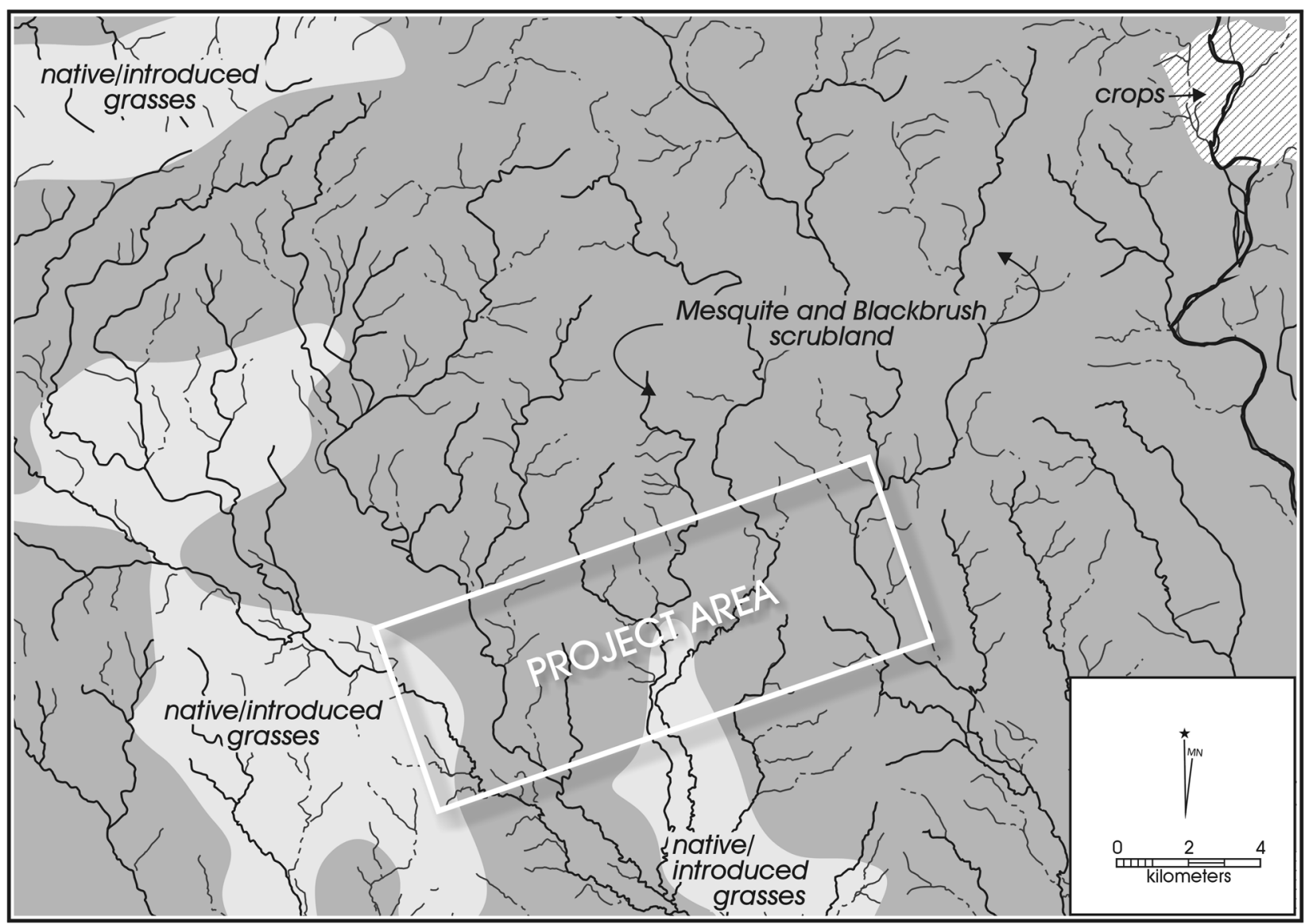

Figure 2-6. Modern vegetation in the project area.

the Tamaulipan province. These include white-tailed deer (Odocoileus virginianus), the major herbivore in the region today, and a variety of smaller mammals, including cottontail rabbit (Sylvilagus sp.), jackrabbit (Lepus californicus), coyote (Canis latrans), and small rodents. Blair (1950) also lists 36 species of snakes and 19 species of lizards for this province. Historically and prehistorically, a variety of additional species, including several economically important animals such as bison and antelope, were also present (see Davis and Schmidly 1994; Montgomery 1978).

\section{Paleoenvironmental Conditions}

Much of the prehistoric occupation of the current study area seems to have been during the Late Archaic and Late Prehistoric periods. This time frame, roughly corresponding to the last 4,000 years, is the focus of this section. At a general level, little information exists specifically for the South Texas region. In part, this is due to poor preservation conditions.
In addition, the region generally lacks environmental features such as peat bogs, lake deposits, and dry, deep caves that are conducive to preserving environmental data. Much of what we currently know about paleoenvironmental conditions in the Late Holocene comes primarily from Central Texas and relies on a variety of different data sets, including the presence/absence of bison, reconsideration of pollen data collected in the 1940s, and fluctuations in shrew species in poorly dated cave deposits (see Bousman 1998; Collins 1995; Dillehay 1974; Johnson and Goode 1994; Nordt et al. 1994). The application of the scenarios created from these diverse data to the South Texas region is unclear. This ambiguity is related both to the distance between these study regions and the fact that there is little consensus between several of the scenarios for the Late Holocene.

There are, however, several studies that are close to the current project area that contain some data of interest. Foremost among these is the work of Robinson (1982) at 
Choke Canyon. Though located roughly $180 \mathrm{~km}$ to the southeast of the project area, the study does fall within the South Texas region. Relying on changes in phytoliths reflected in several archeological sites, Robinson (1982) was able to establish baseline data for the period from about $5300 \mathrm{BP}$ to $1000 \mathrm{BP}$. Much of this period can be characterized as xeric, with two pronounced mesic intervals. The first of these seems to have occurred early in the sequence, between about 5300 $\mathrm{BP}$ and $4300 \mathrm{BP}$, while the second occurred between 3200 BP and 2500 BP (Robinson 1982; see also Robinson 1979).

Nordt (1998), working in Maverick County just to the southwest of the current study area, used stable carbon isotopes from alluvial deposits associated with both Elm Creek and the Rio Grande to monitor major shifts in vegetation communities. Focusing on the end of his roughly 8,000-year sequence, the data seem to suggest that $\mathrm{C} 4$ plants increased around $4000 \mathrm{BP}$, and generally decreased after that date with two possible exceptions. The first of these is between $2200 \mathrm{BP}$ and $1200 \mathrm{BP}$, and a second increase in C4 vegetation probably occurred sometime after $1000 \mathrm{BP}$ (Nordt 1998). Nordt (1998) further suggests that high C4 vegetation is probably related to warmer temperatures, while an increase in C3 vegetation is related to cooler temperatures (see also Bryant and Holloway 1985).

More recently, Dering $(2000,2002)$ has used an analysis of mesquite vessel diameters and densities to investigate rainfall shifts in southern Texas. His analysis of charcoal from the Lino Site in Webb County, roughly $200 \mathrm{~km}$ to the south of the current project area, suggested that a xeric period was present around $3200 \mathrm{BP}$, with a period of increasing moisture present around $2000 \mathrm{BP}$, though the exact timing of these events is not clear (Dering 2000). Dering continues this work on the current project and concludes that modern precipitation conditions began to be established roughly 200-300 years ago in South Texas. Between 400 and 650 years ago, greater precipitation seems to have been present, with very dry conditions prevailing between 800 and 1,100 years ago.

The overall climate pattern suggested by these various studies is unclear. For example, both Dering (2000) and Robinson (1982) suggest more favorable moisture conditions sometime around $2000 \mathrm{BP}$ or $2500 \mathrm{BP}$, but Nordt (1998) suggests that sometime after 2200 BP warmer temperatures are present, as indicated by higher $\mathrm{C} 4$ vegetation signatures. The use of different data sets that are probably responding to different scales of climate, temporal uncertainty in some of those data sets, and a small number of temporal points, all contribute to the lack of clarity regarding Late Holocene climate and vegetation conditions. Understanding Late Holocene climate in the South Texas region remains a major research priority. 



\title{
Chapter 3: Archeological Setting
}

\author{
Raymond P. Mauldin and Bruce K. Moses
}

In this chapter, we provide background material on the archeological record of the general study area. Included is a short review of the history of research in the immediate project area and a summary of the cultural history. While we provide a brief summary of cultural historic trends during the Paleoindian, Early and Middle Archaic periods, as with the paleoenvironmental discussion in the previous chapter, much of this review focuses on the last 4,000 years, the known time frame of the archeological material from the project.

Several recent summaries of archeological research in southern Texas are available, including overviews by Black (1989) and Hester (1995). It appears that little work was done in the area prior to the late 1960s and early 1970s. The Hartle and Stephenson (1951) report on work performed at Falcon Reservoir probably represents one of the earliest professional publications in the region. Several major projects have been undertaken in the region since that time, including a series of surveys and site testing projects at Choke Canyon in Live Oak and McMullen counties (Brown et al. 1982; Hall et al. 1982). Several other large-scale survey projects, such as the East Chacon project (McGraw and Knepper 1983) in Zavala and Uvalde counties, the Chaparrosa Ranch project in Zavala County (Hester 1978), and the proposed Applewhite Reservoir project in southern Bexar County (McGraw and Hindes 1987) also have been completed. In addition, several testing and excavation projects have been completed in South Texas (e.g., Black 1986; Brown et al. 1982; Hall et al 1986; Miller et al. 2000; Quigg et al. 2002; Scott and Fox 1982; Taylor and Highley 1995; Vierra 1998), including several near the current project area. Specifically, Hester and Montgomery conducted testing at the Late Prehistoric and Late Archaic Mariposa site (41ZV83) in 1974 and 1975 (Montgomery 1978) and TxDOT conducted work at the multicomponent Anthon site in southern Uvalde County in 1975 (Goode 2002).

As demonstrated by the above references, while some portions of South Texas have seen a variety of recent excavation projects (e.g., Mahoney et al. 2002; Quigg 2000; Quigg et al. 2000), surprisingly little data recovery work has been conducted in southern Uvalde or Zavala counties since the early 1980s (Lukowski 1987). In spite of the age of the work reported here, results from the sites discussed in this report can add important descriptive data for this under-studied and under-reported area of southern Texas.

\section{Archeological Framework}

As noted previously, South Texas has had a relatively low level of professional archeological work. Sites are frequently eroded, and deeply stratified rockshelter deposits have not been excavated. As a result, the chronology of the region is poorly developed. Chronologies developed for Central Texas are commonly applied to the region, although it is still unclear if that application is appropriate. Much of what seems to be known about the chronological sequence is from surface distributions of artifacts. Hall et al. (1986), Black (1989), and Hester (1995) have all reviewed the regional chronology. However, because the sites reported on in this document seem to date primarily to the Late Archaic, Late Prehistoric, and perhaps the early Historic periods, we will provide only a brief overview of what is known concerning the Paleoindian, Early Archaic, and Middle Archaic occupations of the region.

\section{Paleoindian, Early and Middle Archaic}

According to Hester (1995), a variety of Paleoindian-age artifacts tend to be recovered in small numbers throughout the region, including isolated projectile points (i.e., Largent et al. 1991; Meltzer and Bever 1995; Tomka 1999) and polyhedral cores (Chandler 1992; Collins and Headrick 1992; Houk et al. 1997; Kelly 1992). Cores tend to be found in the northern portion of the region in the vicinity of quality chert resources derived from Edwards Formation limestones. The recently published report on the Pavo Real site, 41BX52, is an example of the Paleoindian raw material procurement activities that may have regularly taken place in proximity to the southern edge of the Edwards Plateau (Collins et al. 2003). Projectile points are more widely distributed and are often found in complete or heavily rejuvenated forms suggestive of hunting losses or intentional discard. While these finds and their low density suggests low-intensity use of the region, with the exception of technological information, few other things can be learned from them about Paleoindian adaptations.

Early Archaic materials dating from roughly 9000-3000/ $2500 \mathrm{BP}$ are represented by a variety of projectile point types (i.e., Early Corner Notched Horizon specimens, Early Basal Notched Horizon specimens; Hester 1995) and tool forms (i.e., Clear Fork tools, Guadalupe tools; Hall et al. 1982). 
Nonetheless, technological connections to Paleoindian forms still remain as seen in the widely distributed Angostura points that are commonly viewed as Archaic in affinity (Collins 1995; Johnson and Goode 1994).

The relatively short Middle Archaic period (2500-400 B.C.) represents a dramatic shift in projectile point and tool assemblages in South Texas. Stemmed projectile point forms associated with Central Texas and Lower Pecos traditions are still present at the northern (i.e., southern edge of the Edwards Escarpment) and western (i.e., Lower Pecos) edges of the region. However, throughout much of the remainder of South Texas, unstemmed projectile point forms (i.e., Abasolo, Refugio, Tortugas [Miller et al. 2000], Matamoros, and Catan) and distally beveled tools (i.e., Dimmit unifaces [Nunley and Hester 1966], Nueces tools [Hester et al. 1969], Olmos bifaces [Hester 1969]) become the prevalent artifacts with the general assemblages tending to continue throughout the Late Archaic period. The forms bespeak of cultural relationships with regions south of the border with Mexico and probably reflect broad hunter-gatherer adaptations that formerly characterized both South Texas and northern Tamaulipas (Mahoney et al. 2002). These commonalities are present not only within the technological aspects of culture but also are reflected within burial traditions that seem to be quite distinct in South Texas from other northern or coastal plains traditions (Perttula 2001; Taylor and Highley 1995).

\section{Late Archaic Chronology and Occupation Patterns}

For the South Texas area, Hester (1995:441) suggests that the Late Archaic dates from roughly 400 B.C. to about A.D. 600-700, although few radiocarbon dates seem to be available. Projectile point types found in sites from this period include Ensor, Ellis, Frio, Fairland, Montell, and Marcos, typical of Central Texas chronologies, as well as Shumla, Catan, Zavala, Matamoros, and Tortugas forms (see Brown et al. 1982; Creel et al. 1979; Goode 2002; Hester 1978; Quigg et al. 2000). Late Archaic assemblages from some areas of South Texas frequently have Olmos tools, small triangular bifaces possibly used as gouges (Shafer and Hester 1971). Manos and metates are frequently found at sites from this time period, and many locations seem to have fire-cracked rock hearths in abundance (e.g., Goode 2002).

Our knowledge of subsistence and settlement during this period in South Texas is minimal, in part, as a function of the eroded nature and poor preservation of sites from this time period. However, excavations at Choke Canyon did recover fauna from a variety of small animals including rabbits and rodents, and the remains of mussels, fish and turtles. Deer were also recovered (Brown et al. 1982; Hall et al. 1986). Hester (1995) suggests that the high frequency of snails in many Late Archaic sites in the Choke Canyon area reflects their use as food.

Late Archaic settlements appear to have been concentrated along streams and drainages, with high terraces and ridges providing sources for tool stone.

\section{Late Prehistoric Chronology and Occupation Patterns}

The chronological patterns of the Late Prehistoric period in South Texas appear to be somewhat better known than the Late Archaic, though gaps are still present, especially in the early part of the period. Dating from roughly A.D. 700 to as late as A.D. 1600 or A.D. 1650 , this period is characterized by point types typical of Central Texas, including Scallorn, Edwards, Sabinal and Perdiz forms (Black 1986; Goode 2002), with Caracara, Star, Zavala, and a variety of other more regional arrow point types also present (Kumpe et al. 2000; Turner and Hester 1999). In several contexts, small, Late Archaic forms such as Ensor, Catan, and Matamoros points occur in Late Prehistoric assemblages, and Zavala points appear to be present in Late Archaic assemblages as well (see Hester 1995; Turner and Hester 1999). It is unclear, though, if these associations are in good context. Bonetempered pottery is also present during this period, along with end scrapers, beveled knives, perforators, and ground stone.

Austin Interval projectile point forms such as Scallorn are present and common in some archeological sites in South Texas (c.f. 41ZV202, recently tested by the Center for Archaeological Research), although the nature of this early Late Prehistoric sub-period adaptation in South Texas is poorly understood. For instance, Feature 4, an organically enriched 40-cm-thick stain rich in lithic debitage and Scallorn projectile points found at 41ZV202 dates from A.D. 960-1030. The feature is suggestive of some type of repeatedly used surface but it is unclear at this time whether it represents a structure floor, a discard area, or some other activity surface. Faunal remains are infrequent within the excavated portion of the site and several small burned rock clusters are suggestive of repeated food preparation activities. 
While 41ZV202 and other Austin Interval sites provide us with little information on prehistoric subsistence, faunal material from Toyah Interval South Texas sites include a variety of taxa (e.g., Black 1986). Hester (1995; see also Black 1986; Hall et al. 1986) notes that 45 different taxa, including bison, deer, antelope, and a variety of smaller animals, have been recorded for Toyah Interval Late Prehistoric sites in the region. Settlement seems to be similar to the preceding Late Archaic period, with sites frequently located along streams and drainages.

\section{The Protohistoric/Historic Period}

Following Hester (1995:449-450), we identify the Protohistoric as a period when Native American groups may have been contacted by Euro-American explorers but these contacts were infrequent or involved such small numbers of individuals that they left no lasting effect on the indigenous cultures. In this context, the period from the 1530s through the late 1600 s may be considered as encompassing the Protohistoric. By the very late seventeenth century (1689) native populations began to be regularly exposed to large groups through repeated entradas into Texas who left more direct and lasting impacts on native cultures. The Protohistoric period (1534-1689) is briefly mentioned here since several radiocarbon dates from the current project appear to fall within this time frame. The period begins around A.D. 1534 when Cabeza de Vaca entered this region (Campbell and Campbell 1981; Hester 1995). The Spanish influence in the region was further solidified with the establishment of settlements and missions in the early 1700s during the Historic period. Guerrero points are commonly recovered from mission contexts (see Hard et al. 1995) and they are generally dated to between A.D. 1600 and 1800 (Turner and Hester 1999). Metal is also introduced during this period, along with a variety of mission-era ceramic types.

Several sites with potential Protohistoric assemblages or radiocarbon dates have been investigated, including 41MC296 at Choke Canyon (Hall et al. 1986) where metal and a Guerrero point were recovered in association with Protohistoric radiocarbon dates. The presence of metal artifacts may also be indicative of the Historic period, although small numbers of Euro-American goods may have fallen into the hands of native groups prior to the regular occurrence of entradas into the region. In Zavala County, Inman et al. (1998) report on 41ZV155, a site excavated in the early 1970s. An assemblage containing Scallorn and Perdiz points, a single Cuney point, and 82 bone-tempered ceramic sherds was associated with two radiocarbon dates that appear to be Protohistoric in age. In addition, two radiocarbon dates from the Mariposa site (41ZV83) produced Protohistoric dates associated with what appear to be Late Prehistoric and some Late Archaic materials (Hester 1978; Montgomery 1978). However, neither site produced metal or ceramics that would be associated with the Historic period, and the association of the prehistoric assemblages with the radiocarbon dates is unclear.

Given the problems with artifact and radiocarbon date associations, and a clear definition of Protohistoric sites, we know little about settlement patterns or subsistence during this period. While several lists of faunal assemblages are presented for sites with Protohistoric dates (e.g., 41ZV83 and $41 Z \mathrm{~V} 155$ ), these assemblages are dominated by Prehistoric artifacts. It is clear that throughout this time period bison were present in some areas of South Texas, and antelope and deer were also available. It would be surprising if these animals were not a component of Protohistoric subsistence.

Numerous translations of original expedition logs exist describing the landscape, resources, and native groups encountered throughout the northern fringes of South Texas. In addition, several summaries and descriptions are also available, pulling together different aspects of these descriptions (i.e., McGraw et al. 1998; Foster 1995; Wade 2003) and describing aspects of Native American life in both Texas and on the northern frontiers of Mexico (Griffen 1969, 1979; Hackett 1971[1931]). The original records and these sources can provide valuable information regarding the practices and interactions between indigenous groups during the early Historic period.

\section{The Archeological Record of the Study Area}

As a final component of our investigation into the archeological remains associated with the current project, we conducted a review of the Texas Archeological Sites Atlas database in early 2004. The review focused on Zavala County. The 2004 review found 407 archeological sites listed. Of these 407, 221 lacked information on temporal placement. Of the remaining 186 sites, seven are recorded as Paleoindian, 90 are recorded as Archaic (with no information on subdivisions) and 24 are recorded as Late Prehistoric. The remaining 65 have material that appears to 
date to more than one broad temporal period. There are eight sites with Paleoindian, Archaic, and Late Prehistoric materials, eight sites with Paleoindian and Archaic remains, and 49 sites with Archaic and Late Prehistoric remains. Over $54 \%$ of the 407 sites lack any temporal information, and of those sites with diagnostics $(\mathrm{n}=186), 35 \%(\mathrm{n}=65)$ are clearly multicomponent, and the majority of the 90 "Archaic" sites probably contain point types that cross-cut large periods of time. This high frequency of multicomponent sites is probably a result both of the erosion of deposits characteristic of the region as well as the probability that occupation was centered along the geographically limited riparian settings.
Many of the sites listed on the Texas Sites Atlas are associated with two projects conducted near the current project area - the Chaparrosa Ranch and the East Chacon projects, located to the south and east of FM 481 (Figure 3-1). The Chaparrosa Ranch project was a long-term investigation involving survey, testing, and larger-scale excavation (see Hester 1978). Several sites, including sites 41ZV83 (Montgomery 1978) and 41ZV10 (Hester 1978), have had some level of excavation, along with radiocarbon dates. Unfortunately, much of this material remains unpublished or under-published. The East Chacon project is also under-reported, although McGraw and Knepper (1983) do provide descriptive data on 66 surveyed sites, along with

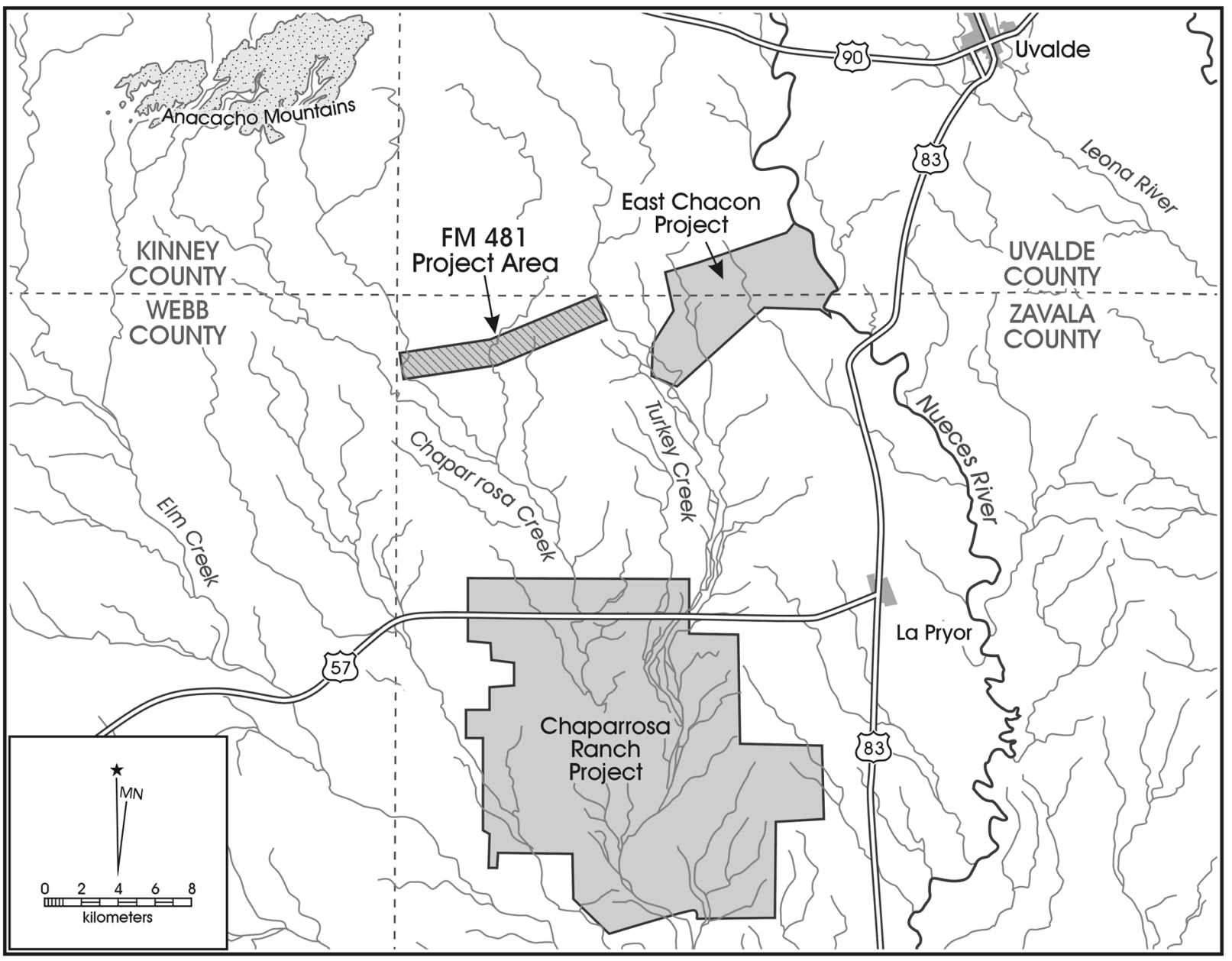

Figure 3-1. Location of the Chaparrosa Ranch and East Chacon archeological projects. 
some testing information on one site. The utility of these site descriptions is, however, hampered by a lack of temporal placement, although the project does provide some data on site location that is consistent with the expectation that most sites appear to be concentrated along drainages.

\section{Summary}

As this brief review suggests, we have a limited understanding of many aspects of the archeological record of South Texas in general and the project area in particular. In part, this is related to a lack of recent work, at least in the current study area, and the eroded and potentially multicomponent nature of many of the sites. We currently have a limited understanding of chronological patterns in diagnostic point types, with what are presumed to be Late Archaic and Late Prehistoric types often appearing in the same context, and those contexts having Protohistoric age radiocarbon dates. While it is likely that many of these situations simply represent cases with limited integrity, the resulting chronological confusion further limits our understanding of both subsistence and settlement patterns. 



\title{
Chapter 4: Archeological Methods and Site Descriptions
}

\author{
Bruce K. Moses, Russell D. Greaves, Raymond P. Mauldin, and Jason D. Weston
}

This chapter provides site descriptions for nine archeological sites along the FM 481 project area (see Figure 1-4). These include five sites (41ZV197, 41ZV198, 41ZV201, $41 \mathrm{ZV} 202$, and 41ZV226) originally recorded and tested by TxDOT archeologists in 1981 and 1982, and revisited by SWCA in 2002, and four newly recorded sites (41ZV450, 41ZV451, 41ZV452, and 41ZV453) investigated by SWCA in 2002 (O'Farrell and Miller 2002; and Houk et al. 2003). The descriptions are based primarily on notes recorded by Jerry Henderson in 1981 and 1982. Those descriptions are supplemented by data on transit maps of eight segments of FM 481 where burned rock and hearth features were seen in the graded roadway. Additional details about the recording procedures, records, collections, and site locations can be found in Greaves et al. (n.d.).

The archeological work described here was conducted under less than ideal conditions. Greaves et al. (n.d.) note that in 2002, project archeologist Jerry Henderson recalled that her crew was working on a project near Uvalde when they were rapidly shifted to Zavala County to perform salvage investigations. The project was conducted in response to informal notification that road improvements were being performed prior to examination of known archeological resources. This salvage effort resulted both in hasty excavation and low levels of recording. In general, grid designations of test units, for the sites that used a grid coordinate system (41ZV197, 41ZV198, 41ZV453, and $41 Z V 226)$, specify the southeastern corner of each test excavation. Grids were referenced to a central N0/W0 point. Most test units were 2-x-2-m squares, and provenience was most commonly recorded at that level rather than at 1-x-1-m units. All test units were excavated in 10-cm levels, with the exception of what turned out to be modern coyote burials encountered on 41ZV202. Actual terminal elevations were shot with a transit on several test units. This provides some information about the excavation errors in relation to target depths. This sample of recorded final level elevations indicates that excavations frequently exceeded target level depths by $1-40 \mathrm{~cm}$ in some portions of test units. All sediments, except those identified as recently disturbed overburdens from roadwork, were screened using $1 / 4$-inch mesh (Greaves et al. n.d.).

Sites are discussed in a sequence moving from east to west along FM 481 (see Figure 1-4). No work, other than counting, has been conducted on the debitage. Faunal remains were examined, identified, counted and weighed at the CAR laboratory. The data on animal bone provided in the site descriptions comes from this recent analysis of faunal remains. Burned rock is the only class of cultural artifacts that was not quantified or collected during excavations, although some burned rock is present in the collections.

\section{$41 Z V 197$}

Site 41ZV197 is located in an upland environment on the east bank of Turkey Creek (see Figure 1-4). It sits on a high terrace, adjacent to an unnamed third order tributary of Turkey Creek, at an elevation of roughly $810 \mathrm{ft}$ (247 m) AMSL. The site is on deep and loamy Uvalde silty clay loam soil that follows the contour of the bank overlooking the creek. This soil would have been of ideal composition to support native grasses intermixed with occasional stands of mesquite trees or woody shrubs (Stevens and Arriaga 1985). FM 481 bisects the identified site. The area of 41ZV197 within the right-of-way is estimated to be $10,065 \mathrm{~m}^{2}$ (2.49 acres).

TxDOT archeologist Daymond Crawford originally recorded site 41ZV197 in 1981 as a prehistoric scatter of fire-cracked rock and chert debitage. Also noted, though not described in any detail, was historic debris associated with the remains of a nineteenth-century stagecoach stop. TxDOT archeologist Jerry Henderson conducted testing at the site in July and August of 1982. A recent revisit to this site was performed by SWCA in June 2002 (O'Farrell and Miller 2002). That investigation included examination of the site surface and backhoe trenching. Their evaluation of $41 \mathrm{ZV} 197$ was that most of the surface accumulations of burned rock were the result of mechanical disturbance and represented push piles. The area within the current right-ofway was determined to have no additional research potential. No subsurface remains were identified.

\section{Fieldwork}

TxDOT's 1981/1982 testing of 41ZV197 was limited. Five 2-x-2-m test units were excavated within the right-of-way (Figure 4-1), and some surface material was collected. Overall, $1121-\mathrm{m}^{2}$ levels, each roughly $10 \mathrm{~cm}$ in thickness, were removed. While approximate, this suggests that $11.2 \mathrm{~m}^{3}$ of 


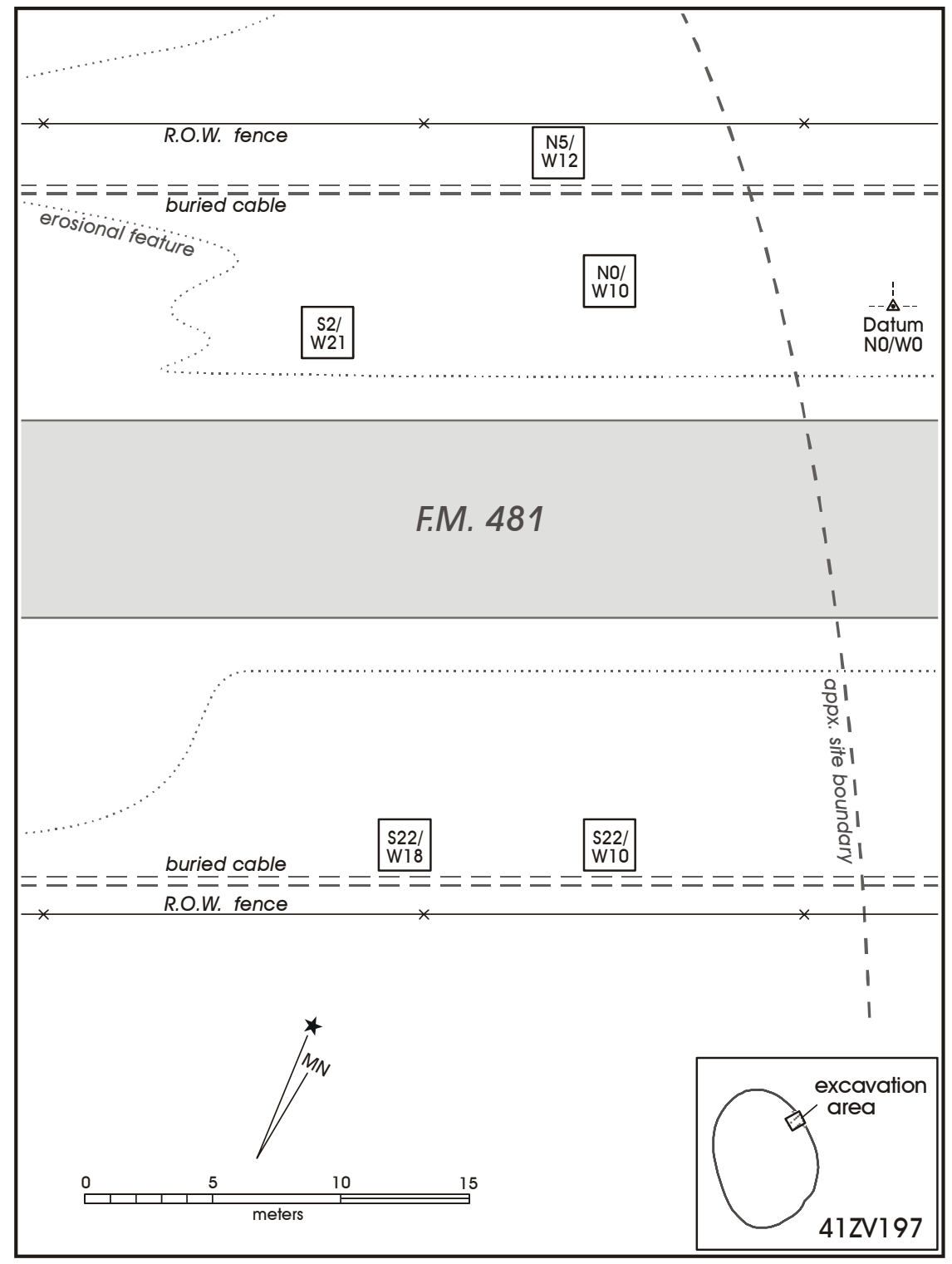

Figure 4-1. Excavation units at 41ZV197.

sediment was screened during testing. Roughly $8 \mathrm{~m}^{3}$ were screened from 0 to $40 \mathrm{~cm}$ below surface (bs), and no excavation occurred below $70 \mathrm{~cm}$. One feature, 1,906 pieces of debitage, one core, 22 chipped stone tools, and six points were recovered from the excavation (Tables 4-1 and 4-2). In addition, five bone fragments, 456 snail shells, and mussel shells from 15 different proveniences were recovered. Historic artifacts $(\mathrm{n}=70)$ were also collected, including 35 pieces of glass, 26 pieces of metal, and nine historic ceramics.
Feature 1 consists of a small distribution of fire-cracked rock (FCR) discovered in Level 1 of S22/W10 (Figure 4-2). A small amount of fire-cracked rock was removed from the edge of the feature before it was identified as a feature (see Figure 4-2). The soil matrix around Feature 1 was described as ashy, although, no charcoal was in association with this rock accumulation. An area of discolored sediment, presumably from fire, was also noted. This feature was interpreted as a disturbed hearth. 
Table 4-1. Distribution of Artifact Classes by Unit, 41ZV197

\begin{tabular}{|c|c|c|c|c|c|c|c|c|c|c|c|c|}
\hline Prov/Unit & Bone & Charcoal & Core & Debitage & $\begin{array}{c}\text { Ground } \\
\text { Stone }\end{array}$ & Historic & $\begin{array}{l}\text { Mussel } \\
\text { Shell* }\end{array}$ & $\begin{array}{c}\text { Natural } \\
\text { Clast }\end{array}$ & \begin{tabular}{|c|} 
Projectile \\
Point
\end{tabular} & $\begin{array}{l}\text { Snail } \\
\text { Shell }\end{array}$ & $\begin{array}{c}\text { Chipped } \\
\text { Stone Tool }\end{array}$ & $\begin{array}{c}\text { Grand } \\
\text { Total }\end{array}$ \\
\hline surface & & & & 1 & & 6 & & & 1 & & 3 & 11 \\
\hline N0/W10 & & 1 & 1 & 638 & & 1 & 1 & 2 & 2 & 106 & 8 & 760 \\
\hline N05/W12 & 1 & 1 & & 365 & & 29 & 3 & & 2 & 49 & 3 & 453 \\
\hline S02/W21 & & & & 174 & & & 2 & 1 & & 79 & 1 & 257 \\
\hline $\mathrm{S} 22 / \mathrm{W} 10$ & 4 & & & 312 & 1 & 23 & 3 & & 1 & 105 & 3 & 452 \\
\hline S22/W18 & & 2 & & 416 & & 11 & 6 & & & 117 & 4 & 556 \\
\hline Grand Total & 5 & 4 & 1 & 1906 & 1 & 70 & 15 & 3 & 6 & 456 & 22 & 2489 \\
\hline
\end{tabular}

*Numbers in Mussel Shell column indicate number of proveniences mussel shell was recovered from, not counts.

Table 4-2. Distribution of Artifact Classes by Level, 41ZV197

\begin{tabular}{|c|c|c|c|c|c|c|c|c|c|c|c|c|}
\hline Level & Bone & Charcoal & Core & Debitage & $\begin{array}{c}\text { Ground } \\
\text { Stone }\end{array}$ & Historic & $\begin{array}{c}\text { Mussel } \\
\text { Shell* }\end{array}$ & $\begin{array}{c}\text { Natural } \\
\text { Clast }\end{array}$ & $\begin{array}{c}\text { Projectile } \\
\text { Point }\end{array}$ & $\begin{array}{c}\text { Snail } \\
\text { Shell }\end{array}$ & $\begin{array}{c}\text { Chipped } \\
\text { Stone Tool }\end{array}$ & $\begin{array}{c}\text { Grand } \\
\text { Total }\end{array}$ \\
\hline surface & & & & 1 & & 6 & & & 1 & & 3 & 11 \\
\hline 1 & 2 & & & 469 & & 30 & 5 & 1 & 3 & 70 & 7 & 587 \\
\hline 2 & & & & 401 & & 25 & 2 & & 1 & 79 & 5 & 513 \\
\hline 3 & 2 & 2 & & 374 & & 8 & 3 & 1 & 1 & 138 & 1 & 530 \\
\hline 4 & 1 & 1 & 1 & 414 & 1 & 1 & 1 & 1 & & 113 & 4 & 538 \\
\hline 5 & & & & 147 & & & 2 & & & 23 & & 172 \\
\hline 6 & & 1 & & 88 & & & 2 & & & 31 & 2 & 124 \\
\hline 7 & & & & 12 & & & & & & 2 & & 14 \\
\hline Grand Total & 5 & 4 & 1 & 1906 & 1 & 70 & 15 & 3 & 6 & 456 & 22 & 2489 \\
\hline
\end{tabular}

*Numbers in Mussel Shell column indicate number of proveniences mussel shell was recovered from, not counts.

Lithic debitage $(\mathrm{n}=1,906)$ and tools (chipped stone, projectile points, ground stone; $\mathrm{n}=29$ ) were the most common materials recovered and collected from the site. Figure 4-3 presents the distribution of the average number of debitage by excavation level for the site. Note that two peaks are present, with one occurring in Level 1 and a second occurring in Level 4 . There is also a dramatic drop in the number of debitage below Level 4. Overall, the excavations produced a density of roughly 170 pieces of debitage per cubic meter of screened earth.

The six points recovered are all fragmentary. A Scallorn arrow point fragment was collected from the surface, while Level 1 contained an untypable dart point barb fragment, a Scallorn arrow point, and a Matamoros dart point. The Scallorn point was associated with Feature 1. A Marcos point was recovered in Level 2, and another untypable dart point barb fragment was recovered in Level 3. Figure 4-4 presents three of the six points, including the Marcos and Matamoros dart points and one of the Scallorn arrow points.
Figure 4-5 presents examples of some of the 18 bifaces recovered from the site. Though not shown, two cores, four flake tools, and a single uniface were also recovered. Twenty of the 28 chipped stone tools and points were from subsurface contexts, with most $(\mathrm{n}=16)$ being recovered from the upper two levels of the excavation. A sandstone metate was mapped in place in Level 4 of S22/W10. This is a slab of tabular sandstone that is maximally $398 \times 353 \mathrm{~mm}$ in dimension and $59 \mathrm{~mm}$ thick.

Only five bone fragments $(5.37 \mathrm{~g})$ were collected and all are small pieces. A single calcined long bone shaft fragment of a deer-sized mammal was collected in Level 1 of N5/ W12. A fragment of a proximal rib of a deer-sized mammal was recovered in Level 3 of S22/W10. In addition, 456 snail shells, and mussel shell fragments recovered from 15 proveniences, are present in the assemblage.

Recent and historic-period artifacts also were recovered from several units. Thirty-five pieces of glass of various 


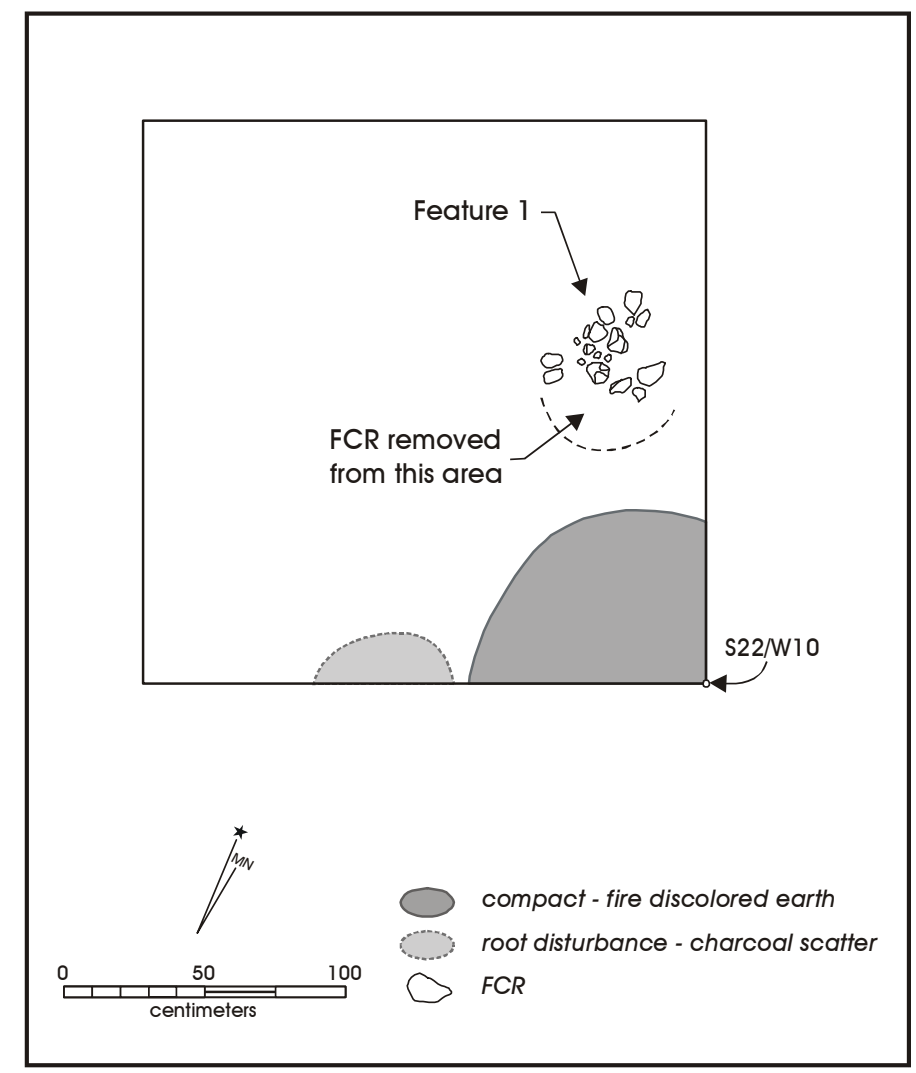

Figure 4-2. Feature 1 at 41ZV197.

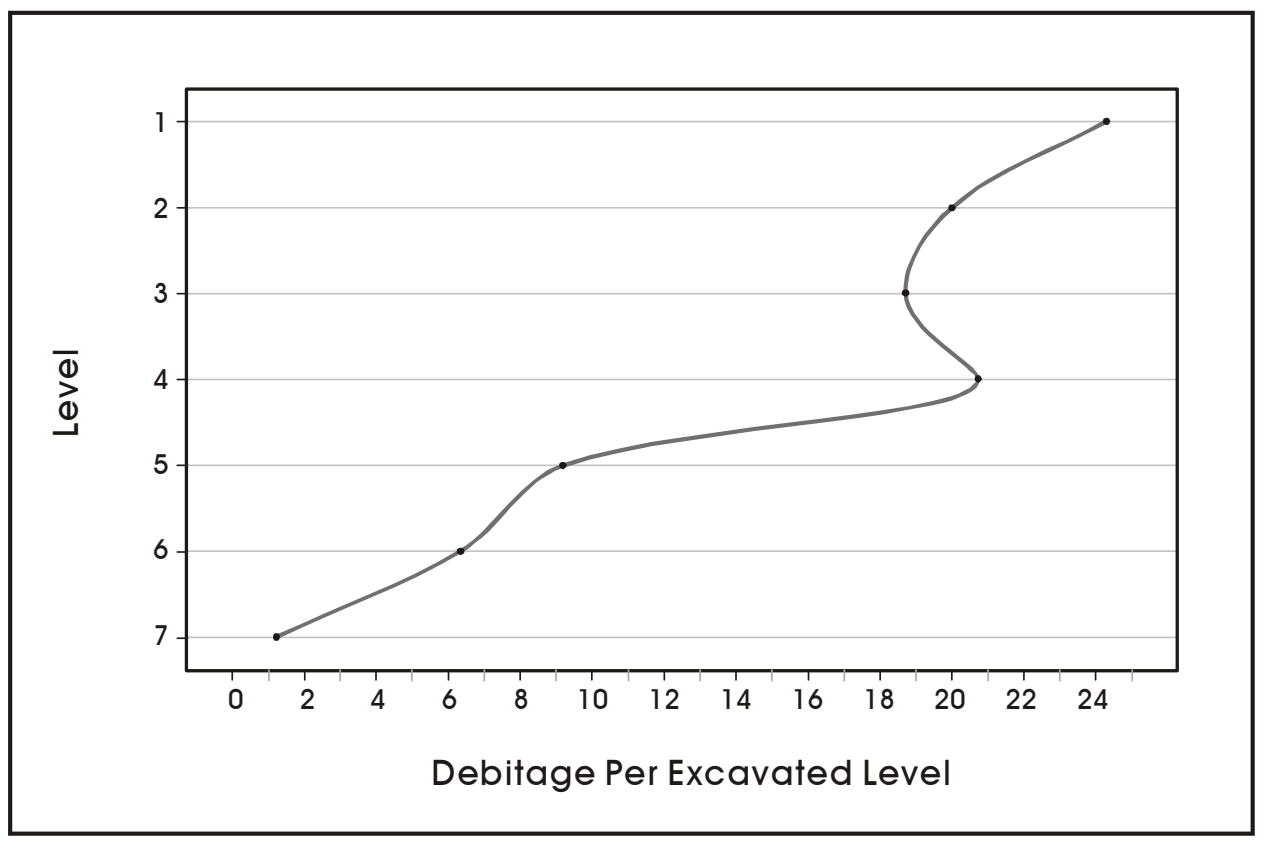

Figure 4-3. Average number of debitage recovered per excavated level at 41ZV197. 


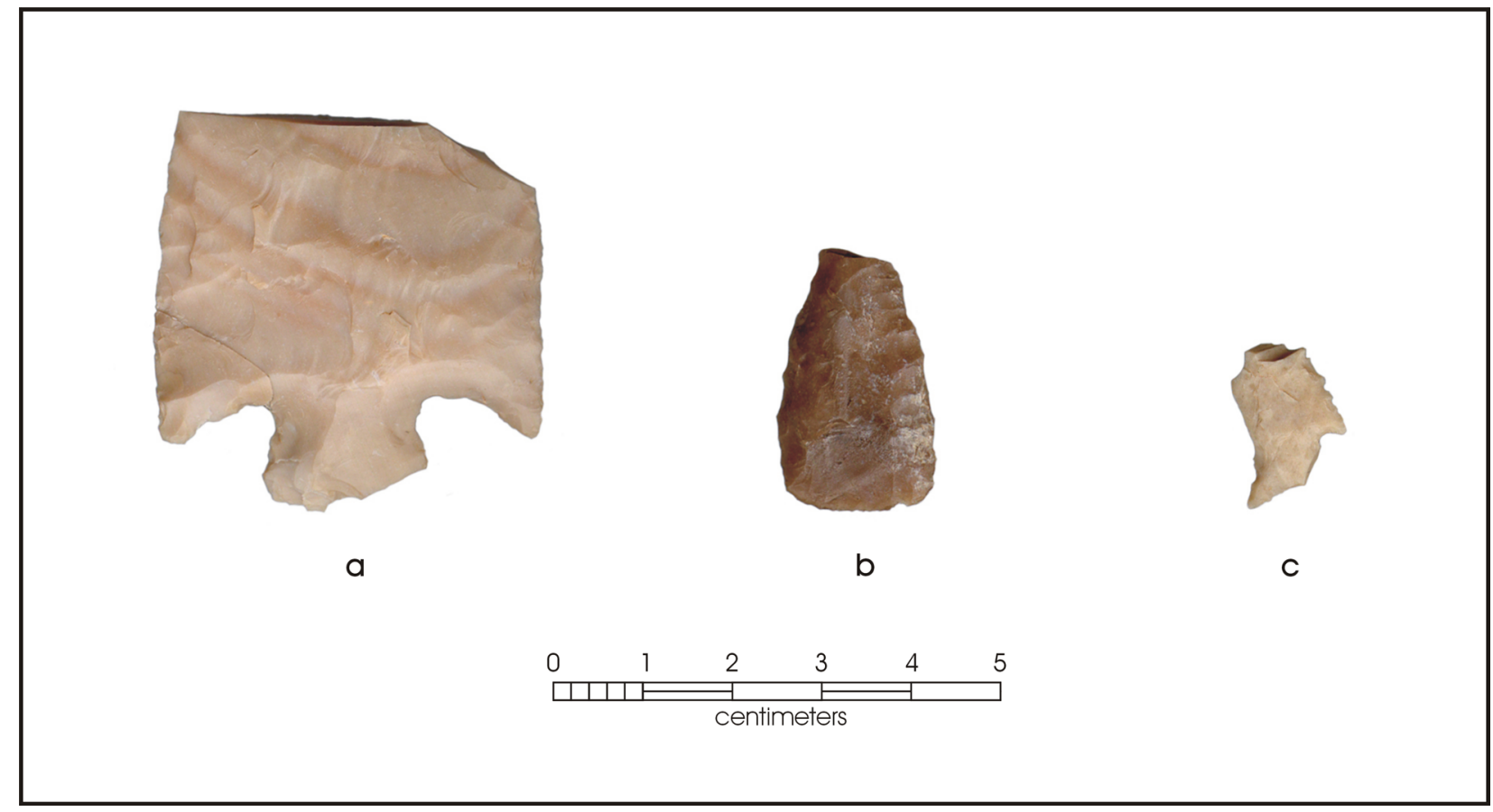

Figure 4-4. Projectile points from 41ZV197. a) Marcos; b) Matamoros; c) Scallorn.

colors, 26 pieces of metal, and nine historic ceramic sherds were collected. Most of the historic materials were found in Levels 1 and 2, but six pieces of glass and two metal fragments were provenienced to Level 3, and one piece of glass was recovered from Level 4.

While the field notes (Henderson 1981, 1982) speculated that a possible stagecoach stop was the source of the historic materials, this may be unlikely in light of the age of the ceramic fragments. The nine ceramic sherds consist of only three temporally diagnostic specimens: two Bristol Glaze which date to 1920 or later and a piece of ironstone, with the maker's mark "MELLOR and CO.", which dates from 1893-1959. Stagecoach lines operated in the region between 1851 and 1881 (Stever 2004).

\section{Summary}

Results of testing conducted by TxDOT archeologists Crawford and Henderson in 1982 at 41ZV197 suggest that the site has both Late Prehistoric and Late Archaic materials, along with historic materials, present. No clear vertical separation exists between these occupations. While the number of diagnostic points is limited, Late Prehistoric and Late Archaic projectile point forms occur within the same levels. Historic material is also present down to Level 4, although it is concentrated in the upper two levels. While the distribution of lithic debitage suggests the possibility that two peaks may be present, the peaks are not clearly separated and neither peak can be associated with a temporal period. The horizontal distribution of projectile points indicates that three of the dart points were found on the north side of FM 481 while the only arrow point found in a buried context came from south of the road. The other arrow point was found on surface, but we have not been able to determine which side of the road. While this pattern is suggestive of the horizontal spatial differentiation of components often suggested for South Texas (Hester 1995), the sample size is simply too small to evaluate this pattern statistically.

\section{$41 Z V 198$}

Site 41ZV198 is located on the western bank of Turkey Creek (see Figure 1-4). It is situated on a high terrace remnant at an elevation of roughly $810 \mathrm{ft}(247 \mathrm{~m})$ AMSL. The site rests on a landform described by Henderson as a knoll, but perhaps more accurately represented as the eroded margin of an alluvial terrace. The site is on Caid sandy clay loam soils, deep and well-drained soils over gently undulating surfaces. This soil is identified as an ideal zone for the growth of native grasses and occasional stands of mesquite trees or woody shrubs (Stevens and Arriaga 1985). 


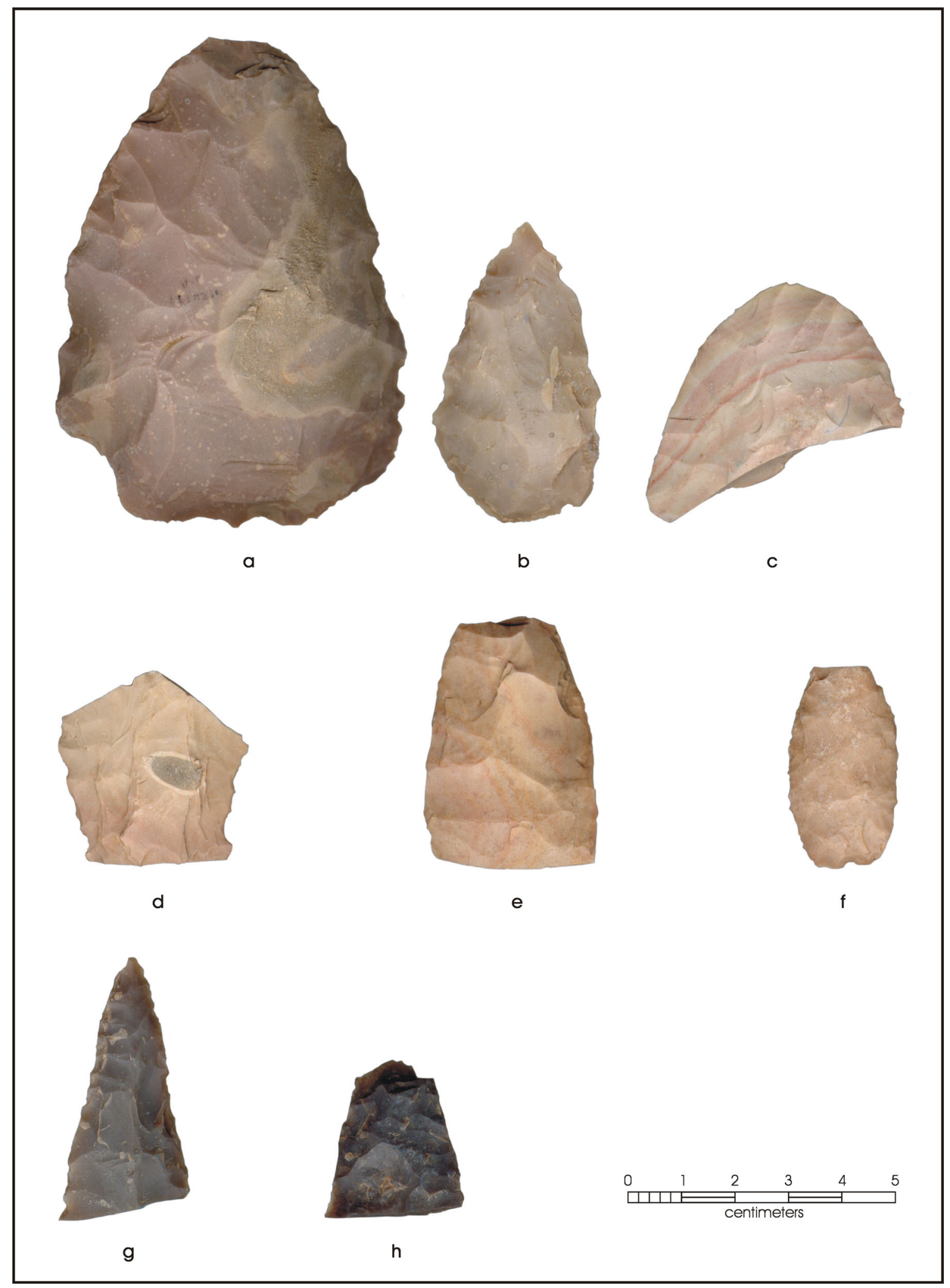

Figure 4-5. Selected bifaces from 41ZV197. 
Crawford originally recorded 41ZV198 in 1981. The site was identified as a location with low surface visibility of burned rock and chert debitage. Henderson tested the site in August of 1982. Neither Henderson nor Crawford clearly identified the site boundaries, in part because of the heavy vegetation cover. At the time of Henderson's work, the site had been mechanically impacted by road construction activities and several areas were noted as being extremely eroded. A recent revisit to this area was performed by SWCA in June 2002 (O'Farrell and Miller 2002), although they were unaware that the location was a recorded site because of an error in the Texas Archeological Sites Atlas that places the site in Limestone County. That investigation included examination of the site surface and two backhoe trenches.
They noted the area as heavily disturbed by road construction and utility work, and suggested that the area within the current right-of-way had no research potential. No subsurface remains were identified.

\section{Fieldwork}

Five test units were excavated at 41ZV198 (Figure 4-6). Information on the sketch maps indicates that test excavations were placed on both sides of the existing road and that the area examined was most likely near the eastern boundary of site 41ZV198. Roughly $92.751-\mathrm{m}^{2}$ levels were screened at this site (ca. $9.275 \mathrm{~m}^{3}$ ). While one 1 -x-2-m test unit was excavated down to $120 \mathrm{cmbs}$, most of the

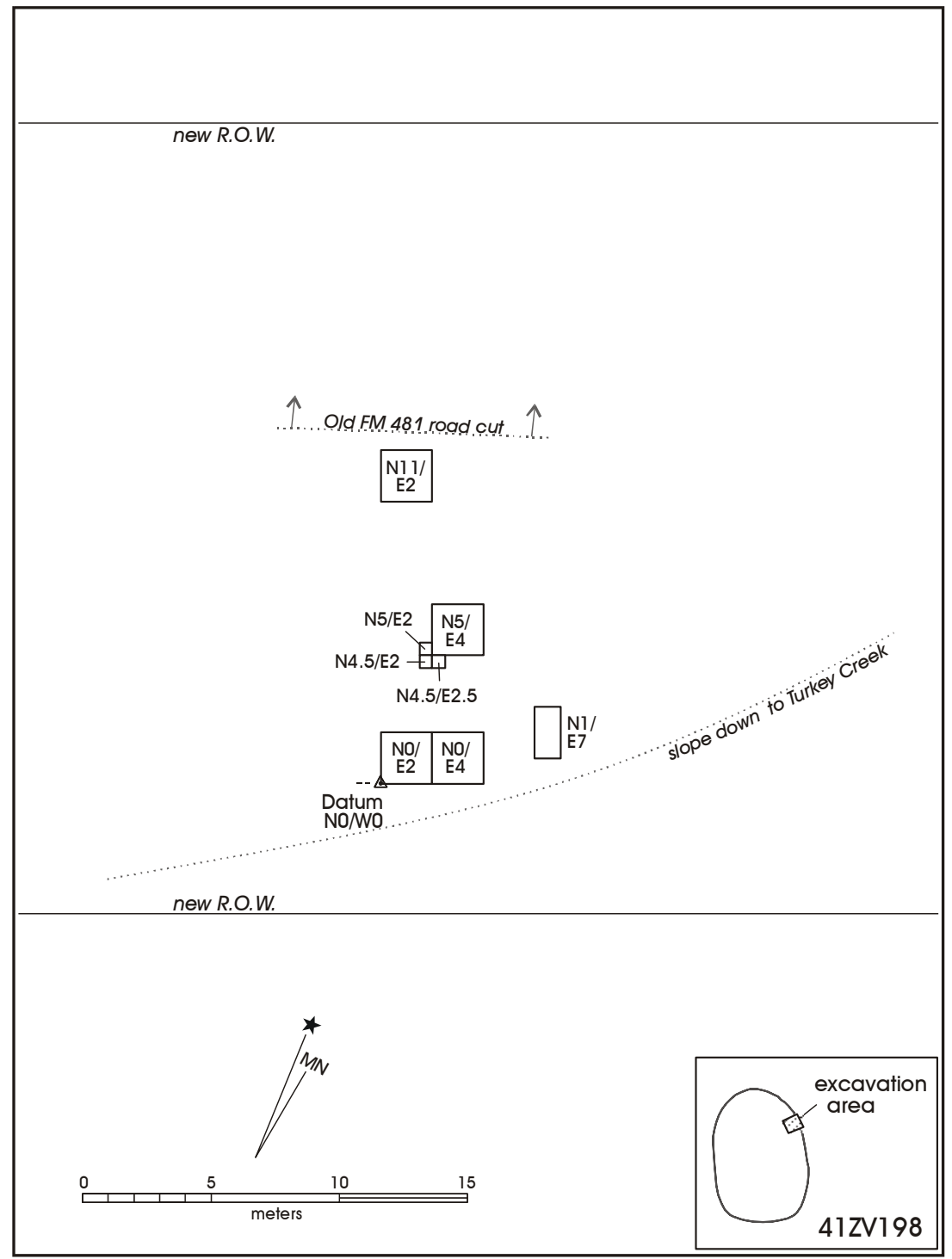

Figure 4-6. Excavation units at 41ZV198. 
excavation did not exceed $40 \mathrm{cmbs}$. Seventy-two percent of the screened sediment was removed from this upper $40 \mathrm{~cm}$. Four features, three projectile points, 215 pieces of debitage, four bifaces, and one edge modified flake were recovered (Tables 4-3 and 4-4). In addition, 51 pieces of bone, a small amount of mussel shell from four proveniences, and 487 snail shells were collected. Only a single historic artifact, a piece of metal, was recovered from the excavation. Finally, 14 charcoal samples were also recovered from the site.

Feature 1 was found in the northwestern quadrant of $\mathrm{N} 0$ / E2. The feature was identified at Level 2, though samples associated with the feature are recorded down to Level 4. While no drawing of the feature exists, a Polaroid photograph is present (Figure 4-7). Feature 1 appears to be a circular, tightly clustered group of rocks that are 10-20 $\mathrm{cm}$ in maximum size. From the photographic image, Feature
1 is roughly $60 \mathrm{~cm}$ in its north-south dimension. Several charcoal samples were collected from the feature. Individual charcoal pieces from three of these samples, all from Level 4, were submitted by CAR for dating. Sample UGA \#12694 was identified as coming from the northwest quadrant of the 2-x-2-m unit, though it was not specifically assigned to Feature 1. The sample returned a corrected date of $1570 \pm$ 40 BP (see Appendix A). The date calibrates, at one-sigma, to A.D. 435 to 535 (two-sigma, A.D. 410 to 600). A second sample, UGA \#12695, was identified as coming from Feature 1. The sample produced a corrected date of $940 \pm 40 \mathrm{BP}$. The calibrated date, at one-sigma, is A.D. 1020 to 1160 (twosigma, A.D. 1010 to 1190). The final sample, UGA\#12696, comes from the north wall of the unit. This sample is identified as being from Level 4 , but is not explicitly associated with Feature 1. It returned a date of $920 \pm 40 \mathrm{BP}$, which calibrates to a one-sigma range of A.D. 1030 to 1170

Table 4-3. Distribution of Artifact Classes by Unit, 41ZV198

\begin{tabular}{|c|c|c|c|c|c|c|c|c|c|c|c|}
\hline Prov/Unit & Bone & $\begin{array}{c}\text { Burned } \\
\text { Rock }\end{array}$ & Charcoal & Debitage & Historic & $\begin{array}{c}\text { Mussel } \\
\text { Shell* }\end{array}$ & $\begin{array}{c}\text { Natural } \\
\text { Clast }\end{array}$ & $\begin{array}{c}\text { Projectile } \\
\text { Point }\end{array}$ & $\begin{array}{l}\text { Snail } \\
\text { Shell }\end{array}$ & $\begin{array}{c}\text { Chipped } \\
\text { Stone Tool }\end{array}$ & $\begin{array}{c}\text { Grand } \\
\text { Total }\end{array}$ \\
\hline surface & 28 & & & & & & & 1 & & & 29 \\
\hline N0/E02 & 15 & 5 & 7 & 43 & 1 & & 1 & & 64 & 1 & 137 \\
\hline N0/E04 & & & 3 & 22 & & 1 & 1 & 1 & 91 & & 119 \\
\hline N0/E07 & & & & 9 & & & & & 6 & & 15 \\
\hline N01/E07 & 4 & & 1 & 77 & & 1 & & & 33 & & 116 \\
\hline N05/E04 & 4 & 2 & 2 & 40 & & 2 & & 1 & 83 & 4 & 138 \\
\hline N11/E02 & & 1 & 1 & 21 & & & & & 210 & & 233 \\
\hline S01/E03, Fill around F-4 & & & & 3 & & & & & & & 3 \\
\hline Grand Total & 51 & 8 & 14 & 215 & 1 & 4 & 2 & 3 & 487 & 5 & 790 \\
\hline
\end{tabular}

*Numbers in Mussel Shell column indicate number of proveniences mussel shell was recovered from, not counts.

Table 4-4. Distribution of Artifact Classes by Level, 41ZV198

\begin{tabular}{|c|c|c|c|c|c|c|c|c|c|c|c|}
\hline Level & Bone & $\begin{array}{c}\text { Burned } \\
\text { Rock }\end{array}$ & Charcoal & Debitage & Historic & $\begin{array}{c}\text { Mussel } \\
\text { Shell* }\end{array}$ & $\begin{array}{c}\text { Natural } \\
\text { Clast }\end{array}$ & $\begin{array}{c}\text { Projectile } \\
\text { Point }\end{array}$ & $\begin{array}{c}\text { Snail } \\
\text { Shell }\end{array}$ & $\begin{array}{c}\text { Chipped } \\
\text { Stone Tool }\end{array}$ & $\begin{array}{c}\text { Grand } \\
\text { Total }\end{array}$ \\
\hline surface & 34 & & & & & & & 1 & & & 35 \\
\hline 1 & 6 & & 2 & 50 & & 1 & 1 & 1 & 63 & 2 & 126 \\
\hline 2 & & 2 & 2 & 43 & 1 & 2 & & & 169 & 1 & 220 \\
\hline 3 & & & 3 & 16 & & & & 1 & 96 & & 116 \\
\hline 4 & 7 & 6 & 5 & 23 & & & 1 & & 97 & & 139 \\
\hline 5 & 4 & & & 30 & & & & & 20 & & 54 \\
\hline 6 & & & 1 & 26 & & & & & 21 & 1 & 49 \\
\hline 7 & & & 1 & 14 & & 1 & & & 8 & 1 & 25 \\
\hline 8 & & & & 9 & & & & & 4 & & 13 \\
\hline 9 & & & & 3 & & & & & 8 & & 11 \\
\hline 11 & & & & 1 & & & & & & & 1 \\
\hline 12 & & & & & & & & & 1 & & \\
\hline Grand Total & 51 & 8 & 14 & 215 & 1 & 4 & 2 & 3 & 487 & 5 & 790 \\
\hline
\end{tabular}

*Numbers in Mussel Shell column indicate number of proveniences mussel shell was recovered from, not counts. 


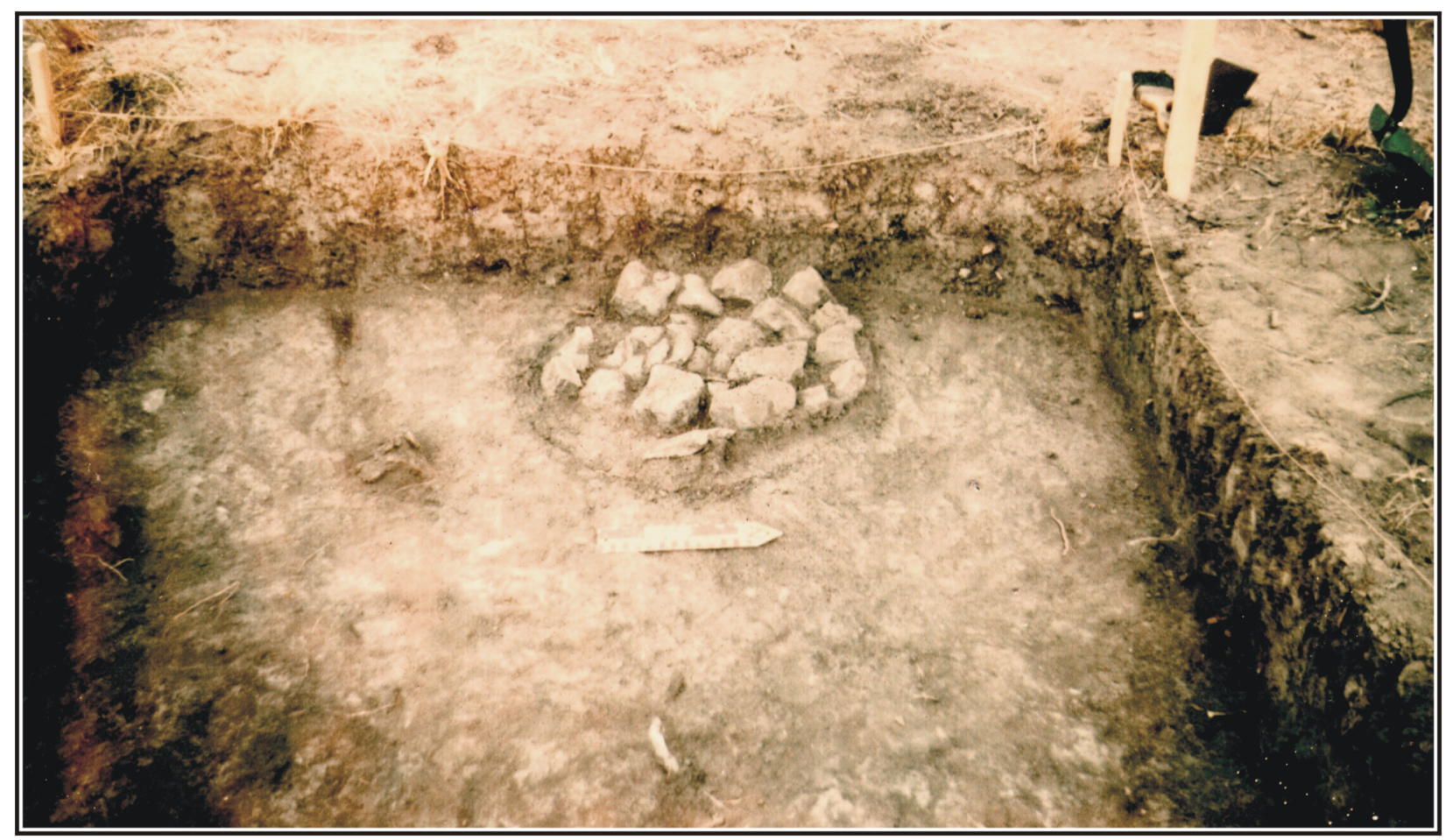

Figure 4-7. Feature 1 at 41ZV198.

(two-sigma, A.D. 1020 to 1220). Two of the samples (UGA \#12695 and UGA \#12696) overlap and suggest that the feature is likely to be Late Prehistoric in age. These two samples include the only sample explicitly listed for Feature 1. The third sample (UGA \#12694), however, suggests a Late Archaic age for this level, although it is not in direct association with the feature. No projectile points that might help sort out the dating were recovered from this excavation block. Finally, note that several deer-sized cranial fragments and a long bone fragment were found near Feature 1 and are probably associated with this feature.

Feature 2, a burned rock cluster, was encountered in the southwestern corner of N5/E4, Level 1. Some of the northeastern rocks of this feature were shoveled out before the feature was recognized. This rock accumulation is described as a small, disturbed hearth. An additional three 50-X-50-cm quadrants were opened around the southwestern corner to fully expose Feature 2 . These units were excavated to the base of Level 1 (Figure 4-8). Feature 2 is a roughly ovoid accumulation of mostly small $(5-8 \mathrm{~cm})$ and some larger $(10-17 \mathrm{~cm})$ rocks, $40 \mathrm{~cm}$ north-south by $35 \mathrm{~cm}$ eastwest. One charcoal sample was collected from within this feature and a single piece of that sample was submitted for dating. Sample UGA \#12693 returned a corrected date of

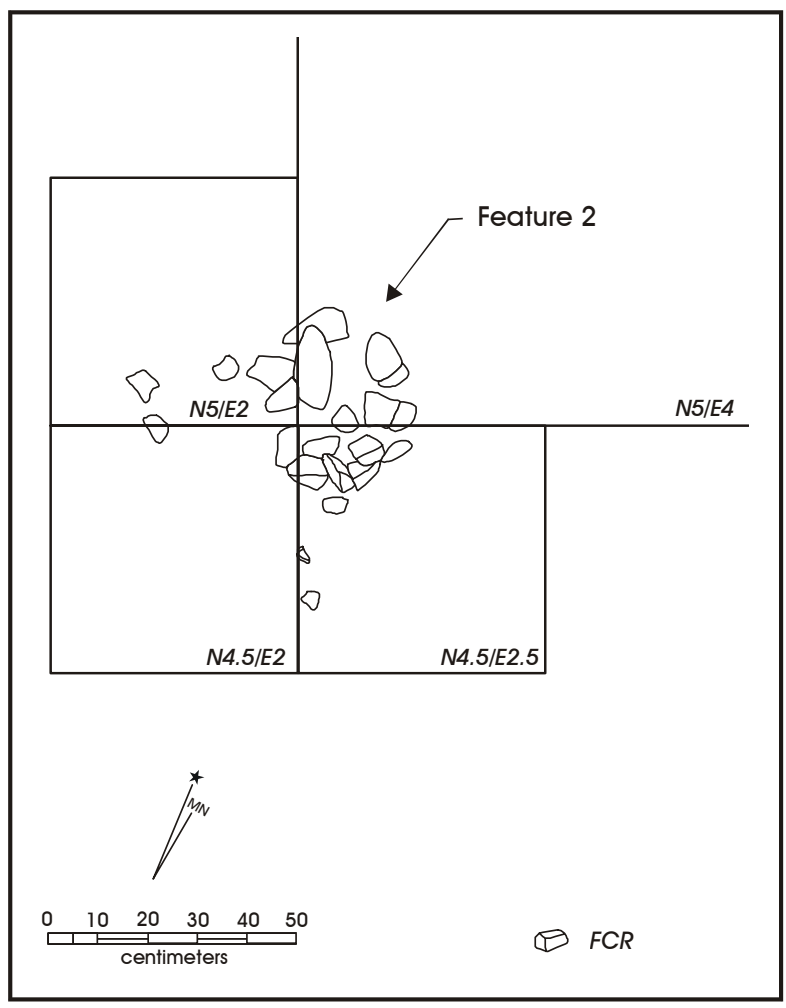

Figure 4-8. Feature 2 at 41ZV198. 
$730 \pm 40$ BP. At one-sigma, the date calibrates to A.D. 1250 to 1300 (two-sigma, A.D. 1210 to 1390), suggesting that the feature is Late Prehistoric in age.

Feature 3 was identified in Level 3 of N0/E2 (Figure 4-9). This is a large accumulation of burned rock in the southeastern quadrant of the unit. Because the rock extended outside of N0/E2, excavation was expanded to the east. Many fragmentary mussel shells and some charcoal were present within the burned rock distribution. This feature is described as being disturbed.

Feature 4 (Figure 4-10), a tight cluster of relatively large burned rocks, was identified in Level 2 of N0/E4 in close proximity to Feature 3 . The southwestern quadrant (N0/E3) of N0/E4 was originally excavated to expose rock assigned to Feature 3 . Those rocks would be directly adjacent to the cluster and scattered rocks mapped as Feature 4. Some scattered fire-cracked rock northwest of the main feature cluster was included in Feature 4. A dart point identified as a Frio is noted to have been associated with Feature 4. It was found in situ within Level 3 approximately $10 \mathrm{~cm}$ northeast of the hearth.

Two hundred fifteen pieces of debitage were recovered from the excavations at $41 \mathrm{ZV} 198$, an overall density of only 23.2 items per cubic meter of screened sediment. Figure 4-11 presents the average number of items recovered by level for the excavations. While the overall numbers are low, a significant peak is clearly present in the middle of the graph, with Levels 4, 5, and 6 having higher counts. As with the distribution at 41ZV197, some bimodality is present, with a slightly higher peak near the surface. Densities drop off rapidly below Level 7 .

Three projectile points were recovered from the site. Two of the projectile points are complete Frio points (Figure 4-12), suggesting a Late Archaic occupation (Turner and

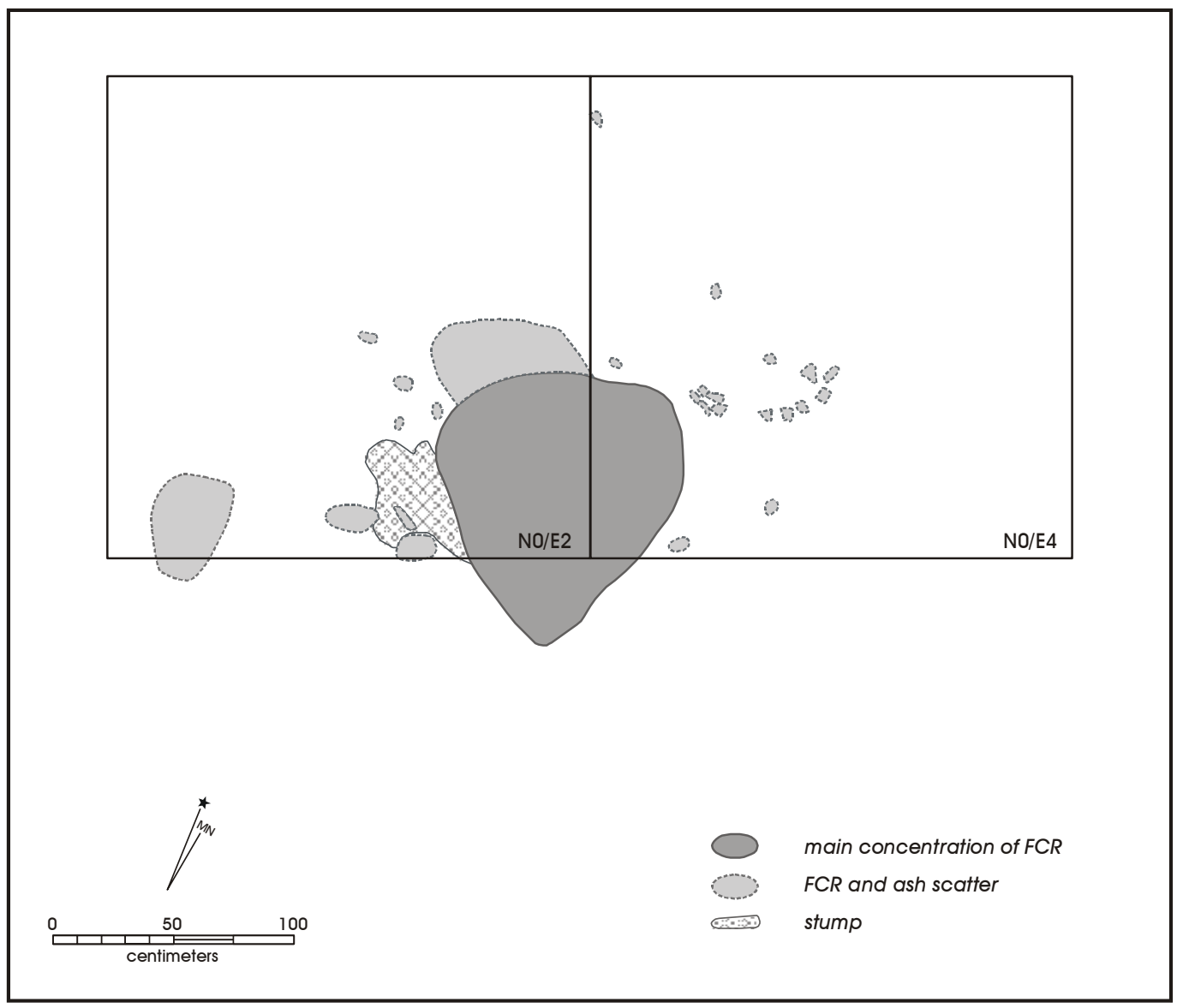

Figure 4-9. Feature 3 at 41ZV198. 


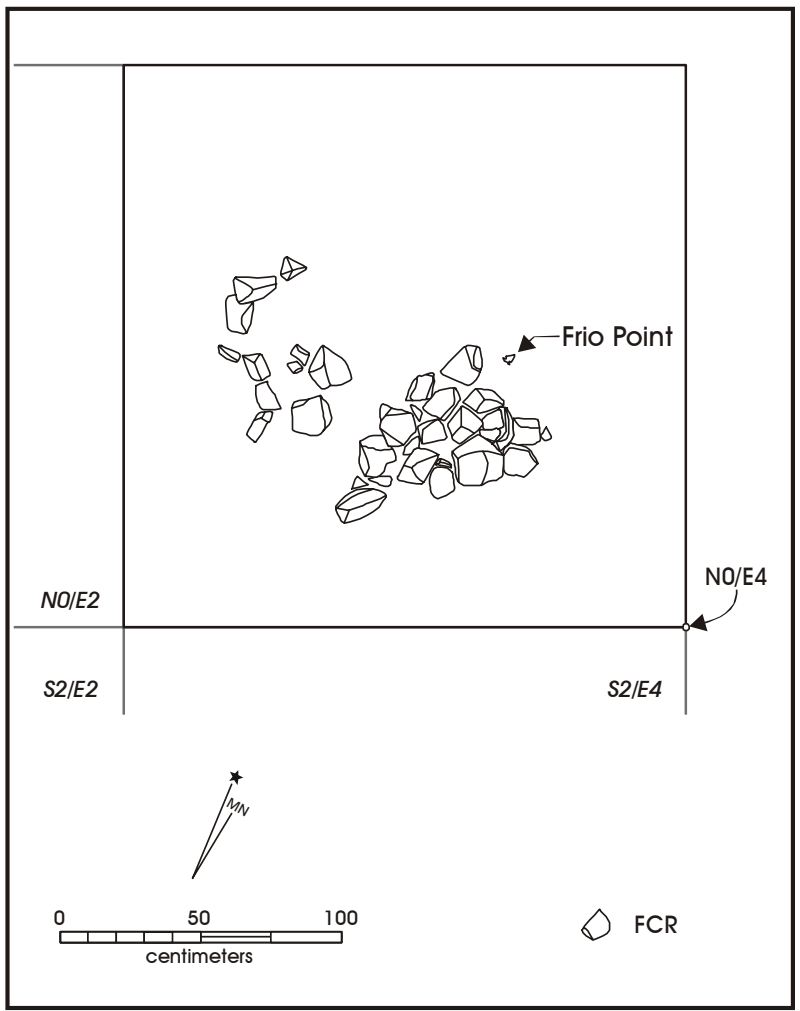

Figure 4-10. Feature 4 at $41 Z$ V198.

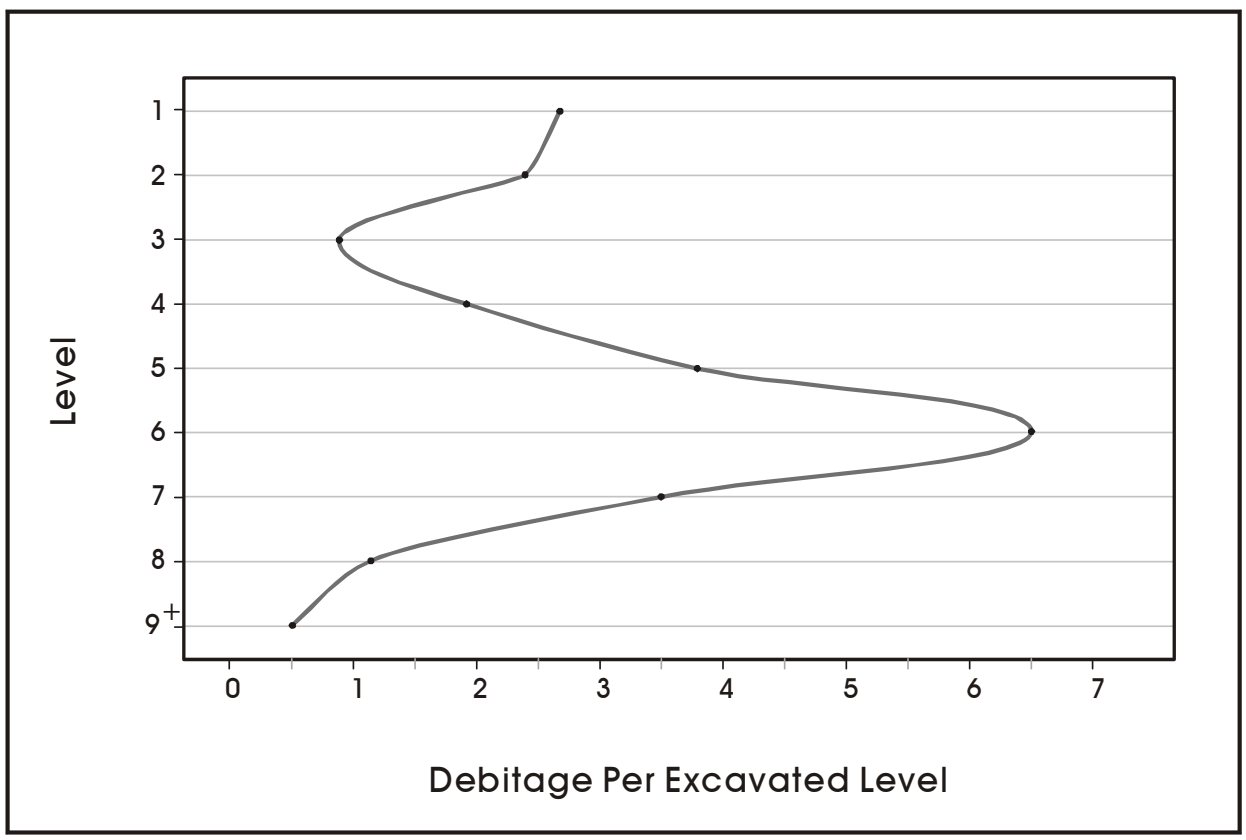

Figure 4-11. Average number of debitage recovered per excavated level at 41ZV198. 


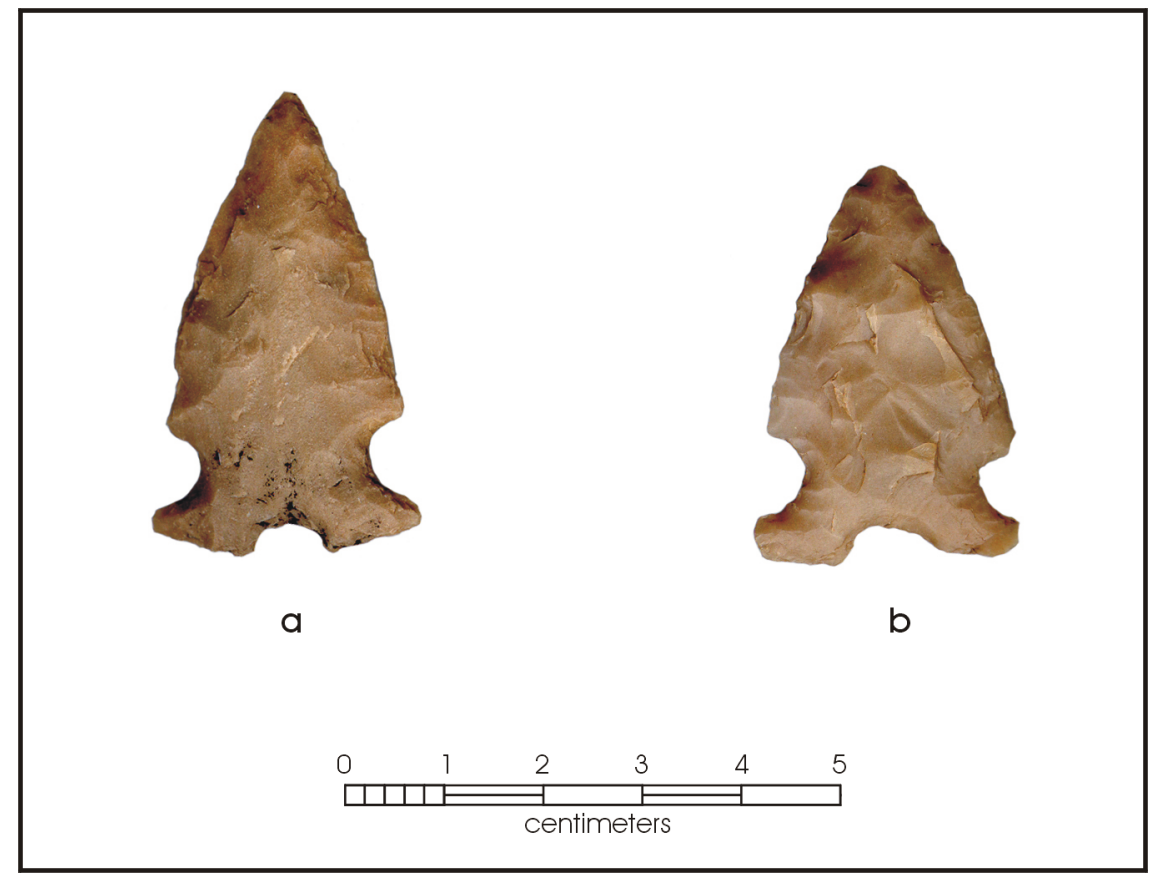

Figure 4-12. Selected projectile points from 41ZV198. a-b) Frio.

Hester 1999) dating to perhaps A.D. 200-600. The third projectile point is an untyped arrow point fragment and was recovered from the surface. One of the Frio points was collected from the surface of the site and the other was recovered in association with Feature 4. The surface point has some dark material adhering to both sides of the base (Figure 4-12, a). This may be asphaltum. Other chipped stone items recovered from the site include four bifaces and one edge modified flake.

The recovered bone sample from 41ZV198 is small with only 51 specimens $(71.02 \mathrm{~g})$ present. Twenty-two of these are fragmentary rodent bones that may be recent. Nine bones are large enough for some level of identification. Several show rodent gnawing. Five deer-sized fragments, along with a proximal radius diaphysis, were recovered near Feature 1. A proximal femoral bone shaft fragment from a bisonsized mammal was recovered from Level 5 of N1/E7. The item shows unambiguous fresh bone breaks as well as rodent gnawing. Another deer-sized diaphysis fragment exhibits extensive rodent gnawing. In addition, 487 individual snail shells and a few mussel shell fragments from four proveniences were collected. Mussel shell fragments from Level 2 of N0/E4 may have been associated with Feature 4 and appear to have been exposed to heat.

\section{Summary}

Work conducted by TxDOT in 1982 at 41ZV198 suggests that the site has both Late Prehistoric and Late Archaic materials and features. A single Late Archaic Frio dart point was recovered from the surface along with an untypable Late Prehistoric arrow point. A second Frio point came from Level 3 of N0/E4. Four radiocarbon dates also suggest some occupation during these periods. Two dates (UGA\#12695, UGA \#12696) from a depth of 30 to $40 \mathrm{cmbs}$, and possibly associated with Feature 1, suggest a Late Prehistoric use, possibly sometime between A.D. 1020 and A.D. 1170, although a third date is Late Archaic in age (A.D. 435 to 535). That third date (UGA \#12694) is within the age span suggested for Frio points, and a Frio was recovered in Level 3 from a nearby 2-x-2-m excavation unit. A fourth date, from Level 1 and associated with Feature 2, produced a Late Prehistoric date of A.D. 1250 to 1300 . The vertical distribution of lithic debitage suggests the possibility that two peaks may be present, with a peak in Level 1 and a peak in Level 6. While the Level 1 peak may be Late Prehistoric in age, the distributions are not clearly separated. The presence of a Frio point from the surface further complicates any attempt to understand the chronology at the site. Faunal material, while limited, did produce both deer- and 
bison-sized remains, with the latter having fresh bone breaks. It is unclear, however, when these faunal materials date to, given the apparent lack of integrity in the deposits.

Horizontal separation between components is nonexistent since the two buried dart points are less than five meters apart while the exact recovery location of the Frio point found on surface is not known.

\section{$41 Z V 450$}

Site 41ZV450 was initially recorded by TxDOT archeologists on transit maps at the end of the field project as two isolated burned rock features (Figure 4-13). These features were identified and mapped in September 1982 along the right-of-way of FM 481 as it begins to slope toward Dinner Creek (see Figure 1-4). The maps were drawn and tied to centerline stationing that was on the ground at the time. The stationing makes it possible to recreate the exact position of these features on a USGS topographic sheet (Greaves et al. n.d.). Greaves et al. (n.d.) originally recorded these as two separate sites (FS 3 and FS 4). The boundary of 41ZV450 was later tested and defined by SWCA (Houk et al. 2003) and the two features were combined as part of a larger site.

The eastern end of the site is bounded by Dinner Creek, a perennial drainage centrally located between Gato Creek and Turkey Creek. The majority of the site area consists of a low deposit of Caid sandy clay loam stretching along a slight ridge and dipping to the east into the deep Chacon clay loams associated with the drainage. Dinner Creek flows southerly and eventually merges with Gato Creek just over $6 \mathrm{~km}$ below the site.

The easternmost feature (FS 3 in Figure 1-4) is described as a dispersed scatter of burned limestone and chert

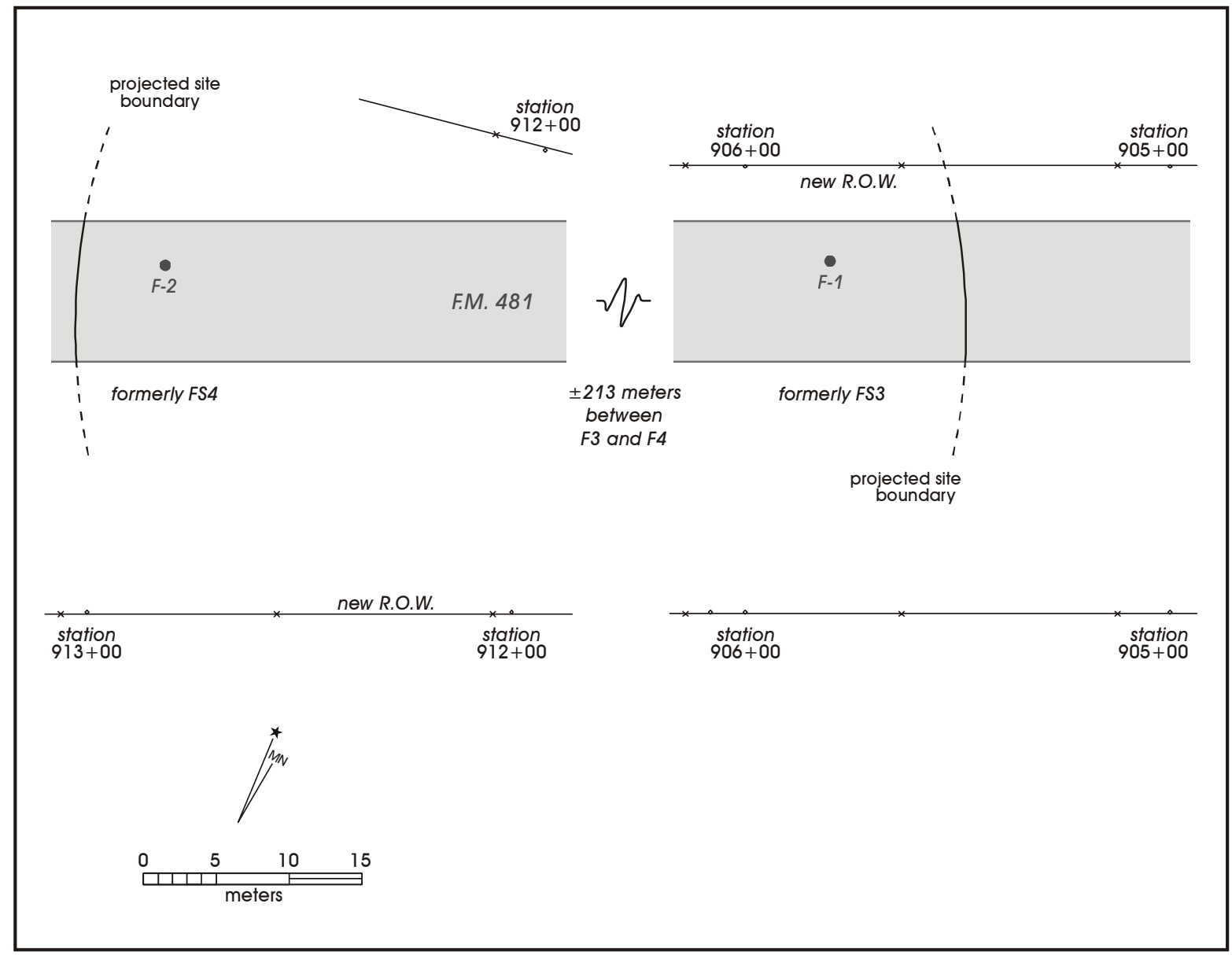

Figure 4-13. Site 41ZV450, formerly Field Sites 3 and 4. 
approximately $90 \mathrm{~cm}$ in diameter. No additional information is available about this feature or whether there were any other associated surface artifacts at this location. No evidence of any adjacent features has been identified on the sketch map of this segment of FM 481. According to station information recorded at the time of mapping, this easternmost hearth is separated by approximately $213 \mathrm{~m}$ from a second hearth (FS 4 in Figure 1-4) that forms the westernmost of the two features mapped within the FM 481 rightof-way. This second feature contained ash and charcoal staining. It was roughly basin-shaped, with an unspecified number of rocks thought to be associated with it. Some of the rocks of this second feature appeared to have been displaced from their proper orientation by heavy road traffic. This stain is identified as Feature 2 on the transit map and feature notes. No additional data about this feature, possible surface artifacts, or associated remains in adjacent portions of the right-of-way are available for a more detailed evaluation of this site. No subsurface examination was performed and no artifacts or samples collected from this site.

\section{$41 Z V 451$}

Site 41ZV451 was first identified by Henderson, TxDOT archeologist, in 1982 when she returned to the area months after the initial fieldwork. As explained in Chapter 1, she mistakenly thought that this site was 41ZV201. The location was identified as FS 5 by Greaves et al. (n.d.) based on the transit maps and stationing information, and SWCA recorded the location as 41ZV451 (Houk et al. 2003). The site is on a broad, flat upland area approximately $640 \mathrm{~m}$ south of Gato Creek at an elevation of about $810 \mathrm{ft}(247 \mathrm{~m})$ AMSL. The surface gently slopes toward Dinner Creek nearly 1,000 m to the southeast (see Figure 1-4). Site 41ZV451 is on a strip of Caid sandy clay loam which stretches along a slight ridge.

\section{Fieldwork}

Testing of the location of 41ZV451 was done in the first week of September of 1982. A transit map of the roadway segment adjacent to the areas tested was made later that same month.

Four test pits were excavated on 41ZV451 (Figure 4-14). All excavation units were referred to as test pits rather than by grid coordinates. Two of the units were 1-x-2-m in size and the other two were 2-x-2-m in size. All units were excavated to $50 \mathrm{cmbs}$. Infrequent occurrence of burned rocks is noted, but none indicated the presence of a feature. No artifacts were recovered in any of these excavations. Only two lithics, both biface fragments, were collected from the site surface.

Mapping of the roadway adjacent to where the test excavations occurred identified 23 burned rock and hearth features (Figure 4-14). These thermal features were identified as Features 3-25 on the transit map and the associated brief descriptions. A maximum distance of 103.63 $m$ between the farthest features offers the only quantification of the possible east-west boundary for this site. Within this portion of the roadway, a density of 2.88 features per 100 $\mathrm{m}^{2}$ is present.

\section{Summary}

Little can be said regarding site 41ZV451. No chipped stone artifacts were recovered from subsurface contexts, and no diagnostics are present in the collection. The two bifaces were collected during the mapping of the features in the road, and they lack any provenience beyond a surface designation. Note that SWCA has recently visited this site (see Houk et al. 2003).

\section{$41 Z V 226$}

As outlined in Chapter 1, site 41ZV226 has been assigned to the "hearth field" worked on by Henderson in the spring of 1982 (see also Greaves et al. n.d.). Testing of this site was done in August and September of 1982 by TxDOT archeologists. Referred to by Greaves et al. (n.d.) as two separate sites (FS 6 and FS 7 in Figure 1-4), the area of $41 Z V 226$ has been redefined by SWCA such that only a single site is present (Houk et al. 2003). Currently, the site is only defined within the roadway and adjacent right-ofway areas of FM 481 (Figure 4-15; see also Figure 1-4). There are roughly $1,280 \mathrm{~m}$ of highway right-of-way included in the site area totaling $38,980 \mathrm{~m}^{2}$ (9.63 acres).

The archeological zone is generally situated on a broad, high, level area of alluvial terrace (approximately $790 \mathrm{ft}$ [241 m] AMSL) that dips slightly to the southwest. The site follows a low ridge that overlooks Gato Creek toward the north and west. The hearth field portion (eastern two-thirds) of $41 \mathrm{ZV} 226$ is generally restricted to a linear zone of Valco clay loam stretching along the southeastern bank of the creek. The western one-third of the site, previously designated FS 7 (Greaves et al. n.d.), extends across Uvalde silty clay loams as the site drops closer to Gato Creek. 


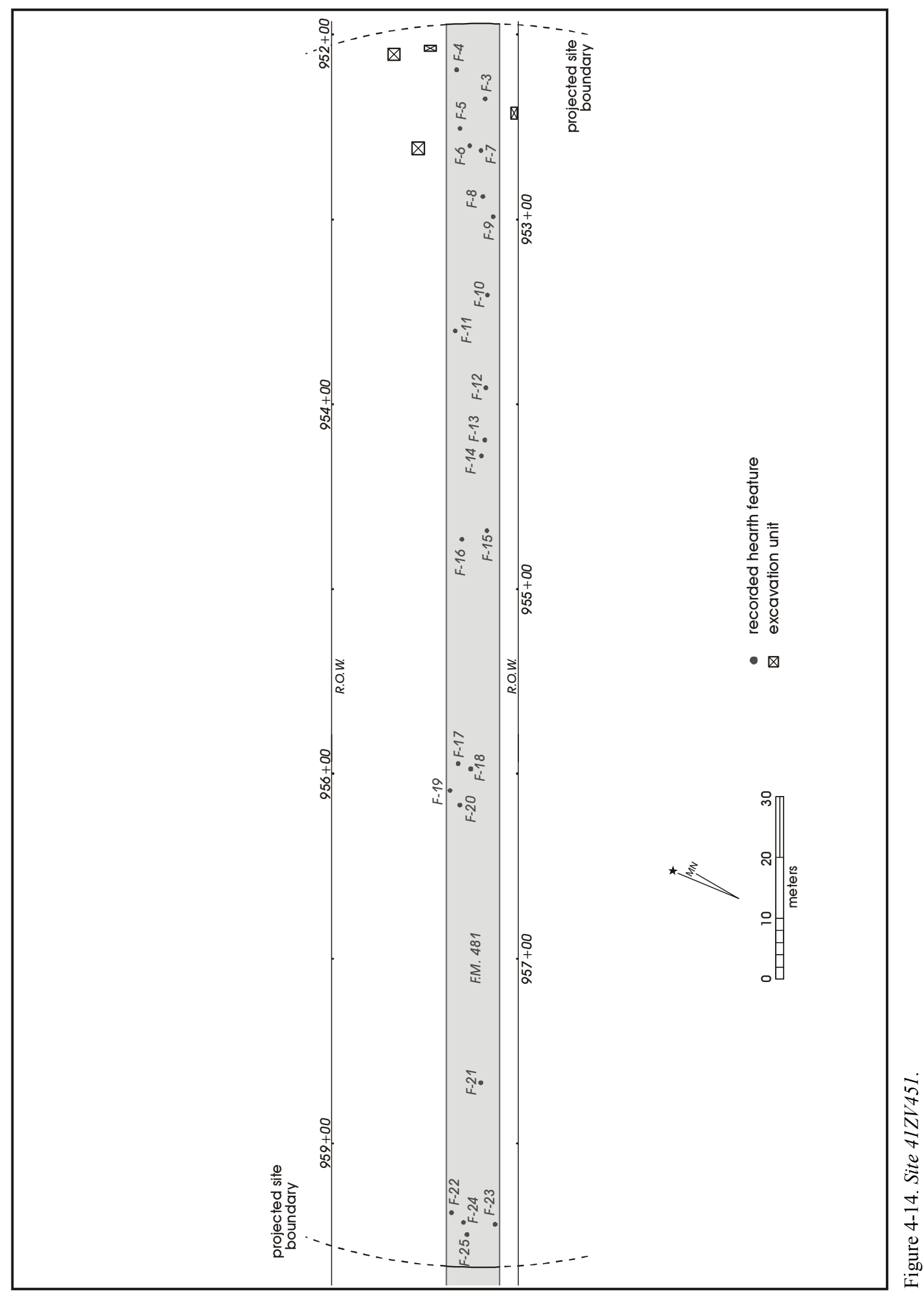




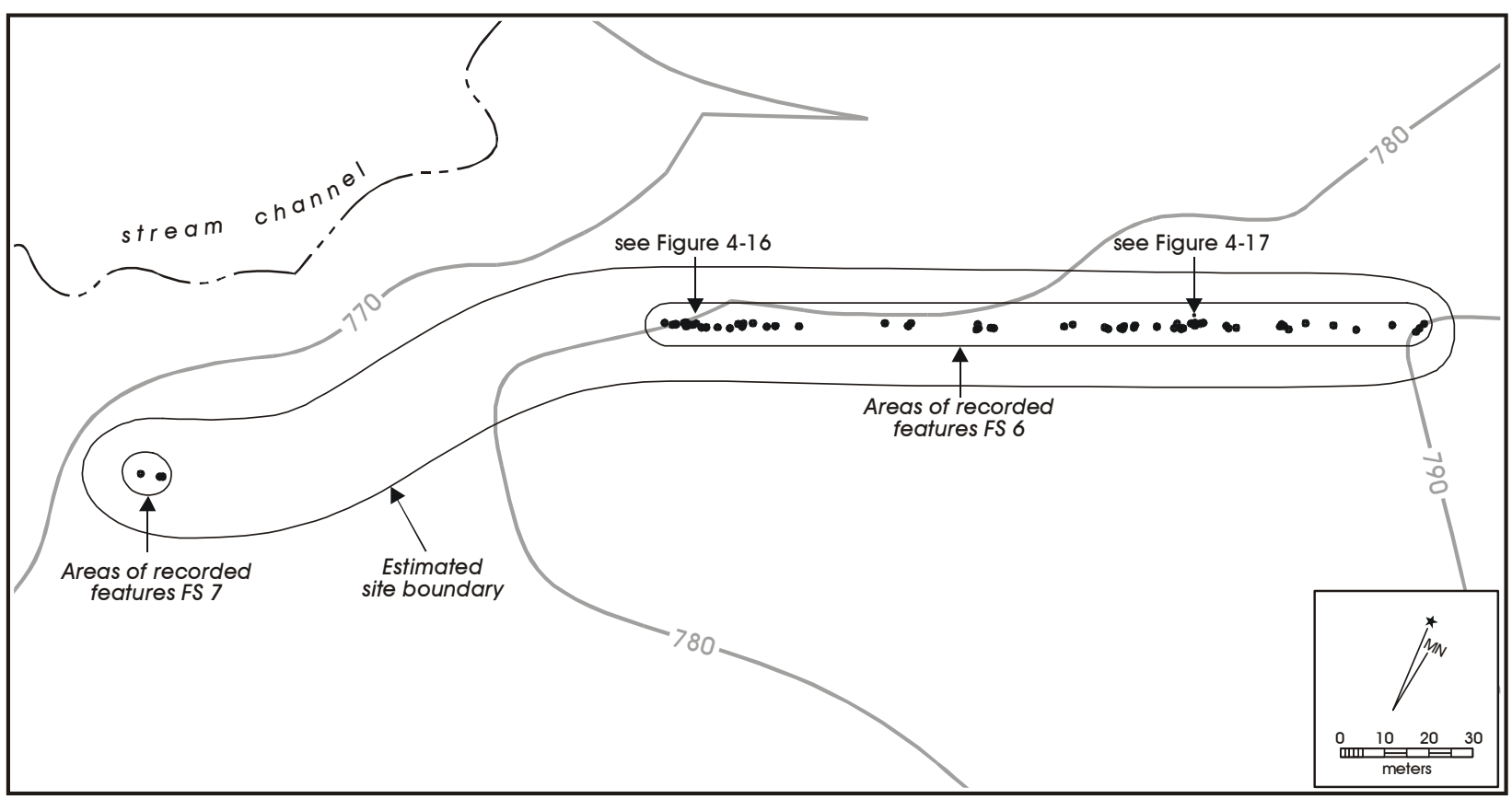

Figure 4-15. Features identified within site 41ZV226.

\section{Fieldwork}

Testing of this site was done in August and September of 1982. Fourteen 2-x-2-m test units, four 1-x-2-m units and a single $1-\mathrm{x}-1-\mathrm{m}$ shovel test were excavated during this investigation (Figure 4-16). Some of the upper $(10-15 \mathrm{~cm}$ ) sediment in several units was removed without screening as it was thought to represent recent fill deposited during road maintenance work. Also, terminal depths were not recorded in several units but we have assumed that the last level containing artifacts is the last level excavated in the unit. Our estimate, then, of the amount of screened sediment for this excavation could certainly be off as it is possible that several levels are not included in the totals. Nevertheless, we calculate that roughly $32.1 \mathrm{~m}^{3}$ of sediment were screened from this site. The deepest excavations appear to have been terminated at Level 7, with most units being excavated through Level 5. The testing produced information on 10 features and a burned area not given a formal feature designation. In addition, 3,538 pieces of debitage, eight cores, 24 projectile points, and 28 other lithic tools were collected (Tables 4-5 and 4-6). Animal bone was limited, but a small amount of mussel shell and 645 snail shells were collected. Six pieces of glass and 10 pieces of metal were also recovered.
In addition to the excavation effort, 71 feature locations were mapped in two segments in the road (see Figure 4-15). Although no samples of artifacts were collected from any of these features, some descriptive data are available. These features include stains without rocks, burned limestone and chert rock clusters, and tightly clustered burned rocks. They appear to range in size from 18 to $250 \mathrm{~cm}$ in diameter. This roadway segment, originally referred to by Greaves et al. (n.d.) as FS 6, is $698 \mathrm{~m}$ in length and represents an area of $5,375 \mathrm{~m}^{2}$ examined for features. This is the longest single portion of FM 481 with exposed hearths that were mapped. The density for this segment is 1.19 features per $100 \mathrm{~m}^{2}$. Three features (Features 90-92) were mapped along a second road segment (FS 7 in Greaves et al. n.d.). The feature density in that segment is 1.28 features per $100 \mathrm{~m}^{2}$. These density estimates, however, are not representative of the many sections of the road segment as they combine a large area containing both low-density distributions with two portions of the roadway that have moderate to very dense feature clusters. One such cluster of features is shown in Figure 4-17, and another is visible in Figure 4-16, south of the excavation units. Finally, note that a single 1-x-1-m excavation unit is shown just to the north of the hearth cluster in Figure 4-17. This unit was recorded on the transit map of this road segment, but no additional information is available on that excavation. 


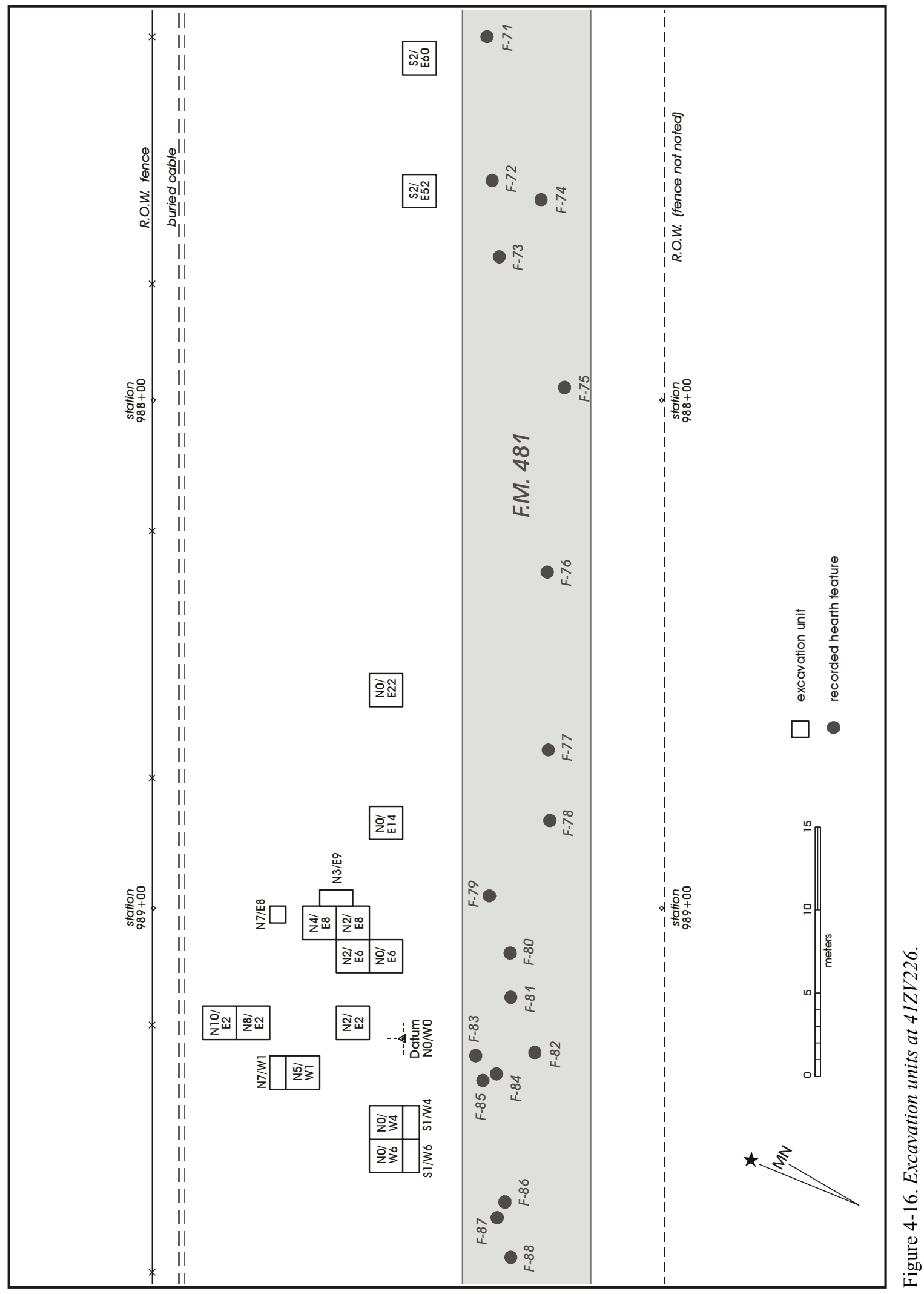




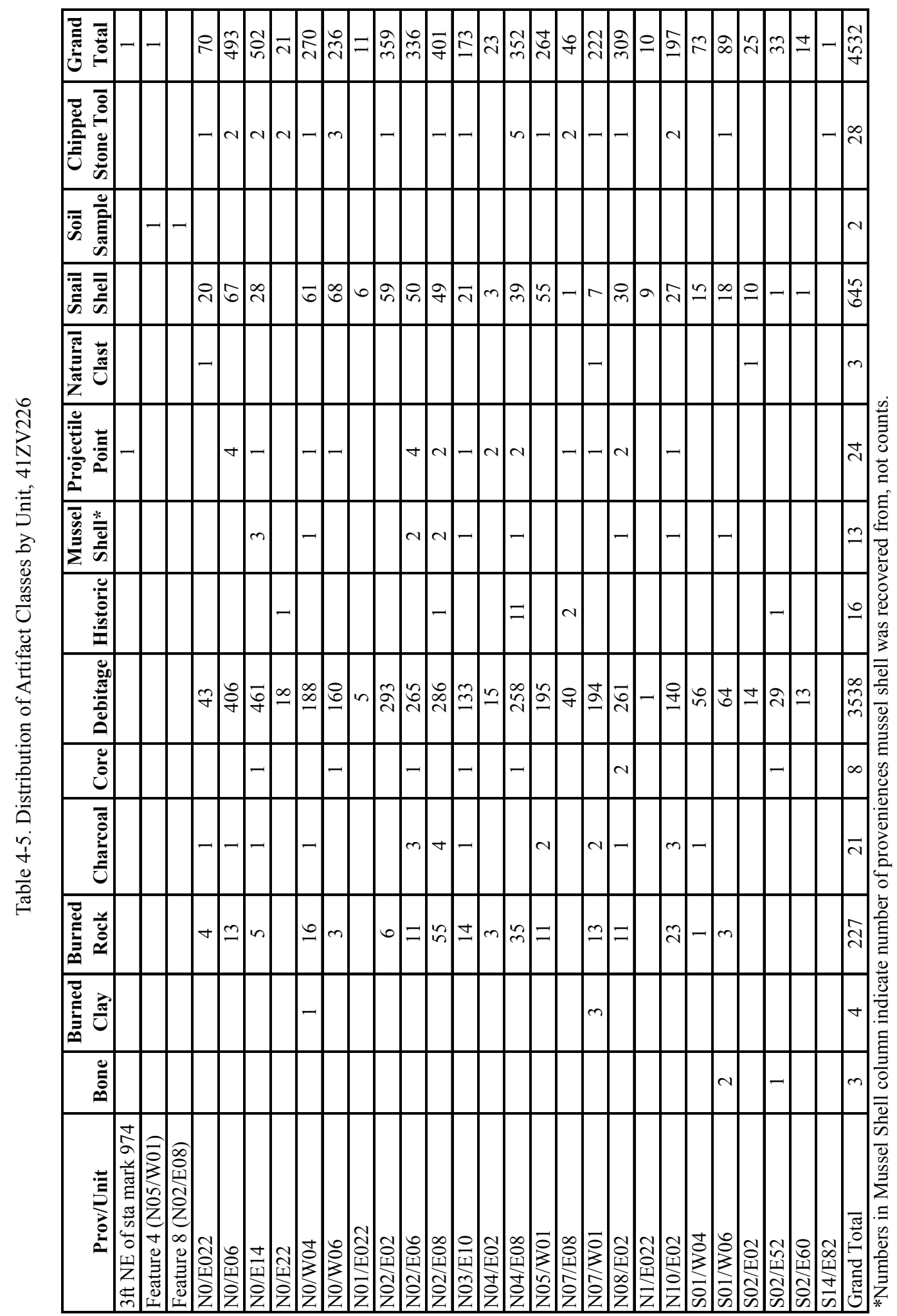


Table 4-6. Distribution of Artifact Classes by Level, 41ZV226

\begin{tabular}{|c|c|c|c|c|c|c|c|c|c|c|c|c|c|c|}
\hline Level & Bone & $\begin{array}{c}\text { Burned } \\
\text { Clay }\end{array}$ & $\begin{array}{c}\text { Burned } \\
\text { Rock }\end{array}$ & Charcoal & Core & Debitage & Historic & \begin{tabular}{|c|} 
Mussel \\
Shell*
\end{tabular} & $\begin{array}{c}\text { Projectile } \\
\text { Point } \\
\end{array}$ & $\begin{array}{c}\text { Natural } \\
\text { Clast } \\
\end{array}$ & $\begin{array}{l}\text { Snail } \\
\text { Shell }\end{array}$ & $\begin{array}{c}\text { Soil } \\
\text { Sample }\end{array}$ & \begin{tabular}{|c|} 
Chipped \\
Stone Tool
\end{tabular} & $\begin{array}{c}\text { Grand } \\
\text { Total }\end{array}$ \\
\hline surface & & & & & & & & & 1 & & & & 1 & 2 \\
\hline 1 & 3 & & 57 & 2 & 2 & 894 & 11 & 3 & 6 & & 76 & & 14 & 1068 \\
\hline 2 & & & 80 & 8 & & 1332 & 5 & 3 & 5 & & 157 & 2 & 7 & 1599 \\
\hline 3 & & 3 & 67 & 5 & 4 & 832 & & 3 & 8 & 2 & \begin{tabular}{|l|}
170 \\
\end{tabular} & & 5 & 1099 \\
\hline $3 \& 4$ & & & 1 & 1 & & 8 & & & & & 6 & & & 16 \\
\hline 4 & & 1 & 12 & 5 & 1 & 262 & & 3 & 2 & 1 & 110 & & & 397 \\
\hline 5 & & & 8 & & 1 & 174 & & 1 & 2 & & 90 & & 1 & 277 \\
\hline 6 & & & 2 & & & 31 & & & & & 33 & & & 66 \\
\hline 7 & & & & & & 5 & & & & & 3 & & & 8 \\
\hline Grand Total & 3 & 4 & 227 & 21 & 8 & 3538 & 16 & 13 & 24 & 3 & 645 & 2 & 28 & 4532 \\
\hline
\end{tabular}

*Numbers in Mussel Shell column indicate number of proveniences mussel shell was recovered from, not counts.

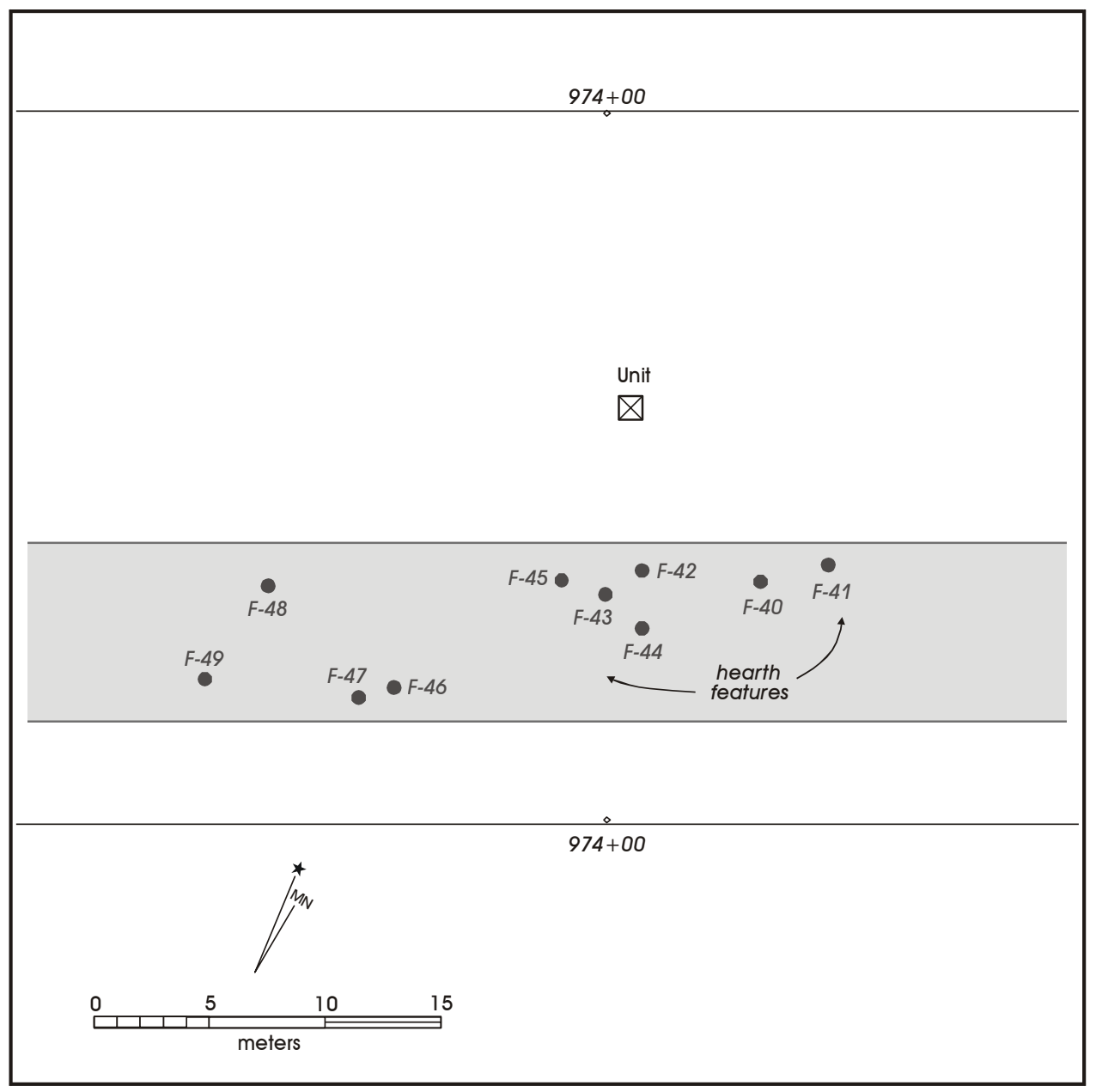

Figure 4-17. Feature distribution and unit along FM 481, site 41ZV226. 
Feature 1 was a small scatter of rock identified in Level 2 of the south-central portion of N0/W4 (Figure 4-18). This feature was roughly $40 \mathrm{~cm}$ by $20 \mathrm{~cm}$ and may have extended southward into the adjacent grid unit. The rocks are jumbled, and the feature was interpreted as a rock pile and not a hearth. A lumped charcoal sample was collected from this area. CAR submitted two individual pieces of charcoal for radiocarbon dating. The first sample, UGA\#12689, returned a corrected date of $950 \pm 40 \mathrm{BP}$ (Figure 4-19). A one-sigma calibration on that sample produced an age range of A.D. 1020 to 1160 (two-sigma, A.D. 1000 to 1190 ). The second sample, UGA \#12690, produced a corrected date of $1080 \pm$ $40 \mathrm{BP}$, and a one-sigma calibration of A.D. 890 to 1020 (twosigma, A.D. 890 to 1030). These dates suggest that the feature is Late Prehistoric in age.

Feature 2 was encountered in Level 4 of the southwestern quadrant of N0/W4. The rock distribution extended to the west and south outside of this $2-\mathrm{x}-2-\mathrm{m}$ unit, which was expanded to expose this feature. The area of the tightest clustering of rocks was distinguished as Feature 2 (Figure
4-20). The feature rested just above a caliche soil that is either bedrock or a much older soil unit. Charcoal was present, and a lumped collection of small individual pieces was made. Two of the larger pieces from this sample were submitted for dating by CAR. The samples are identified as coming form Levels 3 and 4 in S1/W4 (see Figure 4-20). Sample UGA \#12687 returned a corrected date of $610 \pm 40$ BP. At one-sigma, this date calibrates to A.D. 1300 to 1400 (two-sigma, A.D. 1209 to 1410). Sample UGA \#12688 returned a date of $680 \pm 40 \mathrm{BP}$. At one-sigma, this date calibrates to A.D. 1280 to 1390 (two-sigma, A.D. 1270 to 1400). The overlapping dates clearly identify this feature as Late Prehistoric in age.

An accumulation of burned rock visible on the surface of the southeastern quadrant of N10/E2 was designated as Feature 3 . The primary concentration of rock was roughly 40 by $50 \mathrm{~cm}$. Small burned rocks and ash extended $100 \mathrm{~cm}$ from the southeast wall of N10/E2 (Figure 4-21). Charcoal was present within the feature and a Late Prehistoric arrow point was recovered from Feature 3.

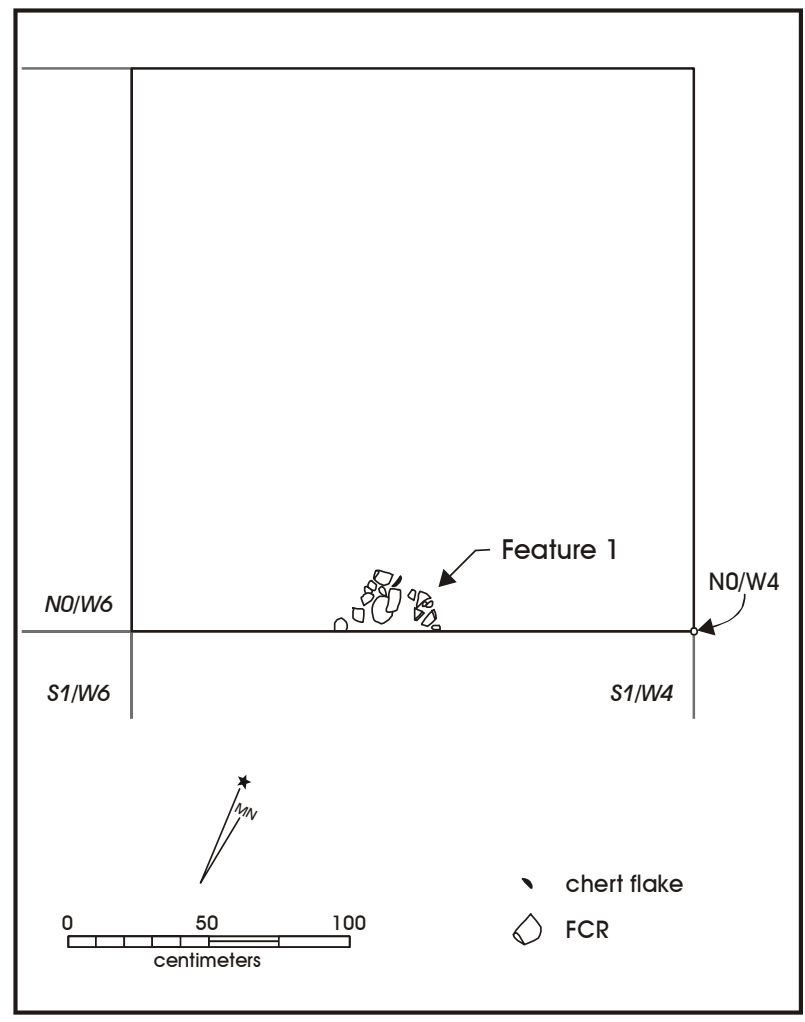

Figure 4-18. Feature 1 at 41ZV226. 


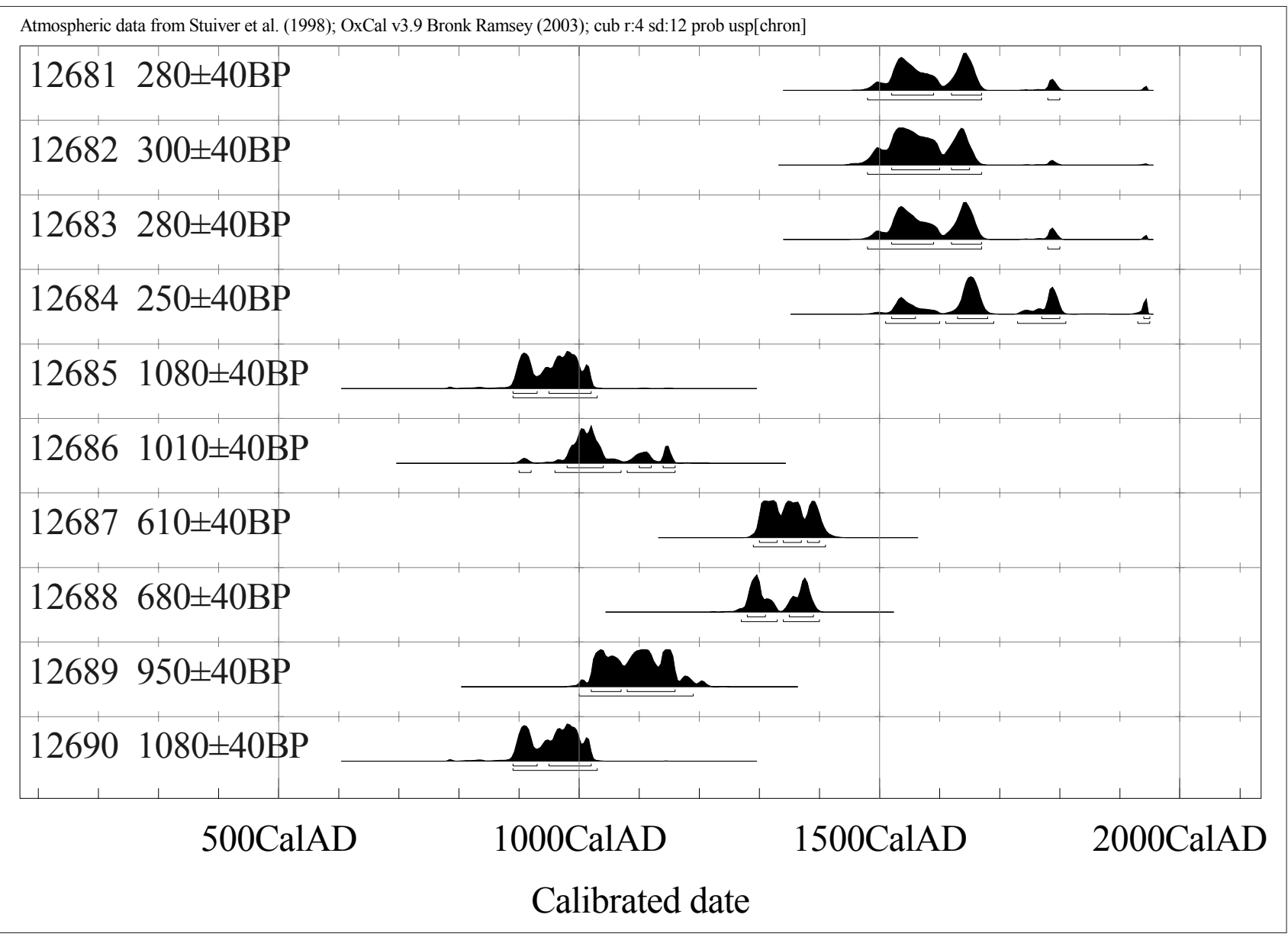

Figure 4-19. Radiocarbon dates from 41ZV226.

While no plan views exist for Features 4, 5, and 6, Figure 4-22 is a Polaroid photo that depicts all three features. Feature 4 was recognized in Level 2 of the northeastern quadrant of N5/W1. It is a roughly circular cluster of rock. Feature 5 was identified in Level 5 of the northwestern quadrant of N5/W1, though rocks associated with this feature were encountered in Level 3. Like Feature 4, Feature 5 contains burned rock, though the distribution is described as being more dispersed. Feature 6 is a cluster of burned rock first identified in the western half of Level 1 in N7/W1, adjacent to Features 4 and 5. Feature 6 was a well-defined, roughly circular accumulation of fire-cracked rock (Figure 4-22).

Feature 7 was identified in Level 3 of N2/E6. This feature was a dark gray midden zone containing abundant charcoal and fragmentary mussel shell. This feature is roughly 120 $\mathrm{cm}$ by $120 \mathrm{~cm}$ (Figure 4-23). From a lumped sample of charcoal identified as coming from Feature 7, CAR submitted two individual pieces for dating. Sample UGA \#12685 produced a corrected date of $1080 \pm 40 \mathrm{BP}$, and sample UGA $\# 12686$ dated to $1010 \pm 40 \mathrm{BP}$. At one-sigma, the first sample calibrates to A.D. 890 to 1020 (two-sigma, A.D. 890 to 1030), while the second calibrates to A.D. 980 to 1160 (two-sigma, A.D. 900 to 1160). These overlapping dates place the feature in the Late Prehistoric period.

Feature 8 , a concentration of fire-cracked rock with scattered ash and charcoal, was encountered in Levels 2 and 3 of N2/ E8. This feature was directly adjacent to Feature 9, a smaller concentration of tightly clustered burned rock at roughly the same elevation (Figure 4-24). It appears that this feature was separated from Feature 8 because the morphology implied that it was an intact hearth. Greaves et al. (n.d.) suggest that the separation between Features 8 and 9 may 


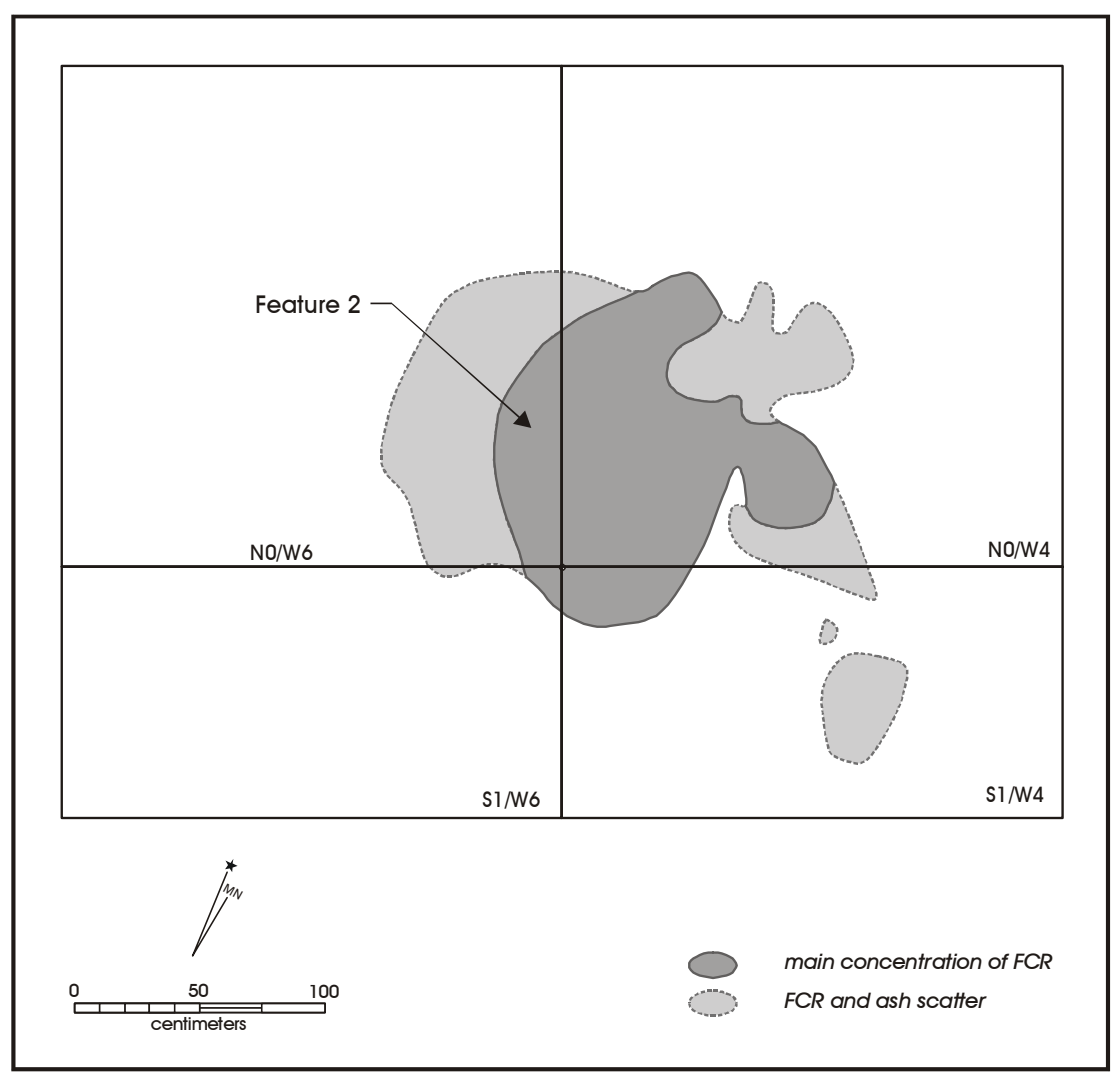

Figure 4-20. Feature 2 at 41ZV226.

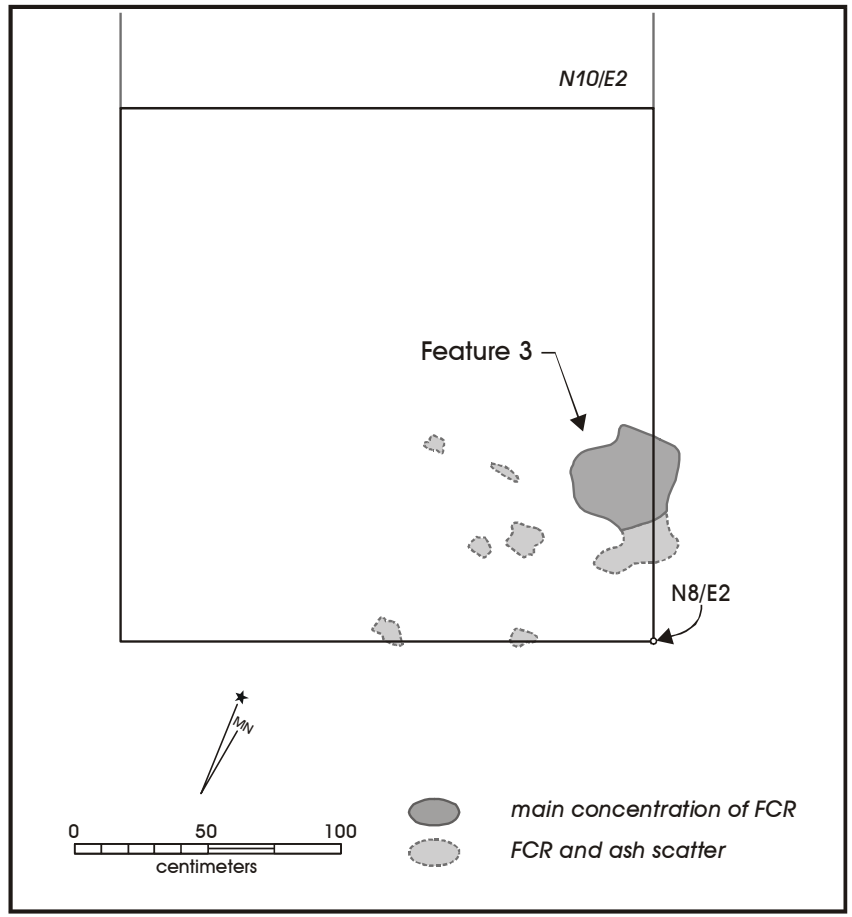

Figure 4-21. Feature 3 at 41ZV226. 


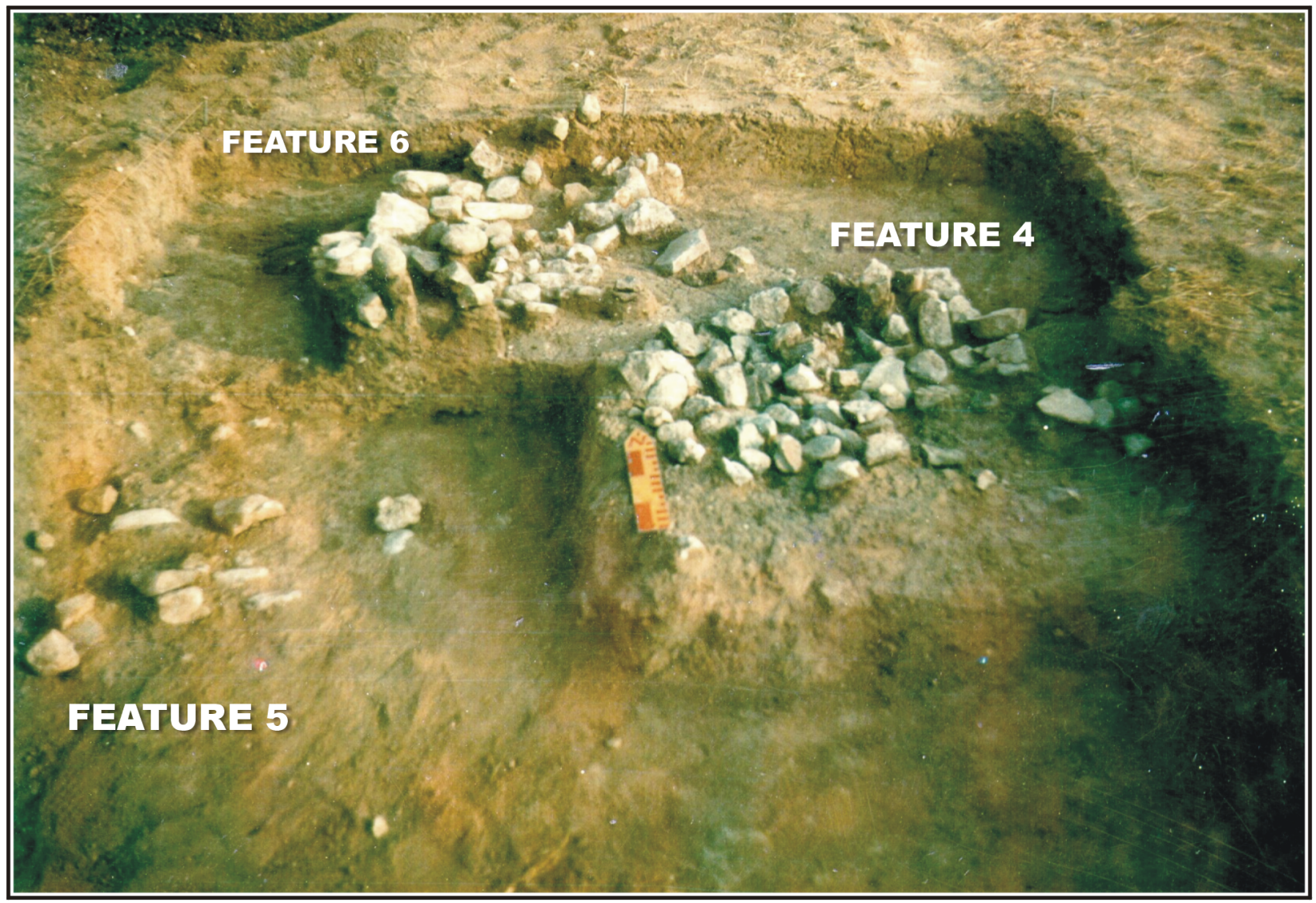

Figure 4-22. Features 4, 5, and 6 at 41ZV226.

be spurious. That assessment is based on confusion in the notes, coupled with the possibility that Feature 9 was defined after the area was excavated. CAR submitted two radiocarbon samples, each consisting of individual pieces of charcoal, which were associated with Level 2 of Feature 8. Charcoal was also submitted from Level 3 of Feature 9, samples apparently collected from a dark stain underneath the approximate center of that feature. Samples UGA \#12683 and UGA \#12684, both from Feature 8, produced corrected dates of $280 \pm 40 \mathrm{BP}$ and $250 \pm 40 \mathrm{BP}$. The first date calibrates to a range of A.D. 1520 to 1670 , while the second spans the period from A.D. 1520 to 1955 , although $65.5 \%$ of the curve falls between A.D. 1520 and 1800 (see Figure 4-19). Samples UGA \#12681 and UGA \#12682, both from Feature 9, date to a similar period. Sample UGA \#12681 produced a date of $280 \pm 40$ BP while UGA \#12682 produced a date of 300 $\pm 40 \mathrm{BP}$. The first of these calibrates to a one-sigma range of A.D. 1520 to 1670 (two-sigma, A.D. 1480 to 1800), while the second calibrates to A.D. 1520 to 1650 (two-sigma, A.D. 1480 to 1670 ). Whether these dates are from one or two features, it is clear that the age range is probably between A.D. 1520 and about 1700 , a date that is primarily in the Protohistoric period.

No information about Feature 10 is available except in a profile of the northern wall of N0/W13 (Figure 4-25). The feature is a basin-shaped anomaly approximately $24-70 \mathrm{~cm}$ below the ground surface. Five burned rocks are indicated.

During excavation of Level 3 in N0/E6, two large areas of discoloration were noted and mapped. They were not recorded as features. These two locations were identified as areas that represented in situ burning. There is no information regarding the west wall profile of N0-N2/E6 (Figure 4-26) indicating whether those burned areas are represented by the identified disturbances. The southernmost stain occupies the western portion of the center of this 2-x2 -m unit. It is roughly $90 \mathrm{~cm}$ by $60 \mathrm{~cm}$ and extends west of N0/E6. The northern burned area is in the northeastern quadrant of N0/E6 and is $76 \mathrm{~cm}$ by $52 \mathrm{~cm}$. This discolored 


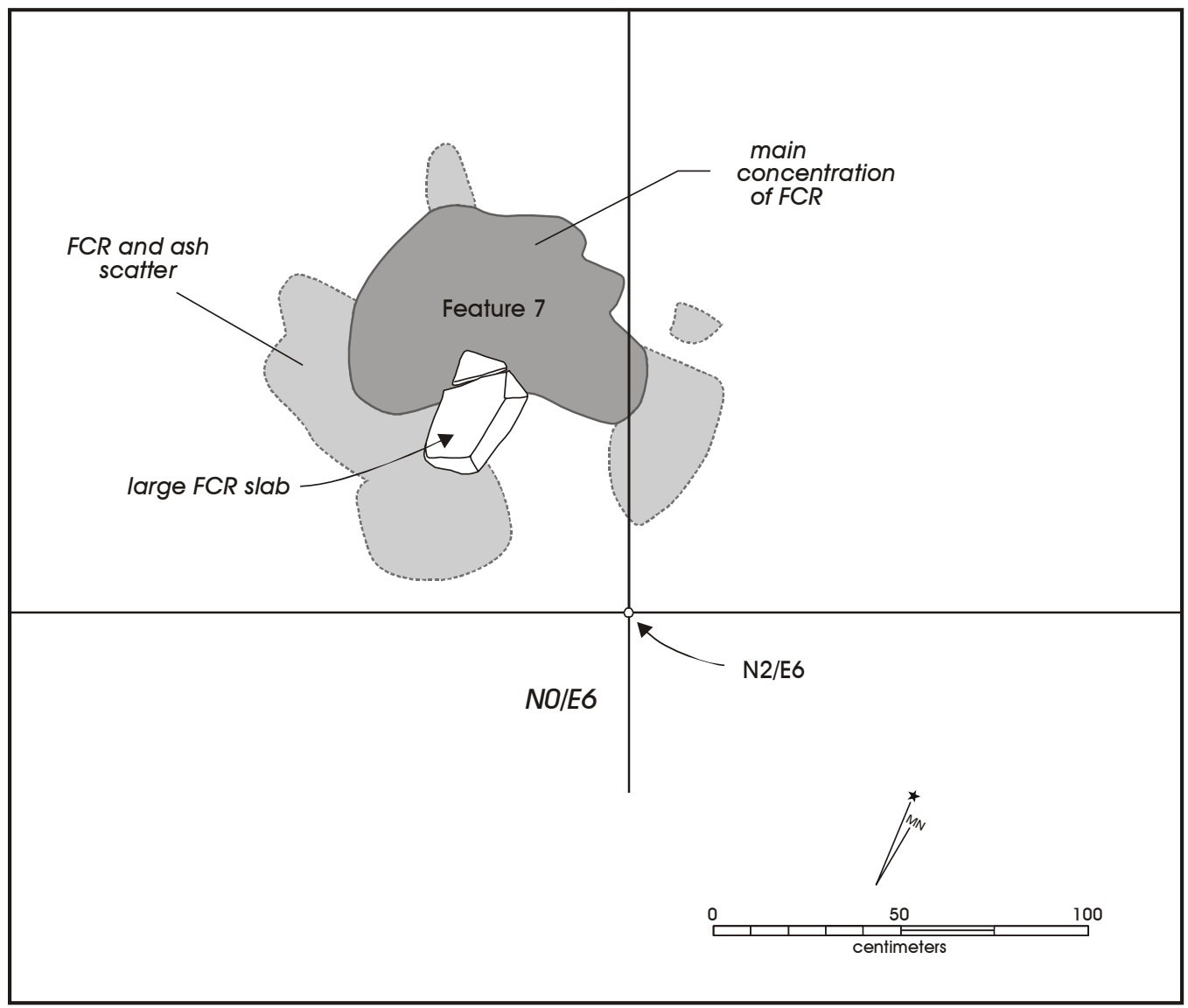

Figure 4-23. Feature 7 at 41ZV226.

area extends north into the adjacent unit. Charcoal was present in each of these areas. The nature of these deposits is not known.

The artifact sample from 41ZV226 is the largest assemblage from the testing along FM 481. This is partly because over $32 \mathrm{~m}^{3}$ of earth were screened at this site. As noted previously, 3,538 pieces of debitage were collected, along with 24 points, other tools, and cores. Focusing on debitage, the overall density is roughly 110 items per cubic meter, slightly lower than that for 41ZV197 noted previously. Figure 4-27 presents the average number of items recovered by level for the excavations. A single peak, associated with Level 2, is present with a rapid falloff below Level 3 . The presence of a single peak suggests the possibility that the occupation reflects a limited time frame, a suggestion supported by the radiocarbon dates on the features. However, this scenario is not supported by the distribution of projectile points.
Figures 4-28 and 4-29 show some of the 24 points collected from the site. All 24 points could be minimally identified as representing either Late Prehistoric or Archaic forms. Figure 4-28 presents Late Prehistoric points, including six Sabinal points, an Edwards point (Figure 4-28, g) and two untypable arrow point fragments (Figure 4-28, h and i). In all, 12 arrow points or arrow point preforms were collected from this site. Figure 4-29 presents selected examples of Late Archaic forms collected at the site, including three specimens identified as Frio (Figure 4-29, a through c), four Ensor points (Figure 4-29, d through g) and two Figueroa types (Figure 4-29, h and i). The Late Prehistoric forms occurred in Level $1(\mathrm{n}=3)$, Level $2(\mathrm{n}=3)$, Level $3(\mathrm{n}=4)$, and Level 4 $(\mathrm{n}=1)$. The Archaic forms occurred on the surface $(\mathrm{n}=1)$ as well as in Levels $1(\mathrm{n}=2), 2(\mathrm{n}=2), 3(\mathrm{n}=4), 4(\mathrm{n}=1)$, and 5 $(n=2)$. The highest density of Archaic forms occurred in Level $3(n=4)$, the same level that contained most of the Late Prehistoric forms. The increase in debitage identified 


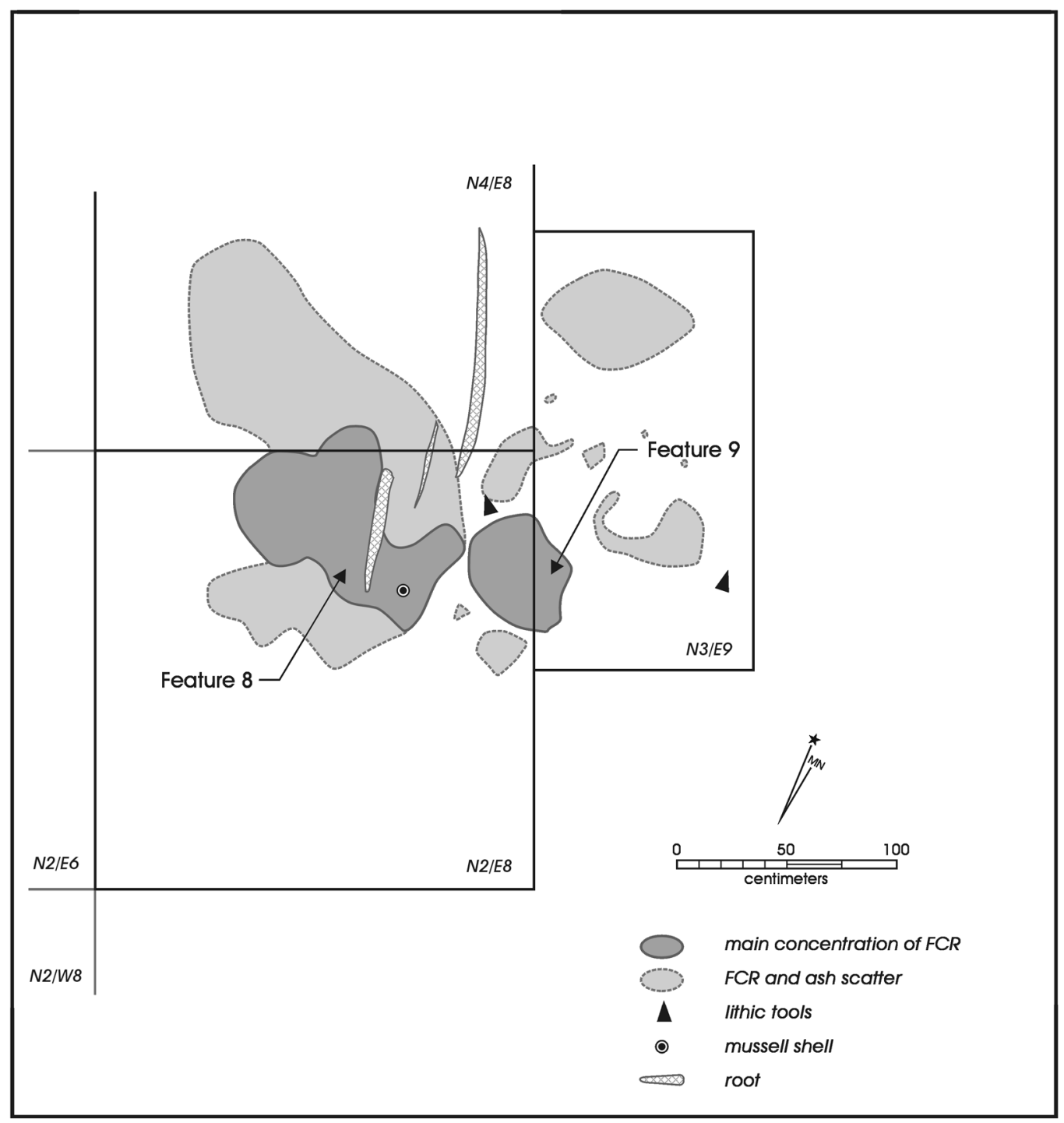

Figure 4-24. Features 8 and 9 at 41ZV226. 


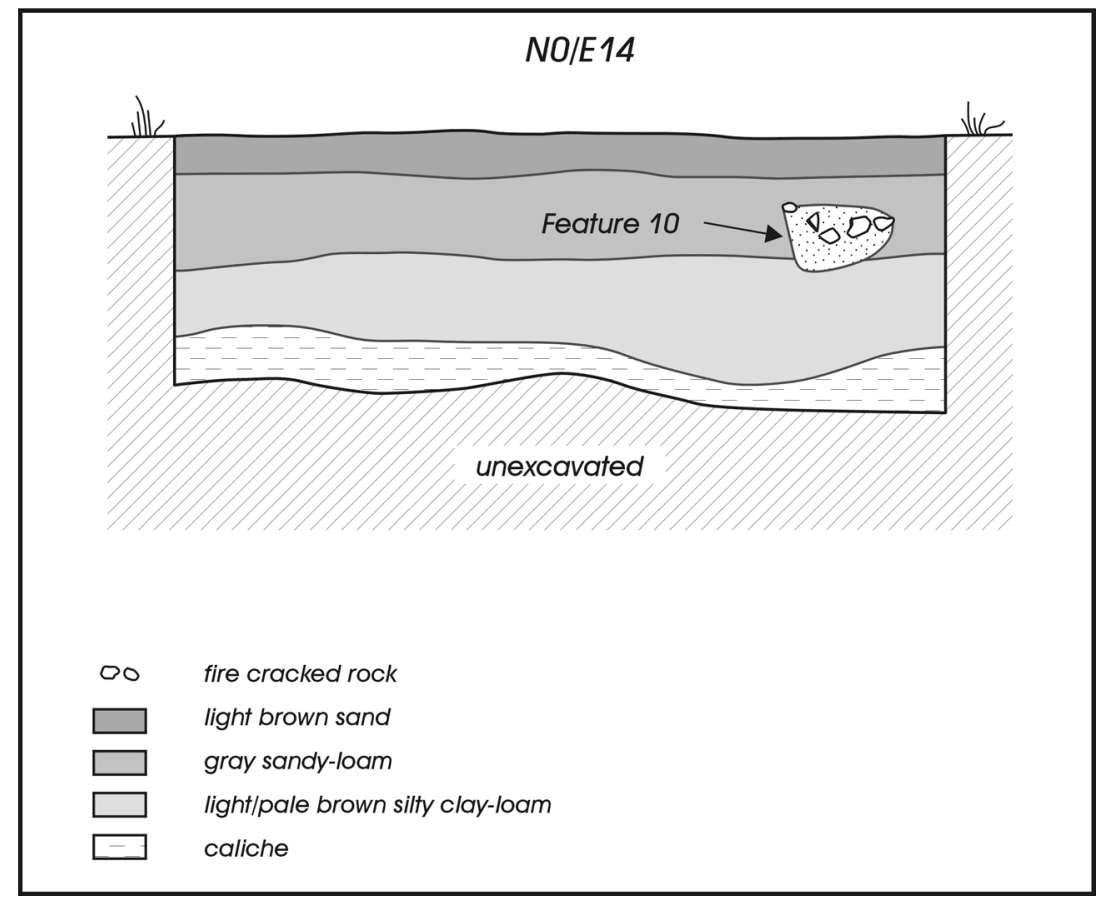

Figure 4-25. Feature 10 profile, Unit N0/E14, at 41ZV226.

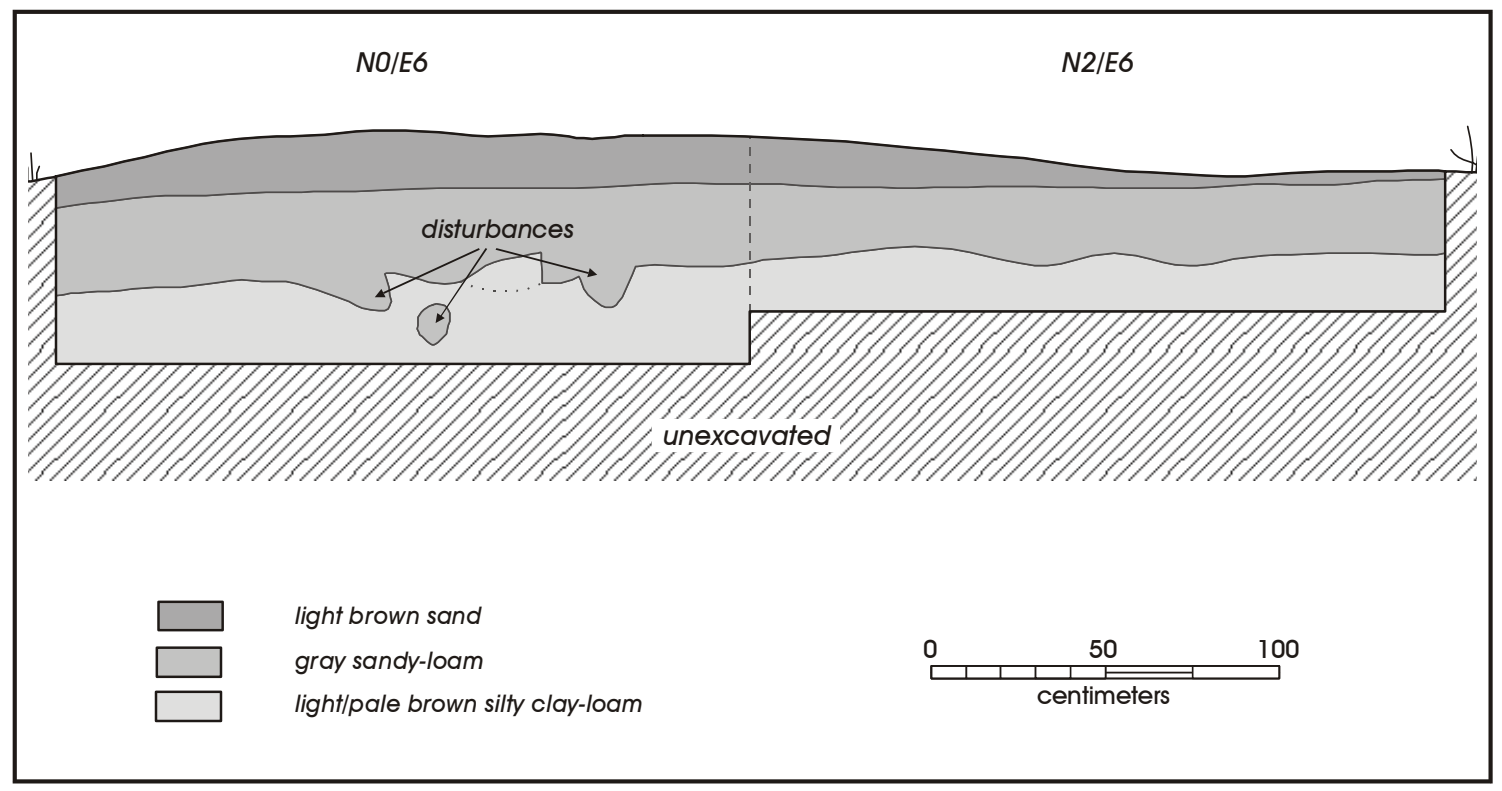

Figure 4-26. Profile of Units NO/E6 and N2/E6 at 41ZV226. 


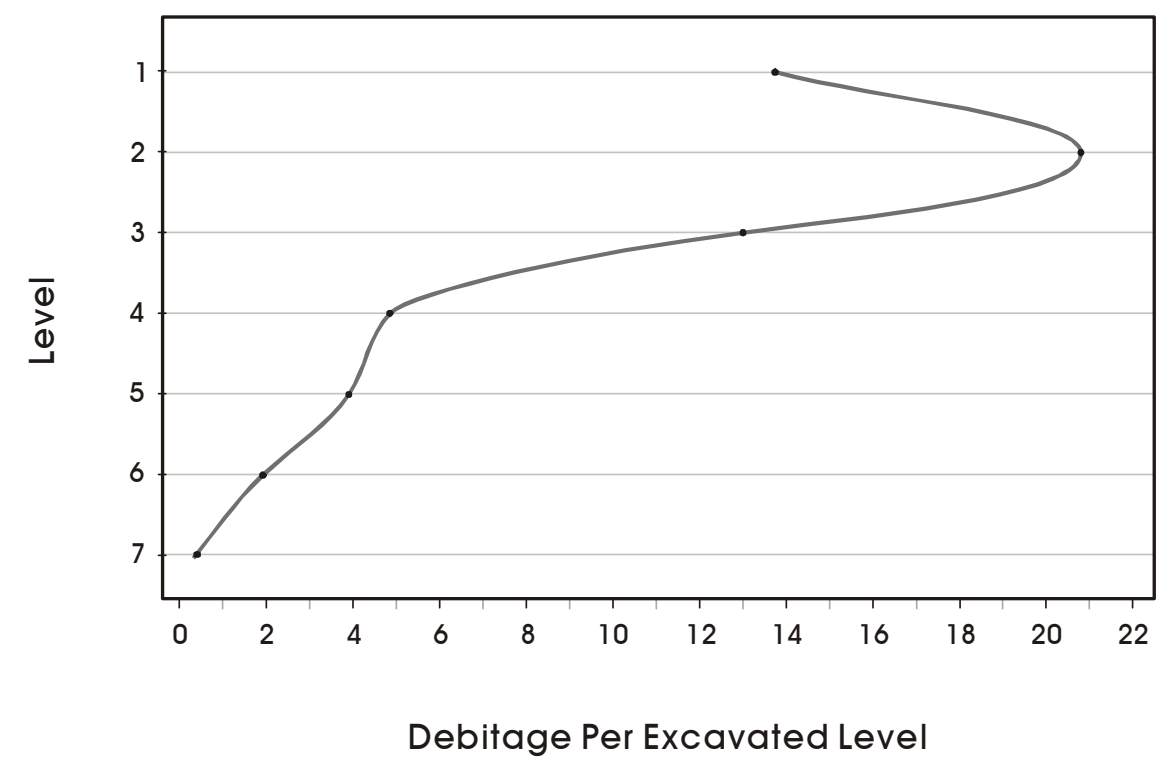

Figure 4-27. Average number of debitage recovered per excavated level at 41ZV226.

in Figure 4-27 is associated with both Late Prehistoric and Archaic forms. It appears, then, that no separation of the Late Prehistoric and Archaic assemblages is possible based on the point distributions at this site-wide scale.

Other tools recovered during the excavation included two unifaces, three edge modified flakes, and 23 bifaces. Figure 4-30 presents a selection of the bifaces from the site. In addition to the tools, debitage, and eight cores, there were 227 pieces of burned rock from this site. Burned rock was not systematically collected during the excavation and it is unclear what this assemblage represents.

Only three bones (4.09 g) were recovered from the excavations at 41ZV226. All came from Level 1 and probably represent modern rabbit remains. Thirteen proveniences contained small fragments of mussel shell and 645 snail shells were excavated from the site. Four pieces of burned clay were recovered. Historic materials from 41ZV226 include six pieces of glass, nine pieces of metal and a .22caliber casing, all from the upper two levels of the site.

\section{Summary}

Work conducted by TxDOT in 1982 at 41ZV226 suggests that the site has Late Archaic and Late Prehistoric materials and features. In addition, radiocarbon results suggest a possible Protohistoric component is present, though no clearly Protohistoric artifacts were recovered. A series of features, characterized by scattered burned rock and ash, were excavated. These seem to be the remains of hearths. Often, these features were found in close proximity to one another. Point forms recovered include both Late Archaic and Late Prehistoric types. Late Archaic points include several Frio, Ensor, and Figueroa forms. Late Prehistoric points are primarily classified as Sabinal, though a single Edwards was also uncovered. Ten radiocarbon dates from the site all fall within the Late Prehistoric $(n=6)$ or Protohistoric $(n=4)$ range. The vertical distribution of lithic debitage suggests the possibility that only a single peak, at Level 2, is present, but the point distribution does not allow any clear temporal assignment of that peak to a time period. Late Prehistoric points and Late Archaic points occur 


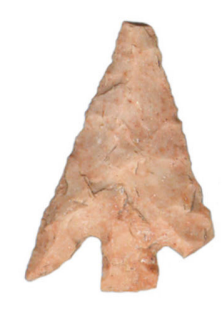

a

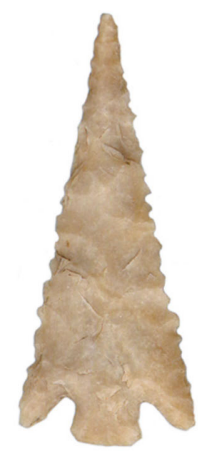

$f$

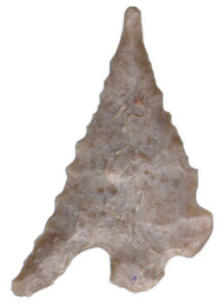

b

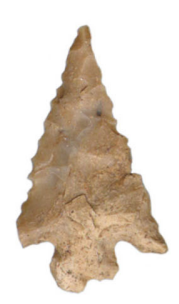

C

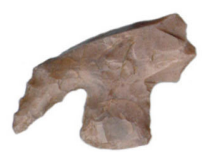

d

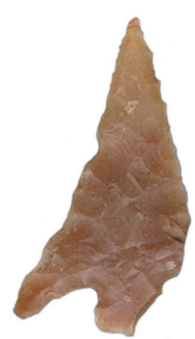

e

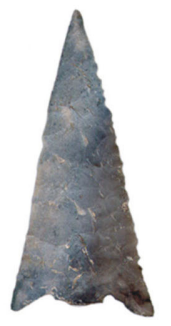

h

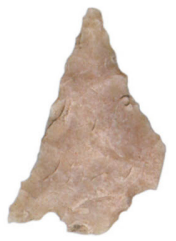

i

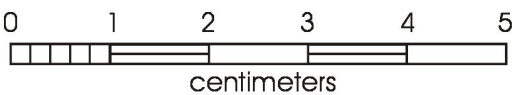

Figure 4-28. Selected arrow points recovered from 41ZV226. a-f) Sabinal; g) Edwards; h-i) untypable.

throughout the deposits, with Archaic forms recovered from the surface down to Level 5. Most Late Prehistoric forms were recovered in Level 3, but these points were present from Level 1 through Level 4. Limited information is provided by the animal bone collected. Note that SWCA has recently conducted additional work at this location (Houk et al. 2003). 


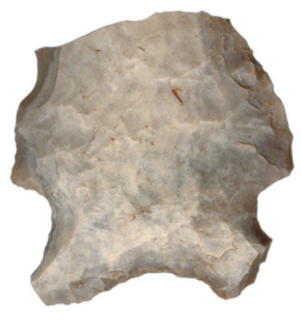

a

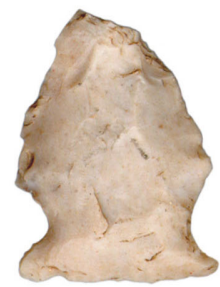

d

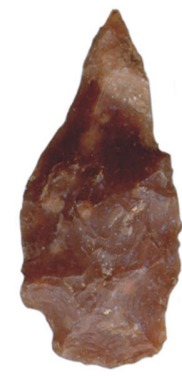

h

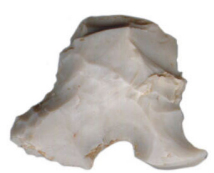

b

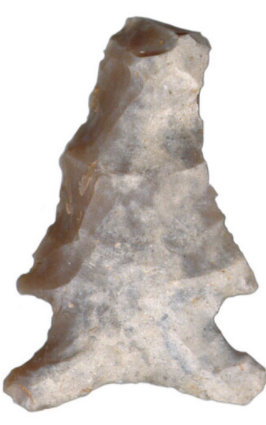

c

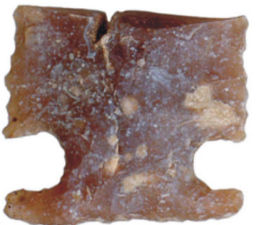

f

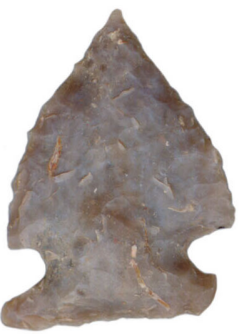

g

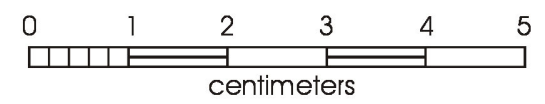

Figure 4-29. Selected dart points recovered from 41ZV226. a-c) Frio; d-g) Ensor; h-i) Figueroa. 


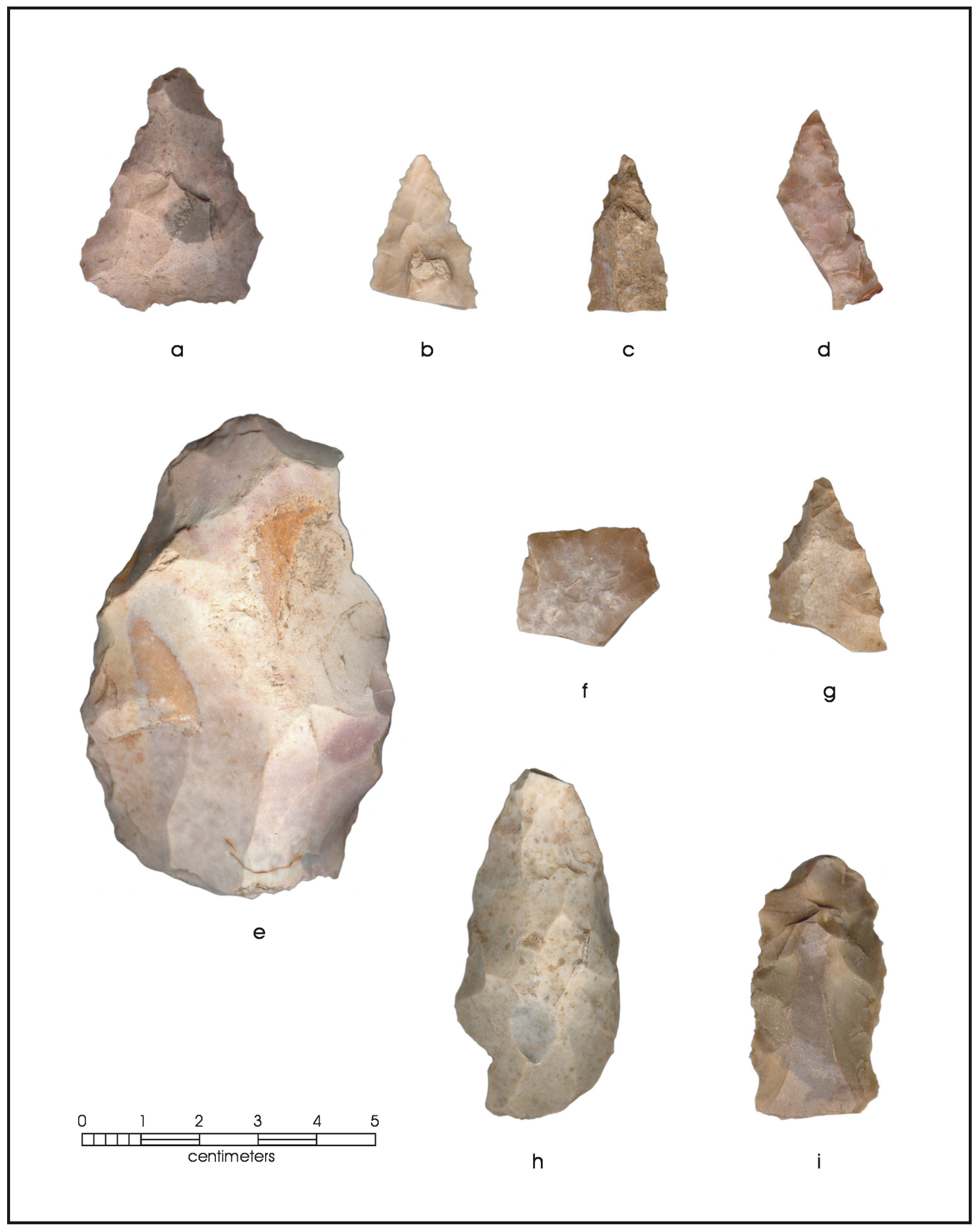

Figure 4-30. Bifaces recovered from 41ZV226. 


\section{ZV201}

This site, originally recorded by Crawford, is located about $300 \mathrm{~m}$ west of Conejo Creek at roughly $785 \mathrm{ft}(240 \mathrm{~m})$ AMSL on slightly sloping terrace deposits of that drainage (see Figure 1-4). No excavation was conducted at this site by TxDOT, but the locations of five hearths were mapped during 1982 by Henderson. Greaves et al. (n.d.) calls this location FS 8. The site rests on a Caid sandy clay loam on the low, west bank of Conejo Creek. Sites 41ZV452 and $41 \mathrm{ZV} 453$ are on the same landform toward the west. This site was initially recorded as a sparse surface scatter of lithics over a relatively large area. The size of 41ZV201 was estimated to be approximately $90 \times 90 \mathrm{~m}$. The area of
41ZV201 within the FM 481 right-of-way (Figure 4-31) is estimated to be $4,360 \mathrm{~m}^{2}$ (1.08 acres).

This site was revisited in June of 2002 by SWCA (O'Farrell and Miller 2002). The site was examined through surface inspection, one backhoe trench, and three shovel tests. That investigation identified moderate amounts of debitage and burned rock on the surface but concluded that the site has been severely impacted by road construction. Although less disturbed archeological deposits probably are present outside of the ROW, the SWCA investigation of the backhoe trench suggested that shallow deposits and surface disturbances indicate a low probability that significant information could be recovered at this site.

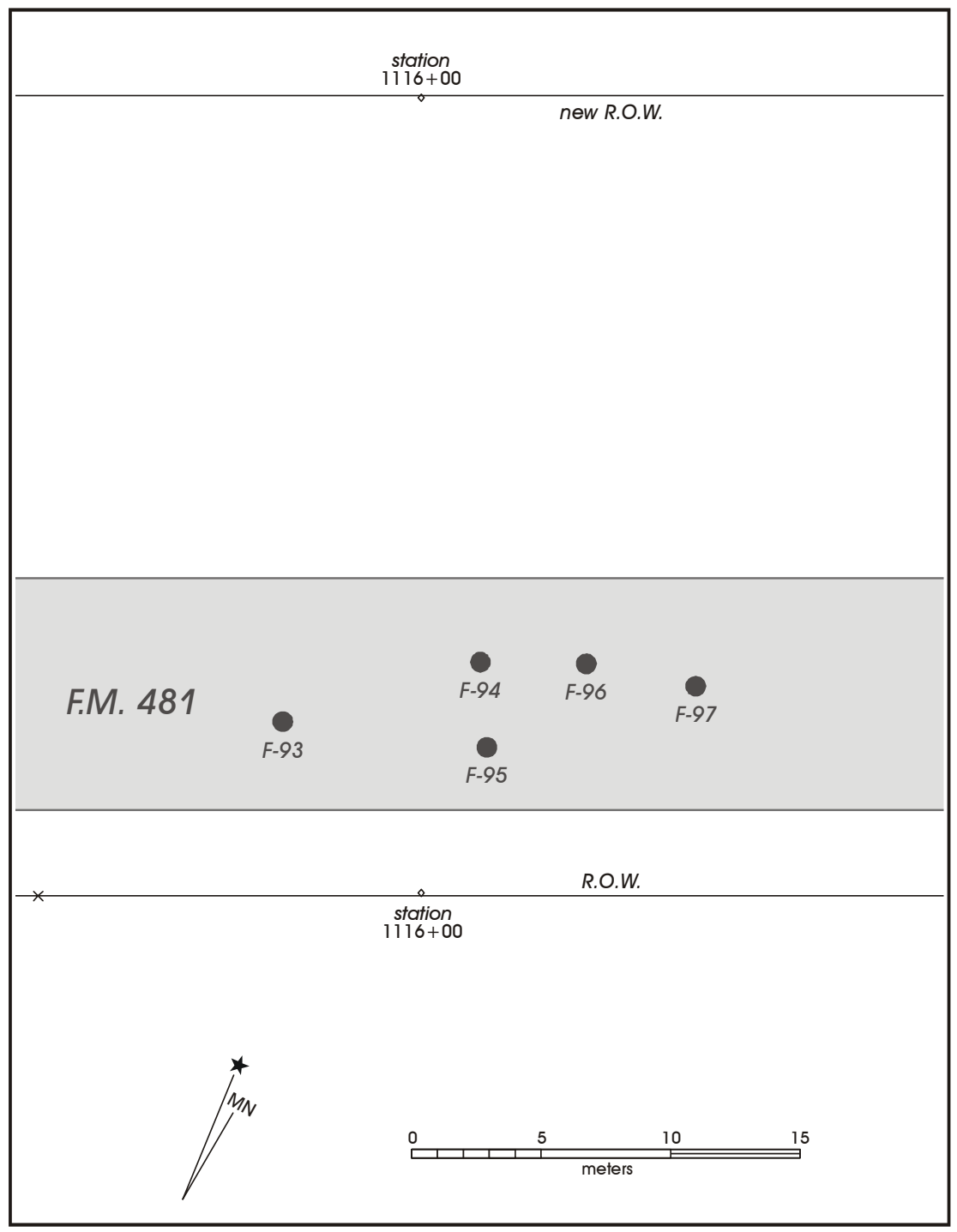

Figure 4-31. Site 41ZV201. 


\section{Fieldwork}

A 21-m section of FM 481 containing five exposed hearths (Features 93-97) was mapped by transit at the location of 41ZV201 (Figure 4-31). This was not recognized by the TxDOT field crew, but plotting of the road segment by CAR placed this portion of the road map within the plotted location of 41ZV201 (Greaves et al. n.d.). These features are briefly described as all being disturbed burned rock hearths approximately $49 \mathrm{~cm}$ to over $2 \mathrm{~m}$ in size. All contain rock and none were identified as having charcoal present. This small area of $164 \mathrm{~m}^{2}$ has a feature density of 3.04 hearths per $100 \mathrm{~m}^{2}$. No artifacts or samples were collected from this site. No photographs were taken of any of the features and no detailed feature maps were drawn.

\section{$41 Z V 452$}

Site $41 Z$ V452 was originally defined by Greaves et al. (n.d.) as FS 9. That designation was based on the description of 12 features along a $128-\mathrm{m}$ segment of roadway mapped by TxDOT in late 1982 (see Figures 1-4 and 4-32). The site, subsequently assigned trinomial $41 \mathrm{ZV} 452$ by SWCA (Houk et al. 2003), is located about $460 \mathrm{~m}$ from Conejo Creek (see Figure 1-4) on Pryor sandy clay loam at an elevation of about 790 feet (ca. $241 \mathrm{~m}$ ) AMSL.

The 12 features shown in the roadway on Figure 4-32 were primarily burned rock scatters. Three stains without associated rock were also recorded. The features range in size between $47 \mathrm{~cm}$ and $300 \mathrm{~cm}$ in diameter. One feature was associated with flakes. Another feature, consisting of a burned log, was considered to be recent. This area of 986 $\mathrm{m}^{2}$ has a feature density of 1.22 features per $100 \mathrm{~m}^{2}$. No samples or artifacts were collected from $41 \mathrm{ZV} 452$ by TxDOT in 1982, and there are no photographs of this location. SWCA has recently conducted limited work at this site (Houk et al. 2003).

\section{$41 Z V 453$}

Site 41ZV453 is on a low rise about $240 \mathrm{~m}$ west of an unnamed tributary that feeds into Conejo Creek (see Figure 1-4). The elevation of $41 \mathrm{ZV} 453$ is approximately $790 \mathrm{ft}$ (241 m) AMSL, and it is located on Pryor sandy clay loam. Site 41ZV453 was originally recorded by Henderson in 1982 and given the temporary number 41ZV203A. The site was identified by Greaves et al. (n.d.) as FS 10. The trinomial number (41ZV453) was assigned by Houk et al. (2003) during recent work at this location.

The site was originally recorded in late August of 1982 . Several burned rock features were observed in the FM 481 road at this location and investigations were undertaken just to the north of those features. Six units were excavated in this area during late August and early September of 1982 (Figure 4-33). Subsequently, TxDOT archeologists mapped 15 features along this highway segment, shown in Figure 4-33. The area of the roadway containing hearths represents $492.88 \mathrm{~m}^{2}$ and the density of features is 3.04 per $100 \mathrm{~m}^{2}$.

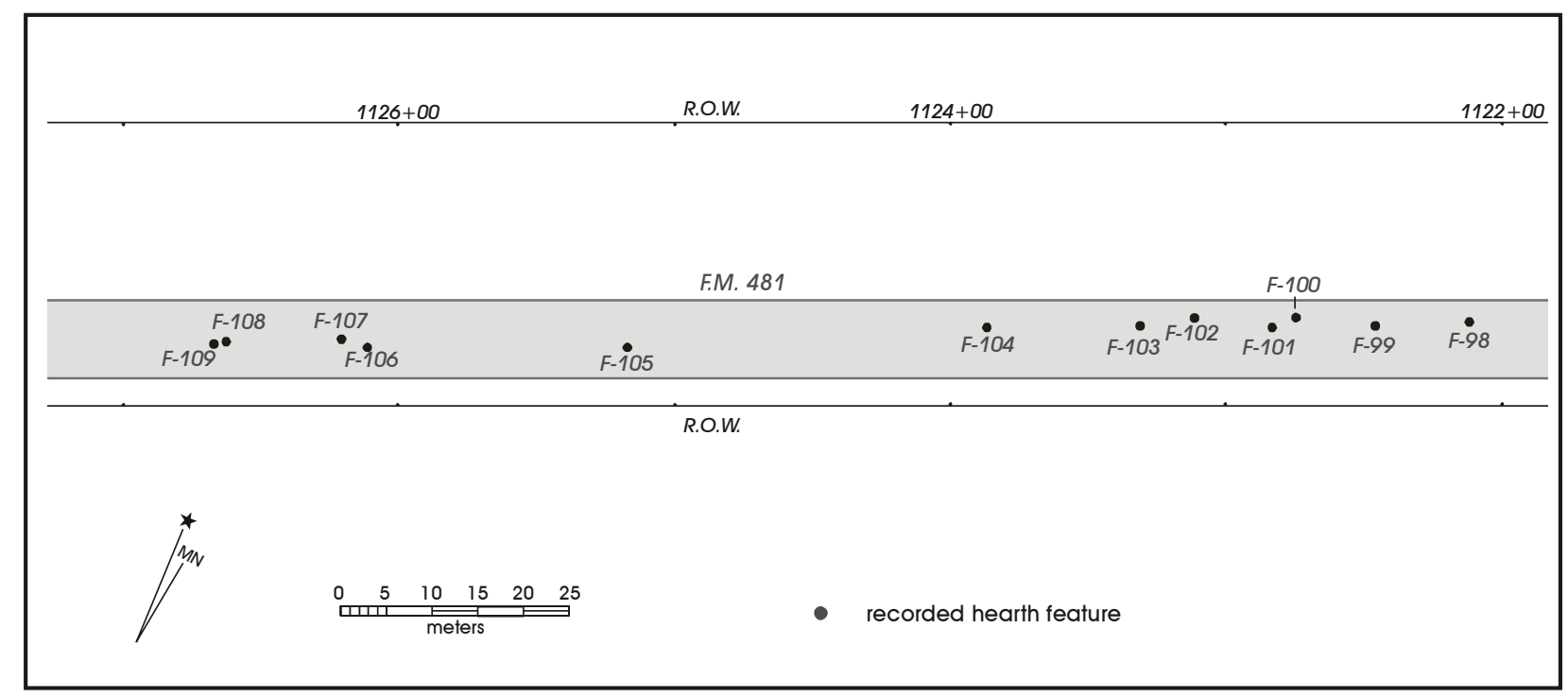

Figure 4-32. Site 41ZV452 feature distribution. 


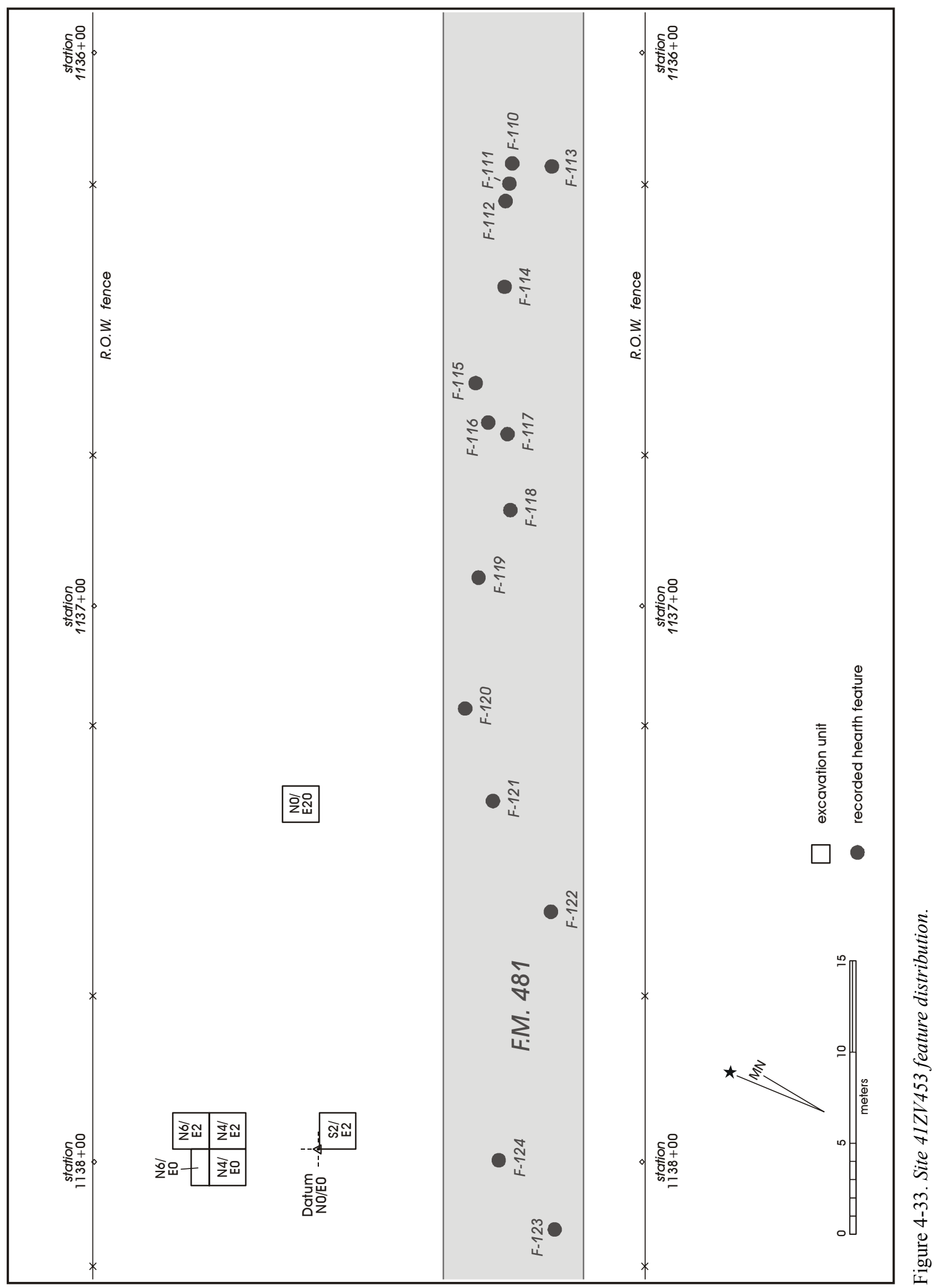


These features range from tight clusters of rock as small as $16 \mathrm{~cm}$, scattered areas of burned rock of approximately 3 $\mathrm{m}$, and stains with no associated rocks. At least one of the stains with associated charcoal was identified as a probable recent hearth.

\section{Fieldwork}

Testing of this site consisted of five $2-x-2-m$ units and a single 1-x-2-m unit (Figure 4-33). There is, however, considerable confusion regarding the associated artifacts, and the overall notes on the excavation are minimal (see Greaves et al. n.d.). Much of this confusion seems to be related to problems with daily notes and feature forms and drawings that occasionally refer to the E0 line as W0. It also appears that many of the artifacts were labeled W0 when notes were labeled E0. In spite of these confusions, it is clear that six units, arranged in the configuration shown in Figure 4-33, were excavated at this site. The few notes available for this site do not provide sufficient information to estimate the volume of screened material. Relying on the presence of artifacts as an indicator of the depth of excavation is also problematic, as no artifacts were recovered from the two 2-x-2-m units placed to the east (N0/E20) and south (S2/E2) of the main cluster of units (see Figure 4-33). While we do know, based on the artifact distribution and the notes, that several of the units were excavated to Level 5 , there are no artifacts recorded for N6/E2, and only a single artifact was recorded for Level 1 in any of the excavations. As some portion of the excavation units were removed without screening, it is probable that, like the work at some units on 41ZV226, the first level of screening was referred to as Level 2. However, there is no indication in the notes that this was, in fact, the case. It is also likely that the artifacts from N6/E2 are missing. Given these uncertainties, volume estimates were not attempted for this excavation.

In spite of these problems, it is clear that work at 41ZV453 did record four burned rock features. Eighty-five pieces of debitage and two cores, along with 13 pieces of burned rock, are present in the collections (Tables 4-7 and 4-8). No points are present in the collections, though two were noted as coming from Feature 2. One of these points was identified in the field as a Figueroa. The other point was not typed, but was a distal fragment of a dart point. One biface was noted from the surface though it is not in the collection. While no bone was recovered, fragments of mussel shell from two proveniences and 36 snail shells were recovered.

Table 4-7. Distribution of Artifact Classes by Unit, 41ZV453

\begin{tabular}{|l|c|c|c|c|c|c|c|c|}
\hline \multicolumn{1}{|c|}{ Prov/Unit } & $\begin{array}{c}\text { Burned } \\
\text { Rock }\end{array}$ & Charcoal & Core & Debitage & $\begin{array}{c}\text { Mussel } \\
\text { Shell* }\end{array}$ & Snail Shell & $\begin{array}{c}\text { Chipped Stone } \\
\text { Tools }\end{array}$ & $\begin{array}{c}\text { Grand } \\
\text { Total }\end{array}$ \\
\hline surface near S4E10 & & & & & & & 1 & 1 \\
\hline N04/E0 & 10 & 2 & 2 & 67 & 2 & 27 & 110 \\
\hline N04/E02 & 2 & 2 & & 13 & & 7 & & 24 \\
\hline N06/E02 & 1 & & & 5 & & 2 & & 8 \\
\hline Grand Total & 13 & 4 & 2 & 85 & 2 & 36 & 1 & 143 \\
\hline
\end{tabular}

*Numbers in Mussel Shell column indicate number of proveniences mussel shell was recovered from, not counts.

Table 4-8. Distribution of Artifact Classes by Level, 41ZV453

\begin{tabular}{|c|c|c|c|c|c|c|c|c|}
\hline Level & $\begin{array}{c}\text { Burned } \\
\text { Rock }\end{array}$ & Charcoal & Core & Debitage & $\begin{array}{c}\text { Mussel } \\
\text { Shell* }\end{array}$ & Snail Shell & $\begin{array}{c}\text { Chipped Stone } \\
\text { Tool }\end{array}$ & Grand Total \\
\hline surface & & & & & & & 1 & 1 \\
\hline 1 & 1 & & & & & & 4 & \\
\hline 2 & 6 & 1 & & 38 & & 4 & \\
\hline 3 & 1 & & & 22 & & 5 & & 28 \\
\hline 4 & 5 & 2 & 1 & 8 & 2 & 6 & 24 \\
\hline 5 & & 1 & 1 & 17 & & 21 & 40 & 1 \\
\hline Grand Total & 13 & 4 & 2 & 85 & 2 & 36 & 1 & 143 \\
\hline
\end{tabular}

*Numbers in Mussel Shell column indicate number of proveniences mussel shell was recovered from, not counts. 
Feature 1 was encountered in Level 2 of N4/E2 and the hearth was fully exposed in Level 3 . The feature was a tightly packed, slightly ovoid cluster of rocks that was about 50 $\mathrm{cm}$ by $50 \mathrm{~cm}$. The feature was thought to represent an intact hearth feature. Feature 2 was also identified in Level 2 of $\mathrm{N} 4 / \mathrm{E} 2$, though at a slightly higher elevation, and continued into N4/E0. Figure 4-34, a section of a Polaroid, shows the relationship of these two features, along with the location of Feature 3. The later feature was recognized in Level 5 of N4/E2. The rock in this feature extended northward and N6/E2 was excavated to expose more of this feature. No map of this feature was drawn and no additional information provided about it.

Feature 4 was partially exposed in the western wall of N6/E2 during removal of Features 1 and 2, at Level 5. A 1-x-2-m unit, N6/E0, was excavated west of N6/E2 to expose more of this feature. This was a small, circular feature interpreted as a hearth (Figure 4-35). Unfortunately, there is no reference point on this map so that the precise location of Feature 4 within N6/E2 and N6/E0 is not known. There also are no photographs of this feature. Figure 4-35 shows Feature 4 in relation to its possible location in N6/E2 and N6/E0 if reference marks on the TxDOT recording form were oriented to identify grid lines of these adjacent units.

Four charcoal samples were present in the collections from this excavation. CAR selected two individual pieces of charcoal, collected from a sample designated as being from Level 2 of N4/E0, and submitted these for radiocarbon dating. While there is no indication that this sample was directly associated with Feature 2, no other features are located in this unit at this level. Sample UGA \#12691 produced a corrected date of $1060 \pm 40 \mathrm{BP}$, while sample UGA \#12692 produced a date of $1010 \pm 40 \mathrm{BP}$. Calibrated dates, at one-sigma, are A.D. 900 to 1020 and A.D. 980 to 1160 (two-sigma, A.D. 890 to 1030 and A.D. 900 to 1160 ), respectively. Both of these dates, then, place the sample in the Late Prehistoric period. Note, however, that this date range is more recent than would be anticipated given the

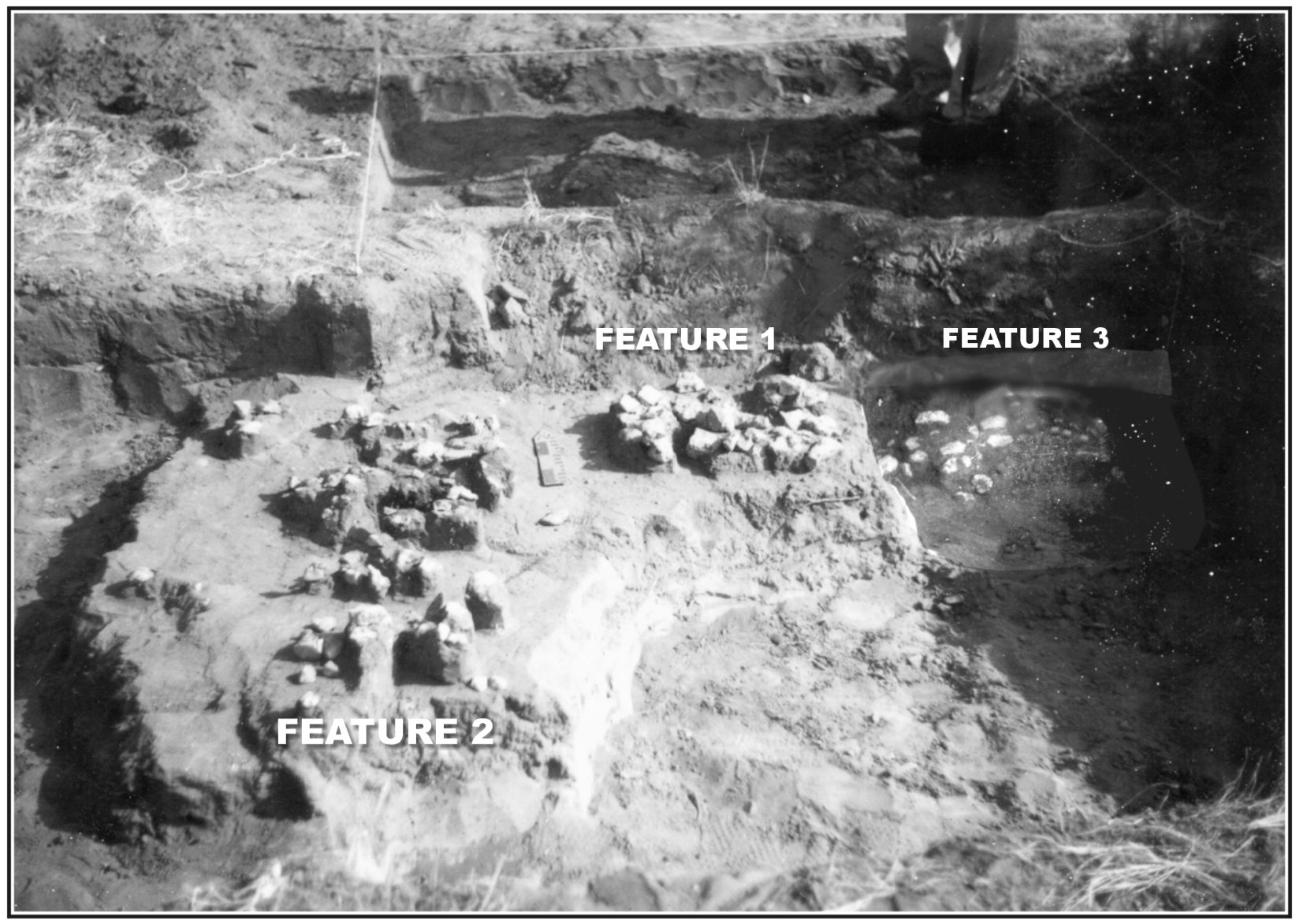

Figure 4-34. Features 1, 2, and 3 at 41ZV453. 


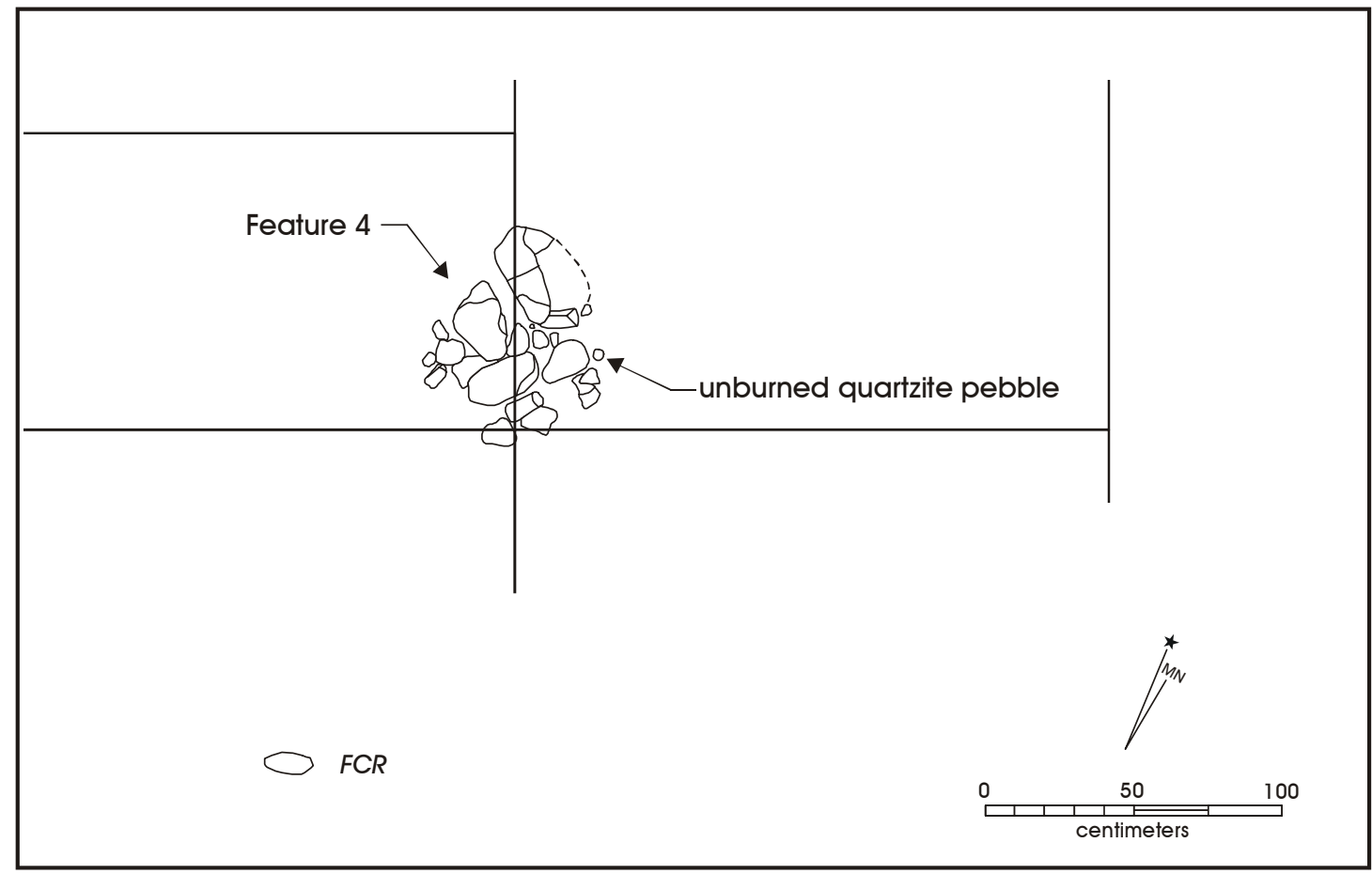

Figure 4-35. Feature 4 at 41ZV453.

presence of a Late Archaic Figueroa point associated with this feature.

\section{Summary}

Work conducted by TxDOT in 1982 at 41ZV453, while limited, suggests that the site may have both Late Archaic and Late Prehistoric occupations. Work included the excavation of four features, characterized by clusters of burned rock. These features appear to represent the remains of hearths. No projectile points were present in the collections, but field notes suggest that a Late Archaic point, as well as an additional Archaic dart point fragment, were recovered during fieldwork. Both of these items were associated with Feature 2, a hearth located in Level 2. The same level produced two radiocarbon dates that overlap and, while not securely associated with the feature, suggest a Late Prehistoric use sometime between A.D. 900 and A.D. 1160. Additional features were discovered below this level, and these may date to the Late Archaic. Information available from artifacts is minimal, and it is likely that more material besides the two points has been lost.

\section{ZV202}

Site 41ZV202 is located on the western bank of Muela Creek. The site is identified abutting the creek margin but is primarily situated on a low terrace at approximately $775 \mathrm{ft}$ $(235 \mathrm{~m}$ ) AMSL (see Figure 1-4). 41ZV202 rests on Tonio fine sandy loam soils. The total area of the site within the right-of-way is roughly $51,588 \mathrm{~m}^{2}$.

The site was originally recorded by Crawford in 1981, and Henderson conducted test excavations later that same year. The notes associated with this site suggest that abundant surface artifacts and an unspecified number of hearth features were present in the ranch entrance road on the northern side of FM 481 in 1981. Re-examination of this site has also been performed by SWCA in June of 2002 (O'Farrell and Miller 2002) and CAR conducted both testing and data recovery excavations on a section of the site in 2003. A report on that work was in preparation at the time of publication of this report. 


\section{Fieldwork}

The TxDOT testing of this site was done in late 1981, almost one year prior to archeological investigations at the other sites described in this report. Nine test units were excavated on 41ZV202 but no locational information exists for two of the units (Figure 4-36). The positions of the test units on this figure are relative and were created from a sketch map that lacks a scale. No grid system was used during the 1981 testing. The orientation of these test pits (TP) is also not precise (see discussion in Greaves et al. n.d.). As detailed in Greaves et al. (n.d.) the notes associated with the testing of this site are less than ideal. The dimensions of TP 2 and TP 7 were not recorded. No drawings or photographs exist for these two units, and while we have represented them as $1-x-1-m$ excavations on the map, their true size may be different. Most of the other test pits (TPs 3, 4, 5, and 6, see Figure 4-36) were associated with the excavation of coyote remains, which were ultimately determined to be modern. While artifacts were recovered from these excavations, they clearly lack integrity (see Greaves et al. n.d.). Finally, there are also several artifacts with labels referencing Test Pits 8 and 9 , though no information on these excavations could be found. Little use can be made of these data.

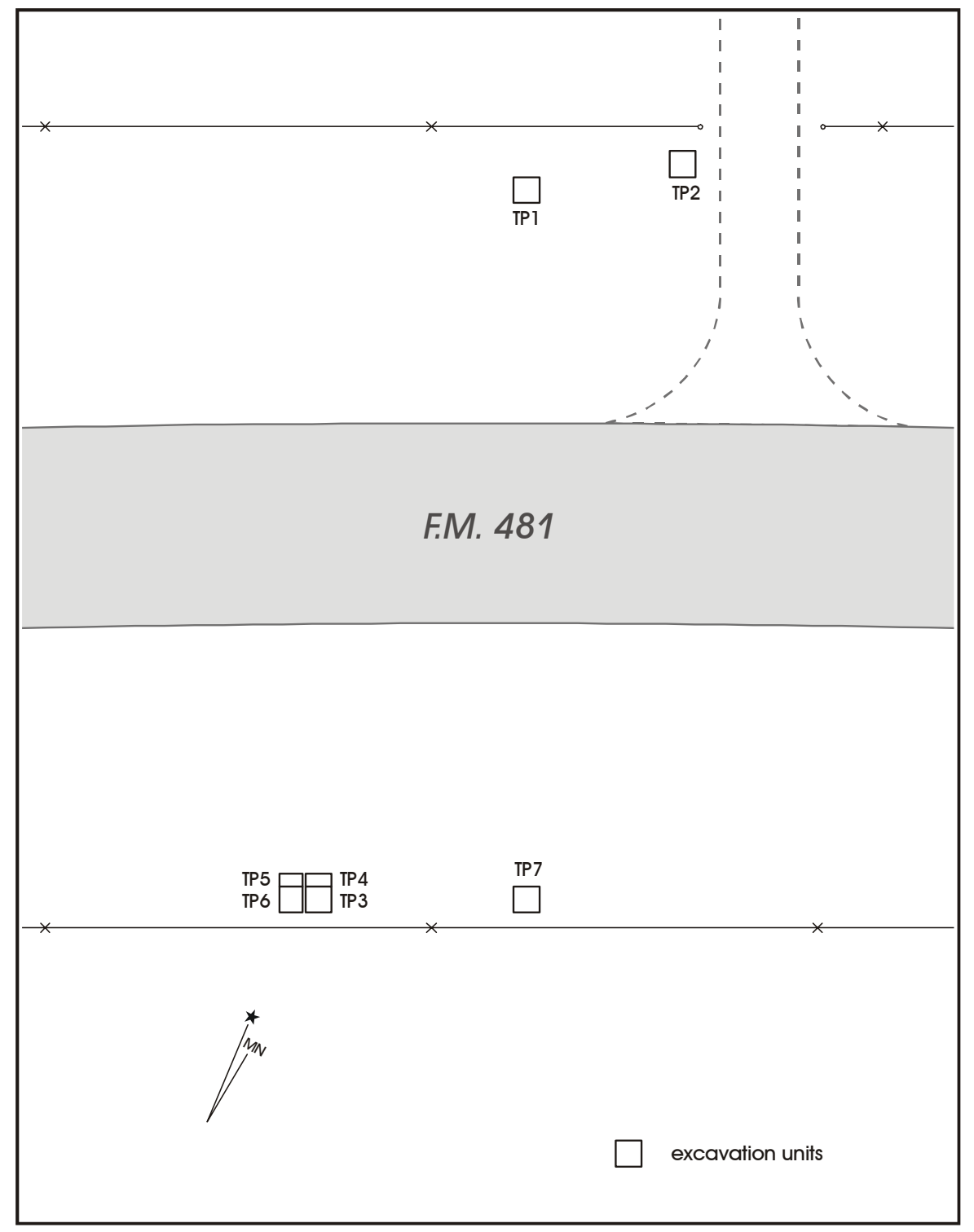

Figure 4-36. Excavation units at 41ZV202. 
Other than the burial pits associated with the coyote remains (Figure 4-37), no features were recorded during the excavation, although some form of additional disturbance is noted near the pits in Figure 4-37. Three hundred eleven pieces of debitage were collected from excavations in TPs 1, 2, and 7 (see Figure 4-36). These areas also produced one uniface, four bifaces, an edge modified flake, a scraper, and an Andice dart point stem fragment (TP 2, Level 1; Tables 4-9 and 4-10). The majority of these materials come from Levels $1-3$. Nine pieces of metal were collected from 41ZV202, one from TP 6 and eight from TP 8, suggesting that this unit was also associated with the coyote burials. One thousand, five hundred seventy-eight pieces of bone (814.96 g) were recovered from the excavation. A sizable proportion $(n=404$;
$26 \%$ ) of these came from TP 3 , TP 4, TP 5, and TP 6 . They represent the remains of at least five recently dispatched coyotes. An additional 1,169 specimens are from units TP 8 and TP 9, although their relationship to any other unit on the site is not known. The remaining five specimens came form TP 2. Among the non-coyote bones, one rabbit (Sylvilagus sp.) bone, one rodent bone, and six bird bones were identified. Only three bones appeared to be from a large mammal, and 154 other mammal bones are canid-sized. Unidentified mammal remains account for 952 elements. Snail $(n=34)$ and mussel shells also were also recovered, with five proveniences yielding small fragments of mussel shell. Finally, TP 3, Level 3 , produced the only other untyped dart point fragment recovered from a buried, although, disturbed context.
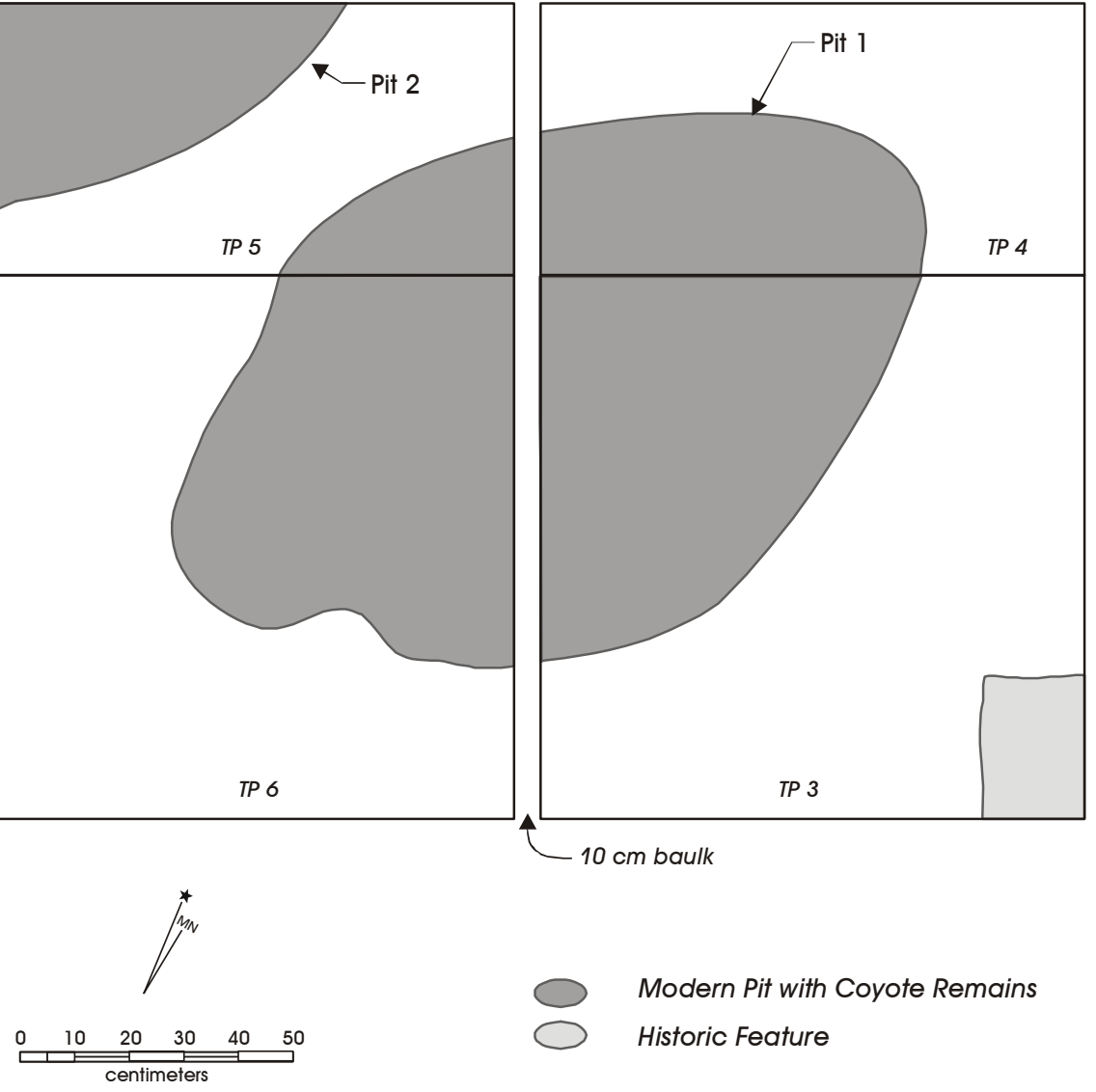

Modern Pit with Coyote Remains

Historic Feature

Figure 4-37. Test Pits 3 through 6, and coyote burial pits 1 and 2, at 41ZV202. 
Table 4-9. Distribution of Artifact Classes by Unit, 41ZV202

\begin{tabular}{|c|c|c|c|c|c|c|c|c|c|c|c|c|c|}
\hline Prov/Unit & Bone & \begin{tabular}{|c|} 
Burned \\
Rock
\end{tabular} & Charcoal & Core & Debitage & \begin{tabular}{|c|} 
Ground \\
Stone
\end{tabular} & Historic & \begin{tabular}{|l} 
Mussel \\
Shell*
\end{tabular} & \begin{tabular}{|c|} 
Natural \\
Clast
\end{tabular} & $\begin{array}{c}\text { Projectile } \\
\text { Point }\end{array}$ & \begin{tabular}{|l|} 
Snail \\
Shell
\end{tabular} & \begin{tabular}{|c|} 
Chipped \\
Stone Tool
\end{tabular} & $\begin{array}{c}\text { Grand } \\
\text { Total }\end{array}$ \\
\hline surface & & & & 3 & 76 & 2 & & & & 4 & & 24 & 109 \\
\hline TP1 & & 1 & & & 125 & & & 1 & & & 9 & 1 & 137 \\
\hline TP2 & 5 & & 2 & & 102 & & & 1 & 1 & 1 & 25 & 4 & 141 \\
\hline TP3 & 225 & & 1 & & 8 & & & 2 & & 1 & & & 237 \\
\hline TP4 & 98 & & & & 4 & & & & & & & & 102 \\
\hline TP5 & 3 & & & & 3 & & & & & & & & 6 \\
\hline TP6 & 78 & & & & 5 & & 1 & & & & & & 84 \\
\hline TP7 & & & 1 & & 84 & & & 1 & 1 & & & 2 & 89 \\
\hline TP8 & 371 & & & & & & 8 & & & & & & 379 \\
\hline TP9 & 798 & & & & & & & & & & & & 798 \\
\hline Grand Total & 1578 & 1 & 4 & 3 & 407 & 2 & 9 & 5 & 2 & 6 & 34 & 31 & 2082 \\
\hline
\end{tabular}

*Numbers in Mussel Shell column indicate number of proveniences mussel shell was recovered from, not counts.

Table 4-10. Distribution of Artifact Classes by Level, 41ZV202

\begin{tabular}{|c|c|c|c|c|c|c|c|c|c|c|c|c|c|}
\hline Level & Bone & \begin{tabular}{|c}
$\begin{array}{c}\text { Burned } \\
\text { Rock }\end{array}$ \\
\end{tabular} & Charcoal & Core & Debitage & \begin{tabular}{|c|} 
Ground \\
Stone
\end{tabular} & Historic & \begin{tabular}{|c|} 
Mussel \\
Shell*
\end{tabular} & \begin{tabular}{|c|} 
Natural \\
Clast
\end{tabular} & $\begin{array}{c}\text { Projectile } \\
\text { Point }\end{array}$ & \begin{tabular}{|l|} 
Snail \\
Shell \\
\end{tabular} & \begin{tabular}{|c|} 
Chipped \\
Stone Tool \\
\end{tabular} & $\begin{array}{c}\text { Grand } \\
\text { Total }\end{array}$ \\
\hline surface & & & & 3 & 76 & 2 & & & & 4 & & 24 & 109 \\
\hline 1 & 400 & & 1 & & 102 & & 1 & & 1 & 1 & 1 & 2 & 509 \\
\hline 2 & 298 & & & & 111 & & 8 & 2 & & 1 & 21 & 2 & 443 \\
\hline 3 & 613 & 1 & 2 & & 71 & & & 2 & & & 6 & 2 & 697 \\
\hline 4 & 58 & & 1 & & 38 & & & 1 & 1 & & 3 & 1 & 103 \\
\hline 5 & & & & & 8 & & & & & & 1 & & 9 \\
\hline 6 & 209 & & & & 1 & & & & & & 2 & & 212 \\
\hline Grand Total & 1578 & 1 & 4 & 3 & 407 & 2 & 9 & 5 & 2 & 6 & 34 & 31 & 2082 \\
\hline
\end{tabular}

*Numbers in Mussel Shell column indicate number of proveniences mussel shell was recovered from, not counts.

\section{Summary}

In addition to the above excavation, an unsystematic surface collection of 133 items was made at the site. The surface collection included 76 pieces of debitage, three cores, four projectile points (two Frio, one Ensor, one Marcos), and 24 chipped and two ground stone tools. This material lacks provenience. Figure 4-38 presents five of the six points recovered from the site. All are dart points. Shown are a Marcos (Figure 4-38, a), an Ensor (Figure 438, b), a Frio (Figure 4-38, c) and two untyped Late Archaic points (Figure 4-38, d and e). These were all collected from the surface. As noted previously, a variety of other tools were also collected at this site. These include a relatively large number of unifaces $(n=13)$, nine bifaces, and two edge modified flakes. Several of these are shown in Figures 4-39 and 4-40, as are the two pieces of ground stone (Figure 4-40, a and b).
The testing of 41ZV202 in 1981 by TxDOT archeologists was primarily focused on exploring a series of pits that contained the remains of several coyotes. These burials were ultimately determined to be modern. While at least three units were excavated away from this location, the documentation of that work is minimal. A relatively large collection of tools from the site exists. Unfortunately, many of these are from surface context and lack provenience. Nevertheless, the collection does include a variety of unifaces that were probably used as scrapers, as well as a metate fragment and a single mano. Interestingly, all of the points collected from 41ZV202 by TxDOT are Archaic in age, with Late Archaic forms including Frio, Ensor, and Marcos. While this suggests a single component, Late Archaic time frame for the site, CAR's recent work at the site has documented a Late Prehistoric occupation in the upper deposits. 


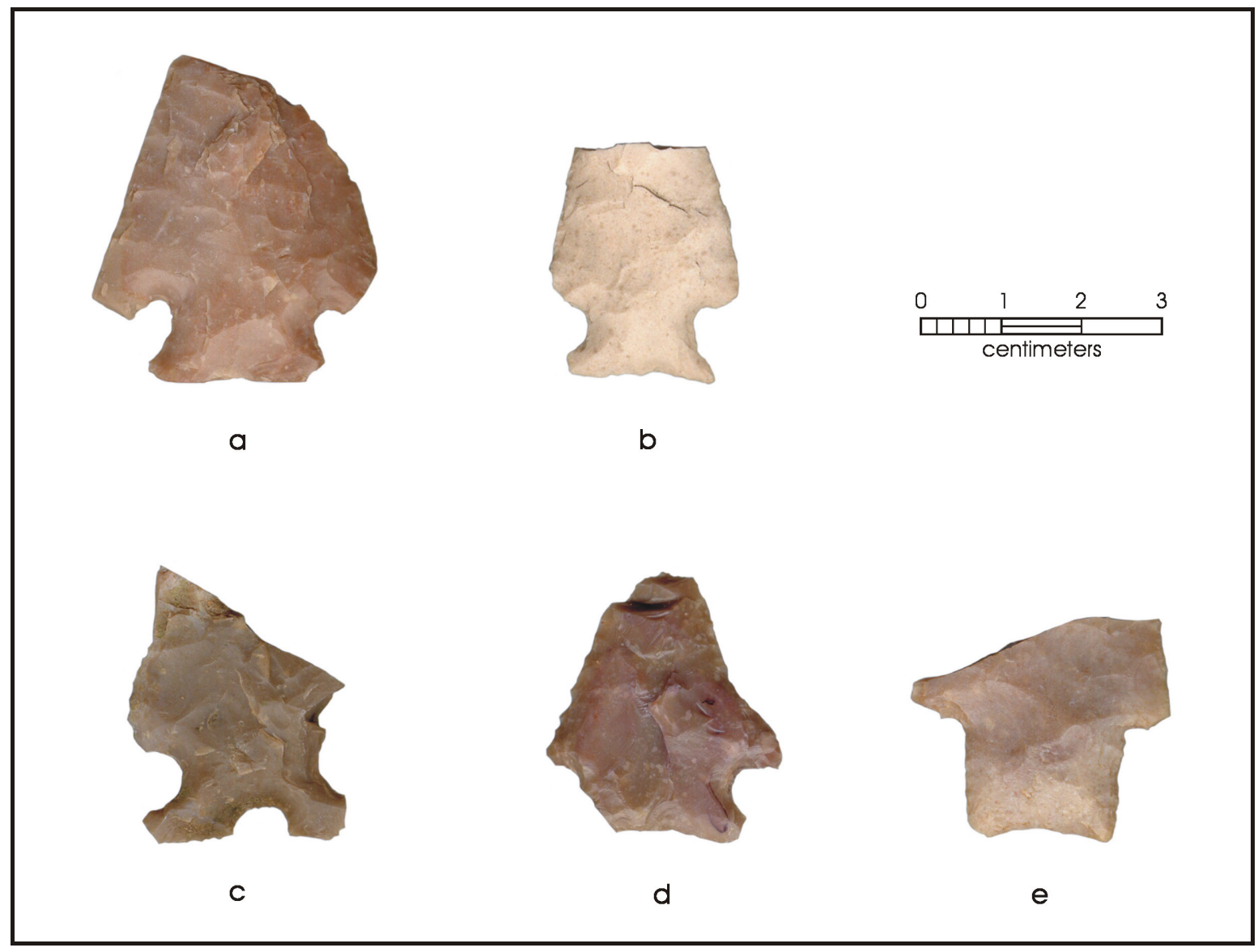

Figure 4-38. Selected projectile points from 41ZV202. a) Marcos; b) Ensor; c) Frio; d-e) untyped Late Archaic.

\section{Chapter Summary}

This chapter has provided descriptive data for what have now been determined to be nine archeological sites along FM 481 in Zavala County. These sites were tested or mapped by TxDOT in 1981 and 1982. The work was conducted under what were essentially salvage conditions and documentation of what was done is, unfortunately, less than ideal. Nevertheless, the project did provide some descriptive information relevant to understanding aspects of the region. Late Archaic and Late Prehistoric remains are present throughout the FM 481 right-of-way. The sites seem to be dominated by small, dispersed burned rock features associated with scattered artifacts. On most of the sites where testing was conducted, the recovered artifacts suggest that multiple components are present. This impression was confirmed in several cases by recently acquired radiocarbon dates on several features from selected sites. In at least one case, those dates suggest the possibility of Protohistoric use, though no Protohistoric artifacts were recovered. The multicomponent nature of the sites, combined with the limited documentation present for many of the excavations, limits the research potential of the data collected. 


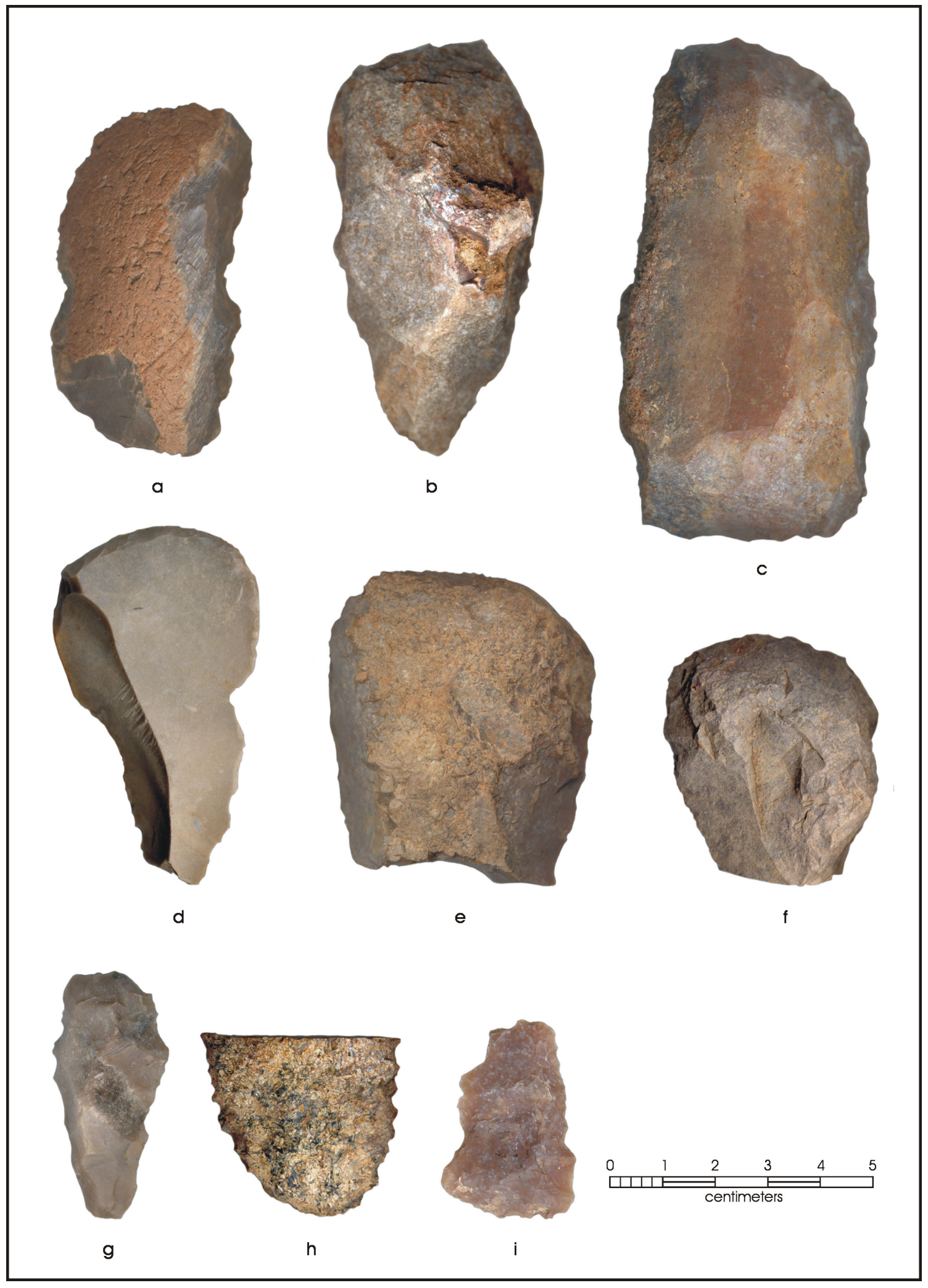

Figure 4-39. Selected unifaces and bifaces from 41ZV202. a-f) scrapers; g-i) bifaces. 


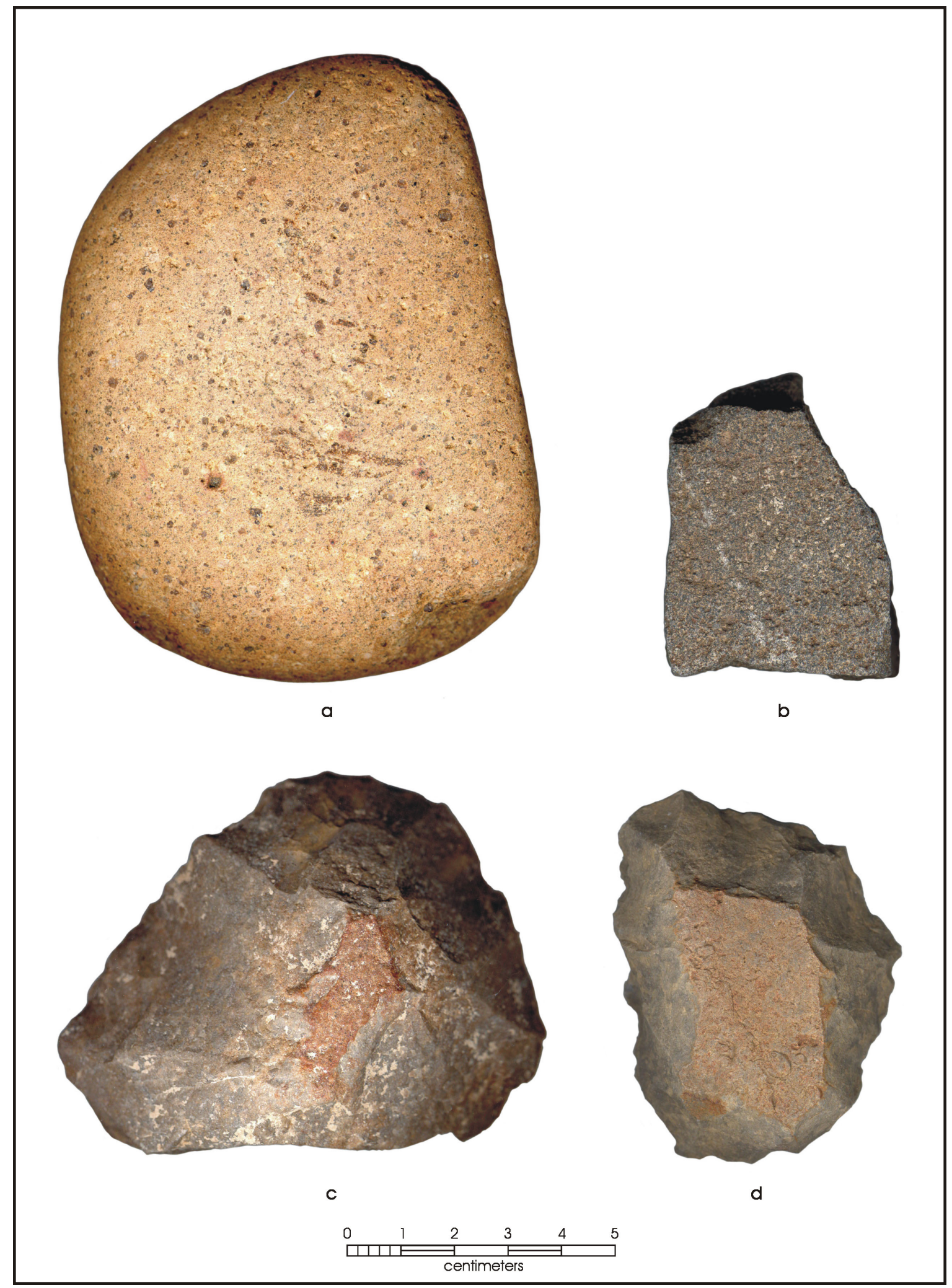

Figure 4-40. Other stone tools recovered from 41ZV202. a-b) ground stone; c-d) bifaces. 


\title{
Chapter 5: Research Directions and Results
}

\author{
Raymond P. Mauldin, J. Philip Dering, and Steve A. Tomka
}

The previous chapter described the work conducted by TxDOT staff in 1981 and 1982 along FM 481 in northwest Zavala County. Based on our investigations associated with the previous collections assessment document (Greaves et al. n.d.) and in combination with the results of subsequent work by SWCA along the same project area, we have concluded that the TxDOT work focused on several areas that have since been defined as nine archeological sites. From west to east along the FM 481 right-of-way, these sites are: 41ZV197, 41ZV198, 41ZV450, 41ZV451, 41ZV226, 41ZV201, 41ZV452, 41ZV453, and 41ZV202.

The previous chapter reviewed the investigations conducted at each site, the methods employed in data collection, and the types and quantities of data that were obtained from each site. The first part of the current chapter summarizes the principal research themes originally proposed by Greaves et al. (n.d.) and briefly reviews why our research focused on only four of the sites. The second part of the chapter presents the results of the analyses associated with the proposed research themes. The final section of the chapter summarizes the overall results of the analyses performed.

\section{Research Directions and Analytical Methods}

As reference to the previous chapter will demonstrate, many of the sites along FM 481 are characterized by low-density scatters of lithic debris, numerous burned rock features, and scattered burned rock. The sites tend to be multicomponent, as in the case of five of the nine sites discussed in Chapter 4 , or lack any temporal diagnostics (four of the nine sites). Reference to our short discussion in Chapter 3 will confirm that such sites are probably a common component of the archeological record in South Texas. Such occupations most likely represent repeated, short-term use of an area over a significant time period. The fact that testing at these sites occurred in a narrow linear corridor cross-cutting the sites is inherent in highway construction-related archeological efforts. While the materials collected from this arbitrary corridor may represent a biased sample of a site's content and significance, it does not mean that other portions of the site found outside of the right-of-way could not potentially retain integrity and may be eligible for NRHP listing or for designation as a SAL.
Under normal survey, testing and data recovery efforts, information recovered from multiple sites such as these would potentially be of significant research value. For instance, at the onset of the assessment of the artifact collections and associated documentation received from TxDOT, and upon our initial review of the artifacts and notes, we felt that the possibility existed to pursue at least three broad research themes: 1) the analysis of site-use history and possibly structures on sites with multiple burned rock hearths; 2) the analysis of changes in hearth-associated lithic assemblages through time; and 3) paleoenvironmental analysis oriented to the reconstruction of moisture regimes during specific times. As our initial review and assessment of the collections and documentation continued, it became evident that site-level research topics such as the study of site structure could not be pursued because we lacked detailed site maps, and beyond the mention of their existence, the rescue conditions simply did not allow time to investigate many of the features noted on sites.

As a result, based on a broad initial review of the artifact collections and records, we concluded that given the available data types and the absence of critical information related to feature distributions, the more appropriate units of analysis would be the features within sites rather than the sites themselves. As analytical units, the features provide three significant advantages. First, they contain datable materials that can be used to anchor them in time. Second, charred mesquite recovered from features may be used to reconstruct prehistoric moisture regimes. And finally, features retain nearby artifact distributions that, because of their proximity, have a greater likelihood of relating behaviorally and temporally to the features than artifacts recovered from other parts of the site. Therefore, we dismissed the notion that we would be able to address issues of site structure and activity area organization and began focusing on two principal research topics dependent on feature-associated data types: 1) changes in lithic technology as potentially visible in feature-proximate lithic assemblages; and 2) the reconstruction of prehistoric moisture regimes as documented in feature-associated and radiocarbon dated mesquite xylem.

Once our more intensive review of the collections and associated documentation began, it became evident that the work conducted at some of the sites (i.e., 41ZV201, 
41ZV450, and 41ZV452) was very limited and produced either only non-temporally diagnostic materials and/or only feature descriptions. In addition, while four units were excavated on site 41ZV451, no artifacts were recovered, and although a feature was tested on site 41ZV197, no radiocarbon samples were recovered. Finally, even for sites that contained multiple burned rock features that potentially could have provided information on site use and organization of activity areas, the low level of documentation that could be secured under archeological rescue conditions, as well as the limited amount of work conducted at the sites, resulted in very limited data. Therefore, in light of the absence of any data types that would have allowed us to address the two research topics we intended to focus on, we proposed that sites 41ZV197, 41ZV201, 41ZV450, 41ZV451, and $41 \mathrm{ZV} 452 \mathrm{had}$ no potential to contribute meaningful data and information. TXDOT and Texas Historical Commission review staff agreed with these recommendations upon reviewing the quality of the available data and the proposed research topics.

The remaining four sites, 41ZV198, 41ZV202, 41ZV226, and 41ZV453, have the following characteristics in common: 1) they have been subject to subsurface investigations; 2) they contain at least one feature that has been excavated; 3 ) with one exception (41ZV202), at least one of the excavated features from the site has been mapped; 4) at least one of the features investigated also produced a radiocarbon sample; 5) the investigations recovered a chipped lithic assemblage, including temporally diagnostic projectile points; and 6) the archeological materials (features and artifacts) identified on the sites come from a combination of surface and buried contexts. Based on these important commonalities, it was felt that these four sites could provide the opportunity to pursue the two principal research topics using features and data obtained from features as the principal analytical units.

Below we review the details of the two research themes and the proposed analytical methods. This section is followed by the discussion of the analysis results including the failure to identify lithic assemblages that could be confidently assigned to a narrow span of feature use, and the encouraging results of mesquite xylem analysis and the reconstructed oscillations in moisture regimes.

\section{Changes in Lithic Technology}

We have mentioned previously that the wholesale analysis of entire lithic assemblages recovered from the four sites is not desirable because of the multicomponent nature of the sites and the high likelihood that overall the materials are a product of numerous reoccupation episodes. Greaves et al. (n.d.) proposed that one way to address this problem was to narrow the analytical approach to sub-samples of lithic artifacts that came from around features that could be dated. Dating of the feature would anchor it in time, while limiting the samples to artifacts from near the feature would increase the likelihood that the majority of the specimens in the subsample may be behaviorally related to the dated feature. We assumed that this approach would allow us to study changes in lithic technology within dated samples that are associated with features, therefore, providing a look at the types of stone tool manufacture and repair activities (i.e., reduction strategies) that were carried out adjacent to hearths and how these activities and those associated with them (i.e., raw material procurement) may have changed through time.

Before operationalizing this research strategy, we needed to address two complicating factors. First, just because a flake or a biface was recovered $1.5 \mathrm{~m}$ away from the edge of a hearth, what evidence can we muster to support the assumption that this artifact is behaviorally related to the hearth while an artifact that is $5 \mathrm{~m}$ away is not? Second, even if we assume that proximity can be used as a proxy for association, how can we establish that two or more hearth-proximate items all relate to the same or temporally closely spaced hearthassociated activities when we know that the four sites all appeared to be multicomponent based on temporal diagnostic artifacts? For instance, and as summarized in the previous chapter, both arrow points and dart points were recovered from 41ZV226, and Middle and Late Archaic points were found on 41ZV202. Despite the fact that only two Frio points were recovered from 41ZV198, and 41ZV453 only produced a Figueroa point, we cannot assume that these sites represent single-component occupations.

Ethnoarcheological research (Binford 1978; O’Connell 1987) and in some instances even ethnohistoric descriptions related to hunter-gatherer site structure can provide general guidelines to model activity patterns surrounding hearths. 
For instance, Binford's drop-zone (0.5-1.2-meter arch) and toss-zone (1.5-2.5-meter arch) model can serve as a source of general expectations and has been applied with some success to the interpretation of hearth-centered lithic assemblages (Stevenson 1991).

Even if this drop/toss zone model provides a methodological solution to the first of the complicating factors, site and hearth reuse as well as changes in conditions adjacent to the hearth could blur the identification of such patterning. Even more importantly, how do we address the second complicating factor, establishing rough contemporaneity of hearth-proximate artifacts?

In the research design portion of the previous assessment document (Greaves et al. n.d.), we proposed to solve the issue of contemporaneity through the dating of multiple radiocarbon samples from the same feature, or of multiple individual pieces of charcoal from a single sample from the same feature. Here we argue that features with radiocarbon dates that range over several hundred years or more could be assumed to represent several reuse episodes, or represent locations that potentially had non-feature related charcoal introduced by other means. In either case, when multiple dates do not cluster, it becomes very difficult to support, with any degree of confidence, that the materials recovered from around the hearth are actually temporally and/or behaviorally associated. On the other hand, we assume that features with radiocarbon dates that cluster probably represent a single use or multiple uses over a short period of time. Also, in these instances, we assume that there is a higher probability that the artifacts found in close proximity (i.e., associated units and levels) to the feature are contemporary with that feature. In these cases, the dated feature and associated artifacts form a related set of materials.

With these methodological complications addressed, in the previous assessment document we proposed a series of specific lithic analysis attributes that would allow us to quantify and gauge changes in lithic reduction strategies and raw material procurement within sub-samples derived from feature-proximate recovery contexts. Although we did not specify the distances that constituted feature-proximate contexts, using Binford's drop/toss zone model, we anticipated the use of all lithic artifacts recovered from within a 3-x-3-m excavation block centered on a feature. The lithic analysis attributes were to include standard metric attributes for the study of projectile points and bifaces and observations on raw material type, dorsal cortex percentage, and maximum dimension on debitage. A more detailed description of these attributes is found in Greaves et al. (n.d.). Finally, we also argued that when it comes to establishing what constitutes overlap or clustering in radiocarbon dates, we would accept an overlap of paired dates at one-sigma.

\section{The Reconstruction of Prehistoric South Texas Moisture Regimes}

Dering $(1994,2002)$ has argued that the anatomical characteristics of wood of the same tree species may vary, in part, in response to local rainfall regimes. Plants growing in wetter environments should have larger and fewer vessels in the wood while the same species growing in dryer environments should have smaller but more numerous vessels. Dering (2002) has demonstrated that modern mesquite in various parts of Texas have characteristics that are consistent with this expectation, and he has begun to amass dated archeological samples that may eventually result in a useful paleoenvironmental record of rainfall variability. Therefore, due to the need for additional information on paleoenvironmental conditions in South Texas, we proposed (Greaves et al. n.d.) to pursue a third research domain, the reconstruction of paleoenvironmental conditions and more specifically moisture regimes during the occupation of the four sites with radiocarbon samples.

Clearly, the identification of charred mesquite samples and their radiocarbon dating would be the key to pursuing the reconstruction of paleoenvironmental conditions in South Texas. In addition, multiple dates would also be critical in establishing the rough contemporaneity of features and feature-proximate artifacts. Therefore, we proposed the following radiocarbon dating strategy. If a feature had a single radiocarbon sample, we proposed to submit two individual charred pieces sufficiently large enough for AMS or standard dating. If a feature had multiple charcoal samples, we proposed to also submit two individual charred pieces sufficiently large enough for AMS or standard dating. To assure that as many pieces of carbonized material as possible submitted for dating would be mesquite species, the submission of samples for dating occurred only after the wood species had been identified and the specimen subsampled for xylem analysis. This approach allowed us to pursue both the feature-focused and paleoenvironmental research themes. 


\section{Results of Analysis}

As mentioned in the preceding brief summary of the research themes, a critical component of investigating lithic technology, and changes in that technology through time, involves establishing the ages of features, with radiocarbon dates on charcoal, and associated lithic debitage for temporal comparison. In an attempt to establish a temporal framework for comparison, CAR selected 16 radiocarbon samples (Table 5-1) from eight feature locations on three sites (41ZV198, 41ZV226, and 41ZV453). Our goal was to submit two samples from each feature area. We suggested that situations where the dates of the two samples from a given feature do not overlap at one-sigma are unlikely to have any integrity, and associated lithic samples are likely to represent mixtures from various time periods. In those cases where the dates do overlap, there is an increased probability that the features, and the associated lithic material, represent assemblages of higher integrity.

Unfortunately, we mistakenly submitted three samples from one feature and only a single sample from a second feature on 41ZV198. This effectively eliminated one of the features from consideration. In addition, while two of the three dates from the second feature overlapped, the third date did not, calling into question the assumption that two dates would be sufficient for establishing feature integrity. Of the six remaining features, five produced overlapping dates, although in two of the five cases the dates are late (ca. A.D. 1520 to 1660 and A.D. 1520 to 1800 ) relative to the presumed prehistoric ages of the associated lithic materials. Four projectile points and one preform are present in two of the associated assemblages in these five features. Comparison of the projectile points further casts doubt on the integrity of the deposits, since in both cases both dart and arrow points are present in the assemblages. Given these results, we have little confidence in the integrity of the associated lithic assemblages, therefore, this aspect of the research was not pursued further.

The paleoenvironmental research domain specifically concerns xylem analysis of dated mesquite charcoal. To pursue this research, the 16 charcoal samples discussed previously were submitted to Dr. Dering for wood identification. He was able to find 11 samples that were mesquite and were large enough to split. One fragment of the split sample was retained by Dering and the second fragment was submitted for dating. This strategy yielded six dated mesquite samples on which xylem analysis was conducted. Given the potential of the technique to reconstruct prehistoric moisture regimes and the utility of the patterns identified by Dering, we present his analysis.

Table 5-1. Radiocarbon Samples Submitted for Analysis

\begin{tabular}{|c|c|c|c|c|c|c|c|c|c|c|}
\hline Sample No. & Site & Unit & Level & Feature & Wood & $\begin{array}{c}\text { Radiocarbon Age } \\
(\mathrm{YBP}+/-1 \delta)\end{array}$ & $\begin{array}{c}\text { Radiocarbon } \delta^{13} \mathrm{C} \\
\text { Corrected Age } \\
(\mathrm{YBP}+/-\mathbf{1 \delta})\end{array}$ & $\begin{array}{c}\text { 1-sigma } \\
\text { Range }\end{array}$ & $\begin{array}{c}\text { 2-sigma } \\
\text { Range }\end{array}$ & $\begin{array}{c}\delta^{13} \mathrm{C}(\text { Years } \\
\text { corrected) }\end{array}$ \\
\hline UGA \#12681 & $41 Z V 226$ & \begin{tabular}{|l|} 
N02/E08 \\
\end{tabular} & 3 & 9 & mesquite & $280 \pm 40$ & $280 \pm 40$ & $1520-1670$ & 1480-1800 & $-24.8(+3)$ \\
\hline UGA \#12682 & 41ZV226 & N02/E08 & 3 & 9 & mesquite & $300 \pm 40$ & $300 \pm 40$ & $1520-1650$ & $1480-1670$ & $-25.24(-43)$ \\
\hline UGA \#12683 & 41ZV226 & N02/E08 & 2 & 8 & mesquite & $300 \pm 40$ & $280 \pm 40$ & $1520-1670$ & $1480-1800$ & $-26.25(-20)$ \\
\hline UGA \#12684 & 41ZV226 & \begin{tabular}{|l|} 
N02/E08 \\
\end{tabular} & 2 & 8 & mesquite & $230 \pm 40$ & $250 \pm 40$ & $1520-1800$ & 1510-1950 & $-23.87(+18)$ \\
\hline UGA \#12685 & 41ZV226 & N02/E06 & 3 & 7 & mesquite & $1070 \pm 40$ & $1080 \pm 40$ & $890-1020$ & $890-1030$ & $-24.57(+7)$ \\
\hline UGA \#12686 & $41 Z V 226$ & N02/E06 & 3 & 7 & mesquite & $1000 \pm 40$ & $1010 \pm 40$ & $980-1160$ & $900-1160$ & $-24.16(+14)$ \\
\hline UGA \#12687 & 41ZV226 & S01/W04 & $3 \& 4$ & 2 & mesquite & $600 \pm 40$ & $610 \pm 40$ & $1300-1400$ & 1290-1410 & $-24.21(+13)$ \\
\hline UGA \#12688 & $41 Z V 226$ & S01/W04 & $3 \& 4$ & 2 & mesquite & $680 \pm 40$ & $680 \pm 40$ & $1280-1390$ & $1270-1400$ & $-24.85(+2)$ \\
\hline UGA \#12689 & $41 Z V 226$ & \begin{tabular}{|l|} 
N01/W04 \\
\end{tabular} & 2 & 1 & mesquite & $960 \pm 40$ & $950 \pm 40$ & $1020-1160$ & $1000-1190$ & $-25.42(-7)$ \\
\hline UGA \#12690 & $41 Z V 226$ & N01/W04 & 2 & 1 & mesquite & $1070 \pm 40$ & $1080 \pm 40$ & $890-1020$ & $890-1030$ & $-24.17(+13)$ \\
\hline UGA \#12691 & $41 Z V 453$ & N04/W0 & 2 & 2 & unkn. & $1080 \pm 40$ & $1060 \pm 40$ & $900-1020$ & $890-1030$ & $-26.22(-20)$ \\
\hline UGA \#12692 & $41 Z$ V453 & N04/W0 & 2 & 2 & unkn. & $1020 \pm 40$ & $1010 \pm 40$ & $980-1160$ & $900-1160$ & $-25.44(-7)$ \\
\hline UGA \#12693 & 41ZV198 & \begin{tabular}{|l|} 
N05/E04 \\
\end{tabular} & 1 & 2 & mesquite & $740 \pm 40$ & $730 \pm 40$ & $1250-1300$ & 1210-1390 & $-25.37(-6)$ \\
\hline UGA \#12694 & \begin{tabular}{|l|}
$41 Z V 198$ \\
\end{tabular} & N0/E02 & 4 & 1 & unkn. & $1560 \pm 40$ & $1570 \pm 40$ & $435-535$ & $410-600$ & $-24.32(+11)$ \\
\hline UGA \#12695 & \begin{tabular}{|l|} 
41ZV198 \\
\end{tabular} & N0/E02 & 4 & 1 & unkn. & $940 \pm 40$ & $940 \pm 40$ & $1020-1160$ & 1010-1190 & $-24.87(+2)$ \\
\hline UGA \#12696 & \begin{tabular}{|l|}
$41 \mathrm{ZV} 198$ \\
\end{tabular} & N0/E02 & 4 & 1 & unkn. & $890 \pm 40$ & $920 \pm 40$ & $1030-1170$ & $1020-1220$ & $-23.40(+26)$ \\
\hline
\end{tabular}




\section{Xylem Analysis of Mesquite Wood Charcoal}

\section{J. Philip Dering}

Xylem analysis was conducted on six mesquite wood charcoal samples from two archeological sites in Zavala County, Texas. The purpose of the study was to provide more baseline data from xylem analysis for the Holocene in southern Texas. The hope is that xylem analysis will eventually provide another proxy data source for determining Holocene environmental history in the region.

\section{Methods}

Tree trunks and limbs function to 1) support the tree, 2) conduct water and minerals from the roots to the leaves, and 3) to conduct food produced by photosynthesis from the leaves to the stems, trunk and roots. Most of a tree is composed of xylem tissue, otherwise known as wood. Xylem is composed of several types of tissues and cells, including vessel elements and rays that conduct water, and several types of fibers that act as structural support for the tree. In seedbearing plants, vessel elements act as the primary conduits for water that is transported from the roots to the leaves.

The shape and arrangement of these cells in xylem is unique to the genus or species of most trees, allowing for trees to be identified from their wood. Charred wood usually retains its anatomical integrity, allowing charcoal to be identified by its characteristic arrangement of cell types.

As a reaction to local environmental conditions, wood anatomy can also vary within the basic pattern of a species. Recent studies in South Africa have demonstrated that trees adapt to differing moisture regimes, and that the anatomical characteristics of wood of the same tree species will vary accordingly. Within the same tree species, vessel elements, the primary water conductors in the wood of a tree, may vary in size and density according to local rainfall regimes (February 1992, 1994; February et al. 1995).

Studies in South Africa have demonstrated that some tree species demonstrate predictable changes in vessel diameter and density according to changes in rainfall regime. Using two commonly occurring species, Protea roupelliae and Protea caffra, that are distributed across a wide range of annual precipitation, February (1994:103) has demonstrated that vessel diameter increases and vessel density decreases as rainfall increases across a geographic gradient. Plants growing in wetter environments have larger and fewer vessels than the same species growing in dryer environments.

In an effort to place the Zavala County samples in an accurate temporal context, identified paired samples were dated. Each sample consisted of a single fragment that was snapped into two pieces. One fragment was utilized to obtain an AMS radiocarbon age and the other fragment was subjected to xylem analysis. Thus, the date and the xylem analysis originated from the same charcoal fragment. Table 5-2 presents the samples, the corrected ${ }^{14} \mathrm{C}$ age, and the onesigma calibrated date-range.

Of the 11 samples presented in Table 5-2, six were selected for xylem analysis. These six fragments provided the largest transverse sections for observation and measurement. The samples range in age from $280 \pm 40 \mathrm{BP}$ to $1080 \pm 40 \mathrm{BP}$, and provide additional xylem measurement data for the Late Prehistoric period in the Rio Grande Valley.

\section{Microscopy and Measurements}

Although previous xylem analysis studies have been conducted using scanning electron microscopy, a light microscope was used for the current analysis. Each specimen was fractured along the transverse (cross-section) plane and secured to a 1-x-1-cm aluminum cylindrical stub using 12$\mathrm{mm}$-wide carbon conductive tape. The analysis utilized an epi-illuminated Leica MZ 125 stereomicroscope operating at ranges from 8 to 125 magnifications. The use of the light microscope drastically reduced sample preparation time. The diameter of each vessel was calculated using the graticule (scale) placed on the stub alongside the sample. Because vessels are shaped irregularly, this ensured that measurements were taken from the same orientation (e.g., tangential diameter) for every sample.

\section{Data Presentation}

Three values were obtained for each wood specimen. The first was the mean vessel diameter for each sample. The second value was the mean of the density of vessels in the wood, a figure expressed in vessels per $\mathrm{mm}^{2}$. To obtain vessel density, all vessel elements are counted and divided by the area of the transverse section of the wood. The third value is termed the vulnerability index. It is the value calculated by dividing the mean vessel diameter by the mean vessel density for each wood sample. A higher vulnerability index results from the presence of fewer but larger vessels in the wood, a condition indicating wetter climate. A lower vulnerability index is a result of numerous but smaller vessels in the wood, a condition encouraged by low rainfall conditions. 
Table 5-2. Radiocarbon Dates on Paired Samples from Sites 41ZV198 and 41ZV226

\begin{tabular}{|c|c|c|c|c|}
\hline Site & Feature & $\begin{array}{l}\text { Sub-sample } \\
\text { Designator }\end{array}$ & Corrected ${ }^{14} \mathrm{C}$ Age & Calibrated 1-sigma Range \\
\hline $41 Z V 226$ & 9 & a & $280 \pm 40$ & AD 1520-1670 \\
\hline $41 Z V 226$ & 9 & c & $300 \pm 40$ & AD $1520-1650$ \\
\hline $41 Z V 226$ & 8 & $\bar{a}$ & $280 \pm 40$ & AD 1520-1670 \\
\hline $41 Z V 226$ & 8 & d & $250 \pm 40$ & AD 1520-1800 \\
\hline $41 Z V 226$ & 2 & $\overline{\mathbf{a}}$ & $\overline{610} \pm 40$ & AD 1300-1400 \\
\hline $41 Z V 226$ & 2 & $\mathrm{~b}$ & $680 \pm 40$ & AD $1280-1390$ \\
\hline & & & & \\
\hline $41 Z V 198$ & 4 & $\mathbf{a}$ & $730 \pm 40$ & AD 1250-1300 \\
\hline & & & & \\
\hline $41 Z V 226$ & 7 & $\mathrm{a}$ & $1080 \pm 40$ & AD 890-1020 \\
\hline $41 Z V 226$ & 7 & b & $1010 \pm 40$ & AD 980-1160 \\
\hline $41 Z V 226$ & 1 & $\mathrm{a}$ & $950 \pm 40$ & AD $1020-1160$ \\
\hline $41 Z V 226$ & $\mathbf{1}$ & b & $1080 \pm 40$ & AD 890-1020 \\
\hline
\end{tabular}

Samples in bold were selected for xylem analysis.

\section{Results}

\section{Modern Reference Specimens}

Mesquite is distributed almost continuously along an eastwest gradient from Brazos County to El Paso County, particularly within the Rio Grande embayment. Because Texas also exhibits a continuous precipitation gradient along an east-west axis, it should be possible to establish a very detailed data set of xylem anatomy.

The reaction of mesquite to rainfall is being assessed by obtaining specimens from five different precipitation regimes. The modern wood samples were collected from six different counties situated along an east-west gradient with annual precipitation ranging from 39 inches $(1,016 \mathrm{~mm})$ to 8 inches $(203 \mathrm{~mm})$. Stems in the modern collection were restricted to a narrow size range. Only stems with a diameter measuring 1.5-3 inches $(4-7.5 \mathrm{~cm})$ were collected. Wood within this size range produces a very effective fire for heating rocks, can be broken and transported with reasonable ease, and is of the size most often encountered at archeological sites (see Shackleton and Prins 1992). The reference mesquite was cured in a woodshed for at least six months, then carbonized in an electric kiln by slowly raising the temperature to $600^{\circ} \mathrm{C}$. Xylem analysis was conducted using the methods outlined for the archeological specimens, using either a scanning electron microscope or a Leica MZ 125 stereomicroscope.
Modern xylem analysis results are presented by county in Table 5-3, along with annual precipitation amounts. There are distinct differences in the density and in the diameter of vessels in each set of wood samples and these changes occur predictably across the rainfall gradient, showing the potential for this approach. If, when the data set is considerably expanded, these distinctions remain, then we will have identified a quantifiable relationship between rainfall and mesquite xylem anatomy. However, many more reference samples need to be processed and analyzed, and more reference specimens from many different soil types and landform locations within a given rainfall regime need to be examined.

\section{Archeological Specimens}

Results of the current analysis are presented in Table 5-4. The vulnerability index, when compared to the modern specimens, suggests that precipitation varied between wetter and drier conditions that were similar to modern conditions as far east as Bexar County (Bexar County sample [Table 5-3] compared to 41ZV226, Feature 2 sample), and as far west as the Trans-Pecos region (Val Verde County sample [Table 5-3] compared to 41ZV226, Feature 1 sample).

While it is possible that the material varies due to position on the landscape, the results are relatively consistent with other data generated by xylem analysis. The vulnerability index increases dramatically during the period A.D. 1300- 
Table 5-3. Xylem Analysis of Modern Referenced Specimens

\begin{tabular}{|c|c|c|c|c|c|}
\hline $\begin{array}{c}\text { Location } \\
\text { (East to West) }\end{array}$ & Sample Size & $\begin{array}{c}\text { Mean Vessel } \\
\text { Diameter }(\mathbf{m m})\end{array}$ & $\begin{array}{c}\text { Vessel Density } \\
(\mathbf{X} / \mathbf{s q} \mathbf{~ m m})\end{array}$ & $\begin{array}{c}\text { Vulnerability } \\
\text { Index }\end{array}$ & $\begin{array}{c}\text { Average Annual } \\
\text { Precipitation }\end{array}$ \\
\hline Brazos County & 6 & 0.09 & 11.1 & 0.0081 & $991 \mathrm{~mm}$ \\
\hline Bexar County & 2 & 0.082 & 15.3 & 0.0054 & $737 \mathrm{~mm}$ \\
\hline Webb County & 2 & 0.062 & 19 & 0.0033 & $510 \mathrm{~mm}$ \\
\hline Kinney County & 3 & 0.062 & 20 & 0.0031 & $561 \mathrm{~mm}$ \\
\hline Val Verde County & 5 & 0.048 & 27 & 0.0018 & $432 \mathrm{~mm}$ \\
\hline El Paso County & 2 & 0.032 & 39 & 0.0008 & $203 \mathrm{~mm}$ \\
\hline
\end{tabular}

Table 5-4. Xylem Analysis of Six Specimens from 41ZV198 and 41ZV226

\begin{tabular}{|c|c|c|c|c|c|c|}
\hline Site & Specimen \# & Feature & $\begin{array}{c}\text { Mean Vessel } \\
\text { Diameter (mm) }\end{array}$ & $\begin{array}{c}\text { Vessel Density } \\
\text { (X/sq. mm) }\end{array}$ & $\begin{array}{c}\text { Vulnerability } \\
\text { Index }\end{array}$ & Time Period \\
\hline 41 ZV226 & $1-\mathrm{a}$ & 9 & 0.059 & 18 & 0.0033 & AD 1520-1670 \\
\hline 41 ZV226 & $2-\mathrm{d}$ & 8 & 0.062 & 17 & 0.0036 & AD 1520-1800 \\
\hline 41 ZV226 & $3-\mathrm{a}$ & 2 & 0.0798 & 12.1 & 0.0066 & AD 1300-1400 \\
\hline $41 Z V 198$ & $4-\mathrm{a}$ & 4 & 0.049 & 25 & 0.0020 & AD 1250-1300 \\
\hline $41 Z V 226$ & 5-b & 7 & 0.0443 & 23 & 0.0019 & AD 980-1160 \\
\hline 41 ZV226 & 6-b & 1 & 0.0453 & 22 & 0.0021 & AD 890-1020 \\
\hline
\end{tabular}

1400, suggesting increased rainfall during that period. The vulnerability index is lowest for the period between A.D. 890 and 1300, an indication of lower precipitation. The period between A.D. 1520 and 1800 measures in the precipitation range encountered in Webb County today.

Table 5-5 presents the results compared to dated archeological samples from other southern Texas sites. The samples in the current study double the number of dated samples from the late Holocene. They suggest that modern conditions began to prevail around 200-300 years ago. They also suggest that between 400 and 650 years ago, conditions moderated with greater precipitation falling during this period. However, the Feature 4 sample from 41ZV198 has a very low vulnerability index, and the Feature 2 sample from 41ZV226 has a relatively higher vulnerability index, and the calibrated ages of these two samples are nearly inseparable at the two-sigma level of confidence. The two samples from 41ZV226 that date to around 1000 BP indicate very dry conditions, as well as the sample from $41 \mathrm{WB} 556$ that dates to $800 \mathrm{BP}$. If the xylem analysis is an accurate proxy measure, then drier conditions prevailed between 800 and 1,100 years ago.

\section{Conclusions of Xylem Analysis and Recommendations}

The use of xylem analysis as a proxy indicator of prehistoric environmental conditions remains a promising, but unproven method. In the current study, both the vessel diameter measurements and counts continue to be consistent within the range of comparable modern material. The data also continue to suggest that changes in mesquite wood charcoal anatomy may have resulted from changes in regional conditions for tree growth during the late Holocene. 
Table 5-5. Vulnerability Index of Dated Mesquite Samples

\begin{tabular}{|c|c|c|c|c|c|}
\hline Site & $\begin{array}{c}\text { Time Period } \\
\text { (years BP) }\end{array}$ & $\begin{array}{c}\text { Mean Vessel } \\
\text { Diameter }(\mathrm{mm})\end{array}$ & Vessel Density & $\begin{array}{c}\text { Vulnerability } \\
\text { Index } \\
\end{array}$ & $\begin{array}{l}\text { Preliminary } \\
\text { Inference } \\
\end{array}$ \\
\hline Webb County & 0 & 0.062 & 19 & 0.0033 & Modern \\
\hline 41WB556 & 150 & 0.064 & 16.5 & 0.0039 & Slightly Wetter \\
\hline $41 Z V 226$ & 250 & 0.062 & 17 & 0.0036 & Modern \\
\hline $41 Z V 226$ & 280 & 0.059 & 18 & 0.0033 & Modern \\
\hline 41WB556 & 400 & 0.0825 & 11 & 0.0075 & Wetter \\
\hline 41WB557 & 600 & 0.076 & 12.5 & 0.0061 & Wetter \\
\hline $41 Z V 226$ & 610 & 0.0798 & 12.1 & 0.0066 & Wetter \\
\hline 41ZV198 & 730 & 0.049 & 25 & 0.0020 & Drier \\
\hline $41 \mathrm{WB} 556$ & 800 & 0.054 & 22 & 0.0025 & Drier \\
\hline $41 Z V 226$ & 1010 & 0.0443 & 23 & 0.0019 & Drier \\
\hline $41 Z V 226$ & 1080 & 0.0453 & 22 & 0.0021 & Drier \\
\hline 41WB437 & 2000 & 0.065 & 22 & 0.0030 & Modern \\
\hline 41WB437 & 3000 & 0.047 & 26 & 0.0018 & Drier \\
\hline 41ZP364 & 4700 & 0.045 & 23 & 0.0020 & Drier \\
\hline
\end{tabular}

Xylem analysis holds promise for two reasons. There is an abundance of mesquite wood in archeological sites and this wood can be easily dated and analyzed, and preliminary studies of modern mesquite wood strongly suggest that the tree does change the specific dimensions of the cells that make up its xylem anatomy but at the same time retains its overall form.

The changes in the wood anatomy of modern specimens are measurable and appear to coincide with differences in annual precipitation. The differences occur on an east-west rainfall gradient from Brazos County at 39 inches $(1,016 \mathrm{~mm})$ to El Paso County at 8 inches $(203 \mathrm{~mm})$, a linear distance of approximately 700 miles $(1,126 \mathrm{~km})$. The long and gradual precipitation gradient between Brazos and El Paso counties provides good potential for establishing a proxy record based on xylem analysis.

The preliminary research on mesquite xylem has provided promising results, however, many questions remain to be answered. In a previous study I suggested three avenues for future research (Dering 2002:214):

1. Establish a large modern reference data set from each major precipitation regime, including samples from most landforms in the region;
2. Subject the data set to statistical analysis to establish the variability of mesquite xylem anatomy within a given precipitation regime; and

3. In all possible situations, pair the xylem analysis of wood charcoal with AMS dates to provide an accurate temporal context.

The current study attempted to address the feasibility of suggestion No. 3, that is, pairing samples and dating them using AMS to achieve the most accurate possible temporal framework for xylem analysis. The results of the current study have demonstrated that this method can work.

At the current time, the most important aspect of mesquite xylem research is the establishment of a large, provenienced, modern database from a number of locations and landforms in the area between Brazos County and El Paso County, with particular attention to the Rio Grande embayment. Although methods have been developed to devise a protocol for collecting, processing, preparing, and measuring mesquite samples, there are too few specimens from varied locations to absolutely determine a modern reference scale. The establishment of a large, modern database would allow the application of statistical procedures to determine variability of xylem measurements within and among each region in the study area. Once the variability of the modern samples is established, it would provide an accurate proxy index for reading the prehistoric samples. 


\section{Chapter Summary and Conclusions}

In this chapter we evaluated the research potential of artifact collections and available data from nine archeological sites investigated by TxDOT personnel. Based on our review of artifact collections and records, we found that only four of the sites (41ZV198, 41ZV202, 41ZV226, and 41ZV453) had the potential to address the two principal research themes that are the focus of this report, namely the reconstruction of changes in lithic technology and prehistoric moisture regimes.

The fact that each of the four sites is multicomponent presented several methodological challenges in defining appropriate analytical units for study. Following careful evaluation, we proposed that the appropriate unit of analysis that has the potential to yield significant data related to the two research themes was the feature and feature-proximate lithic assemblages and feature-derived, dated, charred mesquite samples.

We offered solutions to several methodological challenges related to the definition of what constitute feature-proximate artifact collections and how to define broad contemporaneity when faced with multiple radiocarbon dates from the same feature. In the end, however, our analysis of the artifacts that fell within the feature-proximate context defined for this study indicated that while some of the paired dates may overlap at one-sigma, the presence of temporal diagnostics spanning several thousand years found in the same featureproximate context caused us to lose confidence in our starting assumptions and the analytical strategy. Therefore, we abandoned the originally proposed research related to changes in lithic technology as manifested in featureproximate lithic assemblages.

While the technological analysis theme was not fruitful, the reconstruction of prehistoric moisture regimes did produce some very important patterns and results. Dering concludes that modern precipitation conditions began to be established roughly 200-300 years ago in South Texas. Between 400 and 650 years ago, greater precipitation seems to have been present, with very dry conditions prevailing between 800 and 1,100 years ago. Overall, these moisture regime patterns reconstructed from mesquite xylem agree well with changes in arboreal/grass pollen during the last 1,000 years as reconstructed from Central Texas bogs (Bousman 1998). These results clearly establish the potential of the technique, and if confirmed by additional work in the region, provide important data for the reconstruction of one aspect of paleoclimate that could not easily be assessed for South Texas. 



\section{Chapter 6: Summary}

\section{Raymond P. Mauldin and Russell D. Greaves}

Between April 1981 and December 1982, staff archeologists from the Texas Department of Transportation surveyed, mapped, and tested a series of localities with exposed cultural materials and features along an approximately 13-km (eight-mile) segment of FM 481 in northwestern Zavala County, Texas. The fieldwork was part of an evaluation of the impacts of road improvements to FM 481. This report provides a comprehensive summary of the work conducted by TxDOT during the FM 481 project and discusses the results of specialized analyses carried out on data types collected during the original fieldwork. The determination of National Resister of Historic Places eligibility and State Archeological Landmark designation for the localities tested by TxDOT personnel was not a goal of the CAR reporting and analysis activities. This report was produced under Work Authorization \#57015PD004 issued to CAR by TxDOT.

Our review of the field notes and maps indicates that some level of work was conducted at what we now classify as nine different sites along the highway. These are 41ZV197, 41ZV198, 41ZV201, 41ZV202, 41ZV226, 41ZV450, $41 Z V 451,41 Z V 452$, and 41ZV453. The work conducted at these sites was highly variable, and much of the effort was undertaken under what can best be described as salvage conditions. Excavations were conducted at several sites, including 41ZV197, 41ZV198, 41ZV202, 41ZV226, 41ZV451, and 41ZV453, while sites 41ZV201, 41ZV450, and 41ZV452 only had mapping. Overall, the level of subsurface testing was low, although a significant volume of sediment was removed at some sites (e.g., 41ZV226). Documentation of what occurred at several locations was minimal (see Greaves et al. n.d.).

As outlined in Chapter 4, the sites along the FM 481 rightof-way are dominated by Late Archaic and Late Prehistoric remains. The sites seem to be characterized by small, dispersed, burned rock features associated with scattered artifacts. Like many sites in South Texas, the recovered artifacts suggest that multiple components are present on most sites. The multicomponent characteristics of these sites limit their research potential, at least at a site level.

As discussed in Chapter 5, CAR had previously suggested that features and individual charcoal samples could be used as the minimal analytical unit for limited analysis designed to investigate changes in lithic technology and aspects of paleoclimate (Greaves et al. n.d.). We attempted to assess feature integrity by the submission of multiple radiocarbon dates $(n=16)$ from eight different feature contexts. In cases where dates did not overlap at one-sigma, features, and their associated assemblages, were assumed to have little integrity. In five cases feature dates did overlap. While these features appear to have higher integrity, comparison of the date ranges to the associated diagnostic artifacts suggest that the associated assemblages are mixed. Given these results, we had little confidence in the integrity of the associated lithic assemblages, and further research into lithic technology was not pursued. The investigation into paleoenvironmental research focused on xylem analysis of mesquite and used a subset of the charcoal dates from features. As Phil Dering's discussion in Chapter 5 demonstrates, this portion of the investigation was certainly successful. The xylem analysis of dated mesquite allowed at least preliminary conclusions regarding relative change in rainfall in the region. These results clearly establish the potential of the technique and provide important preliminary data for the reconstruction of one aspect of paleoclimate that previously could not easily be assessed for South Texas.

Overall, the fieldwork conducted by TxDOT and the analyses performed by CAR suggest that sites such as those tested along FM 481 represent a relatively common remnant of hunter-gatherer land use within the region. In particular, the presence of sites with multiple burned rock hearth features spread over large areas and characterized by dispersed radiocarbon dates suggest repeated use of the landscape and locality for relatively similar purposes. While the multiple features most likely represent a slowly accumulated palimpsest, these sites suggest a high degree of consistency in land-use strategies and resource structure over a relatively long period. This low-level but consistent reuse of specific localities, in the context of apparently very similar land-use strategies, probably occurred in other parts of the state as well but its archeological manifestation is very different in South Texas. For instance, while in Central Texas reuse of the landscape is manifested in low-visibility camp sites characterized by spatially concentrated hearths, discard and generalized activity areas, in South Texas site reuse is expansive, forming large sites with widely spaced hearth features and few concentrated deposits that resemble the midden (i.e., trash dump) deposits seen in Central Texas. 
The reasons underlying these regionally distinct site formation processes is unknown, but it may relate to a series of factors including differences in the structure of the resources, primary and secondary biomass productivity, and perhaps culturally dictated phenomena. Because archeologists do not understand the resource context within which these sites were formed nor have they documented the periodicity of landscape use as reflected by these multiple features, similar South Texas sites have much to contribute to understanding hunter-gatherer adaptations within the xeric South Texas landscape. While expansive sites with large numbers of hearths may represent long periods of reuse, and thus represent unusual methodological challenges, an emphasis on more feature-focused or feature-proximate analytical units rather than site-level analytical units may allow the pursuit of regional research questions and National Register of Historic Places and State Archeological Landmark eligibility without being limited by their lengthy periods of reuse. 


\section{References Cited}

Barnes, V. E.

1977 Geologic Atlas of Texas: Del Rio Sheet. Bureau of Economic Geology, The University of Texas at Austin.

1983 Geologic Atlas of Texas: San Antonio Sheet. Bureau of Economic Geology, The University of Texas at Austin.

Binford, L. R.

1978 Dimensional Analysis of Behavior and Site Structure: Learning from an Eskimo Hunting Stand. American Antiquity 43:330-361.

Black, S. L.

1986 The Clemente and Herminia Hinojosa Site, 41JW8: A Toyah Horizon Campsite in Southern Texas. Special Report No. 18. Center for Archaeological Research, The University of Texas at San Antonio.

1989 South Texas Plain. In From the Gulf Coast to the Rio Grande: Human Adaptation in the Central, South, and Lower Pecos Texas, by T. R. Hester, S. L. Black, D. G. Steele, B. W. Olive, A. A. Fox, K. J. Reinhard, and L. C. Bement, pp. 39-62. Research Series No. 33. Arkansas Archeological Survey, Fayetteville.

Blair, W. F.

1950 The Biotic Provinces of Texas. Texas Journal of Science 2(1):93-117.

Bousman, C. B.

1998 Paleoenvironmental Change in Central Texas: The Palynological Evidence. Plains Anthropologist 164:201-219.

Brown, K. M., D. R. Potter, G. D. Hall, and S. L. Black

1982 Excavations at 41LK67, A Prehistoric Site in the Choke Canyon Reservoir, South Texas. Choke Canyon Series, vol. 7. Center for Archaeological Research, The University of Texas at San Antonio.

Brownlow, R. K.

2003 Archeological Investigations at 41WM815, A Blackland Prairie Site, Williamson County, Texas. Archeology Studies Program, Report No. 23. Environmental Affairs Division, Texas Department of Transportation, Austin.

Bryant, V. M., Jr., and R. G. Holloway

1985 A Late-Quaternary Paleoenvironmental Record of Texas: An Overview of the Pollen Evidence. In Pollen Records of Late-Quaternary North American Sediments, edited by V. M. Bryant, Jr. and R. G. Holloway, pp. 39-70. American Association of Stratigraphic Palynoligists Foundation, Dallas.

Campbell, T. N., and T. J. Campbell

1981 Historic Indians of the Choke Canyon Reservoir and Surrounding Area, Southern Texas. Choke Canyon Series, vol. 1. Center for Archaeological Research, The University of Texas at San Antonio.

Chandler, C. K.

1992 A Polyhedral Blade Core from Northeast San Antonio, Bexar County, Texas. La Tierra 19(4):20-25.

Collins, M. B.

1995 Forty Years of Archeology in Central Texas. Bulletin of the Texas Archeological Society 66:361-400. 
Collins, M. B., and P. J. Headrick

1992 Comments on Kelly's Interpretations of the "Van Autry" Cores. La Tierra 19(4):26-39.

Collins, M. B., D. B. Hudler, and S. L. Black

2003 Pavo Real (41BX52): A Paleoindian and Archaic Camp and Workshop on the Balcones Escarpment, Southcentral Texas. Studies in Archeology No. 41, Texas Archeological Research Laboratory, The University of Texas at Austin. Archeological Studies Program, Report 50, Environmental Affairs Division, Texas Department of Transportation, Austin.

Creel, D., A. J. McGraw, F. Valdez, Jr., and T. C. Kelly

1979 Excavations at 41LK106, A Prehistoric Occupation Site in Live Oak County, Texas. Archaeological Survey Report, No. 62. Center for Archaeological Research, The University of Texas at San Antonio.

Davis, W. B., and D. J. Schmidly

1994 The Mammals of Texas. Texas Parks and Wildlife, Austin.

Dering, J. P.

1994 Appendix D: Plant Remains from 41GM224, Grimes County, Texas. In Excavations at Site 41GM224 in the Gibbons Creek Lignite Mine Permit 38A Area, Grimes County, Texas, by R. Rogers. Espey, Huston and Associates, Inc., Austin.

2000 Appendix B: Macrobotanical Analyses Identification of Carbonized Plant Remains and EDXA Studies of Mesquite Wood from 41WB347 Using Scanning Electron Microscopy. In The Lino Site: A Stratified Late Archaic Campsite in a Terrace of San Idelfonzo Creek, Webb County, Southern Texas, by J. M. Quigg, C. Lintz, G. Smith, and S. Wilcox. Technical Report No. 23756, TRC Mariah Associates; Archeological Studies Program, Report No. 20, Environmental Affairs Division, Texas Department of Transportation, Austin.

2002 Rainfall Reconstruction Using Mesquite Wood Charcoal from Archeological Sites in South Texas. In Archeological Data Recovery Excavations along Becerra Creek (41WB556), Webb County, Texas, by R. B. Mahoney, R. P. Mauldin, and S. A. Tomka, pp. 206-216. Archaeological Survey Report, No. 321, Center for Archaeological Research, The University of Texas at San Antonio. Archeological Studies Program, Report No. 30, Environmental Affairs Division, Texas Department of Transportation, Austin.

Dillehay, T.

1974 Late Quaternary Bison Population Changes on the Southern Plains. Plains Anthropologist 19(64):180-196.

February, E. C.

1992 Archaeological Charcoals as Indicators of Vegetation Change and Human Fuel Choice in the Late Holocene at Elands Bay, Western Cape Province, South Africa. Journal of Archaeological Science 19:347-354.

1994 Rainfall Reconstruction Using Wood Charcoal from Two Archaeological Sites in South Africa. Quaternary Research 42:100-107.

February, E. C., W. D. Stock, W. J. Bond, and D. Le Roux

1995 Relationships Between Water Availability and Selected Vessel Characteristics in Eucalyptus Grandis and Two Hybrids. IAWA Bulletin 16:269-276.

Foik, P. J.

1933 Captain Don Domingo Ramón's Diary of His Expedition into Texas in 1716. Preliminary Studies of the Texas Catholic Historical Society, Volume II, Number 5:2-23. 
Foster, W. C.

1995 Spanish Expeditions into Texas, 1689-1768. University of Texas Press, Austin.

Goode, G. T.

2002 The Anthon Site: A Prehistoric Encampment in Southern Uvalde County, Texas. Archeological Studies Program, Report No. 38. Environmental Affairs Division, Texas Department of Transportation, Austin.

Greaves, R. D., S. A. Tomka, B. Moses, and R. Mauldin

n.d. An Assessment of Selected Archeological Sites along FM 481, Zavala County, Texas. Prepared for Environmental Affairs Division, Texas Department of Transportation, Austin. Unpublished document on file Center for Archaeological Research, The University of Texas at San Antonio.

Griffen, W. B.

1969 Cultural Change and Shifting Populations in Central Northern Mexico. Anthropological Papers of the University of Arizona, Number 13. The University of Arizona Press, Tucson.

1979 Indian Assimilation in the Franciscan Area of Nueva Vizcaya. Anthropological Papers of the University of Arizona, Number 33. The University of Arizona Press, Tucson.

Hackett, C. W. (editor and translator)

1971[1931] Pichardo's Treatise on the Limits of Louisiana and Texas. Volume II. Books for Libraries Press, Freeport, New York.

Hall, G. D.

1985 Comparative Ecologies: The Texas Chaparral Versus the Australian Outback. La Tierra 12(3):6-19.

Hall, G. D., S. L. Black, and C. Graves

1982 Archaeological Investigations at the Choke Canyon Reservoir, South Texas: The Phase I Findings. Choke Canyon Series, vol. 5. Center for Archaeological Research, The University of Texas at San Antonio.

Hall, G. D., T. R. Hester, and S. L. Black (editors)

1986 The Prehistoric Sites at Choke Canyon Reservoir, Southern Texas: Results of the Phase II Archaeological Investigations. Choke Canyon Series, vol. 10. Center for Archaeological Research, The University of Texas at San Antonio.

Hard, R. J., A. A. Fox, I. W. Cox, K. J. Gross, B. A. Meissner, G. I. Méndez, C. L. Tennis, and J. E. Zapata

1995 Excavations at Mission San José y San Miguel de Aguayo, San Antonio, Texas. Archaeological Survey Report, No. 218. Center for Archaeological Research, The University of Texas at San Antonio.

Hartle, D. D., and R. L. Stephenson

1951 Archaeological Excavations at the Falcon Reservoir, Starr County, Texas. In River Basin Surveys, prepared for the Smithsonian Institution, Washington D.C.

Henderson, J.

1981 Site notes on recording and testing of sites along FM 481 in Zavala County. On file at Environmental Affairs Division, Texas Department of Transportation, Austin.

1982 Site notes on recording and testing of sites along FM 481 in Zavala County. On file at Environmental Affairs Division, Texas Department of Transportation, Austin. 
Hester, T. R.

1969 Archeological Investigations in Kleberg and Kenedy Counties, Texas. SBC Archeological Report No. 15, Draft. Texas Archeological Research Laboratory, The University of Texas, Austin.

1978 Background to the Archaeology of Chaparrosa Ranch, Southern Texas. Volume 1: Studies in the Archaeology of Chaparrosa Ranch. Special Report, No. 6. Center for Archaeological Research, The University of Texas at San Antonio.

1980 Digging into South Texas Prehistory. Corona, San Antonio.

1995 The Prehistory of South Texas. Bulletin of the Texas Archeological Society 66:427-460.

Hester, T. R., L. White, and J. White

1969 Archeological Materials from the Oulline Site (41LS3) and Other Sites in La Salle County, Texas. Texas Journal of Science 21(2):131-166.

Houk, B. A., K. Lawrence, and K. Miller

2003 An Archeological Survey and Geoarcheological Evaluation of Portions of FM 481 in Zavala County, Texas. SWCA Environmental Consultants, Archeological Survey Report, Eight Properties, Unpublished document on file Texas Environmental Affairs Division, Department of Transportation, Austin.

Houk, B.A., S. A. Tomka, B. Bousman, C. K. Chandler, B. Moses, M. Renner, and M. Lyons

1997 The Greenbelt Core: A Polyhedral Blade Core from San Antonio, Texas. Current Research in the Pleistocene 14:104-106.

Inman, B. J., T. C. Hill, Jr., and T. R. Hester

1998 Archeological Investigations at the Tortuga Flat Site, 41ZV155, Southern Texas. Bulletin of the Texas Archeological Society 69:11-33.

Johnson, L., Jr., and G. T. Goode

1994 A New Try at Dating and Characterizing Holocene Climates, as well as Archaeological Periods on the Eastern Edwards Plateau. Bulletin of the Texas Archeological Society 65:1-51.

Kelly, T. C.

1992 Two Polyhedral Cores from Comanche Hill, San Antonio, Texas. La Tierra 19(2):29-33.

Kumpe, D., R. McReynolds, and C. K. Chandler

2000 A Highly Serrated Arrow Point from Falcon Reservoir, Zapata County, Texas. La Tierra 27(1):33-45.

Largent, F. B., M. R. Waters, and D. L. Carson

1991 The Spatiotemporal Distribution and Characteristics of Folsom Projectile Points in Texas. Plains Anthropologist 36(137):323-342.

Lukowski, P. D.

1987 Archaeological Investigations Along the Leona River Watershed, Uvalde County, Texas. Archaeological Survey Report, No. 132. Center for Archaeological Research, The University of Texas at San Antonio.

Mahoney, R. B. , R. P., Mauldin, and S. A. Tomka

2002 Archeological Data Recovery Excavations Along Becerra Creek (41WB556), Webb County, Texas. Archaeological Survey Report, No. 321, Center for Archaeological Research, The University of Texas at San Antonio. Archeological Studies Program, Report No. 44, Environmental Affairs Division, Texas Department of Transportation, Austin. 
McGraw, A. J., J. W. Clark, and E. A. Robbins (editors)

1998 A Texas Legacy: The Old San Antonio Road and the Caminos Reales, A Tricentennial History, 1691-1991. Second Printing. Texas Department of Transportation, Austin.

McGraw, A. J., and K. Hindes

1987 Chipped Stone and Adobe: A Cultural Resources Assessment of the Proposed Applewhite Reservoir, Bexar County, Texas. Archaeological Survey Report, No. 163. Center for Archaeological Research, The University of Texas at San Antonio.

McGraw, A. J., and D. A. Knepper

1983 The East Chacon Project: 11,000 Years of Prehistory along the Upper Nueces River, Southern Texas. Archaeological Survey Report No. 125 (1983). Unpublished document on file Center for Archaeological Research, The University of Texas at San Antonio.

Meltzer, D. J., and M. R. Bever

1995 Paleoindians of Texas: An Update on the Texas Clovis Fluted Point Survey. Bulletin of the Texas Archeological Society 66:47-81.

Miller, K. A., O. S. Carpenter, L. C. Nordt, and C. W. Ringstaff

2000 Archaeological Investigations Along the Camino Colombia Toll Road, Webb County, Texas. SWCA Cultural Resource Report, No. 97-120. SWCA, Inc., Environmental Consultants, Austin.

Miller, K. A., A. O'Farrell, and D. D. Kuehn

2002 Archaeological Survey Report: Enhancement of FM 481, Zavala County. SWCA, Inc., Austin, Texas.

Montgomery, J. L.

1978 The Mariposa Site: A Late Prehistoric Site on the Rio Grande Plain of Texas. Special Report, No. 6. Center for Archaeological Research, The University of Texas at San Antonio.

National Climate Data Center

2004 Online Climate Data for Austin, Texas. <http://lwf.ncdc.noaa.gov/oa/climate/climatedata.html>.

Natural Fibers Information Center

1987 The Climates of Texas Counties. The University of Texas at Austin.

Nordt, L. C.

1998 Chapter 7: Geoarcheology of the Rio Grande and Elm Creek in the Vicinity of Site 41MV120. In 41MV120: A Stratified Late Archaic Site in Maverick County, Texas, edited by B. J. Vierra, pp. 43-77. Archaeological Survey Report, No. 251, Center for Archaeological Research, The University of Texas at San Antonio. Archeological Studies Program, Report No. 7, Environmental Affairs Division, Texas Department of Transportation, Austin.

Nordt, L. C., T. W. Boutton, J. S. Jacob, and R. Mandel

1994 Late Quaternary Climates of Central Texas Based on the Stable Isotopic Composition of Organic Carbon. Program and Abstracts, $52^{\text {nd }}$ Plains Conference, $65^{\text {th }}$ Annual Meeting of the Texas Archeological Society, Lubbock.

Nunley P., and T. R. Hester

1966 Preliminary Archeological Investigations in Dimmit County, Texas. Texas Journal of Science 18:233-253. 
O’Connell, J.

1987 Alyawara Site Structure and Its Archaeological Implications. American Antiquity 52:74-108.

O'Farrell, A., and K. Miller

2002 Archaeological Survey and Testing of Seven Archaeological Sites and the West Side of Turkey Creek. Enhancement of FM 481 from Uvalde Co. Line to Maverick Co. Line. SWCA consultants. Unpublished document on file Center for Archaeological Research, University of Texas at San Antonio.

Perttula, T. K.

2001 Hunter-Gatherer Mortuary Practices in the Rio Grande Plains and Central Coastal Plains Archeological Regions of Texas. La Tierra 28(3/4):2-83.

Quigg, J. M.

2000 Appendix M: Stable Carbon and Nitrogen Isotope Data on Modern Plant and Animal Resources from South Texas. In Data Recovery at 41ZP364: An Upland Campsite at Falcon Reservoir, Zapata County, Texas, by J. M. Quigg and C. Cordova, pp. 353-364. Technical Report No. 22317. TRC Mariah Associates, Inc., Austin.

Quigg, J. M., C. Lintz, G. Smith, and S. Wilcox

2000 The Lino Site: A Stratified Late Archaic Campsite in a Terrace of San Idelfonzo Creek Webb County, Southern Texas. Technical Report No. 23756, TRC Mariah Associates. Archeological Studies Program, Report No. 20, Environmental Affairs Division, Texas Department of Transportation, Austin.

Quigg, J. M., S. Pritchard, and G. Smith

2002 The Boiler Site (41WB557): Utilization of an Upland Setting Over the Last 4200 Years, Webb County, Texas. Technical Report No. 27277, TRC Mariah Associates. Archeological Studies Program, Report No. 45, Environmental Affairs Division, Texas Department of Transportation, Austin.

Ramsey, C. B.

2000 OxCal Program Version 3.5. Radiocarbon Accelerator Unit, University of Oxford. Oxford, U.K.

Robbins, E. A.

1998 The First Routes into Texas. In A Texas Legacy: The Old San Antonio Road and The Caminos Reales, A Tricentennial History, 1691-1991, edited by A. J. McGraw, J. W. Clark, and E. A. Robbins, pp. 61-113. Second Printing. Environmental Affairs Division, Texas Department of Transportation, Austin.

Robinson, R. L.

1979 Biosilica and Climate Change at 41GD21 and 41GD21A. In Archaeological Investigations of Two Prehistoric Sites on the Coleto Creek Drainage, Goliad County, Texas. Archaeological Survey Report, No. 69. Center for Archaeological Research, The University of Texas at San Antonio.

1982 Biosilica Analysis of Three Prehistoric Archaeological Sites in the Choke Canyon Reservoir, Live Oak County, Texas: Preliminary Summary of Climatic Implications. In Archaeological Investigations at Choke Canyon Reservoir, South Texas: The Phase I Findings, edited by G. D. Hall, S. L. Black and C. Graves, pp. 597-610. Choke Canyon Series, vol. 5. Center for Archaeological Research, The University of Texas at San Antonio.

Scott, R. F., and D. E. Fox

1982 Excavations at Sites 41LK31/32 and 41LK202 in the Choke Canyon Reservoir, South Texas. Choke Canyon Series, vol. 8. Center for Archaeological Research, The University of Texas at San Antonio. 
Shackleton, C. M., and F. Prins

1992 Charcoal Analysis and the "Principle of Least Effort." Journal of Archaeological Science 19:631-637.

Shafer, H. J., and T. R. Hester

1971 A Study of the Function and Technology of Certain Bifacial Tools from Southern Texas. Archeological Report No. 20, Texas Historical Survey Committee, Austin.

Southern Regional Climate Center (SRCC)

2003a Normal Daily Minimum Temperature. $<$ http://www.srcc.lsu.edu/7100/tmin/USMap.html> Accessed December 2003.

2003b Normal Daily Maximum Temperature. <http://www.srcc.lsu.edu/7100/tmax/TX.html > Accessed December 2003.

2003c Normal Monthly Precipitation. <http://www.srcc.lsu.edu/7100/prcp/TX.html> Accessed December 2003.

Stahle, D. W., and M. K. Cleaveland

1988 Texas Drought History Reconstructed and Analyzed from 1698 to 1980. Journal of Climate 1:59-74.

Stevens, J. W., and D. Arriaga

1985 Soil Survey of Dimmit and Zavala Counties, Texas. United States Department of Agriculture. Washington, D.C.

Stevenson, M. G.

1991 Beyond the Formation of Hearth-Associated Artifact Assemblages. In The Interpretation of Archaeological Spatial Patterning, edited by E. M. Kroll and T .D. Price, pp. 269-299. Plenum Press, New York.

Stever, R. H.

2004 Stagecoach Lines. The Handbook of Texas Online $<$ http://www.tsha.utexas.edu/handbook/online/ $>$ Accessed 2004.

Stuiver, M., P. J. Reimer, E. Bard, J. W. Beck, G. S. Burr, K. A. Hughen, B. Kromer, B. McCormac, J. van der Plicht, and M. Spurk

1998 INTCAL98 Radiocarbon Age Calibration, 24,000-0 cal BP. Radiocarbon 40(3):1041-1083.

Taylor, A. J., and C. L. Highley

1995 Archeological Investigations at the Loma Sandia Site (41LK28): A Prehistoric Cemetery and Campsite in Live Oak County, Texas. 2 volumes. Studies in Archeology No. 20. Texas Archeological Research Laboratory, The University of Texas at Austin.

Texas Parks and Wildlife Department (TPWD)

1999 TPWD GIS Data. On file Center for Archaeological Research, The University of Texas at San Antonio.

Therrell, M. D.

2000 The Historic and Paleoclimatic Significance of Log Buildings in Southcentral Texas. Historical Archaeology 34(2):25-37.

Tomka, S. A.

1999 A Multiple-fluted Folsom Manufacture Failure from South Texas. Current Research in the Pleistocene 16:79-81. 
Tous, G.

1930 Ramón Expedition: Espinosa's Diary of 1716. Preliminary Studies of the Texas Catholic Historical Society, Volume I, Number 4:2-24.

Turner, E. S., and T. R. Hester

1999 A Field Guide to Stone Artifacts of Texas Indians. 3rd Edition. Gulf Publishing, Houston.

Vierra, B. J.

1998 41MV120: A Stratified Late Archaic Site in Maverick County, Texas. Archaeological Survey Report, No. 251. Center for Archaeological Research, The University of Texas at San Antonio.

Wade, $M$.

2003 The Native Americans of the Texas Edwards Plateau, 1582-1799. The University of Texas Press, Austin. 
Appendix A

\section{Radiocarbon Results}




\section{(T) \\ The University of Georgia}

Center for Applied Isorope Smdics

\section{RADIOCARBON AGE ANALYSIS REPORT}

Dr. James T. Abbott

November 11, 2003

Staff Geoarcheologist

Cultural Resources Management

Texas Department of Transportation

Dewitt C. Greer State Highway Bidg.

125 E. 11th Street

Austin, TX $78701-2483$

Dear Dr. Abbott,

Enclosed please find the results for the Radiocarbon $\left({ }^{4} \mathrm{C}\right)$ analyois including Stable Isotope Ratio analysis $\left(\delta^{13} \mathrm{C}\right)$ correction for the charcoal samples received by our laboratory on October 3, 2003.

\begin{tabular}{|c|c|c|c|c|}
\hline UGA\# & $\begin{array}{l}\text { Sample } \\
\text { I.D. }\end{array}$ & $\begin{array}{c}\text { Radiocarbon } \\
\text { Age } \\
\text { (YBP } \pm 1 \sigma)\end{array}$ & $\begin{array}{l}\text { Radiocarbon } \\
\delta^{23} \text { C Corrected } \\
\text { Age (YBP } \pm 10)\end{array}$ & $\begin{array}{l}\delta^{13 \hat{C}} \\
\text { Years } \\
\text { corrected) }\end{array}$ \\
\hline 12681 & $412 V 226-60-6-a:$ & $280 \pm 40$ & $280 \pm 40$ & $-24.80(+3)$ \\
\hline 12682 & 41ZV226-60-6-c: & $300 \pm 40$ & $300 \pm 40$ & $-25.24(-4)$ \\
\hline 12683 & 41ZV226-8a-1-a: & $300 \neq 40$ & $280 \pm 40$ & $-26.25(-20)$ \\
\hline 12684 & $41 \mathrm{ZV} 226-8 \mathrm{a}-1-\mathrm{d}:$ & $230 \pm 40$ & $250 \pm 40$ & $-23.87(+18)$ \\
\hline 12685 & 41ZV226-5a-1-a: & $1,070 \pm 40$ & $1.080 \pm 40$ & $.24 .57(+7)$ \\
\hline 1.2686 & 4lZV226-5a-1-b: & $1,000 \pm 40$ & $1,010 \pm 40$ & $-24.16(+14)$ \\
\hline 12687 & 4IZV226-78-4-a: & $600 \pm 40$ & $610 \pm 40$ & $-24.21(+13)$ \\
\hline 12688 & 41ZV226-78-4-b: & $680 \pm 40$ & $680 \pm 40$ & $-24.85(+2)$ \\
\hline 12689 & 41ZV226-z-3-3-2: & $960 \pm 40$ & $950 \pm 40$ & $-25.42(-7)$ \\
\hline 12690 & 4.12V226-z-3-3-b: & $1,070 \pm 40$ & $1,080 \pm 40$ & $-24.17(+13)$ \\
\hline 12691 & 412V203-8-3-1: & $1,080 \pm 40$ & $1,060 \pm 40$ & $-26.22(-20)$ \\
\hline 12692 & $412 V 203-8-3-2:$ & $1,020 \pm 40$ & $1,010 \pm 40$ & $-25.44(-7)$ \\
\hline 12693 & $4 \cdot 12 V 198-4-a+10-a$ & $740 \pm 40$ & $730 \pm 40$ & $.25 .37(-6)$ \\
\hline 12694 & $41 Z V 198 \cdot 1-0-28-2:$ & $1,560 \pm 40$ & $1,570 \pm 40$ & $-24.32(+11)$ \\
\hline 12695 & 41ZV198-1-d-8-2: & $940 \pm 40$ & $940 \pm 40$ & $-24.87(+2)$ \\
\hline 12696 & $41 Z V 198-1 \cdot 0-28-1:$ & $890 \pm 10$ & $920 \pm \frac{4}{2} 0$ & $-23.40(+26)$ \\
\hline
\end{tabular}


Radiocarbon determination

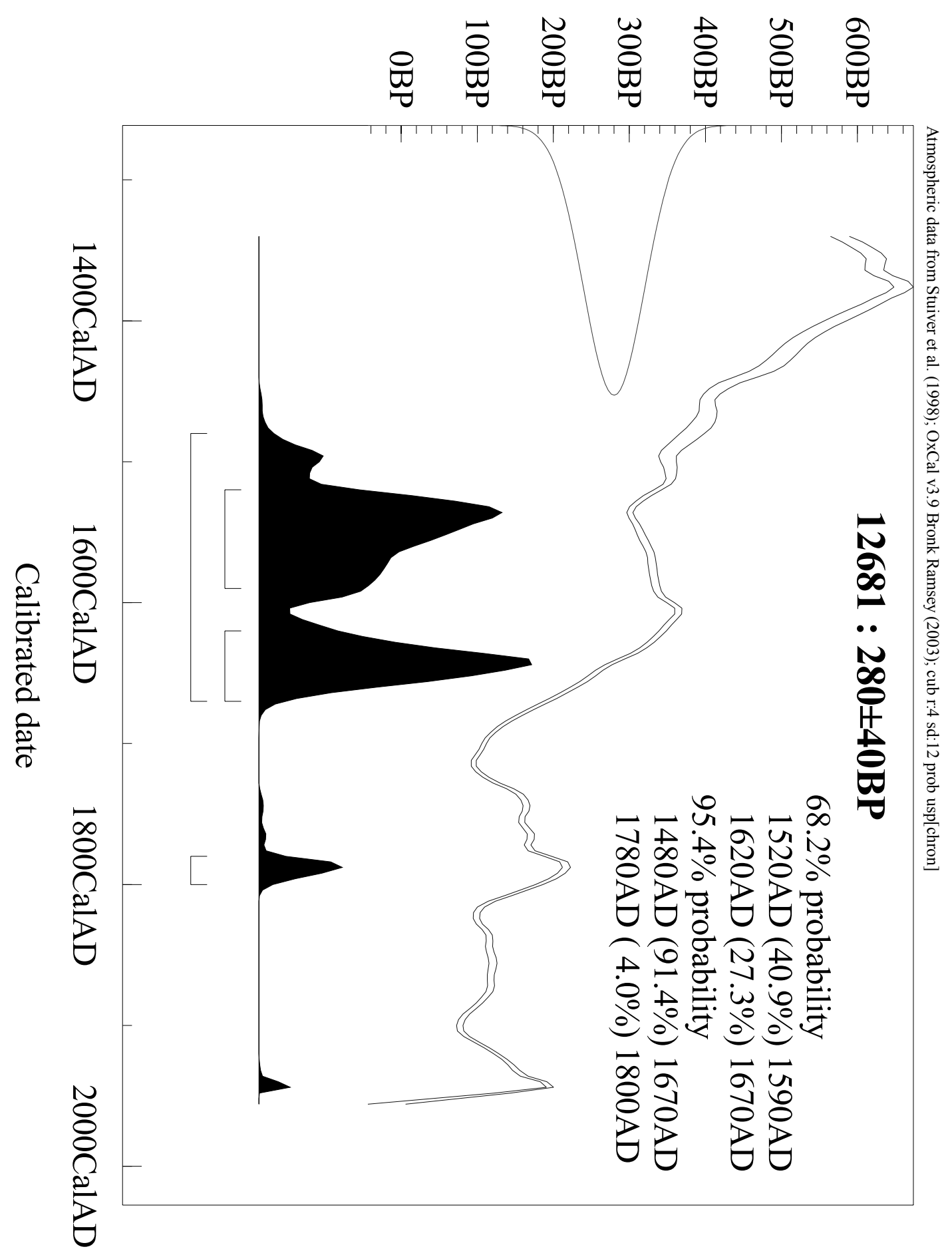


Radiocarbon determination

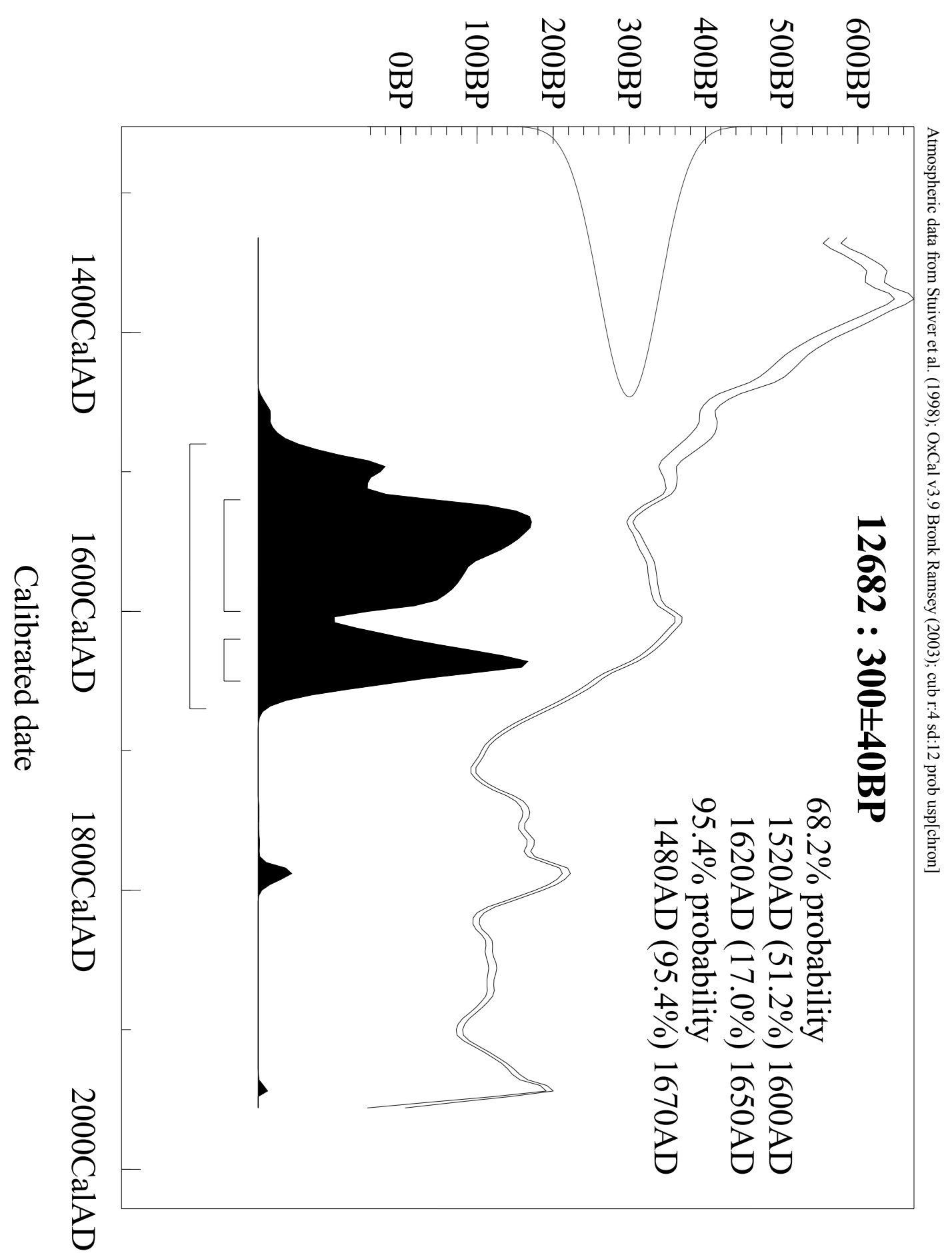




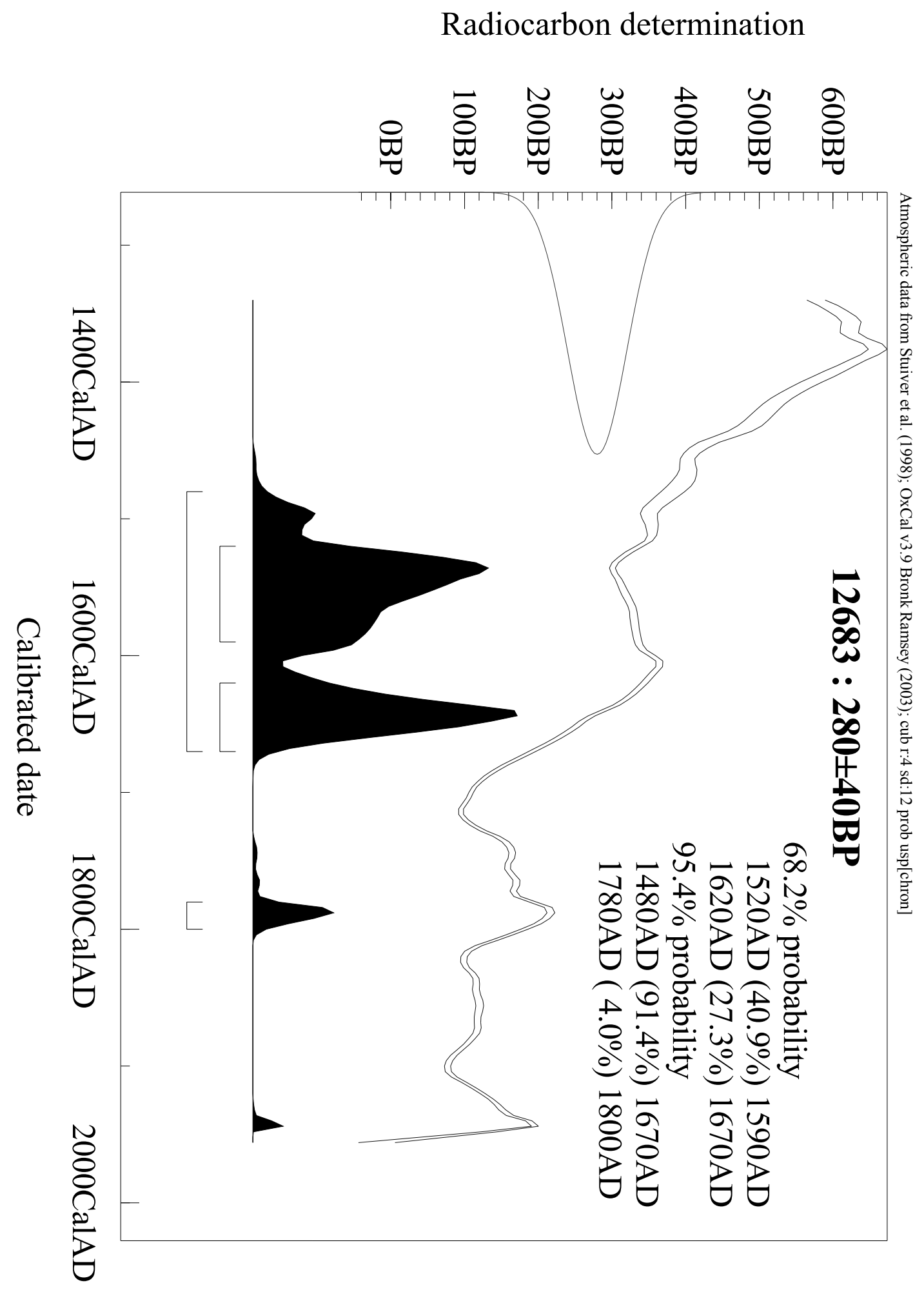


Radiocarbon determination

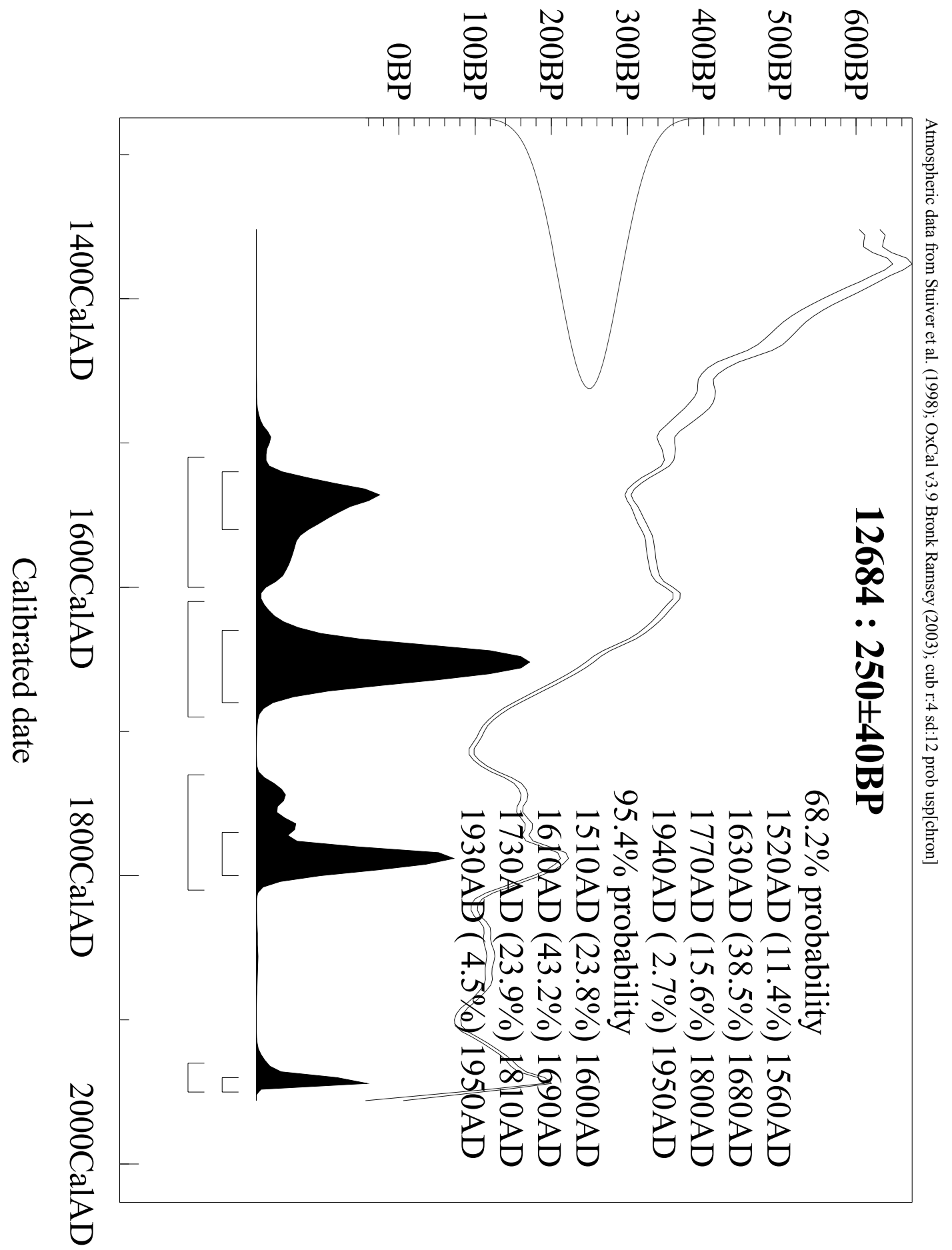




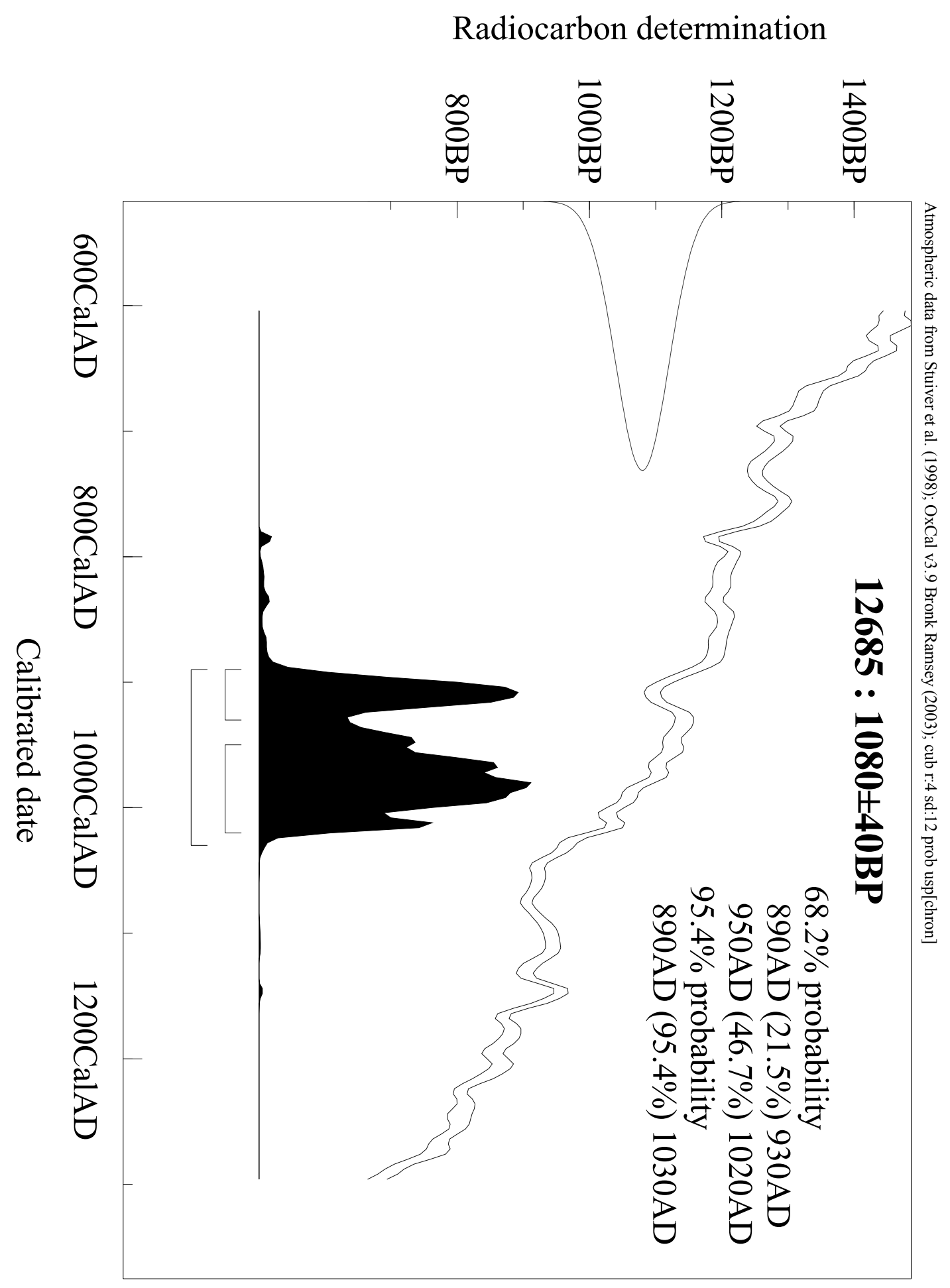




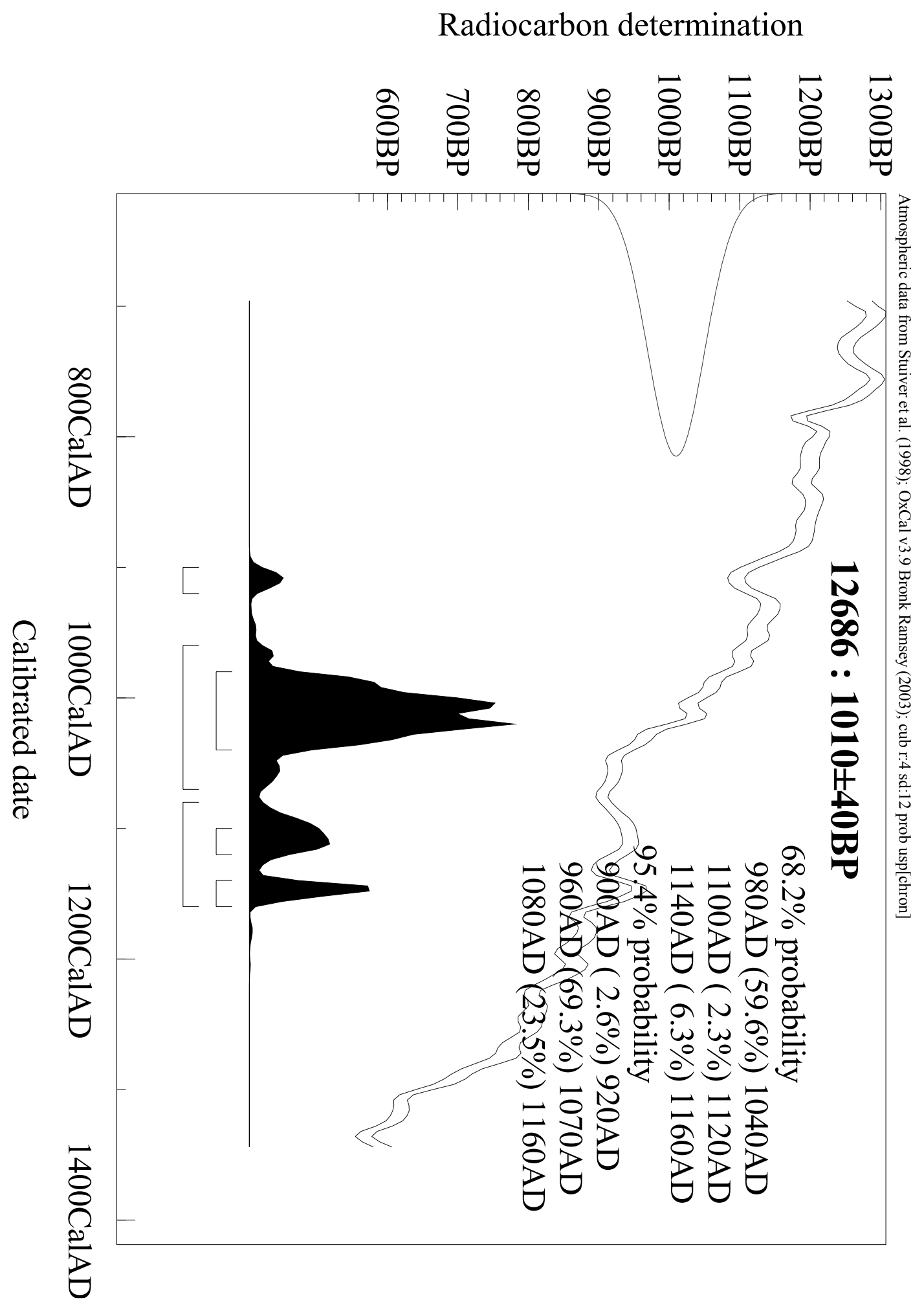




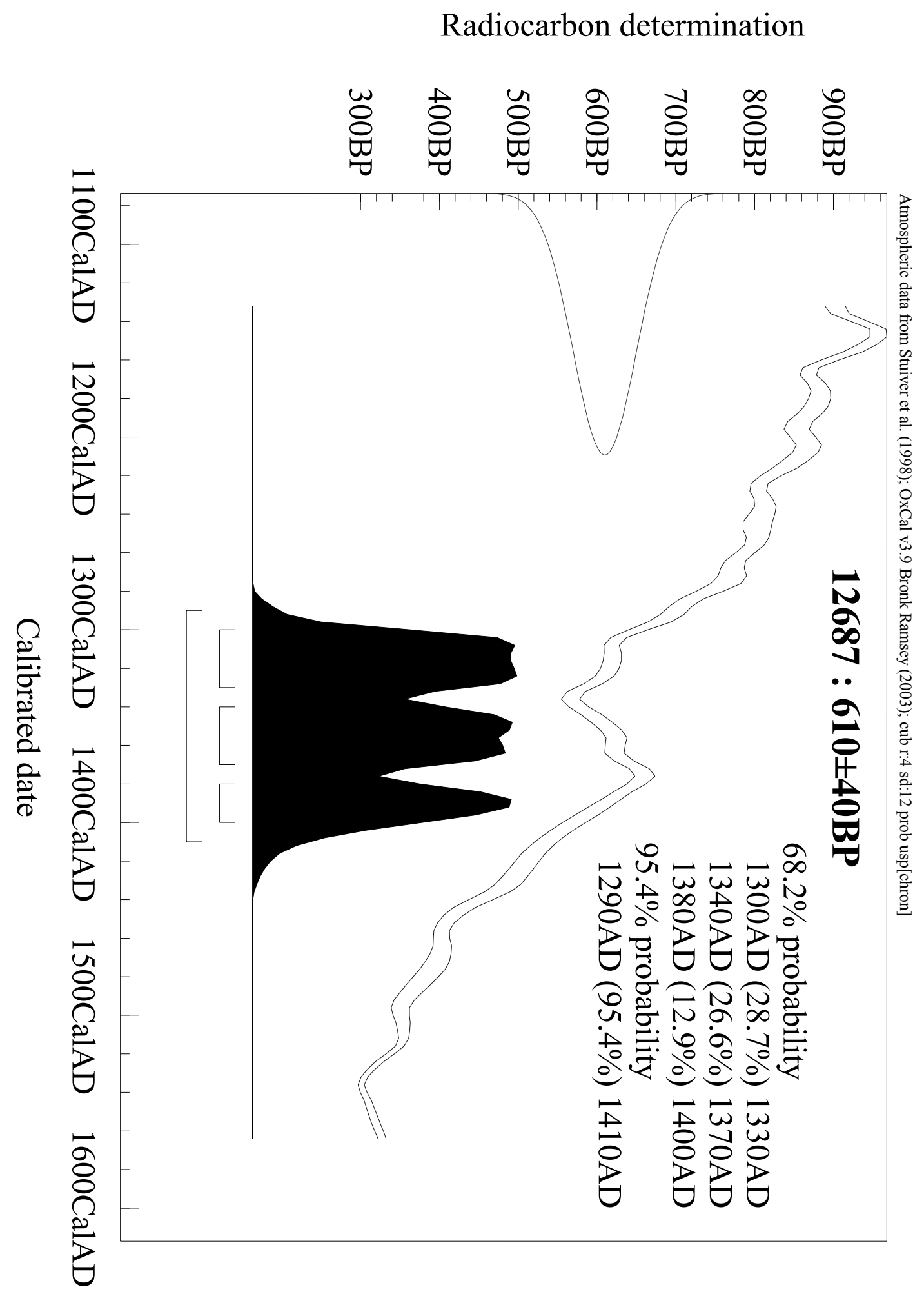




\section{Radiocarbon determination}

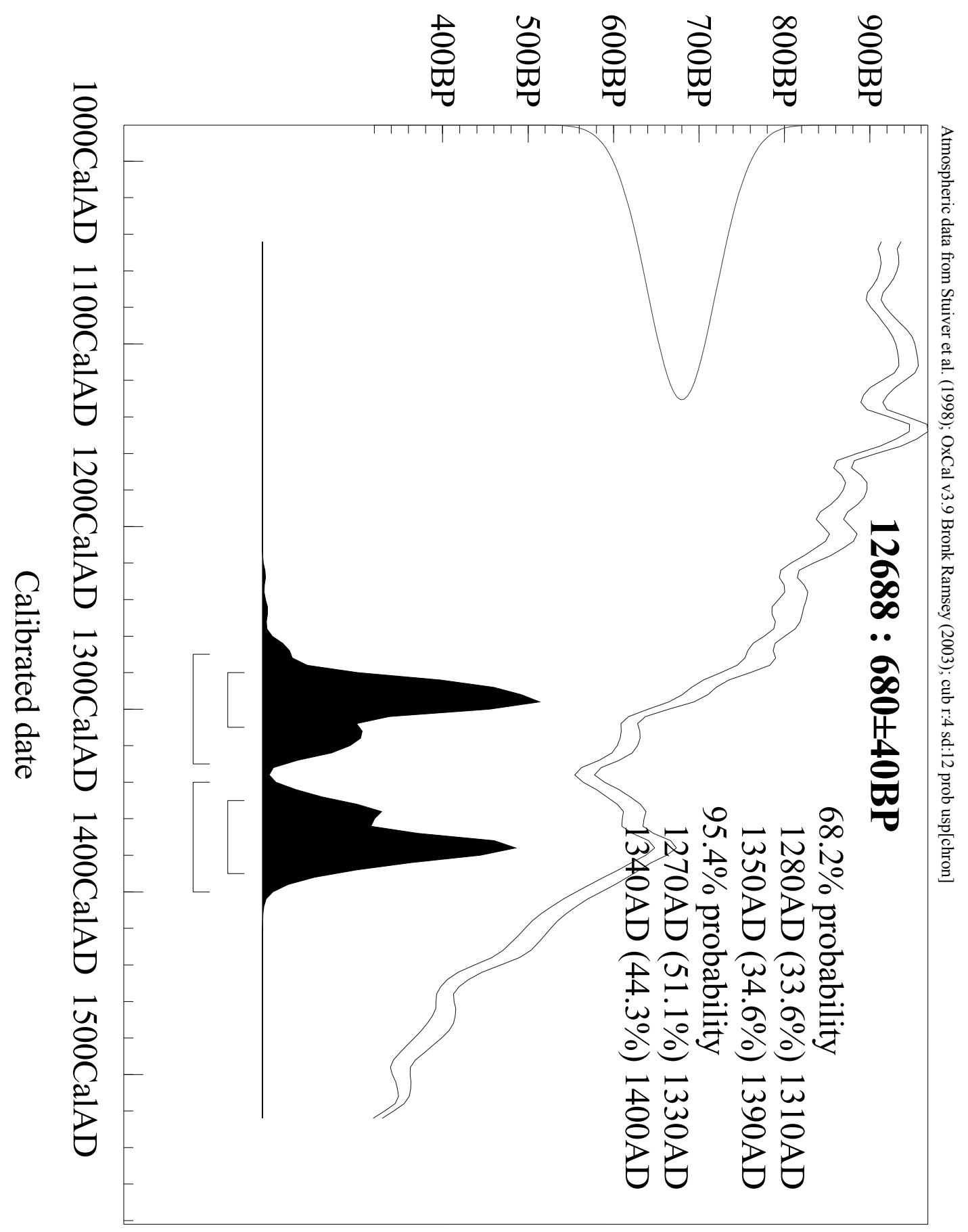




\section{Radiocarbon determination}

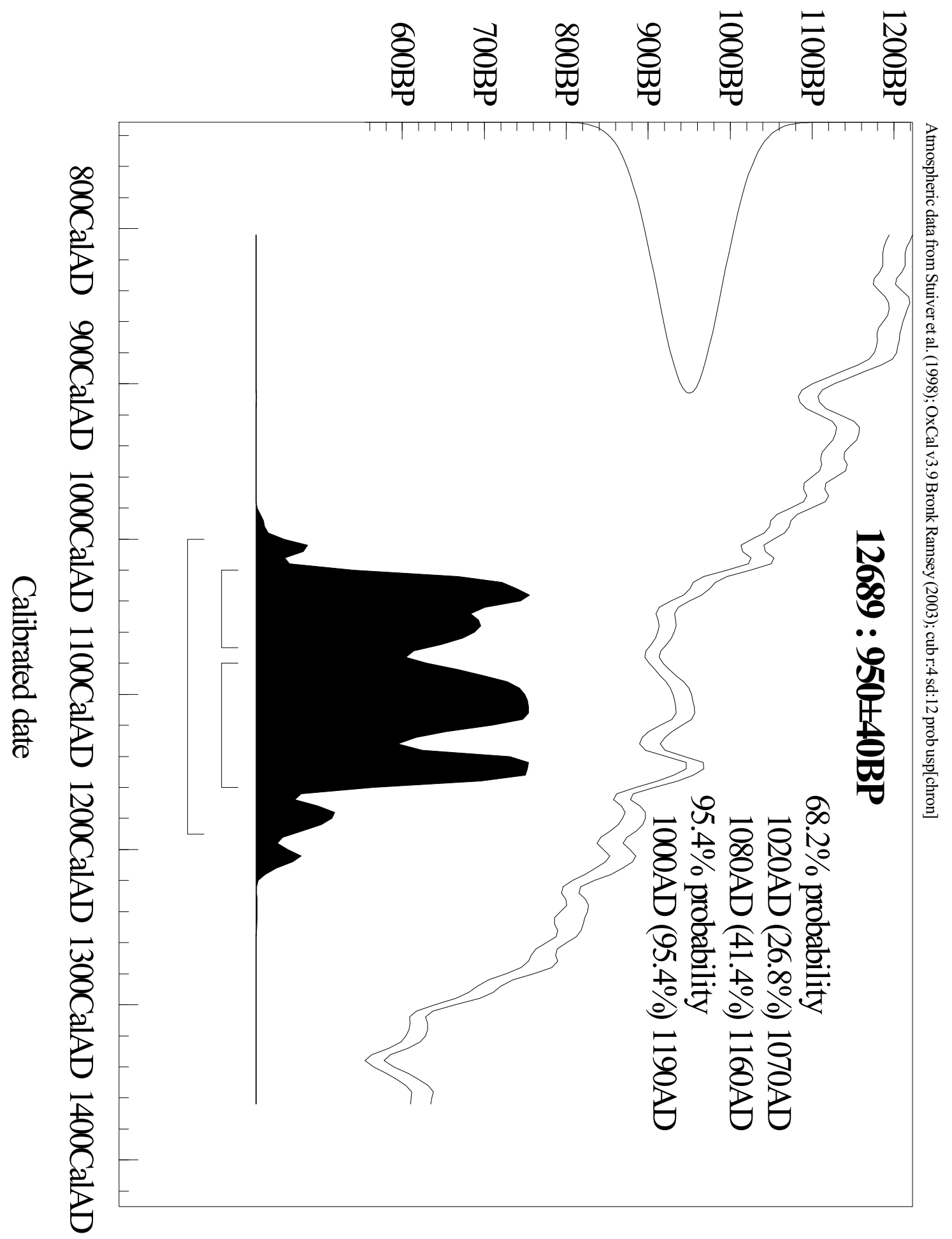




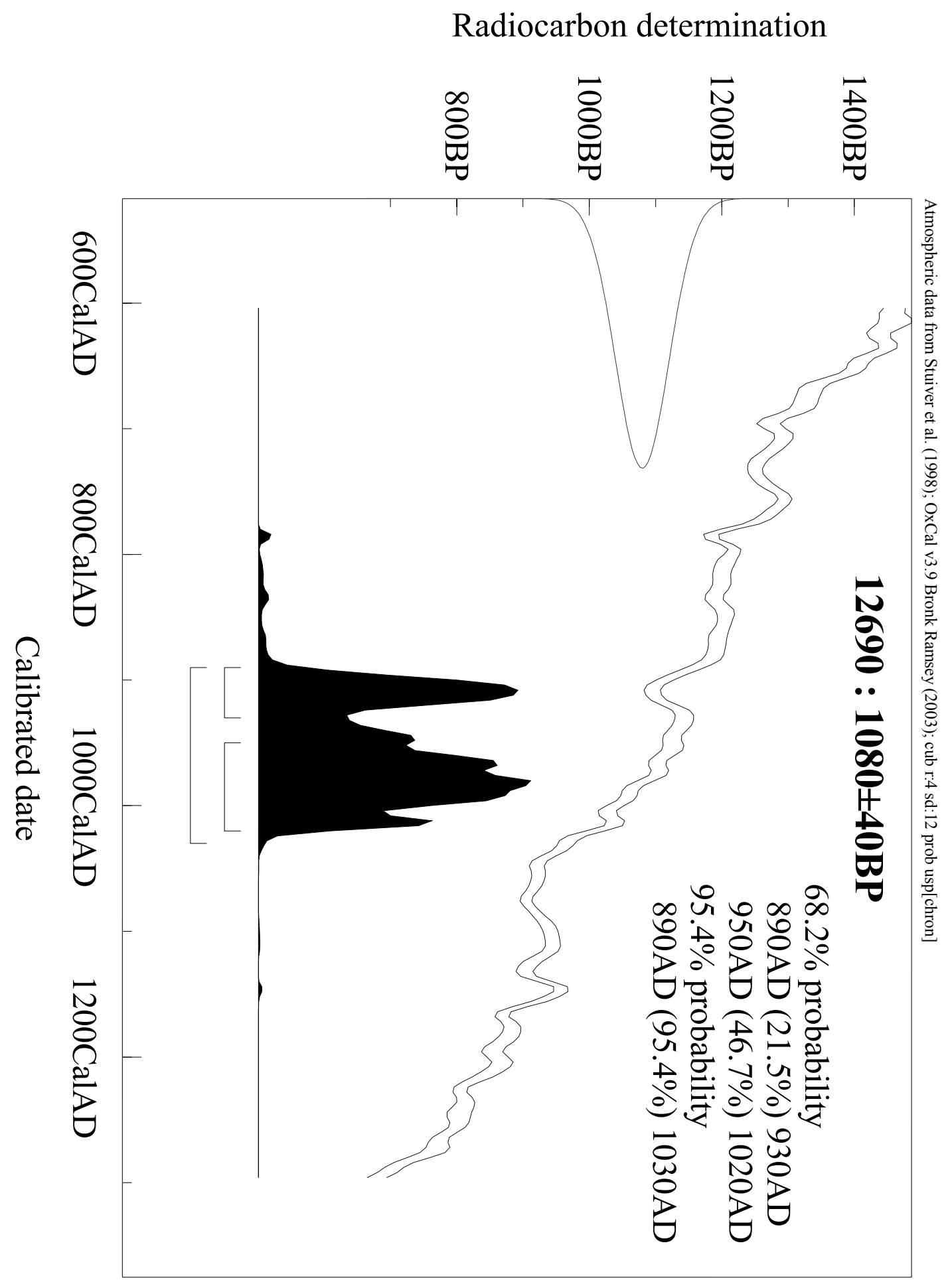




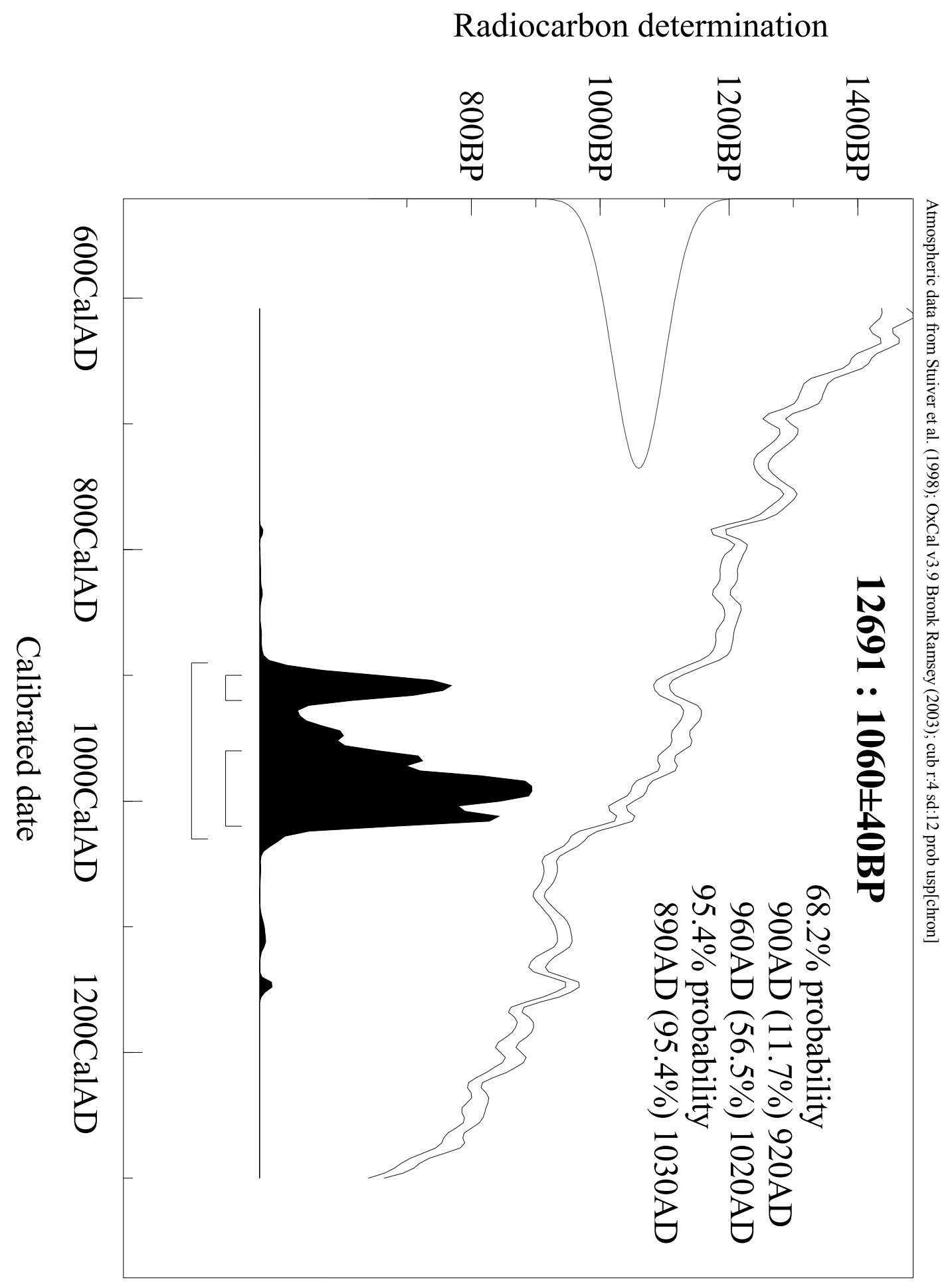




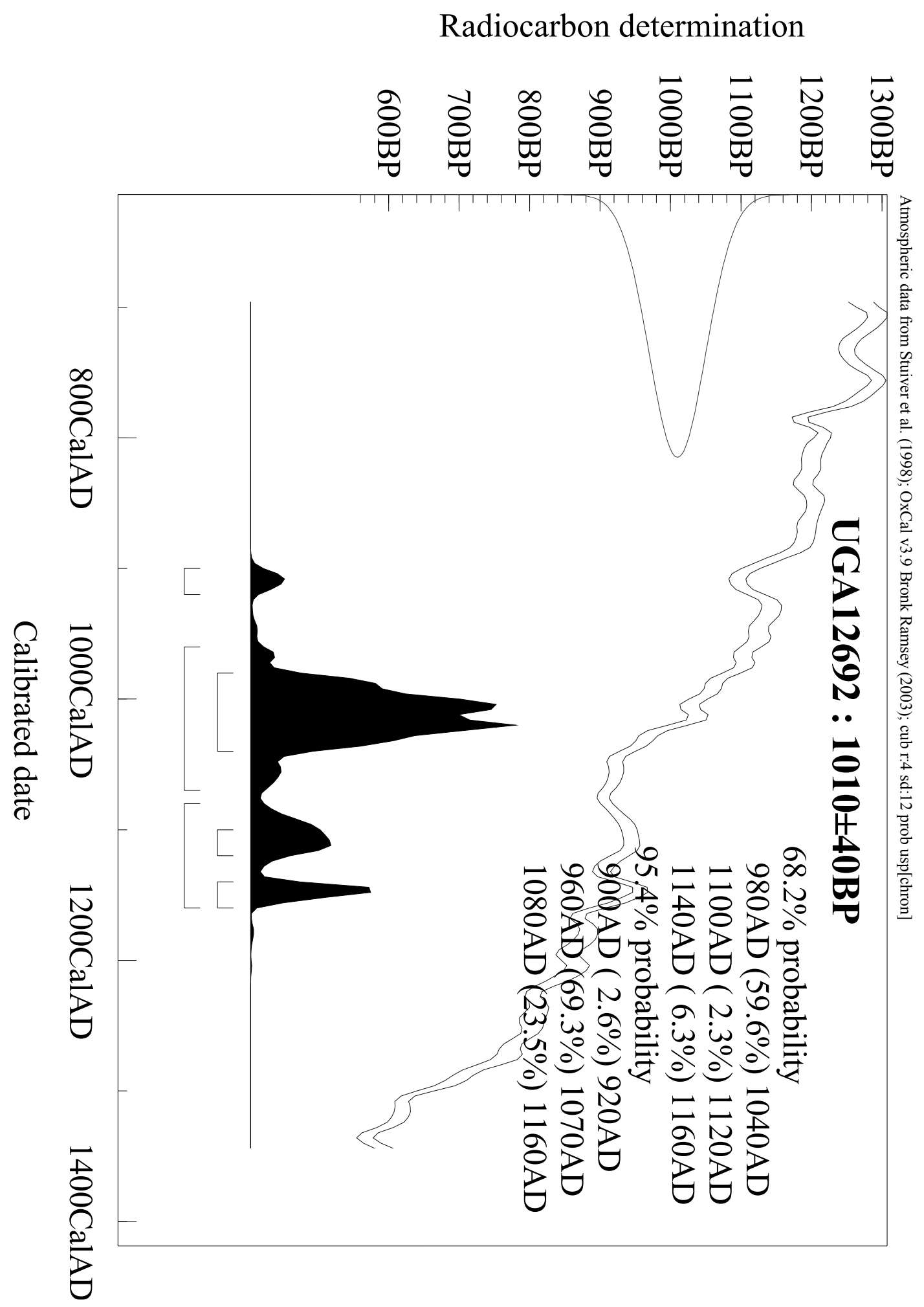




\section{Radiocarbon determination}

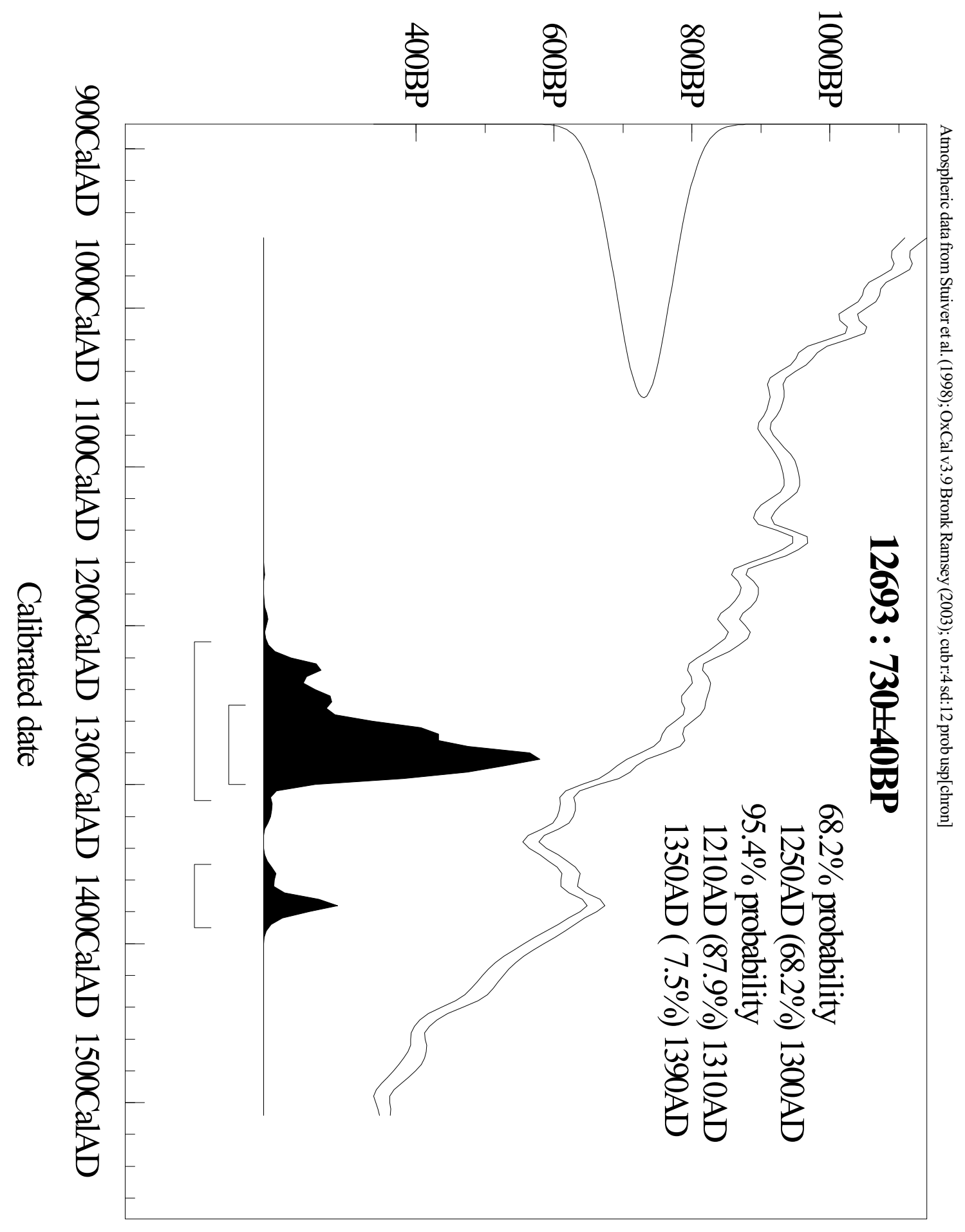




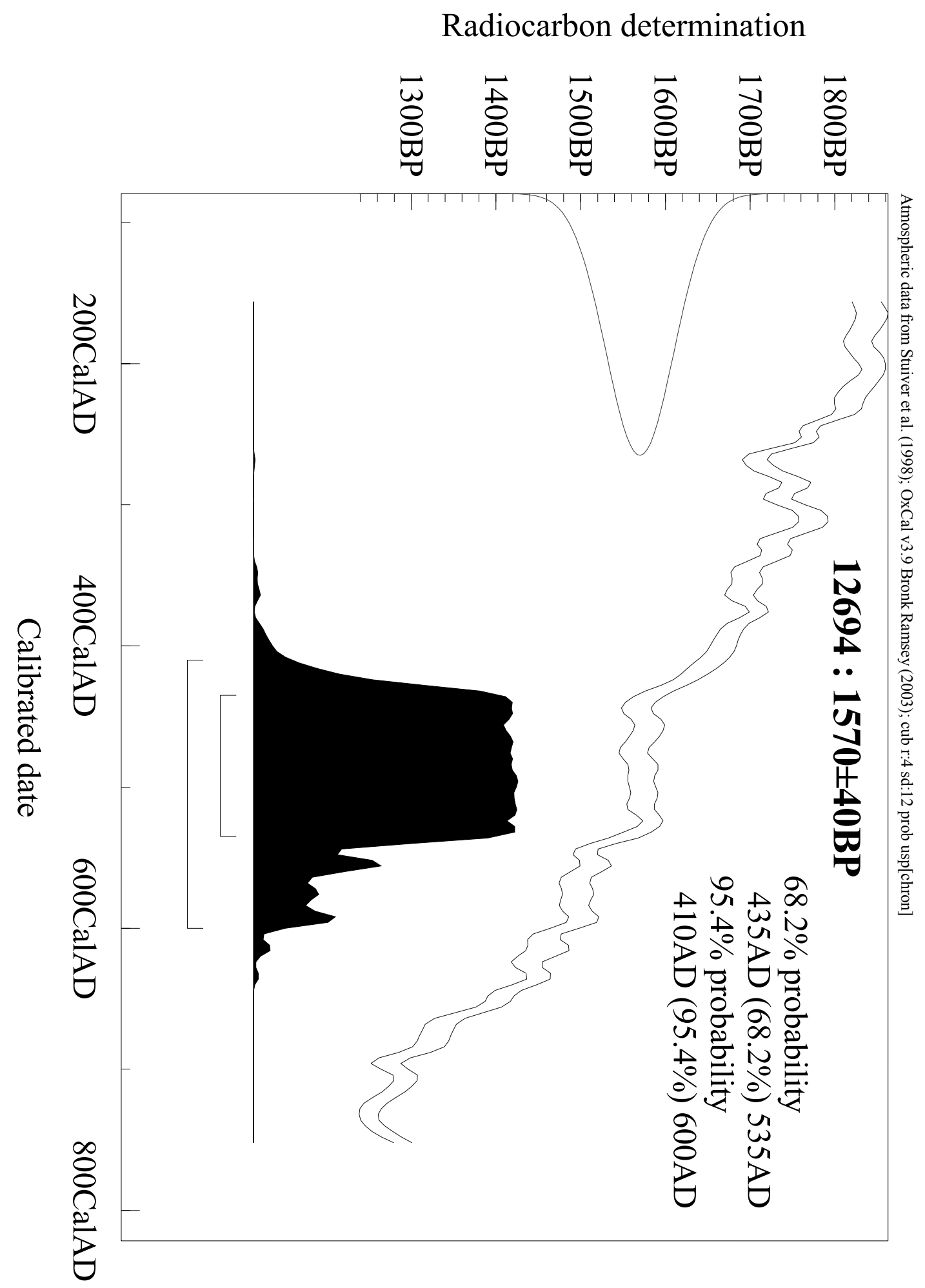




\section{Radiocarbon determination}

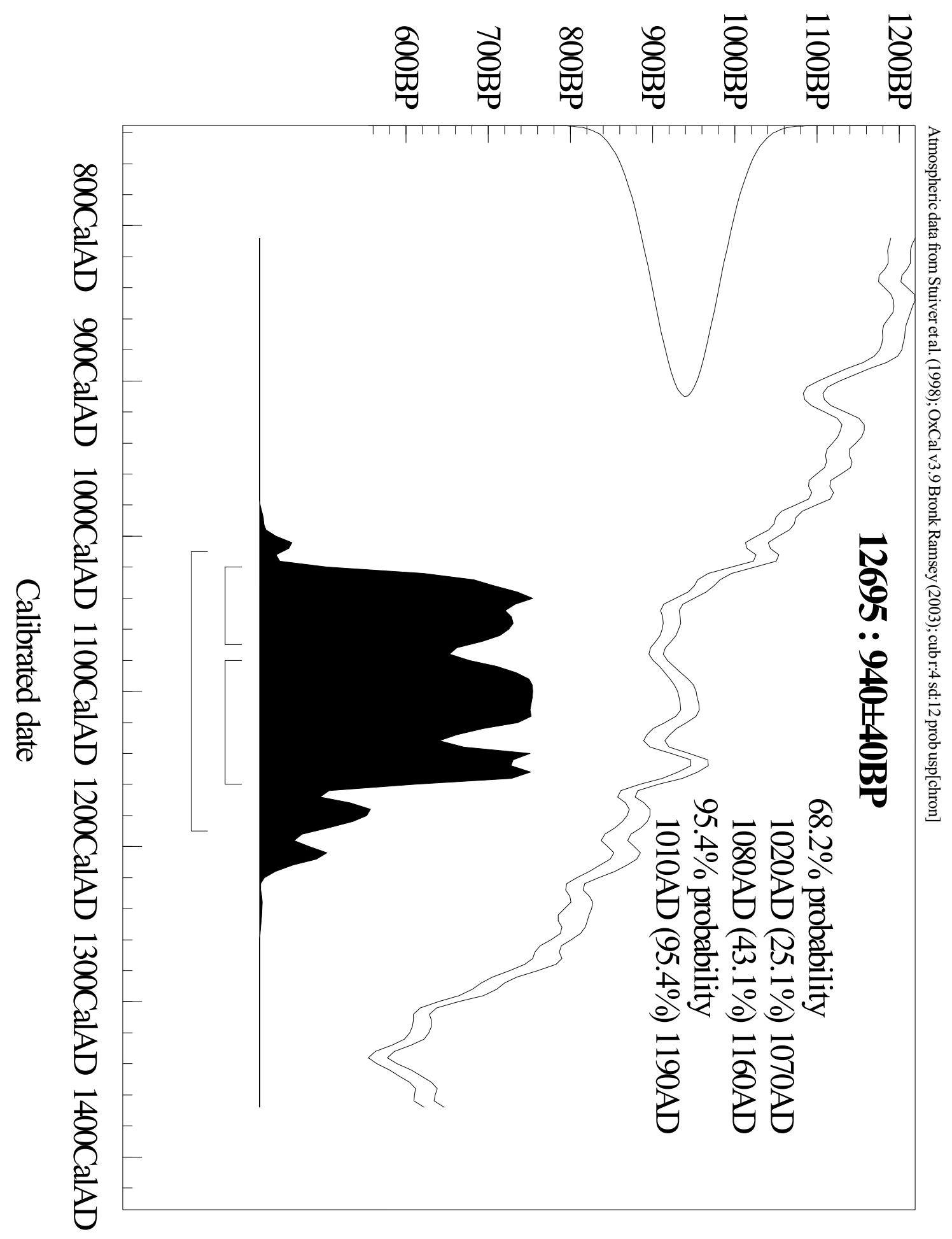


Radiocarbon determination

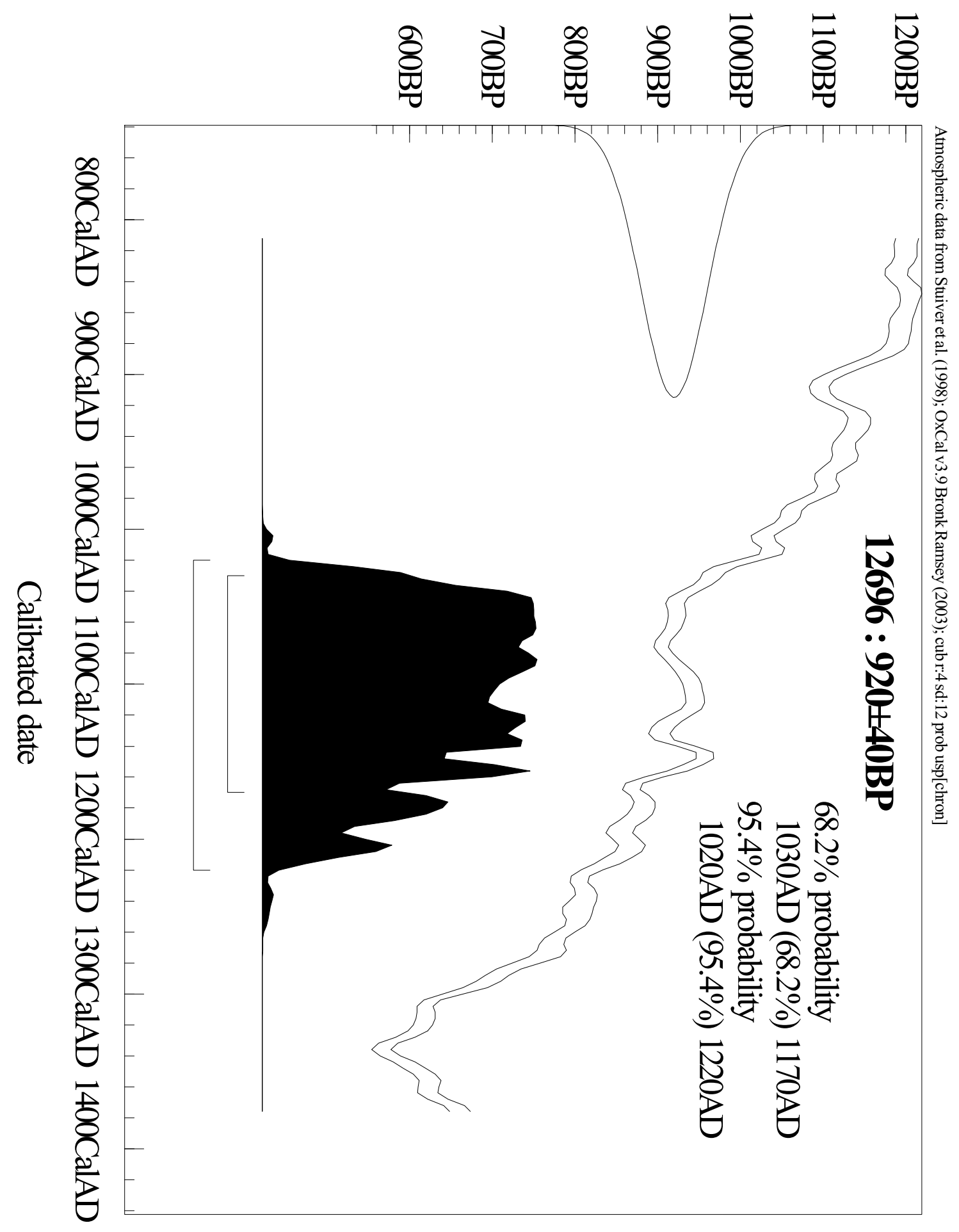

